
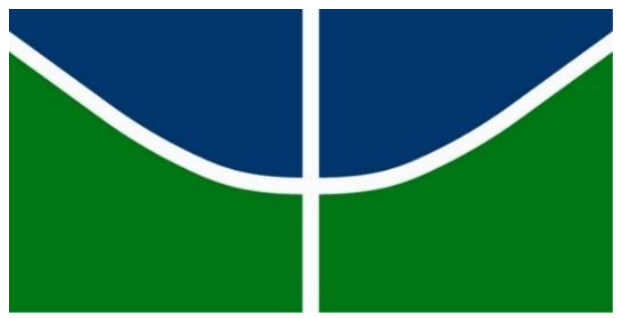

UNIVERSIDADE DE BRASÍLIA

INSTITUTO DE LETRAS

DEPARTAMENTO DE LINGÜÍSTICA, PORTUGUÊS E LÍNGUAS CLÁSSICAS PROGRAMA DE PÓS-GRADUAÇÃO EM LINGUÍSTICA

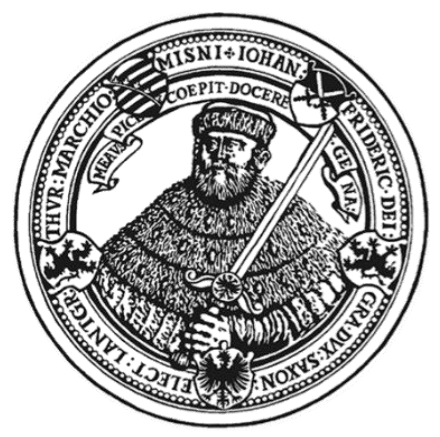

\author{
FRIEDRICH-SCHILLER-UNIVERSITÄT \\ PHILOSOPHISCHE FAKULTÄT \\ INSTITUT FÜR ROMANISTIK
}

\title{
Violência e resistência: representação discursiva da assistência obstétrica no Brasil em relatos de parto e cartas à/ao obstetra
}

\section{Jacqueline Fiuza da Silva Regis}

Tese apresentada em regime de cotutela ao Programa de Pós-Graduação em Linguística, Departamento de Linguística, Português e Línguas Clássicas, Instituto de Letras, Universidade de Brasília (UnB), e à Faculdade de Filosofia da Friedrich-Schiller-Universität Jena (FSU) como requisito parcial para obtenção do Grau de Doutora em Linguística, área de concentração Linguagem e Sociedade, linha de pesquisa Discursos, Representações Sociais e Textos, pela UnB e Doctor philosophiae (Dr. phil.) pela FSU.

Orientadoras:

Claudia Hammerschmidt - Friedrich-Schiller-Universität Jena Viviane de Melo Resende - Universidade de Brasília

Brasília e Jena, dezembro de 2016. 



\title{
Violência e resistência: representação discursiva da assistência obstétrica no Brasil em relatos de parto e cartas à/ao obstetra
}

\author{
Jacqueline Fiuza da Silva Regis
}

Tese apresentada em regime de cotutela ao Programa de Pós-Graduação em Linguística, Departamento de Linguística, Português e Línguas Clássicas, Instituto de Letras, Universidade de Brasília (UnB), e à Faculdade de Filosofia da Friedrich-Schiller-Universität Jena (FSU) como requisito parcial para obtenção do Grau de Doutora em Linguística, área de concentração Linguagem e Sociedade, linha de pesquisa Discursos, Representações Sociais e Textos, pela UnB e Doctor philosophiae (Dr. phil.) pela FSU.

Banca examinadora

Profa. Dra. Viviane de Melo Resende

Universidade de Brasília (UnB) - Presidenta

Profa. Dra. Claudia Hammerschmidt

Friedrich-Schiller-Universität (FSU) - Co-Presidenta

Profa. Dra. Ana Vieira

Quinta Palavra (Botucatu) - Membro efetivo

Profa. Dra. Silvéria Santos

Universidade de Brasília (UnB) - Membro efetivo

Profa. Dra. Juliana Dias

Universidade de Brasília (UnB) - Membro efetivo

Profa. Dra. Viviane Vieira

Universidade de Brasília (UnB) - Membro efetivo

Profa. Dra. Maria Luiza Coroa

Universidade de Brasília (UnB) - Membro suplente 
Fiuza da Silva Regis, Jacqueline

Violência e resistência: representação discursiva da assistência obstétrica no Brasil em relatos de parto e cartas à/ao obstetra / Jacqueline Fiuza da Silva Regis; orientador Viviane de Melo Resende; co orientador Claudia Hammerschmidt. -- Brasília, 2016. $262 \mathrm{p}$.

Tese (Doutorado - Doutorado em Linguística) -Universidade de Brasilia, 2016.

1. Violência obstétrica. 2. Resistência feminina. 3. Humanização do parto e do nascimento. 4. Direitos sexuais e reprodutivos. 5. Análise de Discurso Crítica. I. de Melo Resende, Viviane, orient. II. Hammerschmidt, Claudia, co-orient. III. Título. 
Para Ayumi e Inaê. 

Aviso da Lua que Menstrua

Moço, cuidado com ela!

Há que se ter cautela com esta gente que menstrua... Imagine uma cachoeira às avessas: cada ato que faz, o corpo confessa.

Cuidado, moço

às vezes parece erva, parece hera cuidado com essa gente que gera essa gente que se metamorfoseia metade legível, metade sereia

Barriga cresce, explode humanidades e ainda volta pro lugar que é o mesmo lugar mas é outro lugar, aí é que está: cada palavra dita, antes de dizer, homem, reflita...

$[\ldots]$

E aí quando quer agredir chama de vaca e galinha.

$[\ldots]$

Vaca e galinha..

ora, não ofende. Enaltece, elogia: comparando rainha com rainha óvulo, ovo e leite

pensando que está agredindo que tá falando palavrão imundo.

Tá, não, homem.

Tá citando o princípio do mundo!

(Elisa Lucinda) 



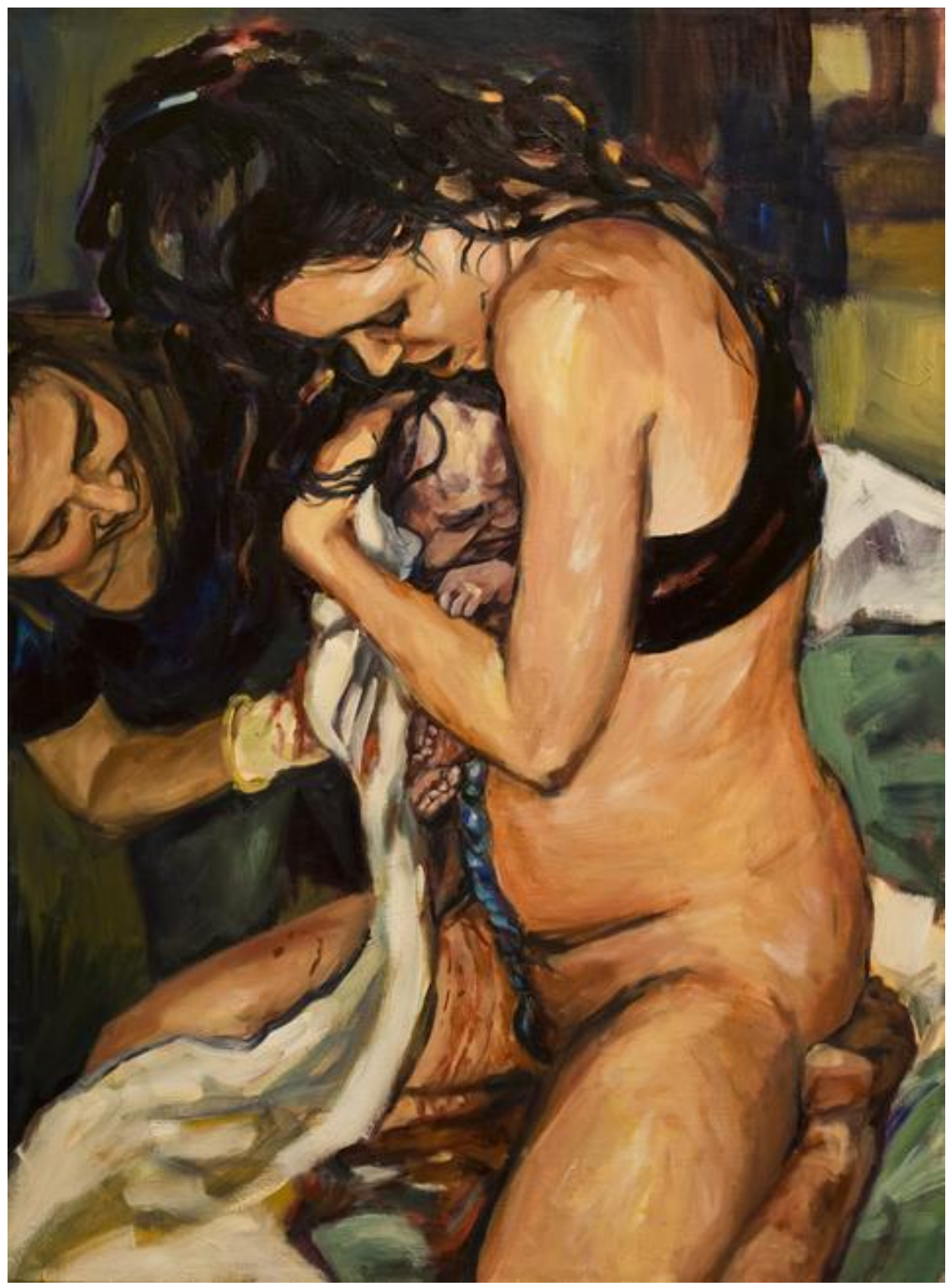

Figura 1 - "O parto", Amanda Greavette, The Birth Project. 



\section{Agradecimentos}

De certa forma, cada leitor, cada leitora, deste livro "escreve" este livro comigo. Pelo menos ela ou ele pensa junto ao ler este livro. Isto também é verdade para a escrita deste livro em si, que tem muitas/os co-autoras/es. Isto aplica-se tanto às/aos autoras/es de todas as obras a que me referi (ver referências), $e$ cujos textos eu já li, sem ser capaz de citar todos aqui, mas também àqueles com quem tenho trabalhado e discutido.

(Siegfried Jäger)

Acho que nunca tive tanto medo de não conseguir um dia finalizar esta tese, quanto tive/tenho medo de não conseguir expressar e comunicar a minha gratidão devidamente. Sei o quão grande é a probabilidade de que eu, pela limitação de minha memória, ou mesmo pela falta de maturidade para o reconhecimento, deixe de agradecer a alguém cuja atuação foi essencial para que eu pudesse hoje apresentar este resultado de minha pesquisa. Portanto, buscando me redimir desse previsível lapso, inicio este agradecimento lembrando que desde que eu nasci, ou mesmo antes disso, inúmeras pessoas contribuíram para que eu chegasse até aqui. O mérito dessa aspirada conclusão é inquestionavelmente comunitário. Por isso, às diversas comunidades e famílias que me acolheram no decorrer da minha vida, sobretudo por meio do empenho de suas mulheres, meu agradecimento primeiro, especialmente a uma de suas principais representantes, a minha tia Maria de Lourdes (in memoriam).

Outra Maria importante em minha trajetória é minha parteira platônica, Silvéria Maria dos Santos, cujo acolhimento no Grupo de Gestantes do HUB, foi essencial para o bom andamento de minhas duas gestações, e para o nascimento também deste trabalho. A você, Sil, agradeço também pelo comadrio e pelas orientações a essa mãe de primeira viagem, pela amorosidade e pelo olhar firme e profundo com que defende o nosso direito de parir em paz e com dignidade.

A Paloma Terra, minha amada parteira, por ser minha prova empírica de que uma assistência obstétrica profissional, respeitosa e amorosa é um sonho possível.

A todas as mulheres que colaboraram generosamente doando suas palavras, em relatos e cartas, sem as quais este trabalho definitivamente não teria sido possível.

À Friedrich-Schiller-Universität e à cidade de Jena, agradeço pela estrutura e pelo esforço em apoiar estudantes com filhas/os para que consigam conciliar a maternidade e as exigências acadêmicas. Além do apoio, por meio da Graduierten-Akademie, para a concretização da cooperação de cotutela. 
À Universidade de Brasília, especialmente à sua Assessoria Internacional, na pessoa de Alício Boaventura, pela prontidão e excelência com que acompanhou e aconselhou todo o longo processo de assinatura do acordo de cotutela para a realização binacional deste doutoramento.

À Coordenação de Aperfeiçoamento de Pessoal de Nível Superior (CAPES), pela bolsa de pós-graduação no âmbito do Plano de Reestruturação e Expansão das Universidades Federais (REUNI), e também pela bolsa para realização de Doutorado Duplo, em cooperação com o Serviço Alemão de Intercâmbio Acadêmico (DAAD), para cumprir a exigência de absolver parte do período da pesquisa na Alemanha.

Ao DAAD, pelo auxílio para estada de pesquisa na Alemanha para doutorandas/os brasileiras/os que possibilitou minha estada para orientação presencial na universidade alemã na fase final de redação desta tese.

A Ana Vieira e Juliana Dias, pela generosa disposição em participar de minha banca de qualificação, quando me presentearam com sua leitura atenta e uma longa discussão com críticas e sugestões valiosas.

A Carla Raiter e a Amanda Greavette, pela cessão das imagens que ilustram este trabalho.

À Escola Waldorf Moara, por ter permitido meu afastamento para a estada de conclusão dos trabalhos em Jena, e a todas/os as/os colegas que generosamente me substituíram enquanto eu estava ausente.

A Melania Amorim, pela colaboração na tentativa de alcançar colaboradoras e pela luta pelos direitos reprodutivos das mulheres.

A minhas/meu colega/s de caminhada Gersiney Pablo Santos, Sinara Bertholdo de Andrade e María Del Pilar Tobar Acosta, por todas as conversas sobre este e outros projetos.

A Carol Lopes Araújo, pela parceria no laboratório de pesquisa, pela instrução e o empréstimo do NVIVO e, é claro, pela comida mexicana.

A Claudia Telschow, pela amizade, pelo apoio na busca de um encontro mútuo entre o jardim de infância alemão e minhas filhas brasileiras, pelo sabor de Holunder em minhas estadas em Jena. 
A Gabriele Wieduwilt, agradeço pelo contagiante sorriso, a simpatia, o apoio, a presença como avó casual e dedicada de minhas filhas, pelas tardes de jardim ou de montanha, pelos passeios, enfim, pelo carinho - mas também por todo o apoio burocrático durante nossas estadas em Jena.

A Annett, Benjamin, Jonathan e Basti, pela amizade, pelo carinho e pelo acolhimento em tantas idas e vindas entre Brasília e Jena.

A Margarete e Siegfried Jäger, por serem meu exemplo vivo de como é possível estabelecer coerência entre teoria e prática e de como definitivamente não é possível realizar pesquisas em ADC sem tomar partido. Por todas as vezes que me acolheram ao me contemplar com seus trabalhos e seu engajamento mesmo antes de enfim nos encontrarmos pessoalmente.

A Hans e Sigrid Barkowski, pela presença, pelo carinho, pelas orientações de toda sorte e pelos deliciosos encontros nas manhãs de domingo.

Meu agradecimento também a minhas queridas orientadoras, Viviane e Claudia, por sempre estarem lá, pela orientação, pela excelência, pelo profissionalismo, mas, sobretudo, pela humanidade, por serem seres humanos exemplares. Aproveito para me desculpar por todas as sugestões valiosas que não fui capaz de incorporar neste trabalho devido a minhas próprias limitações e para agradecer por todos os avanços que só foram possíveis devido a sua dedicação e paciência em todos esses anos de orientação, tantas vezes realizada em condições que me permitiam, com seu apoio, conciliar as tarefas acadêmicas com as exigências da maternidade.

A minha família, stricto e lato sensu, sincrônica e diacronicamente, pela ancestralidade quilombola, pela força de mulheres Anas, Sandras e Marias, em especial,

a minha mãe, pela vida e por tudo que cabe nela, e

a meu pai, pelos momentos em que conseguiu ser pai.

A Ayumi e Inaê, pela honra de poder acompanhá-las desde o primeiro instante de suas vidas, por serem todos os dias a razão maior para eu não desistir de lutar por um mundo melhor para todas as mulheres.

A Glauco, Companheiro, porque a vida a teu lado nos afeiçoa. 



\section{Resumo}

Nesta pesquisa qualitativa, analisei relatos de parto e cartas à/ao obstetra nos quais mulheres abordam suas experiências com a gestação, o parto e a assistência obstétrica, muitas vezes denunciando a violência sofrida nesses eventos e se constituindo, também por isso, enquanto sujeitos de resistência na luta por seus direitos sexuais e reprodutivos. Nesses relatos e cartas é recorrente a menção direta ou indireta à violência obstétrica. Esses documentos são parte de um projeto coletivo com potencial para influenciar o fluxo do 'rio de conhecimento' que é o discurso sobre o parto. Por isso, minha decisão em focar analiticamente esse tipo de documento. O estudo, interdisciplinar pela natureza mesma da questão tratada, foi realizado no âmbito da Análise de Discurso Crítica (ADC) (M. Jäger, 1996; Chouliaraki \& Fairclough, 1999; Fairclough, 2003; Resende, 2009; Ramalho \& Resende, 2011; S. Jäger, 2012), investigando a representação, a identificação e a ação de mulheres no feixe discursivo afeto à gestação e ao parto e, por consequência, à assistência obstétrica. Entre os resultados do estudo, destaca-se o reconhecimento da escrita e da divulgação de relatos de parto e de cartas à/ao obstetra como projetos individuais dentro de uma luta coletiva, na qual mulheres se utilizam dos recursos de que dispõem para comunicar, com teor de manifesto, de conclamação, de convite à resistência, a experiência vivida e a promessa de uma assistência mais digna.

Palavras-chave: violência obstétrica; resistência feminina; humanização do parto e do nascimento; direitos sexuais e reprodutivos; Análise de Discurso Crítica. 



\section{Resumen}

En esta investigación cualitativa, analicé relatos de parto y cartas a las/a los médicas/os obstetras en las cuales las mujeres cuentan sus experiencias durante la gestación, el parto y la atención obstétrica, muchas veces denunciando la violencia sufrida en esos episodios y constituyéndose, por esa razón, en sujetos de resistencia en la lucha por sus derechos sexuales y reproductivos. En esos relatos y cartas es recurrente que se mencione directa o indirectamente la violencia obstétrica. Esos documentos forman parte de un proyecto colectivo con posibilidad de incidir en el flujo del "río del conocimiento" que es el discurso sobre el parto. Por ello, elegí trabajar con esos géneros textuales. El estudio, de carácter interdisciplinario por la misma naturaleza del tema tratado, fue realizado en el ámbito del Análisis Crítico del Discurso (ACD) (M. Jäger, 1996; Chouliaraki \& Fairclough, 1999; Fairclough, 2003; Resende, 2009; Ramalho \& Resende, 2011; S. Jäger, 2012), en el cual investigué la representación, la identificación y la acción de mujeres en el haz discursivo respecto a la gestación, al parto y, en consecuencia, a la asistencia obstétrica. Entre los resultados de la investigación sobresalen el reconocimiento de la escritura y de la divulgación de relatos de parto y de cartas a la/al médica/o obstetra como proyectos individuales que se incluyen en una lucha colectiva en la cual las mujeres disponen sus recursos para comunicar, a manera de manifiesto, de proclama, de invitación a la resistencia, la experiencia vivida y la promesa de una atención obstétrica más digna.

Palabras clave: violencia obstétrica; resistencia femenina; humanización del parto y del nacimiento; derechos sexuales y reproductivos; Análisis Crítico del Discurso. 



\section{Zusammenfassung}

In vorliegendem qualitativen Forschungsprojekt werden Geburtsberichte und Briefe an die Geburtshilfe analysiert, in denen Frauen ihre Erfahrungen mit Schwangerschaft, Geburt und Geburtshilfe diskutieren und oft die Gewalt, die ihnen während dieser Ereignisse widerfahren ist, beklagen. Mit der Verfassung dieser Texte formieren sich die Frauen ferner zu Subjekten des Widerstands gegen diese Gewalt sowie des Kampfes für ihre sexuellen und reproduktiven Rechte. In diesen Dokumenten kommt der Aspekt der Gewalt unter der Geburt immer wieder direkt oder indirekt zur Sprache. Die untersuchten Berichte und Briefe sind Teil eines kollektiven Vorhabens, das vermag, Einfluss auf die Richtung des "Wissensflusses", also den Diskurs über die Geburt, zu nehmen. Die Studie, interdisziplinär allein schon aufgrund der Vielschichtigkeit ihres Themas, wurde im Rahmen der Kritischen Diskursanalyse (KDA) (M. Jäger, 1996; Chouliaraki \& Fairclough, 1999; Fairclough, 2003; Resende, 2009; Ramalho \& Resende, 2011; S. Jäger, 2012) durchgeführt und setzt den Schwerpunkt auf die Untersuchung der Darstellung, Identifizierung und Handlung von Frauen in dem diskursiven Strang, der das Thema Schwangerschaft und Geburt (und damit Geburtshilfe) betrifft. Zu den Ergebnissen der Studie gehört u.a. die Anerkennung dieser Berichte und Briefe als individuelle Vorhaben innerhalb eines kollektiven Kampfes, in dem Frauen die ihnen vorhandenen Ressourcen nutzen, um ihre Erfahrung zu kommunizieren, oft in Form eines Manifests, eines Aufrufs zum Widerstand gegen die Gewalt, aber auch in Form eines Versprechens einer würdigeren Pflege.

Stichwörter: Gewalt unter der Geburt; weiblicher Widerstand; Humanisierung der Geburt(shilfe); sexuelle und reproduktive Rechte; Kritische Diskursanalyse. 



\begin{abstract}
In this qualitative research project, I analyzed written birth stories and letters to the obstetrician in which women discuss their experiences of pregnancy, childbirth and obstetric care, often denouncing the violence suffered during these events, meanwhile constituting themselves also as subjects of resistance in the struggle for their sexual and reproductive rights. These stories and letters often mention obstetric violence. These documents are part of a collective project with the potential to influence the flow of the 'river of knowledge' (M. Jäger, 1996; S. Jäger, 2012) that is discourse on birth. With this intention, I decided to focus analytically on these types of document. This interdisciplinary study was mainly carried out under the Critical Discourse Analysis (CDA) approach (M. Jäger, 1996; Chouliaraki \& Fairclough, 1999; Fairclough, 2003; Resende, 2009; Ramalho \& Resende, 2011; S. Jäger, 2012), investigating the representation, identification and action of women in the discursive strand related to pregnancy and childbirth and therefore to obstetric care. Among the results of the study is the recognition of writing and propagation of these stories and letters as individual projects within a collective struggle in which women use the available resources to communicate their experiences as a manifesto, to call upon resistance and also as a promise for more dignified care.
\end{abstract}

Keywords: obstetric violence; women's resistance; humanization of birth; sexual and reproductive rights; Critical Discourse Analysis. 



\section{Lista de Siglas}

ACGO Colégio Americano de Ginecologia e Obstetrícia

ADC Análise de Discurso Crítica

CAPES Coordenação de Aperfeiçoamento de Pessoal de Nível Superior

CFM Conselho Federal de Medicina

CNPq Conselho Nacional de Desenvolvimento Científico e Tecnológico

Cremerj Conselho Regional de Medicina do Estado do Rio de Janeiro

Cremesp Conselho Regional de Medicina do Estado de São Paulo

DAAD Serviço Alemão de Intercâmbio Acadêmico

DISS Duisburger Institut für Sprach- und Sozialforschung

DLPPE Dicionário de Língua Portuguesa da Porto Editora (2013-2016)

EBC Empresa Brasileira de Comunicação

GO Médica/o especialista em ginecologia e obstetrícia

HUB Hospital Universitário de Brasília

LSF Linguística Sistêmico-Funcional

OMS Organização Mundial da Saúde

PNAC Parto natural após cesárea

PPGL Programa de Pós-graduação em Linguística

RC Realismo Crítico

SUS Sistema Único de Saúde

TP Trabalho de parto

UnB Universidade de Brasília

Unicef Fundo das Nações Unidas para a Infância

VBAC Vaginal birth after cesarean (mesmo que PNAC) 



\section{Lista de figuras e tabelas}

Figura 1 - "O parto", Amanda Greavette, The Birth Project.................................................

Figura 2 - Foto da campanha fotográfica realizada por Carla Raiter, entitulada Violência Obstétrica na Pele, amplamente divulgada nas redes sociais.

Figura 3 - Marcha do Parto em Casa, Salvador (BA), 2012. Fonte: Marcha do Parto em Casa (Facebook)

Figura 4 - Dispositivo e seus componentes. 78

Figura 5 - "Our mouths are filled with laughter, our tongues with songs of joy", obra da artista canadense Amanda Greavette, cujo trabalho, The birth project, também é uma iniciativa promotora de mudanças na representação do parto. 158

Tabela 1- Conceitos comparados, escola britânica e escola alemã. 83 



\section{Sumário}

APRESENTAÇÃO

CAPÍTULO 1 PARIR NO BRASIL NÃO É SÓ UM PARTO. SOBRE A VIOLÊNCIA OBSTÉTRICA E A RESISTÊNCIA DAS MULHERES.

1.1. "A verdadeira dor do parto": a violência obstétrica.

1.2. "Eu tenho me realizado usando minha própria experiência para alertar outras mulheres": a resistência.

1.3. Acontecimentos discursivos. Do parto domiciliar de Sabrina ao parto roubado de Adelir.

\section{CAPÍTULO 2 TRILHAS TEÓRICO-METODOLÓGICAS. TENTANDO ESCREVER} CERTO APESAR DAS LINHAS TORTAS.

2.1. De Jena para Brasília. O Discurso na bagagem e a maternidade no meio do caminho.

2.1.1. Da pesquisa qualitativa e o interesse pelo "mundo lá fora".

2.1.2. Da etnografia à netnografia: do presencial ao virtual.

2.1.3. Inserção da pesquisadora na pesquisa e indicações sociométricas.

2.1.4. Da Análise de Discurso Crítica como possibilidade de pesquisa qualitativa.

2.4. Passos e categorias analíticas.

2.4.1. Análise estrutural, análise fina e análise sinóptica. 
4.1. Análise fina do relato de Tânia. "... uma experiência quase mística, como se eu pudesse, de alguma maneira conhecer uma deusa, sabe?".

4.2. Análise fina do relato de Lívia. "Não, meu medo nunca foi parir".

5.2. Análise fina da carta de Dandara: "Senti a necessidade de compartilhar aqui meus sentimentos". 190 
6.2. Como é representada/identificada a figura da/o profissional da assistência que a acompanha nesse período/momento?

6.4. Como se relacionam essas representações/identificações com a conjuntura mais ampla em que elas acontecem ou das quais elas resultam?

6.5. Como se (re)produz e/ou se minimiza discursivamente o problema da violência obstétrica considerado o contexto mais amplo em que ela se insere?

ANEXOS.

Anexo 1 - nota com comentário de Elena sobre o filme Renascimento do Parto. 



\section{Apresentação}

Falar também é uma forma de ação. Isso é uma aventura. A outra é: começamos alguma coisa. Entretecemos nosso fio numa rede de relações. $O$ que vai sair disso, a gente nunca sabe. [...] Isso vale para todas as ações. E vale de uma maneira muito simples e muito concreta, porque não há como saber. É isso que significa aventura.

(Hannah Arendt)

Durante minha pesquisa de doutorado, analisei relatos de parto e cartas à/ao obstetra nos quais a mulheres abordam suas experiências com a gestação, o parto e a assistência obstétrica, muitas vezes denunciando a violência sofrida nesses eventos e se constituindo, também por isso, enquanto sujeitos de resistência na luta por seus direitos sexuais e reprodutivos.

Nesses relatos e cartas é recorrente a menção direta ou indireta à violência obstétrica que, embora ainda não tipificada legalmente no Brasil, é entendida aqui conforme definido na lei pioneira na América Latina, publicada em 2007 na Venezuela. Nos termos dessa lei, violência obstétrica corresponderia a

a apropriação do corpo e dos processos reprodutivos das mulheres por profissionais da saúde, que se expressa por um tratamento desumanizador, pelo abuso de medicalização e pela patologização dos processos naturais, resultando numa perda da autonomia e da capacidade de decidir livremente sobre seus corpos e sua sexualidade, impactando negativamente a qualidade de vida das mulheres. (Venezuela, 2007)

Onde há violência, há também resistência: Mulheres organizadas em redes horizontais de solidariedade, promovendo a emancipação e o protagonismo feminino, especialmente no diz respeito ao gozo de seus direitos humanos, sexuais e reprodutivos. Essas redes de resistência podem ser entendidas como um projeto identitário coletivo, em prol de um deslocamento hegemônico, nos termos de Gramsci, e da constituição de um lugar subjetivo para a mulher com liberdade de ir e vir sem temer sofrer violência pelo simples fato de ser mulher, com autonomia para decidir livremente sobre intervenções em seu próprio corpo, com direitos humanos, sexuais e reprodutivos garantidos em lei, entre os quais deveria estar o direito à uma assistência obstétrica digna, respeitosa, ética, profissional e humana (ou humanizada).

Nesse contexto, diversos projetos, individuais e coletivos, mudam o fluxo do 'rio de conhecimento' que é o discurso sobre o parto. A escrita e a divulgação de relatos de parto e de 
cartas à/ao obstetra são exemplos desses projetos, quando mulheres se utilizam dos recursos de que dispõem para comunicar, com teor de manifesto, de conclamação, de convite à resistência, a experiência vivida e a promessa de uma assistência mais digna. Por isso, minha decisão em focar analiticamente esse tipo de documento.

O estudo, interdisciplinar pela natureza mesma da questão tratada, foi realizado no âmbito da Análise de Discurso Crítica (ADC) (M. Jäger, 1996; Chouliaraki \& Fairclough, 1999; Fairclough, 2003; Resende, 2009; Ramalho \& Resende, 2011; S. Jäger, 2012), investigando a representação e a identificação de mulheres no feixe discursivo afeto à gestação e ao parto e, por consequência, à assistência obstétrica. Estudos que se filiam à abordagem da ADC, partem necessariamente de uma questão social como motivação para a investigação, cuja perspectiva se furta a uma proposta de neutralidade científica, reconhecendo antes, de forma declarada e transparente, seu engajamento político e o interesse em que do empenho de pesquisa resultem contribuições para a minimização do problema social em questão.

No Capítulo 1, dedico-me a contextualizar a situação da assistência obstétrica no Brasil, apontando aspectos relacionados à violência obstétrica institucional vigente (Aguiar, 2010; Diniz \& Chacham, 2006; Diniz, 2009, Pereira, Franco e Baldin, 2011), assim como a reportar o movimento de mulheres resistentes na luta emancipatória por nossos direitos sexuais e reprodutivos. Essa contextualização é necessária, entre outras coisas, para delimitar o feixe discursivo em foco, ou seja, o recorte temático discursivo a ser estudado. Sobre esse e demais conceitos orientadores da pesquisa discorro no Capítulo 2.

As trilhas teórico-metodológicas percorridas, além de aspectos pontuais de minha biografia que influenciaram a rota da pesquisa, são apresentadas, juntamente com os conceitos e as categorias analíticas, no Capítulo 2 desta tese. Nesse Capítulo, apresento os componentes ontológicos do mundo social como assim os entendo, escrevendo inspirada por Resende (2009), que ajuda a estabelecer pontes, sobretudo entre a ADC da escola britânica (Chouliaraki e Fairclough, 1999; Fairclough, 2003), e o Realismo Crítico (Bhaskar, 1989). Ademais, esse também é o momento em que apresento e justifico minha opção por combinar essas propostas com a ADC da escola de Duisburg (M. Jäger, 1996; S. Jäger, 2012), vertente cujo enquadre metodológico me serviu para a organização da tese como um todo. É ainda no Capítulo 2 que comento a base material e o corpus analítico nos quais se baseia o estudo ora apresentado, além de apresentar sucintamente as mulheres que colaboraram com a pesquisa por meio dos relatos e cartas que escreveram. 
O primeiro passo analítico, a macroanálise ou análise estrutural, como a denomina Margarete Jäger (1996), aparece no Capítulo 3. Nesse momento, os temas abordados estão em primeiro plano e a análise linguística não é realizada em profundidade. Lá comento os subfeixes discursivos mais recorrentes nos relatos e cartas, quais sejam: a autoidentificação; a questão mística ou espiritual no discurso sobre o parto; a necessidade de companhia; a dor o medo e sua concepção plural; uma ressignificação do corpo e de suas exigências no momento do parto; e o convite à resistência, entre outros aspectos.

Nos capítulos 4 e 5, apresento as análises finas, nas quais, conforme a sugestão de M. Jäger (1996), textos considerados exemplares, após a delimitação do feixe discursivo e após a análise estrutural, são, por fim, analisados em profundidade também no que diz respeito às estratégias linguístico-textuais. Para o Capítulo 4, foram selecionados como documentos analíticos dois relatos de parto. Para o Capítulo 5, duas cartas à/ao obstetra.

Concluindo o momento analítico, apresento o Capítulo 6 com uma sinopse das análises antecedentes e organizado de forma a buscar responder, com os resultados das análises prévias, as questões que guiaram meu estudo, pelo menos, desde 2014. Nesse ano, após subsequentes e frequentes revisões e o refinamento das questões iniciais, cheguei àquelas questões como aparecem nesta tese: (1) Como se identificam as mulheres com respeito ao período pré-natal, ao momento do nascimento e ao pós-parto? (2) Como é representada/identificada a figura da/o profissional da assistência que a acompanha nesse período/momento? (3) Como são representados os contextos do pré-natal e do nascimento? (4) Como se relacionam essas representações/identificações com a conjuntura mais ampla em que elas acontecem ou das quais elas resultam? (5) Como se (re)produz e/ou se minimiza discursivamente o problema da violência obstétrica considerado o contexto mais amplo em que ela se insere?

Segue-se a esse capítulo aquele dedicado a algumas considerações, que, apesar de intituladas finais, podem ser consideradas, na realidade, apenas algumas reflexões feitas antes de seguir viagem, pois a principal consideração a ser feita diz respeito às limitações desta tese e à extensão necessária ao engajamento na luta por nossos direitos: toda a vida. 



\section{CAPÍTULO 1 Parir no Brasil não é só um parto. Sobre a violência obstétrica e a resistência das mulheres.}

No Brasil, na assistência ao parto podemos conviver com o pior dos dois mundos: o adoecimento e a morte por falta de tecnologia apropriada, e o adoecimento e a morte por excesso de tecnologia inapropriada.

(Simone Diniz)

Em 2008, durante minha primeira gestação, comecei pela primeira vez na minha vida a me interessar pelas questões relacionadas ao parto, ao nascimento e à assistência obstétrica vigente. Motivada pelo relato de uma amiga querida - que pariu na sala de casa em 2008, numa cidadezinha no interior da Alemanha e que, juntamente com seu companheiro, num dia de reencontro regado a bolo e café, nos relatou o evento com a tranquilidade de quem está relembrando um passeio no parque em um domingo ensolarado -, comecei a pensar em vivenciar eu também um parto não hospitalar. Conversando com outra amiga, já no Brasil, ouvi que algumas mulheres também viviam essa experiência por aqui, algumas até pariam na água. Graças às facilidades da Internet, pus-me a pesquisar sobre o assunto e a me informar sobre as formas possíveis para se parir no Brasil. Desta pesquisa surgiu a informação sobre parteiras em Brasília e sobre uma parteira em particular que acompanhava partos em casa, sob a condição de que a gestante frequentasse um "curso para gestantes", com reuniões semanais realizadas no Hospital Universitário de Brasília. Com sete semanas de gestação e ainda sem barriga alguma, comecei a frequentar esse grupo e a buscar uma "boa hora". E foi assim, bastante sem querer, que acabei chegando ao tema de interesse para realizar minha pesquisa doutoral.

Em 2010, após o primeiro parto, eu queria trabalhar para divulgar o parto natural e condenar a cesárea, para que mais mulheres pudessem vivenciar o parto como um belo passeio num dia ensolarado. Àquela altura, eu ainda não tinha tanta clareza sobre o problema que impedia mais mulheres de vivenciarem isso, acreditava que a culpa era provavelmente do número elevado de cesáreas. Seis anos mais tarde, e um tanto menos ingênua que àquela época, percebo que as coisas não são simples e que a elevada taxa de cesáreas não é, por si só, o maior empecilho no caminho das mulheres que querem parir com dignidade. Essa taxa é antes uma consequência de um problema maior que atinge as mulheres e que embarca as cesáreas desnecessárias e indesejadas: a violência obstétrica. Violência essa que também tem seu aspecto discursivo, que poderia, quiçá, mesmo ser chamado violência discursiva. 
1.1. "A verdadeira dor do parto": a violência obstétrica.

As pesquisas em Análise de Discurso Crítica (ADC) têm como ponto de partida e motivação um problema social e, como objetivo final, contribuir de algum modo para a mitigação desse mesmo problema (M. Jäger, 1996; Chouliaraki \& Fairclough, 1999; Fairclough, 2003; Resende e Ramalho, 2006; Resende, 2009; Ramalho \& Resende, 2011; S. Jäger, 2012). No caso da pesquisa em pauta, o problema é justamente a violência obstétrica existente no país. O trabalho de Aguiar (2010), Violência institucional em maternidades públicas: hostilidade ao invés de acolhimento como uma questão de gênero, enfatizou esse aspecto problemático do nascimento no Brasil, argumentando que isso diz respeito não apenas às elevadas taxas de cesáreas, mas também a outras formas de violência contra a mulher no momento do parto.

No mesmo ano em que Aguiar publicou seu estudo, em 2010, foi realizada pela Fundação Perseu Abramo uma pesquisa intitulada Mulheres brasileiras e gênero nos espaços público e privado, para a qual foram entrevistadas 2.365 mulheres e 1.181 homens, em 25 Unidades da Federação, em mais de 170 municípios urbanos e rurais. A pesquisa foi realizada por meio de entrevistas pessoais e domiciliares, com questionário estruturado, por equipes compostas por pesquisadoras nas entrevistas com mulheres, e por pesquisadores nas entrevistas com homens.

Para abordar especificamente a questão da violência obstétrica, foi feito o seguinte pedido às mulheres: Vou falar algumas coisas que podem acontecer no atendimento ao parto e gostaria que você dissesse se aconteceram ou não com você. Na hora do parto, algum profissional no serviço de assistência: Fez o exame de toque de forma dolorosa? Negou ou deixou de oferecer algum tipo de alivio para a sua dor? Gritou com você? Não te informou sobre algum procedimento que estava fazendo? Se negou a te atender? Te xingou ou te humilhou? Te empurrou? Te amarrou? Bateu em você? Assediou você sexualmente? E o resultado obtido foi a declaração, por parte de $25 \%$ das entrevistadas, de que, sim, havia sofrido alguma dessas formas de violência, e 23\% ouviu comentários como: (a) Não chora não que ano que vem você está aqui de novo; (b) Na hora de fazer não chorou/ não chamou a mamãe, por que está chorando agora? (c) Se gritar, eu paro agora o que eu estou fazendo, não vou te atender. (d) Se ficar gritando, vai fazer mal pro seu neném, seu neném vai nascer surdo.

No dia 8 de março de 2012, por ocasião do Dia Internacional da Mulher, Ligia Moreiras Sena, Fernanda Andrade Café e Ana Carolina Arruda Franzon, numa ação de ciberativismo, realizam o Teste da violência obstétrica, com um questionário de múltipla escolha divulgado 
coletivamente por cerca de 75 blogs e respondido por cerca de duas mil mulheres, resultando na avaliação de 1966 nascimentos. Na postagem Violência obstétrica é violência contra a mulher, datada de 20 de junho de 2012, Ligia Moreiras Sena comenta os resultados desse estudo: ${ }^{1}$

Desse número total, quase a metade das mulheres relataram terem sido vítimas de uma forma de violência; menos da metade se sentiu segura durante seu parto; 356 mulheres se sentiram ameaçadas pela equipe de saúde; 466 tiveram seu períneo cortado; 420 não puderam se movimentar, mesmo querendo; o médico ou o enfermeiro subiu em cima da barriga de 382 mulheres, para empurrar o bebê para baixo; e 1.029 mulheres não puderam segurar seus filhos no colo depois do nascimento... De todas essas mulheres, 615 sentiram-se frustradas por não terem tido o parto como haviam sonhado e 331 sentiram raiva logo após o nascimento dos seus bebês por terem sido mal atendidas.

O contexto brasileiro tem a violência obstétrica marcada igualmente em seus altíssimos índices de cesáreas. Mais de 50\% dos nascimentos no Brasil (Batalha, 2012; Brasil, 2012) acontecem por intervenções cirúrgicas, cuja necessidade, ou embasamento médico-científico, é questionável, extrapolando sobremaneira o limite de 15\% preconizado pela Organização Mundial da Saúde (Lauer et al., 2010). Ressalte-se que diversos especialistas, como, por exemplo, Souza, Amorim \& Porto (2010), em seu artigo "Condições frequentemente associadas com cesariana, sem respaldo científico", asseguram serem poucos os possíveis benefícios de uma cesariana, cirurgia associada a maior mortalidade materna que o parto vaginal, e também a um aumento de morbidade e mortalidade entre recém-nascidas/os. Como bem resumiu Gonçalves (2014, p. 57):

Entre os problemas decorrentes do excesso de cesarianas para as crianças estão: prematuridade (nascimentos com menos de 37 semanas), desenvolvimento de problemas respiratórios, baixo peso, maior probabilidade de recorrer a UTI neonatal (caso a cirurgia seja feita antes das 37 semanas de gestação). Para as mães alguns dos problemas são: maior risco de necessidade de internação em UTI, de transfusão sanguínea, de uso de antibióticos, dificuldades na amamentação, recuperação mais lenta. A cirurgia, quando eletiva, ainda gera mais custos do que o parto vaginal, o que na rede pública gera mais despesas, mas nas instituições privadas pode gerar mais lucro.

Ademais é intrigante e instigante tentar entender e encontrar soluções diante do que a pesquisadora Simone Diniz (2009, p. 313) denomina "paradoxo perinatal", o fato de ter-se 
verificado nas duas décadas que antecedem a publicação de seu artigo, "uma melhoria de praticamente todos os indicadores da saúde materna no Brasil, assim como grande ampliação do acesso aos serviços de saúde", sem que, contudo, houvesse uma redução nos índices de mortalidade materna.

Embora este estudo se atenha ao contexto brasileiro, a questão da violência obstétrica é internacional, atingindo mulheres também em outros países do mundo, como, por exemplo, a Venezuela, país pioneiro em definir legalmente a violência obstétrica (Venezuela, 2007), tipificação ainda inexistente no Brasil. Na legislação venezuelana, violência obstétrica é

a apropriação do corpo e dos processos reprodutivos das mulheres por profissionais da saúde, que se expressa por um tratamento desumanizador, pelo abuso de medicalização e pela patologização dos processos naturais, resultando numa perda da autonomia e da capacidade de decidir livremente sobre seus corpos e sua sexualidade, impactando negativamente a qualidade de vida das mulheres.

Na América Latina, mais ao norte, temos também o caso do México, cujas taxas de cesarianas também ultrapassam 50\% dos nascimentos. O sociólogo Roberto de Castro - apoiando-se em estudos realizados sobre a qualidade nos serviços de saúde pública (Jiménez-Corona et al., 2006; Peña, Rodríguez y López, 2004; Valdés, Molina y Solís, 2001 apud Castro, 2014, p. 169), estudos qualitativos com base em relatos e denúncias individuais sobre a violência sofrida durante o atendimento por parte de pessoal médico (Cruz, 2000 apud Castro, 2014, p. 169), assim como em notícias de casos judiciais onde as mulheres tenham ganhado a causa após a denúncia do caso de violência - sugere que haja um habitus médico autoritário no México, que nas escolas de medicina, à semelhança de instituições militares, por meio de castigos como recurso didático, desigualdades de gênero e hierarquias profissionais, formaria suas/seus estudantes para a violência institucional também na atenção obstétrica. Esse quadro o leva a defender que o fim das violações dos direitos humanos das mulheres nos serviços de saúde deve passar necessariamente por uma radical reestruturação do campo médico. Citando dados de Fajardo-Dolci et al. (2009), Castro (2014, p. 168) relembra que a Comissão Nacional de Arbitragem Médica do México aponta a gineco-obstetrícia como a especialidade a receber o maior número de queixas de vítimas de violação de direitos. Ele nos conta que

Nos últimos 25 anos vêm se acumulando evidências em vários países da América Latina demonstrando que os serviços de saúde, em particular os de saúde reprodutiva, constituem mais um lugar em que se exerce a violência contra as mulheres. Internacionalmente têm-se realizado estudos que 
recolheram o testemunho de mulheres sobre a sua experiência nos serviços de saúde durante o parto, e nos quais fica claro que muitas delas foram maltratadas, humilhadas, intimidadas ou abusadas (Asowa-Omorodion, 1997; Grossmann-Kendall et al, 2001).

Felizmente, em 2014, seguindo os passos da Venezuela e da Argentina, o México também tipificou legalmente a violência obstétrica.

Observando o contexto europeu, e mostrando que o problema não se restringe à América Latina, temos o trabalho de Marjorie Tew, que, ainda em 1990, escreveu uma história crítica da assistência obstétrica na Grã-Bretanha, o livro intitulado Safer Childbirth? Nesse livro, a autora questiona a validade da hospitalização, da medicalização do parto e do nascimento, considerando-se que as taxas de mortalidade materna e neonatal também não diminuíram com saída do parto do ambiente domiciliar para o institucional. Desde a década de 1980, quando se pode dizer que a sociedade britânica já considerava o nascimento como sendo um evento médico-hospitalar, nutrindo o que ela chama de "popular misconception about the power of doctors" $"$ as taxas não se alteraram. Tew, já àquela época, ressalta que essa realidade também é verdadeira para outras sociedades. Embora ela não mencione o Brasil, poderia tê-lo feito com adequação. Segundo ela, todos os países industrializados haviam presenciado, nos cinquenta anos anteriores à publicação do livro, tanto uma melhora momentânea da segurança do parto quanto a consumação de uma revolução momentânea na assistência obstétrica, com o triunfo da filosofia e dos métodos da obstetrícia, embora já àquela altura houvesse evidências de que a intervenção obstétrica raramente melhorasse o processo natural (Tew, 1990, p. vii). Ela afirma, ainda, que essas evidências são encontradas em

análises estatísticas imparciais dos resultados reais da atenção obstétrica, que mostram de forma consistente que o nascimento é tão mais seguro, quanto menos se interfira no seu processo. Os resultados das estatísticas estão em completo acordo com as expectativas da biologia e são, por sua vez, confirmados, de maneira impressionante, pelas observações de obstetras críticos, na avaliação de determinadas práticas.

Essas análises demonstravam, ainda, que a estatística, surpreendentemente, não confirmava a ideia tão presente no senso comum, de que a progressiva hospitalização do parto tivesse provocado o declínio alcançado nas taxas de mortalidade materno-infantil, alcançado, na

2 "Ilusão popular sobre o poder dos médicos". 
realidade, graças a eficazes políticas públicas de saúde coletiva e de engenharia sanitária (Tew, 1990, p. viii).

Entre os países industrializados, a Holanda era, já em 1990, e ainda é, uma das grandes exceções a essa onda de medicalização e hospitalização do parto, sendo, por isso mesmo, um modelo de boa prática obstétrica.

Entre os países com menor intervenção médica na atenção ao parto, a Holanda é destaque por sua reduzida taxa de cesárea comparada aos demais países desenvolvidos. Nesse país, a freqüência de intervenções médicas é pequena e cerca de $30 \%$ dos partos de baixo risco ocorrem no domicílio da gestante. A assistência obstétrica é realizada por parteiras que, quando suspeitam que poderá haver complicações no parto, encaminham a parturiente para o hospital. O modelo holandês tem sido usado para indicar que a assistência ao parto fora do hospital e efetuada por parteiras traz bons resultados. (Kwee et al. 2004 apud Patah \& Malik, 2011, p. 190)

A Alemanha, sua vizinha, apesar de ainda ter um sistema que conta institucionalmente com a assistência realizada por parteiras, tem apresentado, atualmente, uma elevação nos índices de cesarianas e uma grave crise nas condições de trabalho das parteiras, que trabalham como profissionais liberais, fazendo com que a qualidade na assistência seja comprometida e a violência obstétrica aumente. Sobre essa violência, Christina Mundlos (2015) escreve o livro intitulado Violência no Parto: o escândalo cotidiano, com base em relatos sobre as experiências de mães e parteiras, com cesarianas desnecessárias, a mutilação genital não autorizada, a rotina de toques vaginais doloridos e desnecessários, a recusa em conceder analgesia e mulheres sendo atadas, deixadas sozinhas, sendo ridicularizadas e insultadas.

Voltando ao contexto brasileiro, não há no país a tipificação legal da violência obstétrica, embora haja legislação voltada a garantir um atendimento obstétrico que não viole os direitos sexuais e reprodutivos das mulheres, como, por exemplo, a Portaria Ministerial 569, de 2000, que institui o Programa de Humanização no Pré-natal e Nascimento, no âmbito do Sistema Único de Saúde (SUS); ou a Portaria 1.067, de 2005, que institui a Política Nacional de Atenção Obstétrica e Neonatal, no âmbito do SUS; além da Lei 11.108, de 2005, que garante à mulher parturiente o direito à presença de acompanhante durante o trabalho de parto, parto e pós-parto imediato, no âmbito do SUS. Entretanto, essas e outras regulamentações não têm sido suficientes para garantir os direitos sexuais e reprodutivos das mulheres, por isso mesmo, outras propostas legislativas foram apresentadas, como o Projeto de Lei ${ }^{\circ} 8$, de 2013 , apresentado ao Senado Federal com o objetivo de incluir a obrigatoriedade de obediência às diretrizes e 
orientações técnicas e o oferecimento de condições que possibilitem a ocorrência do parto humanizado nos estabelecimentos de saúde do SUS; o Projeto de Lei, n 75, de 2012, que visa a estabelecer a assistência à saúde integral, promovida pelo Poder Público, à presa gestante, bem como vedar a utilização de algemas em mulheres em trabalho de parto; além do Projeto de Lei 7.633, de 2014, que dispõe sobre a humanização da assistência à mulher e ao neonato durante o ciclo gravídico-puerperal, apresentado à Câmara Federal pelo Deputado Jean Wyllys, atendendo a reinvindicações de coletivos de mulheres para transformar as normas ministeriais em Lei Federal, garantindo assim maior eficácia no seu cumprimento.

Como lembra a historiadora Maria Lúcia Mott (2002, p. 207), em 1945, 70,4\% dos partos do maior município do Brasil, o município de São Paulo, ainda aconteciam em casa. Segundo essa autora (2002, p. 198),

a indicação do hospital como lugar ideal e seguro para as mulheres darem à luz é uma recomendação que passa a ser divulgada na literatura médica, com mais ênfase, a partir da década de 1930. Até o final do século XIX, os partos eram realizados quase que exclusivamente no domicílio da parturiente [...] assistidos na maioria das vezes por parteira leiga e raramente por parteira diplomada. Apenas em casos complicados, quando a parteira não conseguia resolver o problema, chamava-se o médico.

$[\ldots]$

Dar à luz fora de casa era uma situação anormal, considerada apavorante e procurada apenas em casos extremos, sobretudo por pessoas tidas como desclassificadas socialmente.

Embora a hospitalização não seja uma exclusividade vivida pelas mulheres em trabalho de parto, mas sim algo mais amplo referente à hospitalização do corpo patologizado de maneira sem precedentes no mundo ocidental, num movimento que, de acordo com Foucault (2012), em sua obra Nascimento da clínica, ocorreu paulatinamente desde o final do século XVIII, há que se perguntar sobre as especificidades do evento do parto que viabilizaram ou foram instrumentadas a fim de levar a cabo a sua hospitalização, quando ainda na primeira metade do século XX, aumentou o número de médicos que acompanham o parto, encarado e propagado, cada vez mais, como um evento médico e potencialmente perigoso. Tornquist (2004, p. 72) observa que:

Centradas, inicialmente, em uma visão bastante pessimista da natureza feminina, a obstetrícia e a ginecologia justificarão [sic.] toda uma série de inovações científicas - particularmente no campo da cirurgia - que tornaram a mulher um corpo passivo. Os instrumentos e as técnicas obstétricas, criados e usados no campo da medicina da mulher, são reveladores desta visão, ao mesmo tempo em que estão carregados de associações com a sexualidade e a ascendência dos homens sobre as mulheres ou, neste caso, dos médicos sobre 
suas pacientes. Embora, no século XX, o corpo feminino tenha adquirido [apenas legalmente e não em todo o mundo] um estatuto de simetria em relação ao corpo masculino, ele não deixou de ser visto em uma posição de assimetria e englobamento pelo masculino.

O desenvolvimento técnico da obstetrícia e da indústria farmacêutica, e a promessa de melhor atendimento à parturiente e ao recém-nascido, numa possível melhora da 'fisiologia falha' do corpo feminino, trouxeram consigo a crescente hospitalização, o aumento de intervenções, a institucionalização do chamado 'parto normal', na realidade um "circo de horrores" (Lanski apud Batalha, 2012, p. 9), no qual a mulher é submetida a uma série de intervenções desnecessárias e, em sua maioria, dolorosas. Pérez \& Gérvas (1999) denominaram “crueldade terapêutica" esse uso desnecessário de procedimentos médicos e cirúrgicos que se realizam simplesmente porque se tem poder para fazê-lo. Diniz \& Chacham (2006, p. 83) falam de uma “obstetrícia de linha de montagem”, na qual o uso de ocitocina sintética para acelerar o parto, o corte na vagina (episiotomia), o uso do fórceps e a manobra de Kristeller são transformados em procedimentos de rotina - ainda que essas práticas não se fundamentem em uma medicina baseada em evidências. Segundo Sonia Lansky (apud Batalha, 2012, p. 9), esse cenário faz com que o parto prevaleça no imaginário da mulher como uma tortura da qual seria preciso fugir, e no imaginário do médico predomina a crença de que, com a cirurgia cesariana, que não implicaria em danos, ele pudesse controlar a natureza e organizar melhor o ritmo de trabalho. Muito possivelmente também daí resulte nossa posição de um dos campeões do mundo em número de cesáreas. Como assevera Diniz (2009, p. 315), as cesáreas bem indicadas são essenciais em um sistema de cuidado obstétrico, entretanto ela também aponta o "paradoxo da cesárea", o fato de a cesárea poder ser mais danosa que providencial, quando sua taxa de ocorrência está aquém ou além de determinados parâmetros:

Uma porcentagem entre $5 \%$ e $15 \%$ do total de partos parece conseguir os melhores resultados para a saúde de mulheres e de bebês, visto que uma taxa menor que $1 \%$ ou mais alta que $15 \%$ parece fazer provocar mais dano do que benefício, o chamado paradoxo da cesárea. (Diniz, 2009, p. 315)

Gonçalves (2014, p. 58) lembra ainda que no "contexto [de medicalização/hospitalização do parto] surgiu um antagonismo entre o conhecimento técnico-científico, exercido principalmente por homens, e o conhecimento popular, transmitido de forma oral e praticado por mulheres", com consequente repressão ao trabalho das parteiras tradicionais, consideradas incompetentes e atrasadas, por se valerem muitas vezes também de rezas e "bruxarias." A antropóloga Tornquist ressalta que 
[...] toda sorte de especialistas de cura, populares e/ou familiares, como benzedeiras, curandeiras e parteiras, foram perseguidas, desqualificadas e banidas desta arte, e, com elas, um conjunto significativo de conhecimentos das próprias mulheres sobre seus próprios corpos, suas dinâmicas, seus produtos (Tornquist, 2004, p. 73-4).

[...]

A metáfora da mudança de endereço da casa para o hospital, [...], usada para sinalizar a alteração na forma de parir e de assistir o parto é, de fato, muito apropriada e carregou consigo uma sucessão de mudanças: passou de ofício a profissão, de affaire de femmes para assunto de homens, de pobres para elites escolarizadas, das mãos negras para luvas brancas, do rural para o urbano, de saberes populares para saberes científicos, de corpos pulsantes para corpos patológicos, de técnicas mecânicas e ritos espirituais para técnicas químicas, de uma percepção abrangente para um olhar esquadrinhador e meticuloso (Tornquist, 2004, p. 98)

Como salienta Mott (2002), embora a capacidade de dar à luz faça parte da fisiologia da mulher e da reprodução da espécie "desde o início dos tempos", o parto em si envolve práticas e costumes que ultrapassam em grande escala o meramente fisiológico, refletindo muitos dos aspectos culturais de uma determinada sociedade em um determinado tempo.

No Brasil, é crescente a visibilidade dos problemas que atingem mulheres e crianças no momento do parir e do nascer. Os números de partos cirúrgicos no Brasil fazem parte dos mais elevados mundialmente. Os dados do Departamento de Informática do Sistema Único de Saúde (DATA- SUS) do Ministério da Saúde (MS) apontaram taxa de 39,7\% em 1997, sendo que esse número excluía hospitais privados, que tradicionalmente apresentam taxas mais altas de cesarianas (cf. Hotimsky, et al. 2002, p. 1304). ${ }^{3}$ Segundo dados da Unicef (2013), o Brasil "apresenta provavelmente as mais altas taxas de cesarianas no mundo. Sua frequência aumentou de 38\% de todos os partos em 2000 para 54\% em 2011" Citando dados do Conselho Federal de Medicina, Hotimsky et al. salientam que as repercussões disso são, entre outras consequências negativas, elevados riscos de infecção puerperal, de mortalidade e morbidade materna, de prematuridade e mortalidade neo-natal, além de uma recuperação mais difícil para a mãe, com separação entre mãe e bebê e consequente retardo do início da amamentação (CFM, 1997, apud Hotimsky, et al. 2002, p. 1304). É, contudo, importante ressaltar que o aspecto do elevado índice de cesarianas é apenas a ponta de um iceberg, da violência obstétrica institucional que atinge mulheres brasileiras. Conforme Simone Diniz (2009, p. 321), esse índice de cesariana seria não

3Cabe ressaltar que a Organização Mundial da Saúde (OMS) considera adequada a taxa de 15\% de partos cirúrgicos. 
somente um aspecto, mas antes uma consequência da violência sofrida por mulheres durante a "assistência" ao parto vaginal, seria resultado de uma busca por dignidade. Em suas palavras:

A demanda pela cesárea, no Brasil, seria sobretudo uma demanda por dignidade, já que o modelo de parto "normal" típico é intervencionista e traumático. Trata-se de "uma escolha entre o ruim e o pior", entre duas formas de vitimização. Nas palavras de uma usuária, "se tiver que cortar é melhor cortar por cima, porque em baixo é uma área mais nobre".

Considerando-se que a OMS, há quase trinta anos, reitera não haver justificativa para que em região alguma do mundo a taxa de partos cirúrgicos seja superior a 10 ou 15\% (cf. Lauer et al. 2010, p. 5), entendemos serem as taxas referentes à realidade brasileira indicadores da constante conversão do evento fisiológico que é o parto em um processo patológico, e também do uso abusivo de medicação, ou seja, da violência obstétrica institucional vigente no Brasil.

Dito isso, finalizo esta seção deixando, por ora, a violência de lado e, na seção que se segue, passo a falar da resistência, na qual também se insere esse esforço de pesquisa discursiva crítica.

1.2. "Eu tenho me realizado usando minha própria experiência para alertar outras mulheres": a resistência.

Onde há violência há também resistência. E uma reação insurgente diante desse quadro de violência são as associações de mulheres organizadas em redes horizontais de solidariedade, que promovem a emancipação e o protagonismo feminino na hora da chegada de sua prole a este mundo. Tanto grupos mais institucionalizados - como o Grupo de Apoio à Maternidade Ativa, Amigas do Parto, Doulas do Brasil, Rede pela Humanização do Parto e Nascimento e Parto do Princípio - quanto a ação de mulheres engajadas, de maneira mais fluida, menos institucionalizada, pela humanização do nascimento e do parto têm se destacado nesse contexto. No último caso, encontramos, por exemplo, a utilização da Internet, com a publicação e a manutenção de blogs ou outras ferramentas digitais por meio das quais mulheres compartilham suas experiências com outras mulheres, exercendo assim importante agência nessa campanha de várias frentes por uma assistência obstétrica digna, respeitosa e não-intervencionista - o blog “Cientista que virou mãe” ilustra exemplarmente esse movimento ${ }^{4}$. Grupos de livre associação

4 http://www.cientistaqueviroumae.com.br/. 
em redes sociais virtuais, como os grupos “Cesárea não, obrigada!” ou "Parto Ativo Brasil" 5“, entre muitos outros, são exemplos do êxito dessa modalidade de ação, resistência coletiva, horizontal e solidária entre mulheres e pelas mulheres.

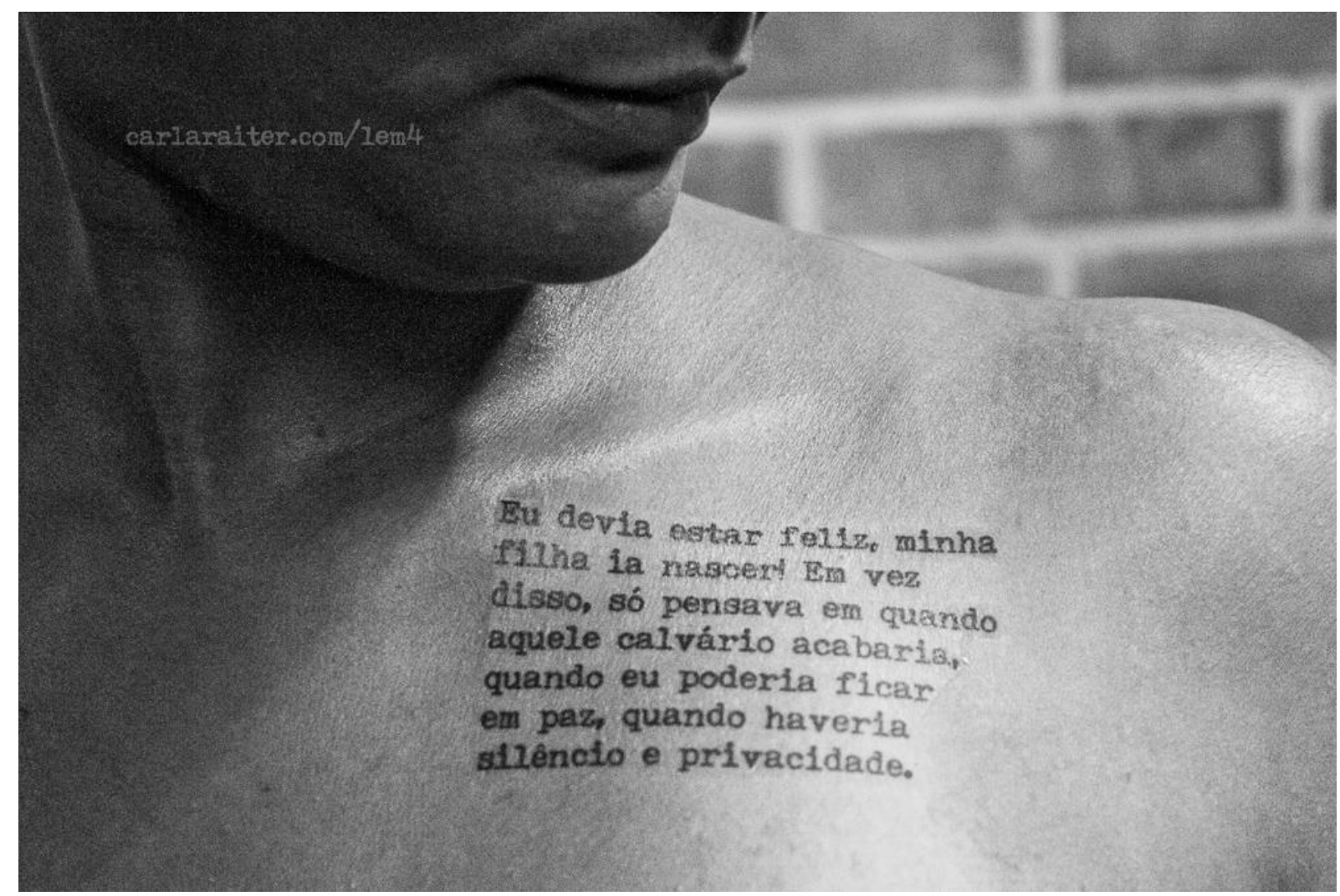

Figura 2 - Foto da campanha fotográfica realizada por Carla Raiter, entitulada Violência Obstétrica na Pele, amplamente divulgada nas redes sociais.

Como observa Tornquist (2002, p. 483-4), pode-se falar de um movimento pela humanização do parto e do nascimento no Brasil desde o final dos anos 1980. Isso significa que um

conjunto de medidas tidas, então, como humanizadoras busca desestimular o parto medicalizado, visto como tecnologizado, artificial e violento, e incentivar as práticas e intervenções biomecânicas no trabalho de parto, consideradas como mais adequadas à fisiologia do parto, e, portanto, menos agressivas e mais naturais.

No Hospital Universitário de Brasília (HUB), para nomear uma iniciativa essencial, central para a concepção do projeto para esta pesquisa, vem sendo desenvolvido, desde 1998, um trabalho de extensão universitária voltado para a promoção da saúde sexual e reprodutiva, coordenado pela professora doutora, enfermeira obstetra e parteira Silvéria Maria dos Santos. O objetivo do

55 http://partoativobrasil.com.br/. 
chamado Grupo de Gestantes do HUB é contribuir para o resgate da autonomia da mulher, por meio de atividades de sensibilização e orientação educativa, promovendo a emancipação feminina, para que as mulheres possam se ver e ser vistas e aceitas em toda sua complexidade e plenitude pela equipe de assistência ao parto (Oliveira, 2002). Para tanto, são organizados encontros semanais, abertos à comunidade, especialmente a gestantes, nos quais a reflexão e a orientação se desenvolvem, motivadas pelos temas trazidos pelo público presente na roda de discussão, em uma interação que possibilita a troca horizontal de experiências entre todas/os as/os presentes: gestantes, acompanhantes, professoras/es e alunas/os da área de saúde lato sensu.

Essa rede de resistência pode ser entendida como um projeto identitário coletivo, por meio do qual se busca - e se alcança - uma mudança do discurso vigente, um deslocamento hegemônico, nos termos de Gramsci, e a constituição de outro lugar subjetivo para a mulher na vivência de sua vida reprodutiva. Segundo Castells (1999, p. 22), identidade é “o processo de construção de significado com base em um atributo cultural, ou ainda um conjunto de atributos culturais inter-relacionados, o(s) qual(ais) prevalece(m) sobre outras fontes de significado". Reconhecendo que a construção da identidade sempre se dá em contextos de poder, Castells (1999, p. 24) propõe três formas de construção da identidade:

Identidade legitimadora: introduzida pelas instituições dominantes da sociedade no intuito de expandir e racionalizar sua dominação em relação aos atores sociais (...); Identidade de resistência: criada por atores que se encontram em posições/condições desvalorizadas e/ou estigmatizadas pela lógica da dominação, construindo, assim, trincheiras de resistência (...); Identidade de projeto: quando os atores sociais, utilizando-se de qualquer tipo de material cultural a seu alcance, constroem uma nova identidade capaz de redefinir sua posição na sociedade e, ao fazê-lo, de buscar a transformação da estrutura social.

Conforme esse autor, identidades de resistência levariam à formação de comunidades ligadas à resistência coletiva a modos específicos de opressão, experimentados pelos membros da comunidade, mas seriam as identidades de projeto que se associariam à formação do ator social coletivo, tornando-se recurso para projetos de mudança social. Aplicando essas categorias ao movimento de resistência das mulheres no Brasil, creio não ser bem possível traçar limites tão claros entre as distintas atuações de tantas mulheres, a maioria delas exercendo a maternidade paralelamente a tantos outros papéis sociais. O que percebo é que existe a resistência constante, mais ou menos silenciosa, mais ou menos explícita, com momentos pontuais, ou nem tanto, em que essa resistência se concretiza em projetos, maiores ou menores, mais ou menos possíveis, 
diante das limitações de uma 'guerra de trincheiras'. E esses pequenos ou grandes projetos vão mudando o fluxo do 'rio de conhecimento' que é o discurso sobre o parir e o nascer, enfim, sobre o ser mulher e mãe no Brasil.

O projeto que funda o trabalho investigativo, analítico e reflexivo aqui apresentado reside também não somente na busca individual pelo desenvolvimento acadêmico-científico e pela emancipação feminina, mas sobretudo na solidariedade inscrita neste empenho, que faz eco e amplifica a voz de outras tantas protagonistas de sua própria emancipação e da libertação da posição subjetiva alvo da violência de gênero de toda sorte, inclusive de uma violência obstétrica institucionalizada e normalizada. Em minha pesquisa, enfoco especificamente a representação discursiva da gestação e do parto no Brasil, onde a questão da violência obstétrica é uma preocupação transdisciplinar que tem motivado pesquisadoras/es em diversas áreas do conhecimento - saúde, história, antropologia, enfermagem, medicina, assistência social, psicologia, sociologia, linguagem, comunicação (ver, entre outros, Mott, 2002; Tornquist, 2004; Diniz \& Chacham, 2006; Morais, 2010; Dias, 2007 e 2015; Gonçalves, 2014) - a realizar investigações sobre essa questão, desde uma perspectiva crítica. O quadro de medicalização desnecessária do parto, no qual intervenções cirúrgicas se converteram em procedimentos de rotina, motivados não pela necessidade de sanar patologias, mas sim por uma imaginada possibilidade de aperfeiçoamento da fisiologia, é uma das preocupações que motiva esses trabalhos.

A abordagem crítica pressupõe uma postura científica comprometida com a mudança social. Além de engajada, a pesquisa crítica é também realizada por um/a pesquisador/a reflexiva/o, que não parte de pressupostos de neutralidade científica, mas sim da inevitável subjetividade a influenciar todos os seus passos, buscando dar transparência a sua prática de pesquisa também no que diz respeito a essa subjetividade. Ainda sobre a assunção da subjetividade e de seu incontornável papel na pesquisa, devo dizer que, nesta pesquisa, considero valer para o estudo das questões sociais o mesmo que Heisenberg \& Bohr (apud Santos, 2006, p. 43) defendem valer para a física quântica, a saber: não se pode medir, avaliar, um objeto sem interferir nele, a ponto de se poder afirmar que o objeto que sai de um processo de medição não é o mesmo que entrou lá, pois a ação da/o pesquisador/a sobre ele o transforma inevitavelmente. Neste ponto, gostaria mesmo de ir além e seguir as pistas deixadas por pensadores, como Paul Feyerabend, que lançam dúvidas acirradas sobre a pertinência da dicotomia sujeito-objeto de pesquisa. Feyerabend (2007, p. 33) propõe que "a ciência não conhece, de modo algum, 'fatos 
nus', mas que todos os 'fatos' de que tomamos conhecimento já são vistos de certo modo e são, portanto, essencialmente ideacionais".

Nessa perspectiva crítica da prática de pesquisa é que tenho investigado a ação, a representação e a identificação de mulheres interligadas em redes sociais relacionadas ao gestar, ao parir e ao nascer. A investigação empírica foi realizada por meio de pesquisa de cunho etnográfico, presencial e virtualmente, e da Análise de Discurso Crítica (ADC) (M. Jäger, 1996; Chouliaraki \& Fairclough, 1999; Fairclough, 2003; S. Jäger, 2012), cujas ferramentas permitem investigar, no âmbito da Linguística, questões relacionadas à forma como os atores sociais constroem e representam sua agência na sociedade.

Motivação para o projeto foi também a iminente mudança histórica, na qual diferentes facetas discursivas - desde a possibilidade de parto orgásmico até as vantagens de uma cesárea eletiva - se combinam em vias de produzir novos e complexos discursos, que não necessariamente serão sínteses dos discursos anteriores. A concepção de discurso adotada na tese é uma concepção dialética, que, de acordo com Magalhães \& Leal (2003, p. 13), se adéqua a analisar a linguagem como momento da prática social. Apesar de dialética, a concepção adotada não se resolve necessariamente pela síntese, e pode ser caracterizada também como transformacional, pois envolve tanto a reprodução quanto a transformação das práticas sociais dentro do quadro de relações de forças dadas que, em uma conjuntura de mudança histórica, travam as batalhas pela hegemonia, nos termos de Antonio Gramsci (apud Hall, ${ }^{6}$ 2000). Sobre esse aspecto transformacional, Resende ressalta, baseada em Archer (2000 apud Resende, 2013, p. 345) que "toda atividade social pressupõe condições estruturais sincrônicas e possui um potencial para transformar diacronicamente essas mesmas condições".

Com meu projeto inicial buscava, desde o início, para além da discussão meramente teórica ou linguística, contribuir para uma produção de conhecimentos que pudessem colaborar com atores sociais empenhados nessa busca por uma "nova" maneira de parir e de nascer. Entretanto, agora não afirmo mais estar buscando o empoderamento das mulheres, como afirmei

\footnotetext{
6 Gostaria de registrar que, embora saiba da orientação sobre a necessidade de consulta às obras originais quando repetir em meu próprio texto uma citação encontrada em literatura secundária, e assim tenha procedido, sempre que as condições externas me tenham permitido, faço questão de manter em toda minha tese os apud necessários como forma de reverência e reconhecimento do valor de textos, seja mais introdutórios, seja mais didáticos ou envolventes, que me influenciaram e motivaram o aprofundamento ou o direcionamento de minhas leituras em uma determinada direção. Ainda que tenha consultado os originais, mantive o apud sempre que a ideia inicial de citar uma passagem específica não tenha sido minha. Aproveito para afirmar que, em caso de citações sem apud, a ideia e a seleção da citação resultou diretamente de minhas leituras do texto original.
} 
inicialmente. No decorrer do percurso e com o amadurecimento de minhas reflexões, sobremaneira devido a leituras e discussões com colegas e orientadoras, optei por não trabalhar mais com esse conceito de empoderamento, mas sim com a ideia de emancipação, pois concordo com Resende (2008, p. 103-4), quando pondera que

[p]esquisas socialmente engajadas têm sido referidas como pesquisas comprometidas com o empoderamento (Cameron et al., 1992). O termo 'empoderamento', entretanto, guarda uma contradição, pois sugere uma perspectiva segundo a qual pesquisadores/as seriam detentores de 'poder' a ser redistribuído entre sujeitos 'desempoderados'. Sabemos, contudo, que há diferentes tipos de conhecimento e diferentes tipos de poder distribuídos na sociedade. Nesse sentido, todo sujeito excluído de uma prática estará incluído em outras, o que implica que o próprio conceito de exclusão é sempre relativo a algo específico. Assim, o que uma pesquisa como a que conduzi pode ambicionar em termos de resultados práticos está mais ligado à reflexão que pode desencadear no contexto pesquisado, à desnaturalização de representações tomadas como tácitas, ao desvelamento de mecanismos causadores de questões problemáticas ou bloqueadores de soluções (Outhwaite, 1998).

No sentido de desnaturalizar representações tomadas como tácitas, diante da formação especializada de obstetras em nossa sociedade, que tantas vezes menosprezam os processos fisiológicos próprios da natureza da mulher, ignorando suas capacidades inatas e sua complexidade como ser humano, e diante da falta de reconhecimento do valor do ofício da parteira (tradicional), justifica-se, juntamente com Boaventura de Sousa Santos (2006, p. 18), perguntar "pelo papel de todo conhecimento científico acumulado no enriquecimento ou no empobrecimento prático de nossas vidas, ou seja, pelo contributo positivo ou negativo da ciência para nossa felicidade." Portanto, não se trata de negar a contribuição dos avanços medicinais e tecnológicos, mas de estar atentas/os para não perder o foco no ser humano ou em sua plenitude.

1.3. Acontecimentos discursivos. Do parto domiciliar de Sabrina ao parto roubado de Adelir.

Ainda no intuito de seguir contextualizando a questão nesta época estudada, gostaria de

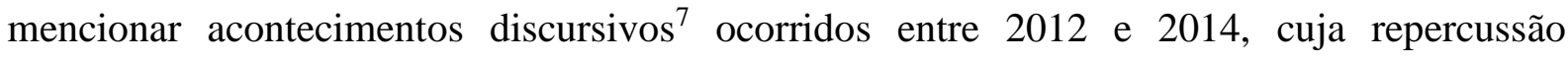
reflete/influencia o curso do movimento por uma assistência obstétrica adequada. Escolhi começar pela publicação, em 2012, do vídeo do parto domiciliar de Sabrina Ferigato, publicado

7 Eventos que têm uma grande repercussão midiática e que, por isso mesmo, podem influenciar a direção e a qualidade do feixe discursivo a que se referem (S. Jäger, 2012, p. 82). 
no site de compartilhamento de vídeos em formato digital Youtube, retratando o nascimento do seu primeiro filho, Lucas. A publicação obteve, em menos de uma semana, mais de 145.000 acessos, e uma das consequências dessa repercussão foi uma reportagem realizada pelo programa televisivo Fantástico, uma revista eletrônica transmitida semanalmente há 40 anos e que alcança grande parte da população brasileira nas noites de domingo. Na reportagem, participaram tanto a família de Lucas quanto profissionais da área da atenção ao parto, como o médico Jorge Kuhn, que, na ocasião, se pronunciou positivamente sobre a segurança do parto domiciliar.

No dia seguinte à exibição da reportagem, o Conselho Regional de Medicina do Rio de Janeiro (CREMERJ) encaminhou denúncia contra o médico ao Conselho Regional do Estado de São Paulo (CREMESP) devido ao posicionamento, pois, conforme a presidenta do Conselho, Márcia Rosa de Araujo (CREMERJ, 2012a), seriam "muitas as complicações possíveis durante um trabalho de parto, que demanda[ria]m atendimento médico imediato, em local equipado e com uma equipe preparada para enfrentá-las. Por isso, o CREMERJ é contra a realização de partos domiciliares". A notícia "CREMERJ denuncia médico que defendeu parto domiciliar", publicada em 19 de junho de 2012, ainda podia ser acessada entre os informes da página oficial do CREMERJ (2012) em meados de 2016 e versava o seguinte:

O Conselho Regional de Medicina do Estado do Rio de Janeiro (CREMERJ) encaminhou denúncia ao Conselho Regional de Medicina do Estado de São Paulo (Cremesp) contra o médico Jorge Francisco Kuhn, que participou de reportagem do Fantástico defendendo o parto domiciliar. A denúncia foi encaminhada ao Cremesp no dia 11 de junho. "São muitas as complicações possíveis durante um trabalho de parto, que demandam atendimento médico imediato, em local equipado e com uma equipe preparada para enfrentá-las. Por isso, o CREMERJ é contra a realização de partos domiciliares", explica a presidente do Conselho, Márcia Rosa de Araujo.

O parto é um processo dinâmico, em que não se pode estabelecer o risco mesmo em mulheres sadias e com pré-natal sem anormalidades. Já em junho de 2007, o Conselho emitiu o parecer 185/2007 desaprovando a prática. "É importante ressaltar que a legislação médica vigente não contempla partos não-hospitalares. Assim, o médico não fica respaldado em eventuais complicações, salvo nos casos de iminente risco de vida", explica a primeira vice-presidente do CREMERJ, a obstetra Vera Fonseca.

Em entrevista para o Fantástico, neste domingo, 17, uma semana após a colocação do médico Jorge Francisco Kuhn, o conselheiro Luís Fernando Moraes expõe o posicionamento do CREMERJ: "Nós entendemos que as afirmações não são éticas. Em um parto, não se pode correr risco nenhum". O posicionamento do CREMERJ é acompanhado pelo Conselho Federal de Medicina (CFM), por todos dos Conselhos Regionais de Medicina do país e por entidades como a Federação Brasileira de Ginecologia e Obstetrícia (Febrasgo) e pela Sociedade de Ginecologia e Obstetrícia do Estado do Rio de Janeiro (Sgorj), entre outras. 
Em resumo, a nota do CREMERJ, além de ressaltar suposto risco inerente ao parto, afirma já se opor à prática do parto domiciliar desde 2007, menciona a legislação médica vigente, que não contemplaria partos domiciliares, acusa o posicionamento de Jorge Kuhn como antiético e cita outras agremiações profissionais médicas como pares nesse julgamento. E, de fato, em agosto do mesmo ano, o Conselho Federal de Medicina (CFM, 2012) publicou uma nota defendendo a primazia do ambiente hospitalar para a o evento do parto, devido aos "riscos de mortalidade e de morbidade envolvendo partos realizados fora do ambiente hospitalar”. Esse foco no risco é recorrente nos posicionamentos das associações médicas e confirma a assertiva da pesquisadora australiana Alphia Possamai-Inesedy (2008), segundo a qual, devido ao status especial e protegido do evento do parto, construído social e culturalmente, tanto a mãe quanto a criança se colocam no foco do risco e da ansiedade. E esse fato pode ser apropriado em favor de interesses diversos, eu diria. Possamai-Inesedy (2008), levando em consideração a teoria de Ulrich Beck (1986) sobre a sociedade do risco, defende ainda que, em termos de saúde, especialmente no que diz respeito à gestação e ao nascimento, o risco não é encarado em termos positivos. Segundo ela, o corpo gestante é concebido como duplamente em risco e duplamente responsável, sendo que a culpa pelo risco que possa eventualmente acometer a gestante ou ao feto é projetada predominantemente sobre a mulher.

Conforme relembra Aline Goncalves, em sua dissertação de mestrado, Da Internet às ruas: $a$ Marcha do Parto em Casa (2014), "a primeira vez que o parto domiciliar ganhou destaque na mídia brasileira, em 2012, foi em $1^{\circ}$ de fevereiro quando a australiana Caroline Lovell, reconhecida como defensora do parto em casa, morreu após ter tido seu segundo filho em casa". Logo após a divulgação do ocorrido, no dia 2 de fevereiro de 2012, o CREMERJ divulgou uma nota em seu site - "Nota oficial do CREMERJ sobre parto domiciliar" -, lamentando o falecimento de Caroline e aproveitando o ensejo para condenar a opção pelo parto domiciliar:

Há anos o CREMERJ vem alertando sobres os riscos desse tipo de parto, afirmando que não se trata de uma questão corporativa, mas sim de consciência, de garantir a saúde e a vida dos pacientes. "Nossa afirmações têm bases científicas", destacou a presidente do Conselho, Márcia Rosa de Araujo. Para o CREMERJ, atualmente não existe sentido em se realizar um parto em casa, já que a paciente estará sujeita a consequências potencialmente perigosas. "Infelizmente, mesmo com condições de ter seus filhos em hospitais, amparadas por médicos e com todo o respaldo tecnológico, algumas mulheres ignoram a existência de adversidades e preferem se arriscar", comentou o Conselheiro Luís Fernando Moraes, que é ginecologista e obstetra.

O Conselho continuará repudiando os partos domiciliares e não se furtará de ser exercer o seu papel fiscalizador, coibindo a prática. "Em nosso juramento 
afirmamos que faremos tudo o que estiver ao nosso alcance para salvar vidas, mas sabemos que existem médicos que participam desses partos domiciliares, mesmo isso sendo proibido pelo nosso Código de Ética", salientou Luís Fernando.

O CREMERJ espera que as mulheres se conscientizem sobre o assunto, garantindo que outras vidas sejam poupadas.

Nessa nota, O CREMERJ apela à consciência, afirma não fazer sentido o parto domiciliar, atribui ignorância às mulheres que optam por parir em casa, se "arriscando", acusa, indiretamente, os médicos que atendem a parto domiciliares como antiéticos e como profissionais que, contra o juramento médico, não estariam fazendo de tudo para salvar vidas, e, por fim, confirmando a proposição de Possamai-Inesedy, mencionada anteriormente, apela somente (!) às mulheres, mas não a colegas de profissão, para que garantam que "outras vidas sejam poupadas". Mas se com isso lhes atribui a culpa ou a responsabilidade por possíveis riscos durante o parto, ainda assim deixam evidente a percepção sobre quem, ao fim e ao cabo, tem de fato o poder para definir os rumos sobre o lugar a ser reconhecido como legítimo para o parto: nós mulheres.

Além dessas notas, ainda por ocasião da declaração de Jorge Kuhn no programa televisivo, o CREMERJ (2012b; 2012c) publicou as resoluções 265 e 266, declarando vetadas tanto "a participação do médico nas chamadas ações domiciliares relacionadas ao parto" quanto "a participação de pessoas não habilitadas e/ou de profissões não reconhecidas na área da saúde durante e após a realização do parto, em ambiente hospitalar", e incluindo expressamente nessa proibição “as chamadas 'doulas', 'obstetrizes', 'parteiras' etc.”.

Diante de tal arbitrariedade, no domingo seguinte, aconteceu, fruto de uma articulação coletiva e decentralizada, organizada horizontalmente, sobretudo pelas redes sociais virtuais, uma marcha em defesa do direito de escolha, a chamada Marcha do Parto em Casa, quando centenas de pessoas, em mais de 30 cidades brasileiras foram às ruas pelo direito de parir onde, como e na companhia de quem quiserem. A Marcha, além de um evento pontual bastante bemsucedido, representa mais um momento de reforço dos laços de solidariedade entre mulheres unidas em nosso projeto emancipatório coletivo. 


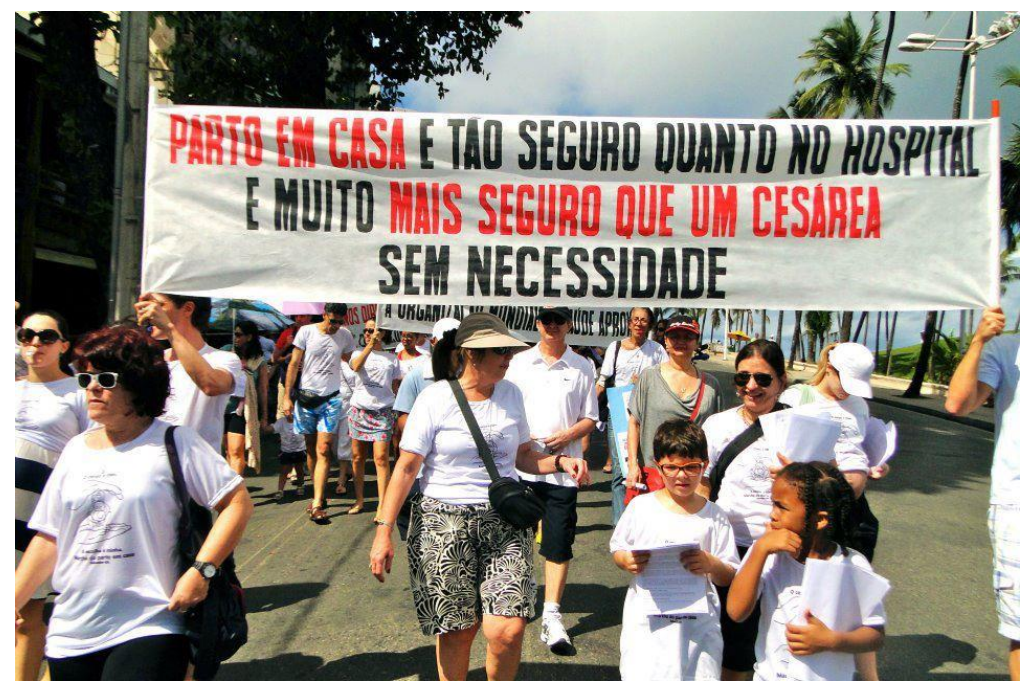

Figura 3 - Marcha do Parto em Casa, Salvador (BA), 2012. Fonte: Marcha do Parto em Casa (Facebook)

Na análise que fez da Marcha do Parto em Casa, Gonçalves (2014, p. 14) escreve que tais ações têm o potencial de fortalecer a identidade das mulheres que se reconhecem como grupo. Em suas palavras,

mulheres brasileiras fortalecem a sua identidade a partir de ações de comunicação que levam ao reconhecimento de problemas comuns enfrentados no período da gestação, parto e pós-parto. Ao se reconhecerem como grupo, elas desencadeiam outras ações de comunicação e mobilização visando sensibilizar a sociedade, exigir mudanças nos procedimentos médicos, nas políticas públicas e, possivelmente, transformar a cultura vigente.

A autora caracteriza esse evento como uma ação coletiva, que como tal apresentaria "desafios teóricos e metodológicos que vão além daqueles debatidos em torno da participação política e das formas já conhecidas de organizações da sociedade civil, como os partidos ou os movimentos sociais" (Gonçalves, 2014). Graças aos recursos tecnológicos acessíveis a muitas pessoas desde o início deste século, nomeadamente a rede mundial de computadores e os dispositivos móveis de comunicação, a ação social assume uma característica mais fluida, distinguindo-se de formas de atuação tradicionais, embora isso não impeça que o movimento pela humanização do parto e do nascimento possa ter características elitistas, por partir de um modelo de mulher padrão correspondente à mulher branca, escolarizada e de classe média. Segundo Shirky (2010, p. 23 apud Gonçalves, 2014, p. 33), "estamos vivendo em meio a um extraordinário aumento de nossa capacidade de compartilhar, de cooperar uns com os outros e de empreender ações coletivas, tudo isso fora da estrutura de instituições e organizações 
tradicionais". E se, após esse esforço, ao fim da Marcha que saiu da Internet e foi às ruas, voltamos para casa, essa volta para casa é, conforme Gonçalves (2014, p. 33), “acompanhada da continuidade das trocas e discussões em ambiente virtual que fomentaram outros 'acontecimentos': petições, denúncias às instâncias judiciais, proposições de políticas públicas, entre outros". Por isso mesmo, essa Marcha especificamente é aqui considerada um acontecimento discursivo digno de menção.

Outro acontecimento discursivo notável ocorreu no ano seguinte, em 2013. Após um período de cerca de dois anos de produção, graças a um recorde de arrecadação em financiamento coletivo, chegou às salas comerciais de cinema de 50 cidades do Brasil o documentário " $\mathrm{O}$ Renascimento do Parto", alcançando um público de mais de 30.000 pessoas. O filme apresenta uma visão da situação do parto no Brasil, por meio de depoimentos de famílias e profissionais da assistência, enfatizando os riscos e negatividades de uma cesárea e promovendo as vantagens de um parto domiciliar atendido por equipe multidisciplinar. Mais uma vez a questão do risco é ativada, não um risco referente ao evento do parto domiciliar, mas sim a uma cirurgia cesariana. O relevo desse risco na narrativa do documentário é marcante, e isso levou uma de minhas colaboradoras, Elena, a declarar, durante encontro para conversarmos sobre o filme também com uma parteira, que, felizmente, ela já havia vivido a experiência de um parto domiciliar respeitoso após a cesárea indesejada, pois não fosse isso, ela teria saído emocionalmente ainda mais abalada da sala do cinema. Perguntei então se ela escreveria um comentário sobre o filme para esta pesquisa e ela atendeu prontamente. No texto, que pode ser lido na íntegra no Anexo 1, ela afirma, por exemplo, que:

Eu gostei de assistir ao filme, sai do cinema me sentido bem. Mas acho que tive esse sentimento pelo fato de ter tido sucesso no meu parto domiciliar. Talvez, se eu não tivesse passado por essa experiência, não tivesse nem coragem de assistir. E certamente sairia arrasada do cinema se assistisse. $\mathrm{O}$ filme tem vários méritos, trata de assuntos e assume posicionamentos que não são muito difundidos para o público em geral. Porém, ao mesmo tempo é muito taxativo e talvez chegue a "discriminar" quem não compartilhe das mesmas opiniões ou quem não teve acesso às informações e opiniões divulgadas.

Sempre que aparecia uma cena de cesárea me sentia muito mal, via a minha filha na pele daqueles bebês que estavam sofrendo nascendo daquele jeito. Me sentia muito culpada, assim como sempre me sinto quando vejo uma cesárea. Mas a cesárea foi mostrada apenas como o "bicho papão", como uma conduta terrível, não foi falado nada sobre as cesáreas necessárias, salvadoras. Me pareceu que o filme passa a mensagem de que o parto natural, humanizado, perfeito etc está disponível para qualquer uma, basta querer e correr atrás. E na minha opinião não é bem assim. Sei porque sofri isso na pele, porque precisa de dinheiro, de contatos, às vezes de sorte, de estar em um lugar onde 
haja profissionais certos disponíveis e acessíveis e, às vezes, como no meu caso, de uma história de vida que leve a procurar por tudo isso.

Nesse mesmo ano de 2013, veio ao mundo, por meio de um parto natural "simplesmente perfeito", o filho de Kate Middleton, da família real inglesa, fato que repercutiu internacionalmente e motivou a publicação de inúmeros textos, entre eles um artigo intitulado “Cesariana é coisa de plebeu”. Entendo que acontecimentos discursivos como o documentário supracitado, que contou com a presença da família de um famoso ator de telenovela, e a associação do parto natural à imagem de uma "princesa", têm o potencial de (re)produzir a imagem de um parto natural "perfeito", como um sonho a ser atingido. A questão que se põe aqui, entretanto, é se a imagem do sonho idealizado seria um sonho de consumo restrito à "nobreza", ou um sonho como um direito universal pelo qual se deve lutar no âmbito da assistência pública e gratuita. Gonçalves, em seu estudo sobre a Marcha do Parto em Casa, ao citar blogs que criticam o uso do vocativo "mãezinha" por parte do pessoal da atenção obstétrica, faz uma observação que instiga essa crítica ao elitismo latente no movimento da humanização:

As mulheres mobilizadas criticam médicos que frequentemente usam a expressão "mãezinha" para tratá-las durante o pré-natal e a assistência ao parto. A expressão é considerada inadequada por elas porque infantilizaria a mulher e a colocaria em situação subalterna. Em relatos de partos, blogs e grupos em redes sociais, o uso do termo é bastante criticado pelas ativistas. Elas recomendam às leitoras (observa-se aqui que falam com aquelas que têm poder aquisitivo para poder escolher) a evitar hospitais e equipes de assistência que as tratam desta forma (Gonçalves, 2014, p. 50).

[...] o acesso constante à rede mundial de computadores, assim como ao uso de planos de saúde ou serviços de assistência à saúde privados relatado por muitas delas, as colocaria como pertencentes às classes sociais médias e altas, o que torna a iniciativa elitizada (Gonçalves, 2014, p. 55).

O poder de escolha, de opção por um hospital ou a contratação de uma "equipe humanizada" para o acompanhamento do parto domiciliar não está ao alcance de todas as mulheres. Mulheres cuja posição social, ou discursiva, pertencimento de classe, não correspondem àquela da mulher branca, escolarizada e de classe média, têm ainda menos espaço de manobra preventiva na tentativa de se esquivar a um atendimento desrespeitoso. Note-se que não consideramos esse possível elitismo como uma atitude consciente ou intencional, mas antes uma característica de um movimento impulsionado por mulheres que, desde sua própria experiência e posição 
discursiva $a^{8}$ interpretam o mundo. Esse seria um primeiro e necessário passo, que precede, mas de maneira alguma impossibilita um caminhar adiante rumo a um posicionamento que contemple interesses mais abrangentes, garantindo direitos, e não privilégios, a todas as mulheres. O conceito de posição discursiva nos ajuda a lidar com esse aspecto do movimento, dessas ações coletivas e, oxalá, a buscar alternativas rumo à mudança que almejamos para todas.

Ademais, é importante lembrar que cada um desses acontecimentos discursivos e suas repercussões estão constantemente (re)produzindo posições subjetivas para as mulheres, e há que se perguntar se em nosso movimento pela humanização não estamos reforçando imagens essencializadoras associadas à mulher, como a daquela cujo maior sonho é ser mãe, agora com a necessidade adicional de parir o "parto perfeito" para alcançar a realização pessoal. Ainda nos primeiros anos desse estudo, dei-me conta desse perigo e percebi a necessidade de, em meu trabalho, não ter como foco a defesa do parto natural, mas antes a defesa dos direitos das mulheres de serem livres para optar com liberdade por parir ou não, e serem respeitadas e tratadas com dignidade em qualquer caso. Mas, assim como o caminho se faz ao andar, a luta se constrói no lutar, e esse movimento pela humanização, ao qual me filio também com minha pesquisa, como qualquer outro movimento de luta por direitos, necessita constantemente de autorreflexão e ajuste de rota, baseada em argumentos sólidos, pautados na voz das mulheres. Digo isso sem, de maneira alguma, desconsiderar o fato de que essa luta, apesar de todas as necessidades de ajuste, já tenha resultado em contribuições evidentes e provocado reações por parte do status quo hegemônico, como vimos no caso da reação autoritária do CREMERJ.

Passando aos acontecimentos discursivos do ano de 2014, ressalto a primeira grande reação contra esse movimento de luta pela autonomia da mulher, e pelo direito ao protagonismo durante o próprio parto, com grande repercussão midiática e consequente visibilidade. No dia $1^{\circ}$ de abril de 2014, Adelir Carmem Lemos de Góes foi retirada de dentro de sua casa, no meio da noite, em pleno trabalho de parto, por nove policiais armados, para ser conduzida, contra sua vontade, a um hospital onde seria submetida, contra sua decisão, a uma cesariana. A médica

\footnotetext{
8 “ [...] lugar de onde se dá uma participação no discurso e sua avaliação para uma pessoa ou um grupo ou instituição. [...] O resultado do envolvimento em diversos discursos, aos quais o indivíduo foi exposto, e, durante sua vida, processou em um determinado posicionamento ideológico ou uma visão de mundo". (M. Jäger, 1996, p. 47)
} 
que a atendera, diante da recusa de Adelir de ser operada antes de tentar um parto normal, acionou a justiça, por entender que um parto normal poria em risco a vida do bebê, que se encontrava em posição pélvica. Embora não haja dispositivo legal algum que embase tal ação judicial, nem evidências científicas que respaldem a opinião da médica, ela conseguiu se impor como autoridade, ferindo o direito à autonomia de Adelir, garantido constitucionalmente.

Diante do ocorrido, uma ação coletiva culminou, 10 dias mais tarde, na realização do Ato Nacional "Meu corpo, minhas regras". No mesmo dia, houve uma manifestação do Governo Federal - presidido por Dilma Rousseff, a primeira mulher eleita presidenta da república no Brasil -, por meio de documento assinado pela Secretaria de Direitos Humanos da Presidência da República, pela Secretaria de Políticas paras as Mulheres e pelo Ministério da Saúde, advertindo a ilegalidade da submissão de Adelir à cirurgia e a violação dos direitos humanos configuradas nesse acontecimento:

As Secretarias de Direitos Humanos e de Políticas para as Mulheres da Presidência da República e o Ministério da Saúde vêm a público se solidarizar com Adelir Carmem Lemos de Goes, que foi submetida, contra sua vontade, a uma cesárea por decisão da Justiça no dia $1^{\circ}$ de abril na cidade de Torres (RS). Na oportunidade manifesta também apoio às medidas adotadas pelo governo do Rio Grande do Sul. A situação vivida por Adelir - parto cirúrgico sem consentimento - aponta para uma série de questões que envolvem os Direitos Humanos na Saúde e coloca as seguintes reflexões para nossa sociedade.

1. Os princípios de Direitos Humanos preconizam que todas gestantes têm direito a acesso a atendimento digno e de qualidade no decorrer da gestação, parto e puerpério, e que a assistência seja realizada de forma humanizada e segura. A mulher tem o direito de escolher como será o parto de seu filho, a posição do parto, e quem deve acompanhá-la nesse momento. Isso é Lei no Brasil. A não observância dessas questões - e outras - se configura em flagrante violação de direitos. A Resolução $n^{\circ} 50$, da Organização das Nações Unidas (ONU), reconhece que Direitos Humanos são parte dos princípios e valores inerentes à saúde (BRASIL, 2014).

Comentando tecnicamente o ocorrido, a enfermeira obstétrica, mestre em enfermagem, doutora em Ciências Médicas e parteira Maíra Libertad Soligo Takemoto (2014) publicou, no dia 4 de abril, uma nota na linha do tempo de seu perfil na rede social virtual Facebook, com a seguinte introdução:

A cesárea forçada da Adelir foi justificada pela equipe médica que a atendeu e pelos funcionários do judiciário que permitiram essa medida arbitrária com base em três condições clínicas diferentes:

a - 42 semanas completas de gestação, que em tese impediriam o parto normal e colocariam o bebê em risco 
b - Duas cesáreas prévias, que em tese impediriam o parto normal e colocariam o bebê em risco

c - Bebê sentado (bebê em pé no útero não existe), que em tese impediria o parto normal e colocaria o bebê em risco

As perguntas que não querem calar:

1 - Idade gestacional de 42 semanas é indicação de cesárea?

2 - Ter duas cesáreas prévias é indicação de cesárea?

3 - Ter um bebê sentado é indicação de cesárea?

E na sequência de seu texto, Takemoto responde a essas três perguntas, baseada em documentos como o Protocolo da OMS sobre Indução do Parto, o Protocolo do ACOG (Colégio Americano de Ginecologia e Obstetrícia) sobre Parto Normal Após Cesárea, e o Protocolo do ACOG sobre Parto Pélvico (com o bebê sentado), concluindo que, quando Adelir "chegou ao hospital em trabalho de parto avançado, o mais adequado considerando os protocolos e evidências científicas teria sido deixar o parto normal acontecer", ademais lhe deveria ter sido oferecida “a possibilidade de tentar um parto normal”, e que "não só o parto vaginal pélvico é possível, encontra respaldo em estudos científicos e protocolos, como não é possível afirmar com certeza que o risco de morte do bebê é maior no parto normal". Portanto, tecnicamente falando, nenhuma das características apresentadas por Adelir no hospital configuravam indicação absoluta para cesárea. Nem a idade gestacional de 42 semanas, nem o fato de ter duas cesáreas prévias, nem ter um bebê sentado na barriga. Continua, então, em aberto a razão que teria justificado a ação das autoridades no caso Adelir. Haveria alguma justificativa jurídica?

Considerando essa possibilidade, verificamos o posicionamento do juiz de direito José Henrique Torres, que, a convite da médica GO, feminista, professora, pesquisadora e ativista dos direitos sexuais e reprodutivos Melania Amorim, teve um guest post publicado em seu blog "Estuda, Melania, estuda". Torres ressalta não se ater especificamente ao caso ocorrido com Adelir, mas abordar a legislação de maneira mais geral, considerando o princípio constitucional da autonomia de pacientes, pois princípios não deveriam ser ignorados em nenhuma interpretação legal.

No que diz respeito a procedimentos médicos, Torres reforça o princípio da liberdade e da autonomia na aceitação ou não da oferta feita por médicas/os a pacientes, submetendo-se ou não a qualquer procedimento de acordo com sua própria vontade, de forma a ser reconhecida/o como sujeito de direito, e não como objeto de direito, cujas escolhas não poderiam ser impostas nem por médicas/os, nem pelo Estado, a sua revelia:

E, em consequência, quando se trata de qualquer procedimento médico, é 
preciso reconhecer que todas as pessoas têm a liberdade interna de querer e tomar a decisão de aceitá-los ou recusá-los, e, ainda, obviamente, a liberdade externa de agir conforme essa decisão, livremente, ou seja, a liberdade de submeter-se ou não a esse ou àquele procedimento médico.

$[\ldots]$

$\mathrm{O}$ inciso $\mathrm{X}$ do artigo $5^{\circ}$ da Constituição Federal Brasileira confere ao 'cidadão o direito de impedir que intrusos venham intrometer-se na sua esfera particular' [...] e "o direito à liberdade de que cada ser humano é titular para escolher o seu modo de vida' [...]. Essa garantia fundamental, como afirma o Ministro Luiz Fux, do STF, "traduz-se na previsão de que o indivíduo mereça do Estado e dos particulares o tratamento de sujeito e não de objeto de direito, respeitando-lhe a autonomia, pela sua simples condição de ser humano. Assim sendo, incumbe ao Estado garantir aos indivíduos a livre busca de suas realizações de vida pessoal".

$[\ldots]$

Como se vê, não cabe ao Estado, nem aos médicos, nem a ninguém, substituir o ser humano na definição de suas escolhas ou impedi-lo de agir de acordo com essas escolhas.

Enfim, nem técnica, nem juridicamente, encontramos uma justificativa para a atuação da médica e dos demais profissionais envolvidos na submissão de Adelir a uma cesárea forçada. Por isso recorremos à reflexão da jornalista Eliane Brum, publicada no jornal El País, no dia 14 de abril de 2016, em seu artigo intitulado "A potência de Adelir: Que dogmas tão profundos a gestante de Torres feriu para ter seu corpo violado pelo Estado na calada noite". No texto, a jornalista discute "aquela madrugada, [em que] Adelir descobriu que dois espaços que considerava privados, invioláveis, tinham sido invadidos no meio da noite: sua casa, seu corpo.” Brum ecoa nossas perguntas: “o que tornou Adelir tão perigosa, de repente? Que poder tão nevrálgico ela desafiou para mover tantas autoridades durante a noite? O que, de fato, ela estava ameaçando, para mobilizar uma demonstração de força dessa ordem?”. E a jornalista conclui que, ao dizer 'Não!', Adelir se tornou perigosa, pois dizer não seria uma ousadia diante de médicas/os que se consideram donas/os dos corpos das/os pacientes. Assim como donas/os das verdades sobre suas vidas, acrescento eu. Brum em seus termos:

Ao dizer "não", Adelir tornou-se perigosa. Como uma mulher, usuária do SUS, moradora da zona rural, recusa-se a cumprir a ordem de uma doutora? Como ela ousa escolher o que considera melhor para ela e para seu bebê? Não como uma inconsequente, mas como alguém que se preparou para o parto, informou-se, contratou uma doula para ajudá-la? Nem mesmo quando botam um termo de responsabilidade diante dela, sempre assustador para todos e mais ainda para os pobres, Adelir recua. Ela assina. E vai para casa continuar a se preparar para dar à luz sua filha.

Lendo Brum, poderíamos dizer que a razão que levou à submissão forçada de Adelir foi o significado simbólico de seu ato, inscrito em um movimento maior, na grande ação coletiva 
pela humanização do parto, inscrita num contexto histórico ${ }^{9}$ em que as pautas de interesses das chamadas minorias vinham sendo, ainda que timidamente, contempladas por meio de medidas de inclusão baseadas em critérios de gênero, classe e raça.

O impacto do caso Adelir culminou na proposição de um projeto de lei, que poderíamos chamar Lei Adelir. Em cooperação com ativistas, o deputado federal Jean Wyllys (2014), cuja atuação tem se destacado pelo empenho na concretização e proteção dos direitos humanos no Brasil, apresentou o Projeto de Lei 7633/2014, de 29 de maio de 2014, sobre a humanização da assistência à mulher e ao neonato durante o ciclo gravídico-puerperal.

Com essa discussão de alguns acontecimentos discursivos considerados centrais, espero ter provido uma contextualização não só do problema em questão, a violência de gênero que atinge atualmente 25\% das mulheres no Brasil (Fundação Perseu Abramo, 2010), mas também da mobilização, do movimento emancipatório pela recuperação do "parto roubado" e pelo respeito à dignidade e à autonomia da mulher.

Passo, agora, a discutir a abordagem adotada nesta pesquisa, os caminhos percorridos para chegar também a este capítulo. Esses caminhos não deixam de ser marcados pela resistência cotidiana imposta pela tradição disciplinar que, muitas vezes, quase sem querer, corre o risco de colocar o problema social a serviço de uma disciplina qualquer, quando deveria sim proporcionar a liberdade de interdisciplinaridade demandada pelo problema em questão.

\footnotetext{
${ }^{9}$ Nomeadamente durante os governos de Luiz Inácio Lula da Silva e Dilma Rousseff, de 2003 a 2016.
} 


\section{CAPÍTULO 2 Trilhas teórico-metodológicas. Tentando escrever certo apesar das linhas} tortas.

Reflexões metodológicas são, por assim dizer, um andaime, que serve de passagem de um trabalho que eu acabo de concluir para um próximo. Isso não é um método geral, que seria definitivo para outrem ou para mim. O que eu escrevi não são receitas, nem para mim nem para ninguém. São na melhor das hipóteses ferramentas - e sonhos.

(Michel Foucault)

Neste capítulo, exponho as decisões metodológicas tomadas pelos caminhos que me trouxeram, ou que eu trouxe, até aqui e nos encontros teóricos realizados nesse percurso. Para isso, achei conveniente contar um pouco da minha biografia, como parte das estruturas que foram tanto condição quanto resultado das minhas ações, ao longo dos últimos dez anos, aproximadamente. $\mathrm{O}$ faço por entender que minha pesquisa também é um componente de ação social, e concordo com Resende (2009) quando defende, inspirada em Margaret Archer, que "toda atividade social pressupõe condições estruturais sincrônicas e possui um potencial para transformar diacronicamente essas mesmas condições".

2.1. De Jena para Brasília. O Discurso na bagagem e a maternidade no meio do caminho.

Em 2007, como trabalho de conclusão no Magister Studium que cursei na Alemanha (Regis, 2007), realizei uma pesquisa sobre a integração de mulheres imigrantes brasileiras na Alemanha. Mais especificamente, busquei conhecer suas percepções sobre a oferta/exigência feita pelas autoridades daquele país para que frequentassem os chamados Cursos de Integração, um combinado de aulas de idioma e de conhecimentos gerais sobre a sociedade alemã. Num trabalho interdisciplinar, com contribuições da história oral (Alberti, 2000), conduzi entrevistas com as participantes da pesquisa para gerar os dados para a análise. Transcritas as entrevistas, realizei algo que me permito chamar, retrospectivamente, de análise discursiva quase intuitiva, ainda muito incipiente e, por que não dizer, insipiente, não fosse por uma primeira leitura da obra de Martin Reisigl e Ruth Wodak (2005), Discourse and Discrimination: Rhetorics of Racism and Antisemitism, e do livro de van Dijk (1987), Communicating racism: ethnic prejudice in thought and talk. Concluído o curso e findo aquele ano, despedi-me de Jena e das/os colegas e amigas/os dos quatro anos em que lá vivemos, estudamos e trabalhamos. Antes disso, devo ter mencionado a minha professora de teoria literária, Claudia Hammerschmidt, 
meu interesse pela Análise de Discurso Crítica como projeto de futuro, pois como presente de despedida recebi dela o livro Kritische Diskursanalyse: eine Einführung, de Siegfried Jäger.

De volta ao Brasil, em 2008, comecei a trabalhar como professora de alemão em Brasília, com planos de procurar algum grupo de pesquisa em que pudesse me envolver na Universidade de Brasília, para mim à época também, de certa forma, uma terra estrangeira. Entretanto, antes de chegar à universidade, cheguei à maternidade, e essa experiência foi o que se pode chamar de fase inicial da pesquisa, dos estudos, cujos resultados (apenas parciais, sempre) apresento nesta tese. Durante os períodos de duas gestações, do intervalo entre elas, e até bem recentemente, no final de 2015, realizei uma observação participante - inicialmente, ainda sem um interesse definido enquanto pesquisa acadêmica, no período entre 2008 e o início de 2010, mas pesquisando e observando intensamente, enquanto mulher, sobre as possibilidades ligadas a sua vida sexual e reprodutiva, especificamente no que diz respeito à gestação, ao parto e o acesso à assistência adequada nesse período ${ }^{10}$. Foi aí que se abriu para mim, tomando emprestadas as palavras de minha colaboradora Tânia, a "portinha do universo do parto humanizado" e com ela também a do universo do parto "desumanizado", ou da violência obstétrica, termo técnico que conheci como participante da III Conferência Internacional sobre Humanização do Parto e Nascimento, realizada em Brasília, com a participação de quase 2000 participantes de 26 países, quando Janaína Aguiar apresentou sua tese de doutorado, Violência institucional em maternidades públicas: hostilidade ao invés de acolhimento como uma questão de gênero (Aguiar, 2010).

Relato tudo isso para dizer que a etnografia, constitutiva de minha abordagem, antes que intenção metodológica inicial, foi se concretizando organicamente, fruto de minha experiência pessoal, para então se desenvolver paulatinamente para uma sistematização intencional e planejada, no âmbito da pesquisa acadêmica aqui apresentada. Independentemente de qualquer decisão metodológica posterior, minha abordagem já se caracterizava, inevitavelmente, pela participação e pela observação, por uma pesquisa. Sobre a etnografia e a observação

\footnotetext{
10 Embora seja possível argumentar que observação participante seja algo, em princípio, distinto da experiência pessoal de uma vivência fora do intento acadêmico pré-determinado, acredito sim ser possível reconhecer nessa mesma experiência os traços característicos necessários para denominá-la a posteriori como correspondente a uma observação participante, especialmente no caso em pauta, quando a mulher em questão, no caso eu, já se identificava àquela altura também por um histórico de estudos e pesquisas acadêmicas que indubitavelmente influenciavam também sua maneira de interagir com o mundo fora da academia, visto que a mulher gestante que frequentava o grupo não se poderia dissociar da pesquisadora que era. Enfatizo isso, contudo, também por defender que a linha de separação entre as práticas consideradas acadêmicas e as práticas não acadêmicas pode ser mais tênue do que acreditamos.
} 
participante, é importante, entre outras coisas ressaltar que se inserem numa tradição de pesquisa qualitativa. Antes de seguir contando a história da pesquisa, abro um parêntese para explicitar cada um desses conceitos, conforme assumidos para este estudo.

\subsubsection{Da pesquisa qualitativa e o interesse pelo "mundo lá fora".}

Sobre a pesquisa qualitativa, Angrosino (2009) ressalta a falta de uma definição única e universalmente aceita, pois segundo ele a pesquisa qualitativa teria "várias identidades". Entretanto, existiriam sim traços comuns a essas diversas identidades que permitiram reconhecê-las todas como pesquisa qualitativa. Um deles seria o fato de haver o interesse "pelo mundo lá fora”, ou seja, além dos muros das universidades ou dos laboratórios, tentando conhecê-lo, analisá-lo “de dentro". Também é característico de pesquisas qualitativas a abertura para conhecer particularidades de uma determinada questão, sem a urgência pela generalização dos resultados. Essencial para mim, na definição da pesquisa qualitativa, é a possibilidade de se abster "de estabelecer um conceito bem definido daquilo que se estuda" ou "de formular hipóteses no início para depois testá-las” (Flick, 2009a, p. 9). Essa definição pode e deve acontecer como resultado de uma abordagem de pesquisa aberta, dialógica e reflexiva, que permita adequar métodos e teorias ao que se estuda, e não o contrário. Ademais, sobre as/os pesquisadoras/es, Angrosino (2009, p. 9) ressalta sua importância, "seja em termos de sua própria presença pessoal na condição de pesquisadores, seja em termos de suas experiências no campo e com a capacidade de reflexão que trazem ao todo, como membros do campo que se está estudando". Talvez por isso mesmo a pesquisa etnográfica e a observação participante desempenhem um papel fundamental em pesquisas qualitativas. Sobre isso, Uwe Flick (2009b, p. 13) acredita que

\footnotetext{
Muito do que se sabe sobre relações de campo, sobre abertura e direcionamento rumo a um campo e seus membros, sabe-se através da pesquisa etnográfica. Embora ela seja estreitamente ligada ao método da observação participante, [...] a etnografia sempre inclui vários métodos de coleta de dados. Com bastante frequência encontramos uma combinação de observação, participação, entrevistas mais ou menos formais, uso de documentos e outros traços de eventos na etnografia.
}

Com relação à pesquisa em pauta, essa variedade metódica é muito característica, pois além da observação participante, realizada durante uma profunda imersão, uma vivência que me qualifica antes como uma participante pesquisadora, que como uma pesquisadora participante da prática social em foco, todas essas formas de coleta e de geração de dados foram úteis na 
composição do que chamo, apoiada em Margarete e Siegfried Jäger (1996, 2012), base material ${ }^{11}$ da pesquisa. Para dar conta do registro das informações obtidas durante a observação participante, foram redigidas notas de campo. Segundo Angrosino (2009, p. 59), essas notas devem conter descrições do cenário da observação, dos participantes e seus comportamentos e interações, assim como uma cronologia dos eventos e o registro das conversas e outras interações verbais. Daí resultou um extenso arquivo com anotações, sobre observações presenciais e seus contextos, e print screens dos ambientes virtuais nos quais acessava parte de meus dados.

2.1.2. Da etnografia à netnografia: do presencial ao virtual.

Sobre a etnografia, Angrosino (2009, p. 16) ainda escreve que significa literalmente "descrição de um povo", ou seja:

uma maneira de estudar pessoas em grupos organizados, duradouros, que podem ser chamados de comunidades, ou sociedades. O modo de vida peculiar que caracteriza um grupo é entendido como sua cultura. Estudar a cultura envolve um exame dos comportamentos, costumes e crenças aprendidos e compartilhados do grupo.

Os primeiros estudos chamados etnográficos aconteceram na virada do século XIX para o XX, e o foco estava voltado para sociedades ou comunidades consideradas culturalmente distantes das/os pesquisadoras/es. Entretanto, a chamada Escola de Chicago trouxe os métodos da etnografia para a pesquisa de comunidades "modernas" nos Estados Unidos (Bogdan \& Biklen, 2003 apud Angrosino, 2009, p. 17). No que diz respeito a seu desenvolvimento posterior, Angrosino (2009, p. 27) comenta a influência das abordagens teóricas interdisciplinares na etnografia mencionando, entre outras áreas, a teoria crítica e os estudos culturais. Sobre a teoria crítica, relembra o foco no "uso da ciência social para desafiar os pressupostos das instituições dominantes da sociedade", se distanciando veementemente do pressuposto da neutralidade da/o pesquisador/a. Sobre os estudos culturais, uma vertente da teoria crítica, Angrosino (2009, p. 28) ressalta a autorreflexividade característica da/o pesquisador/a, já que, diferentemente das/os etnógrafas/os tradicionais (que, "de certa maneira, eram não pessoas - como se fossem extensões de seus gravadores"), seriam, ao contrário, "hiperconscientes de suas próprias biografias, que são consideradas como partes legítimas do estudo”. Menciono isso para justificar minha decisão de explicitar neste capítulo metodológico não só os caminhos internos

\footnotetext{
${ }^{11}$ Um dossiê a ser estabelecido recursiva e progressivamente durante cada projeto (S. Jäger, 2012).
} 
da pesquisa, mas também o contexto biográfico em que se insere, além de ressaltar minha subscrição à teoria crítica, à ADC que, como ressalta Siegfried Jäger (2012, p. 11), pode ser entendida "como uma seção dos estudos culturais, que se definem, em princípio, como contextualmente situados, teoricamente embasados, intervencionistas, inter e transdisciplinares além de autorreflexivos".

De qualquer forma, é importante ressaltar que a etnografia, como Hammersley (2005) sugere assim como podemos afirmar para a pesquisa qualitativa - é um termo "guarda-chuva", que vem sendo, segundo esse mesmo autor, delineado e marcado pelo uso, adquirindo formas diversas dependendo do contexto disciplinar em que é aplicado. O mais comum hoje em dia seria etnógrafas/os dedicarem uma atenção especial à língua utilizada pelas pessoas enquanto vivem ou descrevem suas vidas, de forma a buscar compreender de que maneira essas pessoas agem por meio da língua em uma constante construção discursiva dos fenômenos sociais característicos da sociedade na qual estão inseridos (Hammersley, 2005, p. 5). Seguindo sua argumentação, Hammersley defende que, embora em suas origens a etnografia implicasse uma imersão integral na comunidade estudada, atualmente seria recorrente a prática de pesquisa que envolva alguma participação ou ainda apenas a realização de algumas entrevistas ser reconhecida como etnográfica.

Além disso, esse autor reconhece outra mudança, ou atualização referente à pesquisa etnográfica: a chamada etnografia virtual ou netnografia, cuja abordagem considera a rede mundial de computadores, ou as redes sociais virtuais, como possíveis equivalentes ao campo de pesquisa empírica. Sobre a netnografia, Dominguez et al. (2007) defendem estarem

[a]s várias maneiras de conceituar a etnografia virtual [...] associadas a uma reflexão sobre a formação cultural da internet e sobre o diálogo de experiências e interações sociais com esse pano de fundo cultural. A Internet é um lugar rico em interações sociais, onde a prática, os significados e as identidades culturais estão interligados através de vários canais. As formas de relação social no cenário virtual representam um desafio para os pesquisadores sociais e abrem novos campos para a análise no campo da metodologia qualitativa.

Além da imersão presencial em comunidades relacionadas ao parto ou a reflexão e busca referentes à assistência obstétrica, eu também participo desde 2008 de fóruns e listas virtuais de discussão sobre esse tema, acompanhando também, cotidianamente, as publicações feitas em redes sociais virtuais mais abertas e de maior alcance, como tem sido o Facebook. Assim posso afirmar que minha pesquisa, além de um caráter etnográfico, também se caracteriza por 
uma dose considerável de netnografia, ambas como forma de vivência, observação empírica, espaços para coleta e geração de dados.

\subsubsection{Inserção da pesquisadora na pesquisa e indicações sociométricas.}

Baseando-se numa "etnografia do fazer etnográfico", Angrosino (2009, p. 21) apresenta, ao comentar a influência do interacionismo simbólico na etnografia, um continuum distributivo baseado no grau de inserção da/o pesquisador/a na 'comunidade pesquisada', assim como no grau de conhecimento dos membros da comunidade sobre os objetivos da pesquisa. Dentre os tipos apresentados, menciono dois que ajudam a caracterizar a etnografia desenvolvida durante o estudo em pauta. Angrosino cita a/o participante completa/o e a/o participante-comoobservador/a. No primeiro caso, a/pesquisador/a estaria totalmente imersa/o na comunidade e não divulgaria sua agenda de pesquisa e, no segundo caso, a/ pesquisador/a estaria imersa/o na comunidade, que saberia de sua pesquisa e daria autorização para seu desenvolvimento. Com relação a minha atuação, posso dizer que inicialmente fui uma participante completa que paulatinamente transformada em uma participante-como-observadora, com objetivos de pesquisa primeiro reconhecidos e em seguida compartilhados juntamente com o convite à colaboração, que resultou tanto na coleta autorizada, quanto na geração de dados especificamente como resposta positiva ao convite feito. O ponto de partida para esse fazer etnográfico foi o já mencionado Grupo de Gestantes do HUB (Hospital Universitário de Brasília), que promove encontros semanais abertos à comunidade, nos quais se oferece orientação e apoio a mulheres e casais grávidos. Frequentei esse grupo desde a sétima semana da minha primeira gestação, cujo desfecho foi um parto vaginal na Casa de Partos de São Sebastião, a única do gênero no Distrito Federal. Durante a elaboração de meu projeto de pesquisa, em 2010, pretendia que esses encontros semanais fossem o espaço principal de minha observação participante e ponto de partida para as indicações sociométricas (Milroy, 2008), na detecção das redes sociais a serem abordadas. Essas indicações sociométricas são definidas por Milroy (2008, p. 549) como a nomeação, por parte das/os colaboradoras/es de pesquisa, de outras/os possíveis interlocutoras/es para a pesquisadora, que teria assim maiores chances de aceitação por ter sido indicada por alguém. Tal técnica tanto facilitaria a abordagem de novas/os colaboradoras/es, como ajudaria a identificar as redes sociais de influência em torno da questão estudada. $\mathrm{O}$ importante é que essas redes sociais constituam comunidades de prática, ou seja, um agrupamento de pessoas em torno de uma questão específica, de um problema comum do cotidiano, e que nessas comunidades de prática os significados sociais sejam co-construídos (cf. Eckert, 2000 apud Milroy, 2008, p. 553). O essencial nessa forma de reconhecimento de 
rede de colaboradoras/es é que se trabalha com uma unidade social pré-existente e autodefinida, independentemente de um recorte prévio e artificial realizado externamente ao grupo, pela/o pesquisador/a.

Com relação a essa indicação, posso reafirmar que o grupo do HUB foi, especialmente nos anos iniciais, o espaço principal de minha vivência e observação participante. Nesses encontros, pude estabelecer vínculos pessoais e me aprofundar na temática relacionada ao parto, ao nascimento e à assistência. Embora isso ainda não fosse para mim previsível no início da pesquisa, a participação em redes sociais virtuais, especialmente no Facebook ${ }^{12}$, foi essencial para o estreitamento de relações e para a concretização dessa indicação sociométrica quase que automaticamente, pois "amigas/os" virtuais, ao compartilhar postagens de outras pessoas envolvidas com a temática, fomentam, mesmo sem querer, a inserção da pesquisadora e o seu reconhecimento por parte das redes discursivas relacionadas ao nascimento e ao parto, que se reproduzem, expõem e mesmo intensificam ao serem transportadas para ou expandidas no ambiente virtual, uma nova ágora de atuação para as ações coletivas.

As indicações sociométricas que aí se iniciaram se desdobraram da presencialidade do tête-àtête para a virtualidade de redes sociais, onde me foi possível participar, observando, em tempo real, não somente local, mas mesmo nacional e internacionalmente, esse movimento pela emancipação da mulher, pelo fim da violência obstétrica e pelo direito de nascer/parir com uma assistência digna e respeitosa. Entendo que, aplicada ao estudo em questão, o vínculo era estabelecido, muitas vezes, pela sensação de pertencimento gerada entre as mulheres pelo fato de serem membros de uma mesma lista de discussão, cujas administradoras eram, em um dos casos, estudantes bolsistas participantes no projeto de extensão do Grupo do HUB. No caso de redes virtuais como o Facebook, a lista de amigas/os (em comum) também favorece uma identificação positiva entre mulheres associadas em torno da campanha pela humanização do parto e do nascimento.

12 Facebook é um site e serviço de rede social que foi lançado em 4 de fevereiro de 2004 e que atingiu a marca de 1 bilhão de usuárias/os ativas/os, sendo por isso a maior rede social em todo o mundo. No site, as/os usuárias/os devem se registrar e podem criar um perfil pessoal, adicionar outros usuários como amigos e trocar mensagens, incluindo notificações automáticas quando atualizarem o seu perfil. Além disso, os usuários podem participar de grupos de interesse comum de outros utilizadores, organizados por escola, trabalho ou faculdade, ou outras características, e categorizar seus amigos em listas como "as pessoas do trabalho" ou "amigos íntimos". (Fonte: Wikipedia) 
2.1.4. Da Análise de Discurso Crítica como possibilidade de pesquisa qualitativa.

Com relação à análise de dados qualitativos, Flick (2009, p. 13) observa que, embora haja diferentes abordagens para a análise de dados qualitativos, "todas elas têm em comum o fato de serem baseadas em análise textual”. Esse fato é fundamental nesta pesquisa por ser o aspecto que permite vincular, ou mesmo, inserir a abordagem etnográfica no marco teórico circundante que orienta o estudo: a Análise de Discurso Crítica. Para falar sobre ela, volto a contar um pouco sobre a história que me trouxe até aqui.

Em 2010, quase um ano após o meu primeiro parto e ainda bastante mergulhada nas novidades e exigências que a maternidade apresenta, especialmente, a 'marinheiras de primeira viagem', ainda muito envolvida com as questões do parto e do nascimento, e estudando para um concurso, precisei reler sobre estudos textuais e me deparei mais uma vez com os estudos do discurso. Tendo lido tantos textos sobre o parto e o nascimento, tanto artigos midiáticos tradicionais, quanto postagens de blogs e, especialmente, relatos de parto, pensei na possibilidade de vir a retomar a pesquisa acadêmica, quiçá, com um projeto de doutorado no âmbito dos estudos do discurso. Foi quando procurei a professora Cibele Brandão, àquela altura ministrando uma disciplina intitulada Metodologia: Análise de Discurso e Pesquisa Etnográfica, que me recebeu de uma maneira muito acolhedora no curso já em andamento, possibilitando-me a leitura compartilhada de textos sobre etnografia, estudos culturais, pragmática e análise de discurso crítica. Sabendo de meu especial interesse por essa abordagem específica, a professora me avisou que no dia seguinte haveria um encontro no NELiS (Núcleo de Estudos Linguagem e Sociedade), em que seria discutido, no âmbito de um Ciclo de Estudos sobre Métodos para Análise Discursiva de Textos, um capítulo do livro de Theo van Leeuwen (2008), Discourse and Practice: New Tools for Critical Analysis.

Munida com uma cópia do capítulo, fui ao encontro com o receio de quem (ainda) não pertence ao grupo, torcendo para que pelo menos a professora Cibele chegasse antes de mim e que com isso eu me sentisse menos constrangida. Lá chegando, não encontrei Cibele, mas duas estudantes muito atenciosas já estavam lá e foram muito simpáticas e acolhedoras, Andreia Santos e Gissele Alves. Atendendo a meu pedido, me indicaram uma possível orientadora, uma professora que chegaria dali a pouco, da área de Análise de Discurso Crítica, Viviane Resende. Ao término do encontro, procurei a professora, disse que voltava à UnB após muitos anos afastada e, corajosa, ainda que timidamente, perguntei-lhe se achava plausível a ideia de pesquisar sobre o parto no âmbito da ADC. Com grande alegria ouvi uma enfática resposta 
positiva, seguida da observação de que, inclusive, uma professora da casa já havia escrito uma tese com uma proposta assim, que eu procurasse a tese de doutoramento de Juliana Dias. E esse foi o primeiro de muitos outros encontros de orientação que aconteceriam ao longo dos últimos seis anos.

No semestre seguinte, ainda como aluna especial, buscando conhecer a perspectiva adotada na linha de pesquisa Discursos, Representações Sociais e Textos, da área de concentração Linguagem e Sociedade, do Programa de Pós-graduação em Linguística, cursei duas disciplinas, e devido a isso li, entre outras coisas, as obras Analysing discourse: Textual Analysis for Social Research, de Norman Fairclough (2003), e também Discourse in late modernity: rethinking critical discourse analysis, de Lilie Chouliaraki \& Norman Fairclough (1999). Ambas as obras foram basilares para o desenvolvimento do meu projeto inicial, com o objetivo de investigar, numa perspectiva crítica da prática de pesquisa, a ação, a representação e a identificação de sujeitos interligados em redes sociais relacionadas ao gestar, ao parir e ao nascer, com a investigação empírica realizada por meio de pesquisa de cunho etnográfico, presencial e virtualmente, e da Análise de Discurso Crítica (ADC) (Chouliaraki \& Fairclough, 1999; Fairclough, 2003), cujas ferramentas me permitiriam investigar sob uma perspectiva crítica, no âmbito da Linguística, com o foco imediato em uma questão social - no caso, a violência obstétrica e também a resistência das mulheres. Essa perspectiva pressupõe, como já mencionado, uma postura científica comprometida com a mudança social e a pesquisa realizada por um/a pesquisador/a reflexiva/o, que não parte de pressupostos de neutralidade científica, mas sim da inevitável subjetividade a influenciar todos os seus passos, buscando dar transparência a sua prática de pesquisa também no que diz respeito a essa subjetividade.

As obras citadas de Chouliaraki \& Fairclough (1999) e Fairclough (2003) versam sobre como a linguística enquanto disciplina pode contribuir, por meio da análise textual, para o estudo crítico de questões sociais. Fairclough (2003, p. 2), cuja proposta é chamada de análise do discurso textualmente orientada, defende que essa versão de ADC

se baseia no pressuposto de que língua é uma parte irredutível da vida social, dialeticamente interconectada com outros elementos da vida social, de forma que a análise e a pesquisa social têm de levar em conta a questão da língua. Isso significa que uma maneira produtiva de se fazer pesquisa social é por meio de um foco na linguagem, utilizando-se alguma forma de análise do discurso. [...] e muitas vezes faz sentido utilizar a análise do discurso em conjunção com outras formas de análise, por exemplo, a etnografia ou formas de análise institucional. 
A análise textual é vista, nessa abordagem, como meio de acesso ao momento da prática social, ao qual subjazem discursos que se materializam em textos, tornando-se assim acessíveis à/o pesquisador/a, que pode, por meio de sua análise, identificar efeitos de poder desses mesmos textos. O que mais especificamente caracteriza a ADC, diferenciando-a da análise meramente linguística, é sua proposta de transdisciplinaridade como potencial e seu declarado compromisso com a mudança social.

2.2. "Muito parto e pouca linguística". Da negativa que me levou de volta a Jena e a Duisburg.

Com uma das primeiras versões do projeto, candidatei-me, no final de 2010, a uma vaga como aluna de doutorado no PPGL da UnB, mas não tive meu projeto aceito, sendo que um dos motivos alegados no parecer negativo da presidenta da comissão de seleção era o fato de minha proposta falar "muito de parto e pouco de linguística". Não sei se meu projeto seria um desses casos, mas fato é que, como escreve Resende (2013, p. 338),

[é] verdade [...] que no amplo campo da Linguística há até hoje certa resistência aos estudos críticos do discurso. Ainda hoje ouvimos colegas linguistas levantar dúvidas sobre a cientificidade de nosso trabalho e sobre nosso engajamento com a Ciência Linguística. Creio que essa é uma dificuldade comum a todos os campos de estudo que ousam cruzar fronteiras disciplinares. [...] Sem dúvidas, não há nada de fácil no cruzamento de fronteiras disciplinares, e na ADC não é diferente.

De qualquer maneira, foi com tristeza que recebi a negativa, sabendo que por razões familiares não estaria em Brasília para poder me submeter ao próximo processo de seleção. Portanto não estava mais no meu horizonte, pelos dois anos seguintes, a possibilidade de estar regularmente matriculada como aluna de doutorado na UnB. Esse foi o motivo que me levou, determinada a realizar esta pesquisa, de volta à FSU com o mesmo projeto, para apresentar minha candidatura a uma vaga como estudante de doutorado. Lá fui aceita, ainda em 2010 e já gestante de minha segunda filha. Embora oficialmente matriculada em Jena, continuava cursando disciplinas na UnB, como aluna especial, e contando com a valiosa orientação de Viviane Resende. Assim, quando no segundo semestre de 2011 passei seis meses em Jena, devido a uma estada de pesquisa de meu companheiro, também frequentei os seminários de pesquisa organizados por minha orientadora alemã, Claudia Hammerschmidt, e descobri a possibilidade de realizar a pesquisa num doutoramento binacional. Depois de um ano inteiro de intermediação e lida com a burocracia das duas instituições, o apoio sine qua non das duas orientadoras e a aprovação do colegiado do PPGL da UnB e da Conselho da Faculdade de Filosofia da FSU Jena, conseguimos 
assinar o termo de cooperação para a realização de um doutorado binacional em regime de cotutela, orientado igualitariamente pelas professoras Claudia Hammerschmidt e Viviane Resende. Então, regularmente matriculada como doutoranda do Programa de Pós-Graduação em Linguística na Universidade de Brasília, pude ser contemplada como uma bolsa de estudos CAPES/Reuni ${ }^{13}$. O doutoramento em regime de cotutela implicava, entre outras coisas, a necessidade de que eu passasse pelo menos mais um ano em Jena, além do cumprimento de todas as exigências do PPGL. Portanto, e graças a uma bolsa de estudos do Programa Conjunto de Bolsas de Doutorado na República Federal da Alemanha Seleção 2013/2014, CAPES/CNPq/DAAD, passei todo o ano de 2014 naquele país. Período no qual tive a oportunidade de me (re)aproximar de outra abordagem que se tornou estruturante para minha pesquisa, nomeadamente a abordagem de análise de discurso crítica da Escola de Duisburg, a mesma do autor do livro que levara de presente para casa quando me despedi da Alemanha no final de 2007.

Nesse ano de 2014, estive duas vezes no Instituto de Pesquisa Social e Linguística de Duisburg (DISS). Na primeira vez, em maio, estive visitando e acompanhando minha orientadora Viviane Resende, que foi convidada a apresentar as pesquisas desenvolvidas no NELiS, na UnB, e se reunir com as/os pesquisadoras/es do Instituto para conversar sobre a possibilidade de cooperação entre o NELiS e o DISS. Na ocasião fomos recebidas por Margarete Jäger, atual diretora do DISS, que nos presenteou com o livro resultante de sua tese doutoral, Fatale Effekte: Die Kritik vom Patriarchat im Einwanderungsdiskurs (1996), e me convidou a voltar, no segundo semestre, para participar em um dos encontros da Diskurswerkstatt (Oficina de Discurso) expondo minha pesquisa em andamento. Esse compromisso me motivou a me debruçar sobre os estudos publicados pelo DISS, especialmente sobre a obra de Margarete, na tentativa de perceber como suas contribuições poderiam servir a meu projeto de pesquisa, para que pudesse enfim, em outubro de 2014, voltar ao DISS, aplicando sua abordagem e tendo a oportunidade ouvir suas críticas e sugestões para o futuro andamento do trabalho.

Fundamental para mim na ADC é a visão segundo a qual o trabalho de pesquisa não deva partir meramente de interesses acadêmicos, mas sim indagar como um problema social é expresso, sinalizado, constituído e legitimado no discurso (Wodak, 2004, p. 225 apud Ramalho \&

13 Programa de Apoio a Planos de Reestruturação e Expansão das Universidades Federais, instituído pelo Decreto $\mathrm{N}^{\circ}$ 6.096, de abril de 2007, durante o segundo mandato do Presidente Luís Inácio Lula da Silva, entre outras medidas, com a implementação de bolsas de pós-graduação condicionadas à preparação da/o bolsista para o exercício da docência no ensino superior. 
Resende, 2011, p. 20). A Escola de Duisburg significa para mim tanto um enquadre teóricometodológico necessário e pragmático, quanto um modelo exemplar de pesquisa engajada e política, na qual o problema social em questão está sempre em primeiro plano. Sua pesquisa engajada e declaradamente política, com foco em problemas sociais como o racismo, questões de gênero e a desigualdade social na Alemanha são para mim, que vivi oito anos da minha vida como mulher negra imigrante naquele país, um modelo sobre como é possível, desde uma posição discursiva privilegiada, valer-se dela e dos recursos materiais e simbólicos a ela associados num empenho por um mundo melhor. Note-se que em sua introdução à ADC, Siegfried Jäger (2012, p. 9) ressalta que além de uma obra didática e de referência teórica, o livro apresenta-se como um texto político, com o objetivo de orientar novas possibilidade de ação política e resistência contra toda e qualquer forma de dominação entre seres humanos. Conhecer sua obra, estar com elas e eles no DISS e observar sua prática acadêmica também em eventos científicos, característicos pela composição plural do público e das/os palestrantes, claramente voltados a um diálogo horizontal entre diferentes grupos sociais e diferentes gerações, de acadêmicas/os e ativistas, me fez reconhecer em seu projeto uma genuína coerência entre teoria e prática, algo que almejo também para minha própria trajetória de pesquisa. Portanto, numa escolha cuja motivação, além de metódica, também é política, (re)estruturei meu trabalho de acordo com a proposta de organização da pesquisa apresentada por Margarete Jäger, buscando estabelecer pontes com outras propostas, como a faircloughiana, sempre que isso me pareceu necessário, também de forma a reconhecer o legado e recordar ter sido essa, a escola inglesa, a porta de entrada para a pesquisa que ora apresento.

Refletindo epistemologicamente sobre todo esse trabalho de pesquisa e no âmbito mesmo em que se insere academicamente, acho muito válidas também as reflexões apresentadas por Grossfoguel (2016, p. 25), ao discutir a estrutura do conhecimento nas universidades ocidentalizadas e recordar o racismo e o sexismo epistêmico nessas instituições, que além de gerar injustiças cognitivas são mecanismos de sustentação de projetos imperiais, coloniais e patriarcais de dominação. Segundo ele

[o] racismo/sexismo epistêmico é um dos problemas mais importantes do mundo contemporâneo. O privilégio epistêmico dos homens ocidentais sobre o conhecimento produzido por outros corpos políticos e geopolíticas do conhecimento tem gerado não somente injustiça cognitiva, senão que tem sido um dos mecanismos usados para privilegiar projetos imperiais/coloniais/ patriarcais no mundo. A inferiorização dos conhecimentos produzidos por homens e mulheres de todo o planeta (incluindo as mulheres ocidentais) tem dotado os homens ocidentais do privilégio epistêmico de definir o que é 
verdade, o que é a realidade e o que é melhor para os demais. Essa legitimidade e esse monopólio do conhecimento dos homens ocidentais têm gerado estruturas e instituições que produzem o racismo/sexismo epistêmico, desqualificando outros conhecimentos e outras vozes críticas frente aos projetos imperiais/coloniais/patriarcais que regem o sistema-mundo.

Embora considere legítima a proposição de Grossfoguel, também concordo com Resende (2013, p. 343) quando defende que não se trata de simplesmente negar o legado, mas importante seria a vigilância quanto à adequação das propostas a que aderimos, muitas vezes sem a devida atitude reflexiva e questionadora:

Não é o caso de perdermos tempo negando o legado europeu ou questionando a validade de teorias pelo simples fato de serem importadas - não, ao contrário: devemos nos aproveitar dos recursos já existentes. O que importa é mantermos a vigilância crítica não só da aplicabilidade de teorias e discursos poderosos a nossos contextos locais, mas também da própria coerência interna dessas teorias. E assumirmos a ousadia de propor novas e diferentes reflexões.

Por isso, eu, embora não negue o legado, procuro exercer essa vigilância, selecionando um enquadre que me contemple teórica, metodológica e politicamente, desde uma atitude feminista voltada também ao reconhecimento do trabalho das mulheres atuantes, não somente em ADC, mas em qualquer outra disciplina de que tenha me servido na execução de minha pesquisa.

Com meu projeto inicial buscava, desde o início, para além da discussão meramente teórica ou linguística, contribuir para a produção de conhecimentos que pudessem colaborar nesse empenho coletivo por uma "nova" maneira de parir e de nascer.

Entendo que a relevância social deste trabalho investigativo, analítico e reflexivo, reside sobretudo na solidariedade inscrita neste empenho, que faz eco e amplifica a voz de outras tantas protagonistas de sua própria emancipação e da libertação da posição de sujeito alvo de violência, de uma violência obstétrica institucionalizada e normalizada, um aspecto entre outros na falta de garantia de direitos humanos, sexuais e reprodutivos a que estamos sujeitas as mulheres. Como afirma Melania Amorim ${ }^{14}$, de maneira que também me contempla, "por considerar muito mais importante o protagonismo e um amplo contexto, há muito não me digo mais ativista da 'humanização do parto' mas sim dos 'direitos sexuais e reprodutivos', uma visão mais abrangente."

14 Em postagem de seu perfil pessoal no Facebook, 14 de agosto de 2016. 
Por se tratar de uma abordagem qualitativa, optei desde o início por trabalhar não com hipóteses a serem testadas, ou teses a serem defendidas, mas sim com questões de pesquisas. Não me servi de hipóteses, para evitar o risco de encontrar apenas o que estava procurando e já acreditava saber de antemão. As questões de pesquisa que apresentei não eram retóricas, não demandavam apenas uma confirmação ou uma refutação, mas sim uma resposta ou mais respostas, e quem sabe mesmo novas questões. E, verdade seja dita, as questões iniciais foram se transformando no decurso da investigação, de forma a nortear, sem limitar, a coleta e a geração de dados. Ressalte-se, entretanto, que inversamente também os dados nortearam os questionamentos, que precisaram ser refeitos, de uma nova maneira, a cada avanço do processo investigativo. As questões com as quais finalizo esta tese, então, que muito provavelmente seguiriam se metamorfoseando caso a pesquisa tivesse continuidade, são as seguintes:

(1) Como se identificam as mulheres com respeito ao período pré-natal, ao momento do nascimento e ao pós-parto?

(2) Como é representada/identificada a figura da/o profissional da assistência que a acompanha nesse período/momento?

(3) Como são representados o contexto do pré-natal e do nascimento?

(4) Como se relacionam essas representações/identificações com a conjuntura mais ampla em que elas acontecem ou das quais elas resultam?

(5) Como se (re)produz e/ou se minimiza discursivamente o problema da violência obstétrica considerado o contexto mais amplo em que ela se insere?

Com a etnografia, ou a descrição densa (Geertz, 1989) de um grupo social por meio de imersão e interação da/o pesquisador/a com este grupo, desde uma perspectiva crítica e com um caráter dialógico e colaborativo, busquei conduzir minha pesquisa de forma que ela se desse não entre pesquisadora e informantes (Cameron et al., 1992 apud Resende, 2009, p. 59), mas sim entre colaboradoras/es de pesquisa. Nas interpretações, resultantes de interações entre distintas pessoas e opiniões, ouvidas ou lidas, tenho mantido o esforço de considerar toda a complexidade dos processos sociais sem buscar uma verdade única e homogênea (cf. Angrosino, 2009, p. 28).

Para realização dessa pesquisa dialógica, dialética e colaborativa, fez-se necessária a conjunção de distintas técnicas e triangulações, de forma a garantir um acesso o mais diverso possível à questão estudada. A principal das técnicas de que tenho me utilizado em minha pesquisa tem sido a observação participante, presencial ou virtual. Conforme Agrosino (2009, p. 34), a 
observação participante é na realidade "um contexto comportamental a partir do qual um etnógrafo usa técnicas específicas para coletar dados". O autor fala aqui de contexto comportamental, porque a observação participante diz respeito a um comportamento por parte da/o pesquisador/a, que procura participar da comunidade estudada, de forma a ser aceita/o como um/a de seus membros e colaboradoras/es. Nesse contexto, seria negociada a colaboração na pesquisa, estando todas/os as/os colaboradoras/es - a/o pesquisador/a inclusive - em pé de igualdade e buscando juntas/os gerar os dados a serem interpretados. Um exemplo específico desta atitude nesta pesquisa foi a introdução de um tipo específico de gênero discursivo no corpus analítico, a carta à/o obstetra, após sugestão e oferta de uma colaboradora de pesquisa.

2.3. Os componentes ontológicos do mundo social. Uma ponte entre Realismo Crítico e a ADC.

Antes de continuar, informo que não pretendo com meu trabalho oferecer um levantamento das diversas vertentes de Análise de Discurso Crítica em voga, seja no contexto brasileiro, seja no alemão. Além de tal intento extrapolar os limites estabelecidos para a realização deste estudo, já existem vários trabalhos que dão conta desta tarefa de maneira satisfatória (Magalhães, 2005, Resende \& Ramalho, 2006, Resende, 2009, Ramalho \& Resende, 2011, Keller et al. 2011, Wodak \& Meyer, 2015). Pretendo, sim, ater-me à abordagem selecionada, por atender os interesses específicos desta pesquisa, e às contribuições que se fizeram necessárias no decorrer do percurso. E faço isso partindo de uma reflexão sobre a ontologia que orienta esta pesquisa.

Margarete Jäger, co-fundadora e atual diretora do Instituto de Pesquisa Linguística e Social de Duisburg (DISS), iniciado em 1987, defendeu em 1995 sua tese doutoral, que versa sobre a etnização do sexismo no discurso cotidiano sobre a imigração na Alemanha. Antes disso, ainda em 1988, publicou em coautoria com Siegfried Jäger, então professor titular da Universidade de Duisburg, o livro Gewalt gegen Frauen - durch Sprache? (Violência contra a mulher - por meio da língua?). E desde então foi autora e co-autora em inúmeros projetos de pesquisa e discussão teórica em Análise de Discurso Crítica de orientação foucaultiana, contribuindo para a atualização da proposta sempre retroalimentada e atualizada como base em projetos (de intervenção) empíricos. Entretanto, apesar do refinamento realizado com o passar dos anos, a abordagem por ela utilizada já em 1996 continua produtiva para o estudo das facetas discursivas de questões sociais. Também por esse motivo, parto de sua proposta de análise para dialogar com as contribuições de outras abordagens, aí incluídas as contribuições de analistas locais no contexto brasileiro. 
Conforme Resende (2009, p. 19), a "ontologia diz respeito ao modo como se entende a natureza social, aos componentes essenciais da realidade social". Em minha pesquisa, considero os seguintes componentes ontológicos, sobre os quais discutirei detalhadamente a seguir: estrutura social, prática social, ação social, dispositivo, discursos, posição discursiva.

Em sua obra Análise de Discurso Crítica e Realismo Crítico, Resende (2009) aponta as contribuições do Realismo Crítico (Bhaskar, 1989) para definição da ontologia do mundo social em pesquisas discursivas. Especialmente enriquecedora me parece a proposta de estratificação da realidade em três níveis: o potencial, o realizado e o empírico. Essa estratificação, que reconhece o potencial como parte do real, nos permite afirmar a materialidade das estruturas sociais, "que embora não sejam diretamente observáveis podem ser conhecidas por seus efeitos" (Resende, 2009, p. 21), verificáveis no que foi realizado, desde que por nós acessado empiricamente. A distinção entre o realizado e o empírico ressalta o fato de que, por meio de nossas observações, não necessariamente temos acesso a tudo que foi realizado, da mesma forma que o fato de não ter sido realizado não significa a inexistência de um potencial não realizado, mas estruturado socialmente.

Partindo dessa percepção, Resende propõe que "uma perspectiva das estruturas sociais como objetos reais e como produtos sociais é indispensável à ciência crítica", principalmente se considerarmos a concepção de que as estruturas sociais funcionam como constrangimento, limitando, mas também como recurso, possibilitando, a ação social, que por sua vez tanto pode reproduzir quanto transformar essas estruturas, como prevê o modelo transformacional da atividade social (Bhaskar, 1998 apud Resende, 2009, p. 27). Segundo esse modelo, as estruturas sociais equivalem a um potencial em constrangimento e em possibilidades para possíveis ações sociais, potencial constituído como resultado de ações sociais passadas e que se (re)atualiza a cada nova ação. Essa definição é muito profícua para a pesquisa crítica que visa contribuir para a superação de problemas sociais decorrentes de relações de dominação, pois impede incorrer em erros como o determinismo, segundo o qual não teríamos nenhuma influência na (re)constituição da estruturas que limitam nosso potencial de ação, ou o voluntarismo, segundo o qual teríamos total controle sobre os resultados de nossos empenhos, independentemente de estruturas sociais pré-existentes. Ter isso em mente nos ajuda, por exemplo, a entender por que uma médica convencida da primazia do parto normal pode acabar operando uma parturiente pelo simples fato de estar em um ambiente hospitalar, devido aos constrangimentos estruturais aí vigentes. 
Ainda sobre a interlocução entre ADC e Realismo Crítico, Resende cita Bhaskar (1998 apud Resende, 2009, p. 29-30), que afirma ser necessária uma instância intermediária entre estrutura e a ação social, ou melhor, entre estrutura social e agência humana. Essa instância deveria ser relativamente duradoura e conter posições estáveis, ocupadas por indivíduos no estrato realizado, cuja ação estaria relacionada com as possibilidades e as limitações dessas posições e se realizaria no âmbito de práticas nas quais os indivíduos se engajariam por ocuparem tais posições. Em seu trabalho, seguindo a vertente de ADC faircloughiana, Resende associa essa instância intermediária ao conceito de práticas sociais (Chouliaraki \& Fairclough, 1999; Fairclough, 2003), articuladas em quatro elementos: discursos, relações sociais, fenômenos mentais e atividade material. Não pretendo me ater à discussão mais detalhada sobre os desdobramentos desse conceito, contudo quero dizer que entendo que essas práticas sociais, enquanto formas relativamente duradouras e estáveis de intermediação entre estrutura e ação social, surgem como reação perante necessidades decorrentes da vida, da sobrevivência humana em sociedade. E devido a essa compreensão, permito-me, a partir daqui, associar à instância intermediária proposta pelo realismo crítico ao conceito de dispositivo, cuja utilização na escola de Duisburg se deve à fundamentação teórica de base foucaultiana que os inspira, e também ao conceito de posição discursiva.

Opto por essa mudança, pois, se bem me parecem muito similares as duas sugestões conceituais, qual seja prática social qual seja dispositivo, o desdobramento dessa última me parece menos complexo, sem, contudo, deixar de atender às necessidades da pesquisa em pauta, desde que realizados pequenos ajustes sobre os quais falarei mais adiante. Resende (2009, p. 15) observa ainda que para a ADC faircloughiana são basilares tanto o conceito de prática social quanto o conceito de discurso, sendo que discurso corresponderia apenas a um dos momentos da prática social. O mesmo se pode afirmar sobre a ADC de Duisburg, sendo que a mesma relação se estabelece entre dispositivo e discurso.

No dicionário conceitual de ADC, publicado pelo DISS, Emil Cetin (2010, p. 51) observa que que o conceito dispositivo aparece na obra de Foucault pela primeira vez em 1976, em sua obra A vontade de saber, como "um instrumento de produção de discursos". Segundo essa autora, em uma passagem da obra Dispositive de Macht (Dispositivos de poder), traduzida do francês e publicada em Berlin em 1978, Foucault afirma que o dispositivo corresponde a 
afirmações científicas, doutrinas filosóficas, morais ou filantrópicas, resumindo: o dito e o não dito. [...] uma formação cuja função principal foi atender a uma necessidade a um determinado momento histórico. $\mathrm{O}$ dispositivo tem, portanto, sobretudo uma função estratégica. (Foucault, 1978 apud Cetin, 2010, p. 51-2).

Cetin afirma também que os dispositivos estariam sempre imbricados em uma disputa de poder, seriam estratégias de relações de força que sustentam alguns tipos de saber, ao mesmo tempo em que são sustentados por eles. Dispositivos não existiriam simplesmente, se constituiriam, sim, para atender a demandas sociais historicamente situadas e motivadas. Dito isso, a autora observa que a ADC, em sua vertente alemã, se filia a Foucault no entendimento de que discursos têm efeitos de poder, porque transportam conhecimento - o conhecimento válido em um determinado espaço histórico-geográfico - e também coíbem, impedem e calam conhecimento: tanto obrigam quanto proíbem a expressão de um conhecimento determinado. Essa disposição sobre o conhecimento é constituinte das estruturas sociais, visto que fundamenta, limitando e possibilitando, a ação humana individual e coletiva, também no que diz respeito à manutenção ou desconstrução dessas mesmas estruturas. Entretanto, é importante ressaltar que não se trata apenas do conhecimento dito ou escrito, mas sim de todo o aparato de conhecimento em que se insere esse dizer ou escrever. Assim sendo, o conhecimento repousaria não só no dizer, escrever ou pensar, no aspecto linguístico, mas também no agir e nas produções materiais da ação humana baseada nesse conhecimento. Daí resulta, por fim, o conceito de dispositivo adotado na ADC de Duisburg, um complexo composto por práticas discursivas (fala ou pensamento fundamentado em conhecimento), práticas não-discursivas (ação fundamentada em conhecimento) e visibilidades (produções materiais fundamentadas em conhecimento) (S. Jäger, 2012, p. 73).

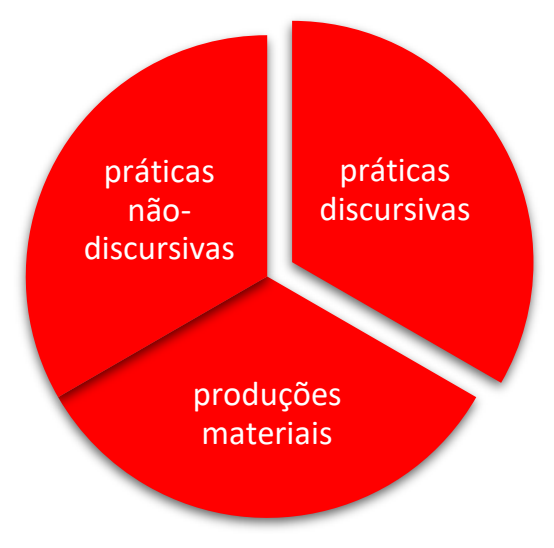


Enfim, defende-se que, na realidade, poderíamos falar de uma análise de dispositivo, caso considerássemos todos esses aspectos, sendo que a análise discursiva crítica corresponderia apenas ao escrutínio das práticas discursivas do dispositivo. Portanto, o discurso seria apenas uma das facetas dessa instância intermediária entre a ação e a estrutura social, e quando falamos de ADC, nos referimos a essa faceta especificamente discursiva, reconhecendo inclusive os limites de nossos estudos, que não dariam conta de todo o dispositivo, e alcançando uma adequação entre epistemologia e ontologia, conforme reclamado por Resende, motivada por Mason (2002 apud Resende 2010, p. 199), quando escreve que

[a] metodologia de planejamento de pesquisa não deve resultar diretamente do campo de pesquisa social ou objetivos iniciais da pesquisa. Esse planejamento deve resultar, sobretudo, da reflexão acerca das perspectivas ontológicas e epistemológicas adotadas. $\mathrm{O}$ modelo epistemológico adotado na pesquisa precisa produzir conhecimento levando em consideração os componentes ontológicos do mundo social, de acordo com a versão ontológica considerado para a pesquisa. Assim, no domínio da investigação, há a necessidade de uma correspondência entre as perspectivas ontológica e epistemológica.

Ainda no intuito de justificar essa associação do dispositivo a uma instancia intermediária, entre estrutura e ação, preciso mencionar a categoria de posição discursiva sugerida por Margarete Jäger (1996, p. 47):

o lugar de onde se dá uma participação no discurso e sua avaliação para uma pessoa ou um grupo ou instituição. [...] $\mathrm{O}$ resultado do envolvimento em diversos discursos, aos quais o indivíduo foi exposto, e, durante sua vida, processou em um determinado posicionamento ideológico ou uma visão de mundo.

Embora Margarete Jäger não relacione essa posição discursiva ao conceito de dispositivo definido pela ADC de base foucaultiana, eu sugiro fazê-lo, mas não sem antes ampliar seu escopo para o lugar de onde pode, potencialmente, dar-se a ação social, individual ou coletiva, e ainda de onde se pode determinar, ou imbuir o valor de reificações, de produtos resultantes da ação humana, numa sociedade. Portanto, entendo que assim ampliado o conceito de posição discursiva deva ser compreendido como constituinte do dispositivo, condicionando e possibilitando as práticas discursivas (falar ou pensar fundamentado em conhecimento), as práticas não-discursivas (agir fundamentado em conhecimento), e visibilidades (produções materiais fundamentadas em conhecimento). Essa compreensão se alinha a concepção apresentada por Bhaskar (1998, p. 216 apud Resende, 2009, p. 29), segundo a qual precisaríamos de um sistema de conceitos mediadores. Um sistema de posições ("lugares, 
funções, regras, tarefas, deveres, direitos") ocupadas por indivíduos e de práticas, nas quais esses indivíduos se engajariam por ocuparem essas posições. Sistema que ele denominou posição-prática.

Assim, retomando a perspectiva ontológica do mundo social aqui adotada, teríamos, numa concepção transformacional da atividade social, a estrutura social, resultando da ação social anterior e constituindo os constrangimentos e os recursos potenciais para a ação social futura, além de uma instância intermediária entre estrutura e ações, os dispositivos, prevendo posições discursivas a partir das quais se atribui a ações, discursos e produções materiais componentes desse mesmo dispositivo seu lugar no (des)ordenamento social. Lembrando que esses dispositivos se constituem como reação a demandas sociais que a ação social provoca, sem com isso deixarem de ser constitutivos dessa mesma ação e da estrutura social, estrutura essa composta por um plural emaranhado de dispositivos diversos. A diversidade de dispositivos depende diretamente da diversidade de demandas sociais geradas pela ação social, marcada pela disputa de poder.

Imagino não ser necessário ressaltar que esses dispositivos não devam ser entendidos como variáveis autônomas sem relações entre si. Reconhecer ou denominar algum aspecto da realidade como dispositivo é sempre uma maneira subjetiva de isolar, analiticamente, algo cujo início, fim ou intersecções com outros elementos não são um dado a priori, mas sempre resultantes de decisões da pesquisadora, sem que com isso seja desconsiderada a existência de outras possibilidades de delimitação. O modelo é simples, como já mencionado, o que facilita sua aplicação para uma aproximação analítica do discurso; entretanto, entendo que qualquer categoria analítica desenvolvida com o objetivo de apreender o mundo social será sempre incompleta e, em certo grau, ineficaz, o que não significa que não possa nos deixar ao menos alguns passos mais próximas/os de nosso objetivo de compreender a realidade social, de forma a podermos agir nos servindo de recursos potenciais disponíveis na estrutura social vigente para suprimir os constrangimentos potenciais que limitam nossa ação presente nessa mesma estrutura social, na disputa hegemônica por uma estrutura social sem injustiças, opressões ou relações de dominação de qualquer sorte.

Continuando a discussão sobre a ontologia do mundo social aqui pressuposta, passo agora a abordar o componente discursivo do dispositivo, o conceito de discurso. Sobre isso, Cetin (2010, p. 41) escreve, no verbete dedicado à prática discursiva no Dicionário de $A D C$, que em sua obra Arqueologia do Saber, publicada em 1969, Foucault ainda separa, rigorosamente, 
prática discursivas de práticas não discursivas, sendo que seu conceito de discurso diz respeito somente à expressão linguística. Segundo ele, discursos não deveriam ser entendido como "um todo composto de símbolos, mas sim como práticas que constituem, sistematicamente, as coisas às quais se referem" (Foucault, 1973, p. 74 apud Cetin, 2010, p. 41). Segundo Cetin, embora Foucault considerasse pouco relevante para o funcionamento do dispositivo a distinção entre a natureza discursiva ou não discursiva de seus componentes, como teria afirmado em uma entrevista, ele considerava importante que o empreendimento analítico contemplasse todos os componentes. Essa seria uma tarefa para a Análise de Dispositivos, cujo núcleo duro e ponto de partida seria a Análise de Discurso, que também na abordagem de Duisburg corresponde à definição encontrada em Resende (2009, p. 7):

A Análise de Discurso Crítica (ADC) define-se sobretudo por estabelecer relações interdisciplinares voltadas para as ciências sociais, a fim de contemplar reflexões acerca da relação entre linguagem e sociedade que não poderiam ser logradas no interior das fronteiras da linguística.

Outro membro fundador do DISS, o professor emérito Siegfried Jäger (2012), em sua introdução à Análise de Discurso Crítica, assevera que a ADC trata de discursos históricos carregados ainda na atualidade com um teor de verdade, analisando-os criticamente, evidenciando suas estratégias e promovendo sua mudança. Desta maneira, a ADC, que é avessa a qualquer forma de violência e a toda forma de dominação de um grupo humano sobre outro, embasa e motiva protestos “encorajando a resistência frente a injustiças e à opressão/dominação e contra bloqueios em relações de conhecimento e poder de toda sorte, o que Foucault descreve como relações de dominação" (S. Jäger, 2012, p. 9). Siegfried Jäger teve a primeira edição de sua obra introdutória à Análise de Discurso Crítica publicada ainda em 1993, e no enfoque desenvolvido e praticado nas pesquisas do DISS desde então o discurso corresponderia a "formas reguladas de fala institucionalizada, na medida em que são fundidas enquanto ações e que, portanto, exercem efeitos de poder (conforme Michel Foucault)" (Link, 1986a, p.71 apud S. Jäger, 2012, p. 26). Ou ainda a "um fluxo de conhecimento através do tempo e do espaço" (S. Jäger, 2012, p. 29). Textos seriam a materialização desse discurso, que por meio deles se torna acessível à analista. Margarete Jäger (1996, p. 21), em Fatale Effekte, descreve o discurso como

formas de falar institucionalizadas, sujeitas a determinadas regras (passíveis de mudança) e que, portanto, exercem efeitos de poder, porque e na medida em que determinam as ações humanas (ver Link 1982b, 1983). Essa versão do discurso se vincula ao conceito de discurso em Michael Foucault, que concebe 
o discurso como o lado linguístico de uma prática discursiva (Link / LinkHeer 1990, p. 90).

Fairclough (2003, p. 26), que também considera que o discurso equivalha a uma maneira compartilhada de conhecer e organizar a experiência humana, diferencia ainda entre um conceito mais abrangente e abstrato de discurso, "língua e outros tipos de semioses como elementos da vida social", e o uso específico, contável e concreto, correspondendo à existência de diferentes discursos como "diferentes maneiras de representar aspectos do mundo". Os Jägers, ao aludir às diferentes maneiras de conhecimento histórica e geograficamente situado e de formas reguladas de fala institucionalizada sobre aspectos do mundo, propõem a categoria de feixe discursivo, um "recorte temático fechado dentro do discurso" (M. Jäger, 1996, p. 31), que se materializa em fragmentos discursivos com temática comum (M. Jäger, 1996, p. 51; Jäger, S. 2012, p. 80). Esses fragmentos corresponderiam "a um texto ou parte de um texto que trata de um determinado tema” (S. Jäger, 2012, p. 80). Se compararmos as duas propostas, teremos algo como a distribuição na Tabela 1, a seguir, considerando que apenas os textos ou fragmentos discursivos fazem parte do domínio do realizado, enquanto discurso e discursos, nas duas propostas, se inserem no plano do potencial, se pensarmos em termos de realismo crítico, enquanto textos analisados compõem o campo do empírico.

Margarete Jäger, em seu texto $O$ quão crítica é a análise de discurso crítica? (no prelo), escreve também que

Discurso [...] diria respeito a forma e conteúdo de enunciados. E sua análise responde, grosso modo, à pergunta sobre o que élfoi, a um determinado tempo, dizivel, como e por quem. Isso significa que, durante a análise, também sempre se tem em mente a pergunta sobre o que não foi ou não é dizível.

Mais adiante no mesmo texto ela continua dizendo que

[e]nunciados são, por assim dizer, elicitados da diversidade das limitadas expressões linguísticas, trata-se de conteúdos homogêneos. Foucault também os caracterizou como "átomos do discurso" (1981, 115ss.). Enunciados não devem, portanto, ser compreendidos como orações, mas sim como um denominador comum de conteúdo, que pode ser abstraído de orações e de textos.

$[\ldots]$

Discursos se apresentam inicialmente como uma multidão de enunciados e campos de enunciados que devem ser desagregados pela análise de discurso.

Enfim, com relação à ontologia, na acepção adotada neste trabalho, concebe-se o mundo social como sendo regulado por estruturas sociais, constituídas como um complexo de dispositivos, 
compostos pelo discurso (componente linguístico do dispositivo), pelo fazer humano não linguístico (interação social não linguística) e por produtos materiais da ação humana baseada em conhecimento, cada qual determinado e regulado por posições discursivas inerentes ao dispositivo. O discurso, o componente linguístico do dispositivo, se compõe por feixes discursivos, em torno de um recorte temático específico, materializáveis em fragmentos discursivos, cuja análise crítica possibilita a elucidação de enunciados, os "átomos do discurso", essas "formas de falar institucionalizadas, sujeitas a determinadas regras (passíveis de mudança) e que, portanto, exercem efeitos de poder, porque, e na medida em que, determinam as ações humanas" (M. Jäger, 1996, p. 21). Esses enunciados seriam, pensando em termos de realismo crítico, uma instância potencial, acessível por meio da análise de componentes empíricos, como são, no caso desta pesquisa, os relatos de parto e as cartas a obstetras.

\begin{tabular}{|c|c|c|c|}
\hline \multicolumn{2}{|r|}{$\begin{array}{c}\text { Norman Fairclough } \\
(2003)\end{array}$} & \multicolumn{2}{|c|}{$\begin{array}{c}\text { Margarete e Siegfried Jäger } \\
(1996,2012, \text { prelo })\end{array}$} \\
\hline discurso & $\begin{array}{l}\text { "língua e outros tipos de } \\
\text { semioses como elementos da } \\
\text { vida social" }\end{array}$ & discurso & $\begin{array}{l}\text { "um fluxo de conhecimento } \\
\text { através do tempo e do } \\
\text { espaço"; "formas de falar } \\
\text { institucionalizadas, sujeitas a } \\
\text { determinadas regras } \\
\text { (passíveis de mudança) e que, } \\
\text { portanto, exercem efeitos de } \\
\text { poder, porque e na medida } \\
\text { em que determinam as ações } \\
\text { humanas" }\end{array}$ \\
\hline discursos & $\begin{array}{l}\text { "diferentes maneiras de } \\
\text { representar aspectos do } \\
\text { mundo" }\end{array}$ & $\begin{array}{l}\text { feixes } \\
\text { discursivos }\end{array}$ & $\begin{array}{l}\text { "recortes temáticos fechados } \\
\text { dentro do discurso" }\end{array}$ \\
\hline \multirow[t]{2}{*}{ texto } & $\begin{array}{l}\text { "qualquer instância de uso da } \\
\text { língua" }\end{array}$ & $\begin{array}{l}\text { fragmento } \\
\text { discursivo }\end{array}$ & $\begin{array}{l}\text { "texto ou parte de um texto } \\
\text { que trata de um determinado } \\
\text { tema" }\end{array}$ \\
\hline & & enunciado & $\begin{array}{l}\text { "denominador comum de } \\
\text { conteúdo, que pode ser } \\
\text { abstraído de orações e de } \\
\text { textos" } \\
\text { "átomos do discurso" }\end{array}$ \\
\hline
\end{tabular}

A questão da representação e da identificação é especialmente trabalhada pela escola anglosaxã e em seu desdobramento no contexto latino-americano. Fairclough (2003, p. 26), em sua definição de discursos, entende que seriam "diferentes maneiras de representar aspectos do mundo", e propõe para a análise discursiva a observação de três significados, o representacional, o identificacional e o acional (Fairclough, 2003, p. 27). Nesta pesquisa foram 
especialmente os três significados. Pois além de (se) representar e (se) identificar, as aoutoras dos relatos e cartas agiam no fluxo discursivo por meio desses gêneros textuais especialmente afetos à prática social do parir e do assistir ou parto. Com relação especificamente ao significado acional, Fairclough (2003, p. 26) assevera que está presente quando estratégias textuais constituem uma maneira de ação em eventos sociais. Pensando em minhas análises, a análise fina da carta de Dandara ${ }^{15}$ foi exemplar enquanto ação, marcada pelo frequente uso de atos ilocutórios (Austin, 1975; Searle, 1999), aqueles que agem no mundo e se realizam ao mesmo tempo em que são verbalizados, por exemplo pelo verbo "agradecer" na fala de Dandara: “Agradeço por ter respeitado a minha fisiologia e a minha dor...". Mas não somente seu texto, todos os componentes do corpus analíticos podem ser compreendidos sob a perspectiva acional.

Com relação ao significado representacional, Fairclough (2003, p. 26, inserção minha) defende que a "representação é claramente uma questão discursiva, e nós podemos distinguir diferentes discursos que podem representar a mesma área do mundo desde diferentes perspectivas e posições." Comparando com a definição de feixe discursivo, podemos afirmar que um feixe discurso, devido a seu recorte temático, apresentará aspectos de diferentes discursos, nessa acepção faircloughiana. O significado identificacional, por sua vez, diria respeito à constituição de distintas formas de ser por meio das estratégias textuais adotadas, ao que Fairclough (2003, p. 26) chama estilo. Importante é ressaltar que embora, para fins analíticos, sejam propostas duas categorias distintas, representação e identificação, os dados empíricos, não raro, realizam ambas as categorias num único passo. Contradições interdiscursivas, por exemplo, entre o discurso da medicalização do parto e o discurso pró parto natural, podem ultrapassar o nível representacional, acarretando também conflitos na construção identitária, de acordo com a dialética entre os significados teorizada por Fairclough (2003, p. 28).

Os discursos, nos termos faircloughianos, incorporam-se em estilos, pois modos particulares de representação da realidade levam a modos particulares de se identificar em relação a essas realidades. Partindo desse pressuposto, mais uma vez, podemos traçar uma ponte entre a proposta teórica da ADC faircloughiana, a da Escola de Duisburg e o conceito de metáfora proposto por Lakoff \& Johnson (2002, p. 45), quando afirmam que "nosso sistema conceitual ordinário, em termos do qual não só pensamos mas também agimos, é fundamentalmente metafórico por natureza." Se associamos as propostas podemos dizer que o discurso

\footnotetext{
${ }^{15}$ Ver Seção 5.2.
} 
corresponde a um "fluxo/rio de conhecimento através do tempo e do espaço" (S. Jäger, 2012, p. 29), que mantém, (re)constitui e inova incessantemente "formas reguladas de fala institucionalizada" (S. Jäger, 2012, p. 29), "o que é ou não dizível a um determinado tempo" (M. Jäger, no prelo), num constante processo metafórico no qual, constantemente, compreendemos ou experienciamos uma coisa em termos de outra (Lakoff \& Johnson, 2002, p. 48), compondo modos particulares de representação da realidade que levam a modos particulares de auto/alteridentificação.

Com relação ao significado identificacional, Fairclough (2003, p. 159) prefere ainda o termo identificação ao invés de identidade, de forma a enfatizar o processo "o modo como as pessoas se identificam e são identificadas por outras", e não uma concepção de identidade como algo dado ou essencialista. Essa também é a abordagem proposta nos estudos culturais e pela afirmação de Hall (2007, p. 106), que contrasta o essencialismo pressuposto no termo identidade com a construção processual pressuposta na denominação identificação:

Em contraste com o "naturalismo" dessa definição [de identidade], a abordagem discursiva vê a identificação como uma construção, um processo nunca completado - como algo sempre em processo. Ela não é nunca, completamente determinada - no sentido de que se pode, sempre, 'ganhá-la" ou "perdê-la"; no sentido de que ela pode ser, sempre, sustentada ou abandonada.

Em minha pesquisa utilizei também as denominações autoidentificação e alteridentificação, no intuito de diferenciar a identificação enquanto representação de si mesma da identificação enquanto representação de outras atrizes ou outros atores sociais.

Outro conceito chave para este estudo é o conceito de poder, visto que os discursos nos interessam justamente por seus efeitos de poder, por delimitarem o campo de ação dos indivíduos em sociedade. Como já foi dito, a ADC da Escola de Duisburg, mas não somente, fundamenta-se nos estudos de Foucault, e Siegfried Jäger chega mesmo a afirmar que, na realidade, poderíamos dizer que a ADC nada mais seria do que uma Teoria do Discurso Aplicada, sendo que por teoria do discurso se entende aqui a totalidade da obra foucaultiana ${ }^{16}$.

\footnotetext{
${ }^{16}$ Com relação a esse posicionamento, entendo que Siegfried Jäger objetiva enfatizar a influência fundamental e fundadora da obra de Foucault na ADC de vertente alemã, sem que isso signifique o desprezo a todas as contribuições teóricas agregadas nos quase trinta anos de pesquisas e discussões teóricas em ADC na Alemanha, e mesmo em outras vertentes. Para mim, sua afirmação é uma forma explícita de reconhecimento do legado e de incentivo ao estudo de Foucault, além de um exercício de humildade, não muito distante do que faz Norman Fairclough (2001, p. 62) ao afirmar que pretende "operacionalizar sua percepção [de Foucault] em métodos reais de análise" discursiva e linguística textualmente orientada.
} 
Portanto, o conceito de poder considerado nessa vertente da ADC também remete a Foucault, por exemplo, quando afirma que

o poder não é uma Instituição, [...] não é uma potencialidade de alguns poderosos. O poder é o nome que se dá a uma complexa situação estratégica em uma sociedade. [...] O poder vem de baixo; isto é, não há, no princípio das relações de poder, e como matriz geral, uma oposição binária e global entre os dominadores e os dominados, dualidade que repercuta de cima para baixo e sobre grupos cada vez mais restritos até as profundezas do corpo social. Devese antes partir do princípio de que as correlações de força múltiplas que se formam e atuam nos aparatos produtivos, nas famílias, nos grupos e instituições individuais, servem de suporte a amplos efeitos de clivagem que atravessam o conjunto do corpo social [...] onde há poder, há resistência e, no entanto, ou melhor, por isso mesmo, a resistência nunca se encontra em posição de exterioridade em relação ao poder. (Foucault, p. 1983, p. 94-96 apud M. Jäger, no prelo)

Assim, ao falar de poder, não se fala em ADC somente do poder hegemônico, possivelmente, corporificado em instituições governamentais, corporações econômicas ou similares. Antes, fala-se das relações de força ativas nas relações sociais cotidianas. Ressalte-se que esse poder é considerado em relação direta com o conhecimento ou o saber, entendido como verdade histórica e situada, sempre passível de questionamento e mudança; transportado pelo fluxo do discurso, ele mesmo sendo um fator de poder, por engendrar comportamentos, atitudes e outros discursos (M. Jäger, no prelo). Foucault defende, entretanto, que saber e poder, assim separados, seriam úteis somente enquanto "esquema analítico"; ontologicamente, entretanto, o que teríamos seria sempre uma unidade saber-poder:

Saber e poder, isso é apenas um esquema analítico. E esse esquema não é composto por duas categorias estranhas uma à outra - o saber de um lado e o poder do outro [...] Pois nada pode se afirmar como elemento de saber, se não estiver em conformidade com um sistema de regras e constrangimentos específicos. [...] em sentido contrário, nada pode funcionar como elemento de poder se não se desdobrar em procedimentos e relações entre meios e fins, que estejam fundados num sistema de saberes. Não se trata, portanto, de descrever o que é saber e o que é poder e como um oprime ou abusa do outro, mas sim de caracterizar um nexo saber-poder, com o qual a aceitabilidade de um sistema se deixa apreender. (Foucault, p. 1992, 32 apud M. Jäger, no prelo)

Essa relação saber-poder importa para a ADC porque o discurso nos interessa especialmente por definir potencialmente as diretrizes para a ação individual, por meio de seus efeitos de poder, sempre embasados em saberes, ou conhecimentos, reconhecidos como válidos por um determinado grupo histórica e geograficamente situado. Como afirma Resende (2009, p. 16), o poder (e eu, apoiada em Gramsci, diria valer também para o conceito de hegemonia), “depende 
da conquista do consenso e não apenas dos recursos para o uso da força" e o "discurso figura como elemento essencial para a sustentação de relações hegemônicas em um dado contexto histórico."

Embora possa-se dizer que todo e qualquer evento social seja marcado discursivamente, Siegfried Jäger (2012, p. 82) propõe o conceito de acontecimento discursivo. Segundo esse autor, trata-se de eventos que têm uma grande repercussão midiática e que, por isso mesmo, podem influenciar a direção e a qualidade do feixe discursivo a que se referem. Identificar acontecimentos discursivos foi um passo importante para a contextualização da conjuntura em que se insere o feixe discursivo central em meu trabalho.

Reconhecendo com Foucault (1973, p. 189 apud S. Jäger, 2012, p. 123) que a totalidade do arquivo discursivo não seria possivelmente descritível, Siegfried Jäger propõe a validade de projeto menores de análise discursiva, cuja limitação seja reconhecida, sem que isso signifique demérito, pois somente a soma de vários pequenos projetos poderia dar conta de uma descrição possível, cada vez mais abrangente, do discurso vigente a uma época, num determinado espaço geográfico. Para tanto, deveria ser definida uma base material, um dossiê a ser estabelecido recursiva e progressivamente durante cada projeto. A constituição dessa base material deve, de acordo com Siegfried Jäger (2012, p. 124), ser entendida como parte do processo analítico, durante o qual se define a razão para que determinado material seja considerado representativo da materialização discursiva do feixe em pauta. Dentre esses textos, então, dessa base material, é selecionado o corpus analítico mais delimitado, que diz respeito aos fragmentos discursivos a serem submetidos à análise estrutural e à análise fina.

$\mathrm{O}$ conceito de base material me pareceu bastante produtivo, pois o que aponto como base material de minha pesquisa foi essencial para a execução das análises estrutural e fina, ampliando as possibilidades de reflexão, algo que um conceito restrito de corpus analítico poderia silenciar. Esse conceito me permitiu contornar, em parte, a situação descrita por Ramalho e Resende (2011, p. 90), sobre o recorte analítico, sem prejuízo para a definição do corpus analítico mais delimitado:

Se por um lado todo recorte carrega a desvantagem do não aproveitamento de parte dos dados gerados - e muitas vezes é preciso excluir da pesquisa temas que seriam também relevantes -, por outro lado traz a vantagem de manter o foco nos problemas da pesquisa. 
Entretanto, também em minha pesquisa, ainda assim, precisei abrir mão de uma série de possíveis caminhos ao delimitar os caminhos que pude seguir, aplicando as categorias analíticas que passo a elencar na próxima seção.

\subsection{Passos e categorias analíticas.}

Nesta seção, apresento passos e categorias analíticas que foram produtivas nesta pesquisa, começando pelos três momentos analíticos propostos por Margarete Jäger (1996): a análise estrutural, a análise fina e a análise sinóptica.

\subsubsection{Análise estrutural, análise fina e análise sinóptica.}

O objetivo da análise, segundo a perspectiva adotada nesta tese, é explicitar os átomos do discurso, ou seja, os enunciados e também seus efeitos de poder. Segundo Margarete Jäger (1996, p. 40), por meio da ADC, o discurso, seu funcionamento e suas consequências se tornariam mais transparentes e compreensíveis, tanto para o indivíduo quanto para a sociedade como um todo, possibilitando uma sensibilização de participantes e envolvidas/os nesse discurso, instrumentalizando-as/os em ações que visem a mudança discursiva e consequentes mudanças nas estruturas sociais vigentes.

Para tanto, Margarete Jäger (1996, no prelo) propõe que, após a definição do feixe discursivo em questão, que só poderia ser definido a partir de uma contextualização, sejam dados três passos analíticos: uma macroanálise, uma microanálise e uma análise sinóptica, que completaria o processo ao relacionar os resultados dos dois primeiros passos. A contextualização prévia seria necessária, pois só ela poderia embasar ou justificar a delimitação do feixe discursivo. Seguindo essa proposta, estruturei minha tese, apresentando um capítulo dedicado à contextualização, e consequente delimitação do feixe discursivo em foco, para em seguida desenvolver a análise estrutural e a microanálise, antes da análise sinóptica.

Sobre a macroanálise, também chamada análise estrutural, Margarete Jäger (no prelo), explica que

atentará sobretudo para o conteúdo do material. A análise estrutural aponta para a explicitação de enunciados e de suas recorrências. Como resultado, podem ser descobertos textos particularmente típicos do feixe discursivo em questão. Esses serão, então, objetos de uma análise fina, com a qual se investigará a estrutura profunda desses mesmos textos, seguindo com o processo de elucidação dos enunciados. 
De acordo com essa definição, o foco durante a análise estrutural recai, sobretudo, sobre o conteúdo, ainda não sobre as estruturas linguísticas propriamente ditas. Contudo, essa análise já deve apontar para "a explicitação de enunciados e de suas recorrências". Nesse momento analítico, procurei também identificar o que chamei de subfeixes discursivos, por ter me dado conta, no andamento do processo, de que a delimitação em torno do parto e da assistência, enquanto feixe discursivo, equivalia a um recorte ainda demasiado amplo. Embora não haja essa categoria na vertente de ADC aqui adotada, Siegfried Jäger (2012, p.87) faz, em sua introdução, uma observação quanto à possível necessidade de subtematização, sem, contudo, reconhecer a necessidade de estabelecer essa possibilidade como algo fixo, pois a opção deveria ser pesada por cada pesquisador/a em conformidade com objeto de estudo escolhido e suas características. No meu caso, isso pareceu válido, especialmente porque esses subfeixes podem se configurar como novos feixes discursivos para análises posteriores. Na execução dessa etapa, utilizei de uma ferramenta para análise de dados qualitativos, o NVivo, para uma melhor e mais rápida organização dos dados analisados. ${ }^{17}$

A microanálise, também chamada análise fina, é o momento de tratar "tanto do conteúdo quanto da estrutura textual, abrangendo as estratégias de fala e a argumentação assim como os meios sintáticos de que as/os participantes discursivas/os se servem” (M. Jäger, 1996, p. 53). Importante é dizer que, em todos os passos analíticos, categorias analíticas são ferramentas úteis na escavação em busca dos enunciados. Tanto a ADC de Duisburg, quanto a escola anglo-saxã e seus desdobramentos latino-americanos, sugerem algumas categorias, que devem, contudo, ser entendidas como uma caixa de ferramentas aberta, da qual se pode pegar o que for necessário, assim como adicionar ferramentas que estejam faltando (S. Jäger, 2012, p. 8). Dessa maneira procedi, deixando-me guiar principalmente pelos fragmentos discursivos com os quais me deparava, e pelas categorias que eles "solicitavam”. Sobre essas categorias passo a escrever na próxima subseção.

2.4.2. Categorias analíticas na ADC da Escola de Duisburg e abordagens complementares.

Como escrevem Ramalho \& Resende (2011, p. 113), “a escolha de que categorias utilizar para a análise de um texto não pode ser feita a priori. É sempre uma consequência do próprio texto

17 Mais detalhes sobre as possibilidades de utilização da ferramenta no manual NVivo 10 for Windows. Getting started guide. Portuguese. 2014. Resende (2016, no prelo) também descreve de maneira bastante didática uma possibilidade de uso dessa ferramenta para pesquisas em ADC, buscando "lançar luz sobre o fazer analítico, que muitas vezes [...] pode parecer um passe de mágica, mas não é, de forma alguma. Análises não brotam dos dados; ao contrário, são resultado, como sabemos, de muitas horas de dedicação ao trabalho.” 
e das questões/preocupações de pesquisa". Portanto, as categorias apresentadas a seguir são as que atenderam a essa condição.

Interdiscurso, interdiscursividade e intergenericidade.

Uma das categorias analíticas utilizadas por Margarete Jäger (1996) é o interdiscurso, caracterizado pelo entrelaçamento de elementos de dois feixes discursivos distintos. Fairclough (1992, 2003) e Chouliaraki e Fairclough (1999) falam em interdiscursividade, entendida como uma interseccionalidade entre gêneros, discursos e estilos num mesmo texto, Resende, entretanto, prefere definir interdiscurso como "entrecruzamento de discursos, reservando a intergenericidade para o entrelaçamento entre gêneros". Cremos que essas propostas não são excludentes, pois é por meio da verificação de interdiscursividade num dado texto é que podemos deduzir e existência de um interdiscurso. Ademais a intergenericidade pode ou não ocorrer paralelamente ou independentemente da interdiscursividade.

Metáfora.

O simbolismo coletivo, proposto por Jürgen Link (Link, 1982; Link e Link-Heer, 1994, apud M. Jäger, no prelo) é adotado na abordagem de Margarete Jäger (1996). Segundo ela, a categoria corresponde ao conjunto de estereótipos culturais, cuja aplicação e reprodução também se dá coletivamente. Trata-se da "totalidade das alegorias, dos emblemas, comparações [...], pars pro toto, modelos e analogias ilustrativas de uma cultura" (S. Jäger e Zimmermann, 2010, p. 70 apud M. Jäger, no prelo). Esse simbolismo seria o responsável por permitir que determinadas lógicas sociais se reproduzam, em grande medida, devido a sua plasticidade, a seu teor imagético, que permite transportar sentidos de um campo para outro por analogia. Numa nota de rodapé, em Fatale Effekte, Margarte Jäger (1996, p. 30) escreve que essa categoria se aproxima muito do que outras/os autoras/es, como Lakoff e Johnson (2002, p. 45) chamaram metafórica, ao defender que "nosso sistema conceitual ordinário, em termos do qual não só pensamos mas também agimos, é fundamentalmente metafórico por natureza." À totalidade das metáforas, dos estereótipos culturais, das figuras de linguagem utilizadas cotidianamente para conceituar a experiência, Margarete Jäger (1996) chama simbolismo coletivo. Na pesquisa em pauta, utilizei apenas do aspecto metafórico desse simbolismo, preconizando a metáfora como categoria analítica, especialmente nos termos de Lakoff e Johnson (2002). 


\section{Avaliação.}

Além do aporte teórico da ADC, vertentes inglesa, alemã e latino-americana, também servi-me de algumas contribuições da Linguística Sistêmico-Funcional (LSF). Na LSF, a função primordial da linguagem é a comunicação: ao nos comunicarmos por meio das potencialidades da língua, participamos de acontecimentos discursivos, em que a interação social é mediada por textos. Ao lado de sua função interpessoal, de estabelecimento de relações sociais (Halliday, 2004; Martin \& White, 2005), a linguagem também é utilizada para representar o mundo (em discursos particulares, que compõem feixes discursivos específicos), para a construção discursiva de identidades ou identificação (em estilos particulares), para a ação discursiva no mundo (em gêneros particulares). Foi por meio dessa conceituação de discursos, estilos e gêneros como associados às funções da linguagem - ou aos significados - que Fairclough (2003) ampliou o diálogo teórico entre a LSF e a ADC (ver discussão mais detalhada em Ramalho \& Resende, 2006). Nessa ponte é que entendemos a categoria avaliação, conforme o aporte de Martin \& White (2005) e sua teoria da avaliatividade. Segundo essa proposta, a atitude é um dos sistemas de avaliação e se subdivide em três categorias analíticas: o afeto, o julgamento e a apreciação. $\mathrm{O}$ afeto diz respeito a recursos para a representação de reações emocionais a comportamentos, textos ou processos e fenômenos, registrando sentimentos positivos ou negativos. O julgamento se refere a recursos para avaliar comportamentos de acordo com princípios normativos, dividindo-se em dois subtipos, a estima social e a sanção social - a estima diz respeito à normalidade, capacidade, tenacidade de alguém, enquanto a sanção refere-se à sua veracidade ou propriedade na realização de suas tarefas e execução de suas atividades nas relações interpessoais. Por fim, a apreciação remete a recursos para a representação do valor das coisas e das pessoas também no que se refere a questões estéticas. Esses critérios foram utilizados nas análises, especialmente na microanálise da carta de Elena.

\section{Modalidade}

Fairclough (2003, p. 172) afirma que assertivas avaliativas, avaliações, dizem respeito ao que é bom ou ruim, ao que é desejável ou indesejável, e se relacionam intimamente com a a modalidade, categoria que retoma dentre as categorias analíticas discutidas por Halliday. Distingue modalidades epistêmicas, relacionadas ao grau de comprometimento com a verdade do que se afirma, e modalidades deônticas, relacionadas ao grau de obrigatoriedade ou necessidade do que se propõe. As modalidades se constroem como categóricas, tanto em termos de afirmação quanto de negação, quando as afirmativas ou negativas de apresentam em termos 
absolutos. Ou, ao contrário, utilizam marcadores explícitos de modalidade e ponderação (verbos modais, advérbios modais etc.). Ademais, as modalidades também explicitam o grau de subjetividade do comprometimento ou ocultam a subjetividade presente em qualquer declaração por meio de marcadores de objetividade. Segundo Fairclough (2001, p. 200 apud Resende \& Ramalho, 2006), deve-se observar se o "falante projeta seu ponto de vista como universal ou age como veículo para o ponto de vista de um outro indivíduo ou grupo".

\section{Pressuposição.}

A pressuposição, ou o pressuposto, corresponde a algo que, apesar de não dito explicitamente, é tomada como algo dado e aceito pelas/os participantes do discurso. De acordo com Margarete Jäger (1996, p. 61), considerar os pressupostos discursivos permite perceber nos fragmentos discursivos a afiliação de participantes do discurso também com aspectos discursivos não expressos abertamente, mas que se (re)produzem apesar disso na ação discursiva.

\section{Coesão.}

Quanto aos mecanismos coesivos que, ao passo em que costuram a tessitura textual, também realizam relações de significado entre partes do texto, Ramalho \& Resende (2011, p. 123) relembram que Halliday (2004):

Ao tratar as relações estabelecidas entre orações pelos mecanismos de coesão textual, [...] distingue três tipos de relações lógico-semânticas de expansão entre orações: elaboração, extensão e realce (Halliday, 2004). Temos elaboração quando a oração que expande o significado expresso em outra provê uma maior caracterização da informação dada: reafirma, esclarece, refina, exemplifica, comenta (expressões-chave aqui seriam 'isto é', 'ou seja', 'por exemplo'). Na extensão, uma oração expande o significado de outra introduzindo algo novo por meio de adição, deslocamento ou alternativa ('e', 'ou', 'mas'). No realce, uma oração destaca o significado de outra, monta-lhe um cenário qualificando-a como característica circunstancial em referência a tempo, espaço, modo, causa ou condição ('quando', 'se', 'para', 'porque', 'por causa de' etc.).

Considerar aspectos como a elaboração, a extensão e o realce pode ser útil para evidenciar estratégias retóricas e a produção de sentidos que talvez não seja tão evidente em uma leitura mais superficial. 
Intensificação.

Martin \& White (2005, p. 20) mencionam três tipos de realização prosódica que poderiam ser úteis na interpretação das maneiras como elementos avaliativos podem operar como um motivo cumulativo, e um deles seria a intensificação, um tipo de realização que se assemelha a aumentar o volume, de tal maneira haja uma reverberação da prosódia no co-texto, por exemplo, por meio da repetição, exclamação, uso de superlativos e qualificadores.

2.5. Base material e corpus analítico.

A base material para observação, análise e interpretação nesta tese, meu dossiê, por assim dizer, é bastante diversa e corresponde a:

(a) participação ativa desde há aproximadamente seis anos, período que inclui duas gestações, dois partos e pós-partos, inicialmente como beneficiária e posteriormente como ativista, no crescente movimento pela humanização do parto e do nascimento no Brasil, ou, mais propriamente, pela garantia dos direitos sexuais e reprodutivos das mulheres e dos direitos da/o recém-nascida/o;

(b) etnografia, presencial e virtual, em combinação com a ADC, nos termos defendidos por Hammersley (2005);

(c) relatos de parto redigidos por mulheres contando sobre sua experiência pessoal, coletados ou gerados especialmente para a pesquisa;

(d) entrevistas com mulheres e com algumas das poucas parteiras urbanas de Brasília;

(e) cartas redigidas e enviadas por mulheres a sua/seu obstetra, comentando os serviços de atenção que (não) lhes foram prestados durante o parto;

(f) postagens em blogs referentes ao parto e à maternidade;

(g) representações audiovisuais da gestação e do parto;

(h) artigos diversos publicados em veículos de comunicação da mídia tradicional.

Quanto a essa base material, devo ressaltar que diz respeito a toda a imersão destes últimos anos e que fundamenta sobretudo, mas não somente, a contextualização do problema social em questão, além de ter servido, mesmo quando não explicitamente mencionado, de subsídio tanto para a análise estrutural quanto para as análises finas. $\mathrm{O}$ primeiro item da base material mencionado, meu envolvimento direto no movimento pela humanização da assistência obstétrica, é também indicativo da posição discursiva de onde me reporto. 
$\mathrm{Na}$ interação com algumas das colaboradoras foram realizadas entrevistas temáticas abertas, nas quais o tema do parto e do nascimento foi apresentado como um tópico a ser comentado, deixando as delimitações e recortes temáticos a cargo da colaboradora. Conforme defende a historiadora Lucilia de Almeida Neves Delgado (2006, p. 22), entrevistas temáticas podem “constituir-se em desdobramento dos depoimentos de histórias de vida, ou compor um elenco específico vinculado a um projeto de pesquisa, a uma dissertação de mestrado ou tese de doutoramento". Recorri a uma historiadora, pois, nesse ponto, tem sido de extrema valia uma maior aproximação com a metodologia da história oral, tal como a apresentam Amado \& Ferreira (2001, p. xvi), isto é, como uma metodologia que estabelece e ordena procedimentos de trabalho com fontes orais.

Inicialmente, pretendia submeter também as entrevistas transcritas a uma análise fina; entretanto, tendo optado por uma análise densa, em que fragmentos discursivos representando, na voz das mulheres, o evento do próprio parto fossem considerados em sua íntegra, não seria possível, sem extrapolar os limites de extensão desta tese, incluir a voz de profissionais da assistência, especialmente se além de parteiras eu também procurasse inserir a voz de médicas/os, reservando-lhes o mesmo espaço e atenção analítica dedicada à voz das mulheres. Por esse motivo, decidi me ater, neste trabalho, somente à voz das mulheres, embora de maneira alguma desconsidere a necessidade de ampliar o estudo, analisando também a representação e a identificação discursiva na voz de profissionais, no futuro.

$\mathrm{Na}$ delimitação do corpus analítico, foi primeiro essencial a decisão de contemplar analiticamente a voz das mulheres representando o evento do(s) próprio(s) partos(s) em textos de teor autobiográfico. Embora essa representação apareça em outros gêneros discursivos, percebo tanto os relatos quanto as cartas a obstetras como especialmente representativos do feixe discursivo em questão, quando se tem como objetivo acessar a voz das mulheres, por isso a escolha por contemplar esses dois gêneros. Um relato, ou uma carta à/ao obstetra, é um texto monográfico de autoria da mulher, que o escreve por iniciativa própria e sendo a responsável pelos aspectos abordados, assim como por todas as decisões textuais necessárias. Numa entrevista concedida a um jornal, por exemplo, a fala da mulher passa necessariamente pelo crivo da entrevistadora, da editora e demais envolvidas no processo que culmina na publicação. Ademais, esses textos, especialmente os relatos, são na maioria das vezes divulgados, primeiramente, em círculo mais ou menos fechados, restrito a mulheres, permitindo a abordagem de temas afetos à intimidade que, provavelmente, não seriam tratados se o público imaginado fosse outro. Numa época, contudo, em que as redes sociais intensificam a interação 
de maneira sem precedentes, e na qual mesmo círculos restritos podem alcançar uma expansão que rapidamente converte o particular em público, também pode-se dizer que cada relato publicado constitui um antecedente, acional e temático, que faz com que cada vez mais mulheres decidam falar, cada vez mais pública e abertamente, sobre assuntos os quais teriam calado em outras épocas.

Enfim, dentre tantos relatos e cartas lidas, procurei selecionar de forma a garantir alguma representatividade às diferentes maneiras de parir/nascer e às avaliações possíveis, entre positivas e negativas, do evento vivido. Assim cheguei a 18 relatos de parto, selecionados dentre o arquivo pessoal que fui construindo desde o início da pesquisa. Quanto às cartas a obstetras, elas chegaram "com o bonde andando", com a sugestão de Elena, e não são tão abundantemente disponíveis ou acessíveis quanto os relatos, por isso utilizei todas as que coletei, que são apenas cinco. Todo esse material constituiu o corpus analítico para a análise estrutural.

Diante de um volume extenso de material textual nesse corpus analítico, para dar início à análise, submeti 18 relatos de parto e cinco cartas à/ao obstetra a uma análise temática, realizada com o auxílio de um software para a análise de dados qualitativos, o NVivo. Essa ferramenta me foi útil no escrutínio e na subtematização dos fragmentos discursivos, pois me possibilitou agrupar fragmentos de textos distintos de acordo com o tema identificado, a uma velocidade muito maior do que aquela que seria possível em uma análise sem o uso do software. Nesse momento, tinha as questões de pesquisa em mente, sem, entretanto, deixar de estar atenta para perceber as novidades que os textos me apresentariam. Dessa maneira, cheguei a uma lista de subfeixes, ou sub-agrupamentos temáticos referentes ao conteúdo dos relatos. No Capítulo 3, dedicado à análise estrutural, apresento os principais subfeixes evidenciados.

Em nova seleção, foram então escolhidos dois documentos de cada tipo para serem microanalisados. Os relatos foram escolhidos por critérios qualitativos: o primeiro, por abranger duas experiências, uma cesárea e um parto domiciliar; o segundo, por tratar de um subtema especialmente afeto à representação discursiva do parto: a questão do medo. No caso das cartas, a primeira selecionada e analisada foi a carta de Elena, análise feita antes mesmo da decisão de incluir outras cartas no trabalho; a segunda carta foi escolhida por ser a única elogiosa e a representar gratidão e satisfação pelo atendimento vivenciado, sem com isso deixar de ser bastante representativa, enquanto ato de resistência e denúncia, da violência obstétrica estrutural. As escolhas dos dados para microanálise, então, não atendem a critérios de 
representatividade em termos estatísticos, mas em termos qualitativos dirigidos à diversidade de situações que contemplam.

Antes de apresentar as colaboradoras de pesquisa e passar à análise estrutural, gostaria de falar sobre aspectos teóricos relacionados ao aspecto autobiográfico dos textos. Lejeune (2006 apud Pace, 2013, p. 1) define o "pacto autobiográfico" como "o engajamento de um autor em contar diretamente sua vida (ou uma parte, ou um aspecto de sua vida) num espírito de verdade" ou ainda "o relato retrospectivo em prosa que alguém faz de sua própria existência, quando coloca em destaque sua vida individual" (Lejeune, 1998, p. 10 apud Pace, 2013, p. 4). Conforme assevera Ana Amélia Pace (2013, p. 4), apesar das críticas, essa ainda seria a definição mais aceita para a caracterização de textos autobiográficos, por isso entendo que meu corpus analítico também possa ser qualificado como autobiográfico. Nas análises, apontarei aspectos pontuais ratificadores dessa denominação.

Baseando-se em Lejeune (1975), Hammerschmidt (2011) defende, em seu texto “"Ich' ist ein Roman", que "dizer tudo" seria o anseio da autobiografia tradicional, que se perceberia como um gênero referencial e, portanto, como gênero textual que refletiria uma imagem original, exterior e anterior ao texto em questão, por meio do qual o "eu" autobiográfico buscaria texturizar veridicamente sua experiência de vida, de forma que o texto fosse como um espelho de sua/seu autor/a. Aí estaria implicada igualmente a identidade entre autor/a, narrador/a e protagonista e um consequente "pacto biográfico" entre leitor/a e autor/a, baseado na veracidade da narrativa. Entretanto, os escritos autobiográficos resultariam de uma retrospectiva, cujo efeito seria um fendilhar, uma desintegração do "eu" autobiográfico entre aquele que narra e aquele que é narrado.

$O$ fato de o relato ser realizado sob uma perspectiva atualizada e, supostamente, melhor informada, reconhecendo o engano anterior, abriria a possibilidade de que a perspectiva atual pudesse estar igualmente equivocada. Além disso, no mesmo texto, é problematizada a limitação da memória humana, que tornaria qualquer projeto autobiográfico suspeito, pela inegável possibilidade de que o texto dele resultante equivalha antes a uma imagem fictícia, vislumbrada pelo "eu" atual com relação ao passado vivido, e não ao que de fato ocorreu. Mesmo caso considerássemos uma pessoa com uma capacidade superior ou infalível de recordação, qualquer relato seria baseado somente em uma seleção dentre todas as facetas da experiência vivida, organicamente caótica, organizada no texto de maneira linear e inevitavelmente redutora da complexidade original. Desta maneira, Hammerschmidt comenta 
como desde o surgimento do gênero textual autobiográfico, atribuído à publicação das Confissões de Agostinho (1980 [397 e 398], p. 209), ainda no século IV, sedimentado com a obra de mesmo nome, escrita por Rousseau, no século XVIII, até o século XX, teria se desenvolvido a consciência da impossibilidade de representação fiel e verdadeira de um "eu" em textos autobiográficos, fato que teria promovido uma mudança conceitual, da autobiografia para a autoficção, cujo efeito direto seria o reconhecimento da impossibilidade de se separar literatura referencial de literatura ficcional, escritos autobiográficos de escritos romanescos, pois em ambos sempre ocorreria um trabalho texturizador, constitutivo, com o significante, com a língua, que exigiria que além de autor/a, narrador/a e protagonista, como proposto por Lejeune (1975), considerássemos também o fator ficcional como inevitavelmente presente em quaisquer textos autobiográficos.

Dito isso, e considerando a cartas e relatos aqui analisados como textos autobiográficos, escritos, em sua maioria, após uma espécie de ‘conversão' e desde uma perspectiva mais bem informada, relatando um momento da trajetória de vida, nos vemos diante da pergunta sobre a validade de textos cujo teor ficcional seria constitutivo e, consequentemente, limitador da veracidade das narrativas. Diante desse aparente impasse, qual seja, a intenção de considerar textos autobiográficos, portanto, constitutivamente "ficcionais", como corpus analítico de uma pesquisa que se propõe minimizar um problema social concreto, real, me alinho a Margarete Jäger (1996, p. 38) quando afirma que, como analista do discurso, não estamos interessadas em descobrir se o que as pessoas dizem 'procede', antes nos interessa descobrir o que motivou as pessoas a dizer o que disseram, assim como quais seriam as consequências discursivas desses ditos.

Ainda com relação a textos autobiográficos, Pace (2013, p. 6) fala sobre a disposição, por parte da/o autobiógrafa/o, de transmitir as motivações para escrever, na busca de "um novo nascimento":

[d]a parte do autobiógrafo, conta menos a exposição dos fatos vividos do que a disposição em elaborar uma escrita que transmita ao leitor as suas motivações em escrever sobre si. Seu texto ultrapassa a esfera referencial, em direção a uma esfera própria da escrita, buscando ali um novo nascimento (...).

Essa afirmação, além de proporcionar um encontro entre a busca da analista de discurso, como definida por Margarete Jäger, é de certa forma metafórica e se adequa sobremaneira à qualidade 
dos textos por mim analisados, nos quais, diversas vezes, é mencionada a razão para a escrita, assim como a busca por um "renascer" após a violência sofrida, além da intenção de contribuir também para que outras mulheres tenham a possibilidade de viver "um novo nascimento", uma "nova" forma de parir e nascer, por exemplo, no trecho com o qual Elena conclui sua carta à obstetra:

Escrevi esta carta para tentar me limpar um pouco do que aconteceu há dois anos e meio atrás para me libertar para conseguir parir dessa vez. Naquela época eu tinha certeza que era capaz de parir. Você me tirou essa certeza, que estou tentando recuperar. Escrevo também para que você saiba das consequências do que fez para mim e provavelmente para outras mulheres também. Quem sabe você poderia até manter sua conduta, porém sendo mais honesta, avisando as pacientes das suas práticas, para aquelas que ainda não estão bem informadas possam ter a opção de tomar outro caminho a tempo.

A seguir, apresento sucintamente as colaboradoras de pesquisa, as autoras dos textos que compõem o corpus analítico. Ressalto que usarei pseudônimos para todas as autoras de relatos de parto e de cartas à/ao obstetra, independentemente de o texto analisado ser um documento público ou um dado gerado especificamente para este estudo, pois essa me pareceu a maneira mais simplificada e simétrica de lidar com todas as mulheres. Organizei a apresentação por ordem alfabética dos pseudônimos, primeiro das autoras de relatos de parto, ainda que também possam ter escrito uma carta, e em seguida, das autoras de cartas somente.

\subsection{Colaboradoras de pesquisa.}

Nesta apresentação das colaboradoras de pesquisa, autoras dos escritos componentes de meu corpus analítico, contrario, de certa forma, as expectativas com relação a regularidade e uniformidade dos dados biográficos apresentados, assim como também com relação à possível expectativa de uniformidade no tratamento dispensado a cada uma das autoras. No que diz respeito aos dados biográficos, apresento os que tenho, quase sempre com base no que a autora mesma decidiu incluir em seu texto, às vezes, trazendo informações a mais ou a menos, variando de acordo com o grau de intimidade ou de colaboração preexistente ou alcançado durante a pesquisa. Isso também se reflete, por vezes, no espaço dedicado a cada autora nesta apresentação. Mesmo ciente de que isso pudesse contrariar expectativas, optei por não forjar forçosamente uma uniformidade que não existia somente para corresponder a critérios acadêmicos dos quais não estou de fato convencida de que sejam realmente relevantes para a 
validade de meu estudo, no qual prefiro manter a rusticidade e a imperfeição produtivas em detrimento de um polimento ou uma perfeição estéreis.

\section{Amanda: "Acho muito difícil você conseguir ter parto normal."}

Amanda tinha 36 anos aos nove meses de gestação. Seu sonho, como ela mesma declarou, era vivenciar um parto normal, sendo atendida pela Dra. Ana Luiza, sua médica de confiança “desde muito antes de começar a sonhar em ser mãe”. Acontece que, às vésperas do nascimento de seu primeiro filho, Dra. Ana Luiza foi acometida por uma forte gripe, que a impossibilitaria de acompanhar o parto de Amanda. Portanto, a médica lhe recomendou que procurasse Dr. Ricardo, seu colega de consultório, para que Amanda não ficasse desamparada caso ela não melhorasse. Seguindo o conselho de sua obstetra, Amanda procurou Dr. Ricardo, que nesse primeiro contato já expressou seu receio de que Amanda não conseguisse parir ou sequer entrar em trabalho de parto devido a sua idade avançada para uma primigesta, ou seja, para uma mulher que está gestante pela primeira vez. Amanda se indignou diante de tal "avaliação" e, depois de outras conversas e da sugestão de agendamento de cirurgia, buscou outra opção: dirigiu-se ao plantão de um hospital quando entrou em trabalho de parto, já que Dra. Ana Luiza de fato não se recuperara a tempo. Lá foi atendida por um plantonista, que lhe rompeu a bolsa amniótica com um toque vaginal durante o exame clínico. A situação fez com que Amanda por fim resolvesse telefonar para Dr. Ricardo mesmo, pois, segundo ela, "não tinha muitas opções! Estava morrendo de dor, morrendo de medo, morrendo de ansiedade". Por fim, Amanda foi operada e deu à luz seu filho, Miguel. Já concluindo seu relato, escreveu: "No final das contas, foi muito legal. Retiradas as preocupações, apreensões e o stress que eu tive, o que importava era que aquele médico que eu odiava trouxe ao mundo o meu filhinho querido. [...] No final das contas.... Obrigada, Dr. Ricardo !"

Eu e Amanda nos encontrávamos em manhãs de domingo, quando, acordadas cedo por nossos espertos bebês, saíamos para tomar café da manhã pelas padarias da cidade, onde acabávamos encontrando outras famílias com bebês madrugadores e começávamos, inevitavelmente, a trocar impressões sobre o momento da vida em que nos encontrávamos, o exercício da maternidade, o evento do nascimento das crianças, e também sobre a via do nascimento. Foi falando sobre isso e sobre minha pesquisa, ainda bastante incipiente à época, que convidei Amanda a registrar por escrito a experiência compartilhada em nossas conversas, e ela aceitou prontamente. Recebi seu relato por e-mail em outubro de 2010, pouco mais de um ano depois do nascimento de Miguel. 


\section{Anita: "Por que parir em casa? Minha casa, meu lugar de poder."}

Anita compartilhou seu relato um mês e onze dias após o nascimento de sua primeira filha, quando, "inspirada por esse movimento da marcha do parto em casa e outros que vêm acontecendo por aî", resolveu compartilhar o relato de seu parto domiciliar, assistido por enfermeiras parteiras e uma doula, na lista de discussões para gestantes e paridas da qual também sou membro. Ela relatou ter tido a primeira consulta de pré-natal com a equipe de assistência dois dias antes de entrar em um "falso" trabalho de parto e que pariu oito dias depois num momento de nascimento que "foi lindo, profundo e transformador".

\section{Bertha: "A luta que pariu."}

Bertha, à época com 27 anos, teve seu relato publicado no blog de uma de suas doulas poucos dias após seu parto domiciliar em 2013. Ela pariu seu filho assistida por uma equipe composta por duas doulas e uma enfermeira obstétrica. E para realizar esse feito, após ter ficado desempregada logo no início da gestação e não contar com o apoio necessário do pai de seu filho, apelou para a solidariedade de outras mulheres e realizou uma campanha de financiamento colaborativo para conseguir os seis mil reais necessários para financiar o atendimento. Segundo ela, "com muita leitura, muita pesquisa, [descobriu] que quando uma mulher se empodera para ter o seu parto respeitado, é como se tomasse para si o poder sobre sua vida e sua história sexual", e ela "realmente precisava disso". Seu relato é um dos documentos públicos que coletei durante minha etnografia virtual.

\section{Elena: "Mas mais do que outro filho eu queria parir."}

Elena é uma de minhas principais colaboradoras, pois além de ter começado a contribuir com o projeto desde o início, por volta de 2011, ela teve uma influência determinante na composição de meu corpus analítico, por ter sido a primeira a me enviar, melhor até, a sugerir a inclusão de cartas à/ao obstetra em minha base material. Além do relato de seu parto domiciliar assistido por parteira, também analisei a carta que enviou à medica que a operou, quando do nascimento de sua primeira filha por meio de uma cesárea indesejada, e pude realizar com ela uma entrevista temática semi-estruturada sobre sua relação pessoal com a questão do parto. Ademais, no decorrer do trabalho, ela esteve presente em ocasiões em que apresentei recortes analíticos da pesquisa e me comunicou suas impressões após ouvir ou ler sobre o desenrolar do trabalho, contribuindo assim para a reflexividade em meu estudo. Também conversamos sobre o 
documentário “O Renascimento do Parto", e Elena redigiu, atendendo a meu pedido, uma nota com suas impressões sobre filme.

\section{Gabriela: "Ele nasceu lindo, cheio de mecônio e encheu meu coração de amor. Mas tinha um pedaço de mim que estava arrasado pela cesárea."}

O relato de parto de Gabriela, coletado de uma página de apoio à maternidade, é o relato de dois eventos: do nascimento de seu primeiro filho, por uma cesárea em 2006, e do de sua segunda filha, num parto domiciliar dois anos mais tarde, o que se costuma chamar VBAC (vaginal birth after cesarean) ou PNAC (parto normal após cesárea). Em seu texto, Gabriela apresenta os caminhos que a teriam levado até a cesárea, pela qual ela assume a responsabilidade. Ela escreve: “A cesárea que tive quando meu filho [...] nasceu foi o resultado de uma série de acontecimentos que compõem a minha história e de uma série de escolhas que eu fiz desde muito antes de engravidar." Entretanto, ela relata ter tido certeza de estar "sendo acompanhada por um obstetra $100 \%$ cesarista", maneira como são chamados médicos com altos índices de cesarianas, e ter por isso trocado de médico por volta do oitavo mês de gestação. Contudo, essa decisão não evitou que, estando no hospital em trabalho de parto, ela tenha sido submetida a uma cascata de intervenções que podem ter tido como consequência final a cesárea indesejada.

\section{Iêda: "Eu tive meu filho em um esquema conhecido por profissionais da área da saúde como o limbo do parto."}

Iêda teve seu relato publicado pela EBC em 2013, numa notícia intitulada "Leia o relato de uma mulher que sofreu violência durante o parto", compartilhado da Agência Pública, onde o mesmo texto trazia o título "Na hora de fazer não gritou". Além desses sítios, o relato foi divulgado em pelo menos outros vinte endereços, caminho pelo qual também chegou a meu arquivo. Iêda relata ter sido atendida por plantonistas sem nome, ter sido submetida a descolamento de membrana e a toque vaginal coletivo, realizado "por um médico e seus estudantes". Nesse contexto, ela resume sua sorte ao fato de a terem "esquecido no fim da sala", pois assim foi poupada de outras intervenções desnecessárias. Para concluir seu relato, ela escreve: "Faz exatamente nove anos que tudo isso aconteceu e hoje é ainda mais doloroso relembrar porque descobri que o que vivi não foi uma fatalidade, ou um pesadelo: eu, como uma a cada quatro mulheres brasileiras, fui vítima de violência obstétrica". 
Isabel: "Ainda tive de fazer um certo esforço para me entregar ao processo, ao invés de recuar e fechar as pernas."

Isabel foi minha companheira no grupo de gestantes, onde nos conhecemos e compartilhamos com outras mulheres as nossas histórias. Após seu parto vaginal hospitalar em 2011, Isabel divulgou seu relato num grupo virtual composto por integrantes do grupo de gestantes. Tendo lido o relato, pedi para incluí-lo em meu arquivo, e alguns dias mais tarde recebi seu consentimento e um pedido de prazo para revisar possíveis erros, até que após mais alguns dias recebi a versão revisada. Por ter engravidado aos 40 anos pela primeira vez, Isabel foi considerada "uma gestante idosa, ou senil", o que, como ela mesma ressalta, "costuma ser considerado por alguns médicos indicação para cesariana". Como a opinião do médico que a acompanhava não parecia ser diferente, Isabel foi mais uma das mulheres que resolveu buscar uma alternativa já após o sétimo mês de gestação. Embora tomar essa decisão não tenha sido fácil, Isabel escreveu: "Esta não é uma decisão fácil, e acho que não deve ser tomada levianamente, mas é uma alternativa legítima e às vezes é a única forma de ter o parto que se deseja".

Isadora: "Até aquele momento, parto pra mim não era uma coisa pra se pensar, e sim que simplesmente acontecia e que seu médico faria da forma que ele achasse melhor e que cesárea ou normal tanto fazia."

O parto de Isadora aconteceu no hospital, acompanhada por duas doulas e pelo obstetra de sua escolha, com quem estava satisfeita, pois ele "foi maravilhoso" e concordou com o plano de parto que ela havia preparado. Depois de assistir a uma palestra no início da gestação, ela decidiu que gostaria de ter um parto natural e procurou o médico de um hospital considerado bom, onde poderia parir num labor room. Durante o trabalho de parto, em meio às dores, Isadora solicitou analgesia, e depois anestesia, o que parece ter levado ao que chamamos de intervenção em cascata. Em suas palavras: "Optei pela anestesia, acabei levando de brinde uma episiotomia e o uso do fórceps além de ter que ficar na pior posição do mundo para parir (deitada) contrariando a lei da gravidade. Além disso é possível que a anestesia tenha feito com que a força que eu fazia não fosse suficiente, afinal $80 \%$ do meu corpo estava completamente morto. Enfim, a posição que ele tava fez com que as coisas acontecessem dessa forma." O relato foi escrito sete meses mais tarde, em maio de 2004, e publicado num site de apoio à maternidade. 


\section{Ivana: "Demorei a relatar o caso por ser algo que ainda me machuca."}

Ivana me escreveu seu relato atendendo ao convite que lancei no grupo virtual que frequentávamos à época. Tenho a impressão de que não fosse isso, provavelmente, ela não teria escrito o relato, que não foi tarefa fácil. Com relação a sua preparação para o parto, Ivana relata que fez cursos e conheceu pessoas que, como ela, queriam ter um parto "o mais natural possível". Idealmente, teria seu filho aparado por uma parteira, mas não conseguiu se organizar para isso com nenhuma das únicas duas parteiras de que tinha notícias em sua cidade. Ela conta ter evitado hospitais particulares, por escutar sobre suas elevadas taxas operatórias, e procurou enfim uma maternidade que lhe disseram "ser humanizada". Durante o trabalho de parto, recebia orientações telefônicas de uma parteira de sua confiança. Sobre o tempo na maternidade, menciona uma equipe de enfermagem acomodada, que não lhe deu muita assistência. Depois de três horas de espera, lhe aplicaram ocitocina sintética, romperam-lhe a bolsa, puseram-na numa maca e realizaram uma episiotomia. Após o nascimento, o bebê foi levado para os primeiros cuidados e ela ficou sozinha na maca esperando quem a cuidasse, por um bom tempo, sem saber do bebê.

\section{Janaína: "Passei os 9 meses me preparando para muitas coisas, mas, principalmente, para vencer um medo que até hoje não descobri direito de que era..."}

O relato de parto vaginal hospitalar de Janaína foi publicado num perfil público de rede social virtual chamado "Relatos de Parto" em 11 de agosto de 2014, embora o parto tenha acontecido ainda em 2008. Com mais de 40 semanas de gestação e seguindo a orientação da médica, Janaína foi internada para a indução antes da entrada em trabalho de parto, contando, além de homeopatia, com a ajuda de "uma fitinha que libera um tal hormônio 'progesterona', que estimula o útero a começar com as contrações". No hospital, foi acompanhada pelo companheiro, a obstetra e uma doula. Lembra da bola "de pilates" como uma das "principais aliadas" da noite e fala de como a banheira inflável acabou não sendo usada, porque "aquela banheira murcha naquele banheiro apertado cujo chuveiro só jorrava água pelando, foi o último lugar que quis ficar".

\section{Laura: "Meu filho nasceu de uma cesariana desnecessária."}


Laura é minha amiga, embora há bastante tempo não moremos mais na mesma cidade. O seu relato foi publicado por ela num comentário a uma postagem por mim compartilhada, divulgando o trailer do filme "O Renascimento do Parto", em maio de 2012. Laura começa seu relato lembrando que há tempos apoia e se informa sobre o parto natural, e que, entretanto, se submeteu a uma cesárea, por ser a única alternativa que encontrou para poder ser acompanhada por seu companheiro durante o nascimento. Seu plano de saúde só cobria um hospital para partos em sua cidade, e lá não aceitariam a presença de seu companheiro durante o processo. Laura escreve que "à época [...] achava que isso era uma coisa óbvia, que no nascimento de crianças o pai poderia acompanhar mesmo sendo um parto normal”. De fato, deveria ser, sabendo-se que ela teve seu primeiro filho em 2010 e que a publicação da chamada Lei do Acompanhante data de 2005.

\section{Lívia: “Quando nos descobrimos grávidos, cada um sentiu um frio na barriga diferente".}

Na página onde o relato de Lívia foi publicado no final de 2013, é feita uma introdução ao relato em que aparece também uma fala do seu companheiro: "Para nós o parto não foi só da mulher, foi da família, meu também". E essa impressão também aparece em seu relato, que traz a história de uma gestante que, sempre acompanhada muito de perto por seu companheiro, a certa altura da gestação opta por trocar a médica que já acompanhava a família havia bastante tempo por uma equipe de assistência composta por uma "médica parteira", um "médico parteiro", e uma obstetriz. Seu parto natural aconteceu em um ambiente hospitalar. Além do relato, Lívia também enviou uma carta à sua obstetra, documento também integrante da base material da pesquisa e analisado em ambas as etapas analíticas, na análise estrutural e na microanálise dedicada às cartas.

\section{Norma: "Na minha primeira consulta com meu GO já cheguei causando, dizendo que ia pra faca, e que nem a pau o meu filho sairia por onde entrou."}

O relato de Maria foi publicado no início de 2012 num blog de autoria coletiva sobre questões da maternidade. Nele, ela conta que inicialmente queria se submeter a uma cesariana e que não contou com cumplicidade do médico que a atendia, que a orientou para se informar melhor. Seguindo seu conselho, ela afirma ter se tornado uma "xiita do parto natural". Surpreendentemente, o mesmo médico lhe sugeriu agendar a cesárea quando ela estava com 36 semanas de gestação. Esse motivo fez com ela também saísse atrás de alternativas, "médicos, encaixes, doulas, parteiras”. Enfim conseguiu um encaixe com médico favorável ao parto 
natural, entretanto teve pré-eclâmpsia e precisou marcar uma cirurgia emergencial. Maria afirma ter sido "crucificada" por suas "amigas xiitas" por não se opor à cirurgia, pois podia estar sendo enganada. Mas foi operada e sofreu com isso por um tempo. Depois, teria aprendido a respeitar e apoiar "todo e qualquer tipo de parto".

Olga: "A realidade dos atendimentos nos serviços de saúde não é animadora de um modo geral, e o quadro piora quando se trata de atendimento a mulheres negras."

Olga, uma mulher negra ativista, publicou seu relato em 2013 num blog destinado a discutir questões raciais. Em seu relato, ela comenta, sobretudo, momentos do acompanhamento prénatal e a invisibilidade sentida. Segundo ela, no início da gestação, em 2011, o assunto da humanização era para ela uma grande novidade, embora ela já soubesse que gostaria de ter um parto normal. Em seu texto, ela afirma que àquela altura mal sabia da luta que teria pela frente, num contexto em que a realidade é ainda pior para as mulheres negras, maiores candidatas à mortalidade materna. Ela reporta maus tratos na assistência pré-natal e também no início do trabalho de parto. Seu parto, apesar de normal, não foi como ela gostaria que tivesse sido.

\section{Rosa: "Passada a dor, tivemos uma cesárea super tranquila, respeitosa, com uma equipe que conversou apenas sobre a cirurgia e me apoiou o tempo todo."}

O Relato de Rosa foi publicado em seu blog pessoal no final de 2013, alguns meses após o nascimento de sua terceira filha. No evento, foi assistida por uma equipe de parteiras e doula, e vivenciou o trabalho de parto em seu lar, ao lado de seu companheiro. Entretanto, após horas de trabalho de parto sem dilatação, Rosa ouviu de sua parteira que teriam de "buscar sua filha na maternidade". Seguiu então entristecida e frustrada para a instituição, tendo de se despedir, pelo menos momentaneamente, do sonho do parto domiciliar. Contudo, seu relato ressalta o respeito e a tranquilidade da cesárea, garantidos por uma equipe focada em seu bem-estar.

\section{Tânia: "Busquei um G.O. que fizesse parto normal e acreditei."}

Tânia teve seu relato de parto publicado na página de sua doula em 2013. Cerca de seis anos após sua primeira gestação, que culminou em uma cesariana, Tânia escreveu sobre o parto domiciliar que trouxe ao mundo sua segunda criança, num VBAC. O relato do primeiro nascimento também integra meu corpus analítico, e é bem mais sucinto que o segundo relato, o que sugere uma mudança de perspectiva e uma escrita imbuída de um projeto na luta pelo parto respeitoso. Esse segundo relato foi um dos selecionados para ser submetido à lupa da 
microanálise, sobretudo por mostrar essa evolução de um parto para o outro também linguisticamente.

Com a apresentação de Tânia, concluímos a apresentação das autoras de relatos de parto e passamos às autoras de cartas ao obstetra.

\section{Aída: "Depois disso virei uma ativista ferrenha contra as cesarianas enganadas."}

A carta de Aída a seu obstetra foi escrita em 2012, quinze anos após a cirurgia a que foi submetida no nascimento de sua primeira filha. O médico que acompanhou, e operou, Aída, já a atendia havia 14 anos, como ela ressalta, desde a sua adolescência, e, durante toda a gestação, ouviu dela que queria um parto normal. Entretanto, no início do trabalho de parto, afirmou que ela teria um "problema de colo duro, grosso e posterior", o que tornaria necessária uma cesárea imediata, para evitar um trabalho de parto longo e arriscado para o bebê. Na carta, conta como transformou sua história de vida em engajamento pelo "direito das mulheres não serem operadas sem necessidade", e agradece ao médico por ter contribuído para isso. O texto é um documento que foi amplamente divulgado e o alcance da atuação de Aída no movimento pela humanização da atenção obstétrica é inquestionável.

\section{Dandara: "Só tenho realmente a agradecer Dr. Francisco, pois não precisei sair correndo."}

Dandara divulgou sua carta ao obstetra em seu blog pessoal em 2014, onde se apresenta como mãe em dedicação exclusiva a seus três filhos, de 10, três e um ano, o primeiro nascido, segundo ela, de um "parto normal hospitalar Frank ${ }^{18 ", ~ o ~ s e g u n d o ~ d e ~ u m ~ p a r t o ~ h o s p i t a l a r ~ h u m a n i z a d o ~}$ sem nenhuma intervenção, e o terceiro nascido de parto domiciliar. Na carta, ela fala de sua dificuldade em procurar um médico obstetra, devido à imagem negativa que teria do sistema de assistência obstétrica como ele se apresenta. Enfim, teria feito isso somente para não contrariar as expectativas de familiares, mas foi para o hospital disposta a "sair correndo" caso se visse ameaçada de uma cesariana desnecessária. Entretanto, sua experiência foi positiva, e a carta foi escrita a título de agradecimento pelo fato de o médico ter acompanhado o pré-natal e o parto

\footnotetext{
${ }^{18}$ Denominação recorrente no movimento, em alusão ao romance de Mary Shelley, no qual um monstro construído em laboratório pelo estudante de ciências naturais, Victor Frankenstein. Um parto corresponderia àquele parto que apesar de vaginal não poderia ser chamado normal, pelo fato de acontecer em meio a intervenções desnecessárias e a outras formas de violência, física ou psicológica.
} 
de seu segundo filho de maneira respeitosa, "com respeito à fisiologia, ética profissional e, principalmente, com humanização.”

Nara: "Eu sou uma dessas centenas, cheguei ao seu consultório em meados de novembro de 2009, grávida pelas 20 semanas."

Nara escreveu sua carta ao obstetra que conheceu quando estava na vigésima semana de gestação de seu primeiro filho, e logo no início da carta se dispõe a refrescar a memória do médico, que provavelmente não se lembraria de sua história, uma entre outras centenas de casos similares, entre as tantas pacientes de seu médico. Nara, que escreve a carta depois de ter parido seu segundo filho num parto natural, conta que chegou ao médico por indicação, depois de muitas outras consultas com obstetras distintos e uma perda gestacional bastante doída, com medo e fragilidade. A autora menciona a cordialidade nos atendimentos pré-natal, sem contudo deixar de citar sinais, por ela ignorados, mas posteriormente percebidos, das práticas do hospital onde mais tarde seu filho nasceria, "práticas duvidosas quando se trata de respeito aos direitos das pacientes e seus filhos". O filho de Nara veio ao mundo por meio de uma cesariana. Em sua carta, publicada num blog pessoal no início de 2013, ela diz escrever para dividir com o médico essa responsabilidade: ter "um filho que foi nascido pela tua urgência em [...] operar e outro que foi absolutamente respeitado".

Com Nara, concluo essa apresentação das colaboradoras de pesquisa autoras de relatos e/ou cartas às/aos obstetras submetidos à análise estrutural, que apresento no Capítulo 3, a seguir. 



\section{CAPÍTULO 3 Análise estrutural.}

Eu acho um desserviço a glamourização/romantização/ idealização/orgasmização do parto. Eu acho que seria uma beleza se nosso trabalho fosse de simplificar e contar a verdade sobre o parto. E não de vender um peixe que não podemos entregar. Não haverá harpas tocando, luzes multicoloridas emanando dos céus, perfume de rosas, rios de leite e dúzias de doulas virgens a abanar e entoar cânticos. É intenso, é corporal, é animal, pode ter sangue, suor, lágrimas, cocô, medo, força, gritos. E mesmo assim pode ser incrível. E lindo. E eu acho que pode ser incrível e lindo POR ISSO e não APESAR DISSO.

(Maíra Libertad Soligo-Takemoto)

Margarete Jäger (no prelo), escreve que a análise estrutural “atentará sobretudo para o conteúdo do material". Segundo ela, essa análise "aponta para a determinação de enunciados e de suas recorrências", sendo que dela podem resultar "textos particularmente típicos do discurso em questão", que deverão/poderão ser submetidos a "uma análise fina, com a qual se investigará a estrutura profunda dos enunciados". E essa análise estrutural deve acontecer após a contextualização, baseada em toda a base material e que permite delimitar o feixe discursivo em foco. Para realizá-la trabalhei com um corpus analítico composto de 18 relatos de parto e 5 cartas ao obstetra. Os subfeixes daí resultantes são apresentados a seguir.

Como já mencionei anteriormente, na execução da análise estrutural, tive sempre minhas questões de pesquisa como guia, entretanto não deixei de estar pronta a tentar perceber aspectos temáticos não previstos de antemão. Passo então, agora, a comentar os principais subfeixes identificados durante a análise estrutural. Importante é recordar que, neste capítulo, não se trata de empreender uma análise fina. Aqui, os fragmentos são organizados de forma a ilustrar percepções resultantes da macroanálise, mas não se prestam a uma análise textualmente orientada em profundidade. O objetivo será, então, mapear os temas mais recorrentes nos documentos do corpus.

\subsection{Autoidentificação.}

Como era de se esperar, tratando-se de textos autobiográficos, tematizando um evento relacionado tão intimamente às autoras, há muita autoidentificação nos relatos e cartas. Utilizome do termo identificação para nomear e enfatizar o aspecto processual dessa ação de identificar(-se), apoiando-me, como já dito, em Fairclough (2003) e Hall (2007). 
A autoidentificação é, na realidade, como um recorte transversal que perpassa todos os demais subfeixes apresentados a seguir. Nesta seção apresento então, exemplarmente, alguns eventos e faço algumas considerações, que de maneira alguma podem ser considerados exaustivos e que, na realidade, são apenas a introdução do que será concluído pelos subfeixes subsequentes e, ainda, após a etapa microanalítica.

As autoras, muitas vezes, se identificam como inocentes ou ingênuas no momento em que confiaram em suas/seus obstetras, como o faz Aida em sua carta, na qual relata a violência de ter sido submetida a uma cesárea desnecessária:

(1) Eu, do alto da minha inocência, e crendo que você jamais diria algo para me enganar apenas para facilitar seu feriado de Corpus Christi, aquiesci. Eu não queria, de fato, provocar dano à minha filha. Uma hora depois você se despedia de mim e ia atender o dia cheio do consultório.

Muitas delas também se identificam pelo relato da perda da confiança no potencial do próprio corpo com relação ao parir, além da fragilidade, logo após a violência sofrida, como Aida escreve também em sua carta:

(2) Passei quinze dias mal conseguindo me segurar em pé, tendo que dar de mamar a uma criança que eu nem conseguia segurar, por causa das dores. Porém passei dois anos acreditando que eu tinha um "problema de colo duro, grosso e posterior".

Essa falta de confiança, ou a fragilidade e também o medo, por vezes, já acompanha as mulheres antes mesmo do contato com a/o médica/o, devido a experiências anteriores, podendo ser intensificada ou diminuída a partir desse contato. Nara se descreve assim, no que se refere ao período pré-natal tratado em sua carta:

(3) Vinha de outras tantas consultas com diferentes obstetras e de uma sequência de sangramentos e repousos que levaram consigo um dos bebês que eu esperava, uma perda doída e que deixaria outras sequelas além do próprio luto por aquela alminha que não vingou na terra: à partir daquilo eu tinha duas características - aparentemente inerentes à maioria das grávidas, eu vim saber depois, mas em intensidades diferentes - medo e fragilidade.

$[\ldots]$

... aquele medo e aquela fragilidade me fizeram calar e seguir sendo sua paciente.

Recorrente também é a percepção que as mulheres tinham de serem apenas mais um número. Sobre isso, Iêda relata: 
(4) Durante o pré-natal, fui atendida por plantonistas sem nome. Também não me lembro do rosto de nenhum deles. O meu nome variava conforme o número escrito no papel de senha da fila de espera: um dia eu era 234, outro 525. Até que, durante um desses "atendimentos" a médica resolveu fazer um descolamento de membrana, através de um exame doloroso de toque, para acelerar meu parto, porque minha barriga "já estava muito grande". Saí do consultório com muita dor e na mesma noite, em casa, minha bolsa rompeu. Fui para o tal hospital do convênio já em trabalho de parto.

Outros aspectos da autoidentificação serão, como dito, mencionados a seguir, na apresentação dos subfeixes resultantes desta análise estrutural. Assim como as avaliações e a alteridentificação, que também são realizadas por meio de diversas estratégias.

\subsection{Espiritualidade e misticismo.}

Ressalte-se que todos esses fragmentos podem ter recebido mais de uma etiqueta; por exemplo, um fragmento em autoidentificação pode ser também relacionado ao aspecto místico ou espiritual do parto, como quando Anita escreve sobre a força do feminino sagrado, em (5):

Passei uma semana intensa, profunda, tratando de feridas muito antigas e mergulhando na minha própria sombra. Mas isso foi fundamental pro meu processo de preparo, para, finalmente, parir, em casa, com a força que o Feminino Sagrado me deu e, finalmente, tornar-me mãe.

Esse aspecto místico ou espiritual foi, depois dos agrupamentos menos específicos, como autoidentificação, avaliação e alteridentificação, o primeiro mais mencionado, com 13 ocorrências distribuídas por sete dos 23 textos.

\subsection{Violência.}

Número da sorte e do sagrado, para algumas pessoas, ou do azar, para outras pessoas, também foram 13 as menções, por mim consideradas explícitas, sobre violência obstétrica, curiosamente, também presentes em sete dos textos. Um exemplo desse tipo de fragmento foi escrito por Iêda, relatando seu constrangimento quando sofreu um exame de toque coletivo ou quando foi levada a uma sala com várias mulheres em trabalho de parto, no fragmento em (6):

(6) Antes de ser finalmente internada, passei por um exame de toque coletivo, feito por um médico e seus estudantes, para verificar minha dilatação. "Já dá para ver o cabelo do bebê, quer ver pai?" mostrava o médico para seus alunos e para o pai do meu filho. Consigo me lembrar de poucas situações em que fiquei tão constrangida na vida. Cerca de uma hora depois, me colocaram em 
uma sala com várias mulheres. Quando uma gritava, a enfermeira dizia: "pare de gritar, você está incomodando as outras mães, não faça escândalo”.

\subsection{Uma mão para segurar.}

Também se configura violência obstétrica (além de ser ilegal, por contrariar a Lei 11.108, de 7 de abril de 2005, que altera a Lei 8.080, de 1990, para garantir às parturientes o direito à presença de acompanhante durante o trabalho de parto, parto e pós-parto imediato) o impedimento de que a mulher tenha um/a acompanhante de sua escolha, fato que apesar do amparo legal é relatado por muitas mulheres. $\mathrm{O}$ direito ao acompanhante parece atender uma das necessidades mais recorrentes nos relatos lidos, durante todo o período da minha pesquisa, e também neste corpus analítico específico. Afirmo isso porque o terceiro tema mais recorrente entre os relatos e cartas foi a necessidade, para a mulher em trabalho de parto, de ter uma mão à disposição, a mão de alguém para segurar. Janaína escreveu, por exemplo:

Foi importantíssimo esse momento com o Enzo. Ele acabou sendo meu principal parteiro. Também foi importante ter quem segurar a mão. Precisava segurar a mão de alguém o tempo todo. Senti vontade de morder, apertar, gritar,... sentia que a hora estava chegando. Me sentia exausta e aterrorizada.

Também sobre essa necessidade Tânia escreveu, em (8):

Tive lapsos de consciência, mas as contrações me puxavam de volta. E eu tinha que segurar nas mãos de alguém. Nem lembro quais mãos eu peguei, mas tinha que segurar em alguém.

\subsection{Atendimento de rotina e "médico convencional".}

Seguindo com outros aspectos que apareceram nos textos, foram 10 as ocorrências em que as autoras mencionavam o que esperavam do atendimento de rotina, sobre o que aconteceria caso elas não tentassem arrumar alternativas a essa rotina. Nesse nó, que chamei "expectativas quanto ao atendimento de rotina" e que não era algo sobre o qual havia pensado diretamente no início da análise, agrupei comentários como este, de Dandara, no fragmento em (9):

(9) Confesso que não foi fácil tomar uma decisão e entrar em seu consultório, mesmo com indicações.

Não tenho bons sentimentos em relação à classe médica. Sei da raridade de um médico que cuida e acompanha um processo natural, como o parto, e instintivo, como cuidar da cria.

Quando pensava em médico obstetra pensava, primeiro, no terrorismo do parto normal que levaria nossos filhos a terem seqüelas permanentes (isso se 
saíssem vivos!) se não fosse a salvadora cesariana. Pensava nas inúmeras desculpas esfarrapadas que poderiam usar para me impedir de parir... Por outro lado, caso passasse na triagem e me permitissem parir, pensava na deturpação do parto: tricotomia, enema, bolsa estourada com agulha de crochê, anestesia, episiotomia, litotomia, kresteller, estribos e, finalmente, fórceps. Fora os incômodos toques do pré-natal.

Vê-se que a imagem de Dandara, enquanto esperava seu segundo filho, nascido em um parto hospitalar sem intervenções, engloba o medo da cesariana desnecessária, mas também, e sobretudo, a violência pela qual passariam as mulheres a quem fosse permitido parir. Note-se que Dandara mesma diz, sobre seu primeiro parto, ter sido um "parto Frank”. Suas expectativas, pode-se dizer, eram na realidade memórias de experiências vividas.

Amanda também menciona, no fragmento em (10), sua expectativa sobre o que considera um médico convencional e sobre a raridade dos "médicos 'pró-parto normal"”, especialmente em instituições particulares:

Acho assim : - Beleza. Se você não quer ter parto normal é um direito seu. Mas é você quem escolhe. Não o seu médico. Se você procura um médico convencional, ele provavelmente vai ser do tipo que gosta de cesárea. Mas é claro! - Cesárea é muito mais simples, rápida, tranquila, e lucrativa. Primigestas costumam ficar doze horas em trabalho de parto. - Já pensou na canseira que deve ser pra o médico?

Hoje em dia, se você quer ter um parto normal, você tem que procurar um dos raríssimos médicos "pró-parto normal”, ou se dirigir a um Hospital público.

3.6. Pluralidade da dor.

O próximo tópico a ser explicitamente mencionado, com uma das frequências mais elevadas, é a questão da dor. Essa dor é representada sob vários matizes. Fala-se da dor que faz perder a noção do tempo e gritar por anestesia; dores que exigem concentração e determinação; de “muuuuuuita dor", assim, com muitos us; fala-se de não lutar contra a dor e da capacidade de superação da dor, como atitudes necessárias à mulher que pare; dor que seria, na realidade, um medo do desconhecido; dor que causaria euforia, expressa pela metáfora do carrinho de montanha russa. Também se mencionam dores menos "naturais", dores resultantes de intervenções, como o toque; dor que, associada ao medo e à ansiedade, em situação de desamparo, faz optar pela cesárea; dor da cesárea, na cicatriz da cesárea; "dor fresquinha" da cesárea, mesmo anos após a cirurgia; dor causada pelo medo, diante do abandono. Entretanto também aparecem aspectos positivos associados à dor, como o fato de trazer felicidade certamente pelo prenúncio do nascimento que se aproxima; dor sentida durante um dos 
momentos mais lindos do trabalho de parto, sem impedir a beleza do momento; e a dor que ajuda a afrouxar os laços com a realidade objetiva e a estabelecer conexão com as emoções.

Em seu relato Janaína escreveu, em (11):

Aguentar as dores exigia concentração e determinação absurdas. Eu tendia a me contrair durante elas e isto as tornavam piores. Não conseguia olhar ninguém nos olhos, a não ser o Cris que fazia de tudo para me convencer que quanto mais eu relaxasse, mais fácil seria. Realmente quando eu relaxava durante uma contração, ela passava bem mais rápida e era mais leve. Mas não é tão simples assim, chega uma hora em que você já está totalmente desesperada e cansada.

Em outra representação de dor, o relato de Rosa sugere que, embora dor seja parte do parto, não precisa significar que o momento se torne um momento de horror; que todo o contexto e a companhia sempre tem influência no bem-estar geral da mulher, apesar de qualquer dor, no fragmento em (12):

E foi com 'Debaixo d'água', na voz da Maria Bethânia, que tivemos o momento mais lindo de todo o TP, somente Ari, eu e nossa pequena, e em meio a tantas contrações eu só conseguia pedir para que tivesse evoluído - pelo menos $3 \mathrm{~cm}$, eu pedia, pelo menos $3 . .$. a dor vinha cada vez mais intensa e nós três vivendo nosso tempo e momento.

Anita também situa, no co-texto, elementos positivos da dor que, apesar da intensidade, não a deixam assumir o primeiro plano no contexto narrado. Alguém lhe mostrando a cabecinha da filha no momento do expulsivo, o sorriso no rosto do acompanhante, tudo isso disputa a atenção e a sensação de Anita, que não está abandonada à própria dor, nem submetida a algo que a intensifique. Em suas palavras, em (13):

O momento do nascimento foi lindo, profundo e transformador. Depois de vencer esse colo, fiquei mais confiante, ainda tinha muita dor, mas era diferente! Vi a cabecinha da minha filha pelo espelho e o sorriso lindo do pai que esperava para recebê-la em suas mãos! Está chegando!

Sobre o papel da dor na conexão com o emocional e no afrouxamento dos laços com a realidade objetiva, Bertha escreveu, em (14):

Mas definitivamente a questão era muito mais profunda do que aquilo e eu precisava me aprofundar na minha inconsciência, afrouxar os laços com a realidade objetiva, estreitar a conexão com minhas emoções. A dor ajuda a gente com isso. Não tenho dúvidas de que é essa a função da dor em um trabalho de parto: a entrega total ao corpo, que tudo sabe. A dor me fez 
esquecer a vergonha. Me entreguei ao blackout do meu lado racional, passei a vocalizar alto e longo a cada contração.

Tânia mencionou a dor da cesárea, em mais de um fragmento do seu relato sobre o parto domiciliar que pôde viver depois, mas também se referindo ao tempo de espera, durante a segunda gestação, após uma cesárea, no fragmento em (15):

(15) E eu tentando não ficar ansiosa, via vídeos de partos lindos, pensava na minha cesárea, na ansiedade do parto da Gaia... e sentia ainda fresquinha a dor da cesárea. E sabia, que essa cicatriz só pararia de doer na próxima etapa: o parto.

E como último exemplo de fragmento relacionado à dor, reproduzo a seguir, em (12), uma passagem na qual Tânia menciona a dor sentida durante o parto domiciliar, como uma sensação cuja consequência é o sentimento de alegria, que relata ciente de que essa declaração pode ser associada a insanidade mental. Declaração que, eu diria, dada a consciência acerca de sua estranheza, pode ter sido estrategicamente selecionada para o relato como artifício de denormalização da negatividade atribuída à dor fisiológica característica da maioria dos partos. Sobre a felicidade trazida por essas dores, Tania escreveu:

(16) Ah, e o melhor estava por vir, em uma ou duas horas, meu TP ativo começou! Eu comecei a sentir as tais contrações doloridas e pulamos todas de felicidade quando começou! Sim! Parece loucura, mas eu estava muito feliz com minhas dores. Era como se, durante esse tempo todo eu estivesse na fila para "aquela" montanha russa incrível, e agora, com as contrações e dores, eu tivesse acabado de embarcar no carrinho. Estava eufórica. Aliás, todas nós estávamos.

Sem intenção alguma de romantizar ou defender uma suposta "obrigação" de a mulher sentir ou aceitar a dor, concordo com Guerci \& Consigliere (1999, p. 58), quando escrevem, em seu estudo "Por uma antropologia da dor", que

[u]ma antropologia da dor é hoje mais necessária que nunca. A indústria biomédica - acenando com uma espécie de utopia anestésica - contribui a aprofundar o silêncio secular que a cultura ocidental reservou à dor, fazendoa mais que nunca impensável e insuportável. Um exame transcultural revela percepções da dor não contidas no par cartesiano físico / espiritual e dependentes de uma variedade de fatores genéticos, ambientais e culturais. A dor é cultural ao menos na mesma medida em que é natureza, e assim é suscetível de uma diversidade de respostas não limitadas à quimioterapia.

Se aceitamos essa observação e concordamos que a dor seja cultural e discursiva e "suscetível a uma diversidade de respostas", interessa observar que outras possibilidades de lida com essa dor são aventadas nos relatos analisados, possibilidade para além da cesárea eletiva e prematura 
ou da anestesia química em trabalhos de parto normal hospitalar. Guerci \& Consigliere (1999, p. 61) asseveram que "por longo tempo as categorias fundamentais da dor não foram as mesmas em uso hoje". Com relação especificamente à dor e seu aprendizado, Guerci \& Consigliere (1999, p. 65) escrevem que:

História, fisiologia, imaginário, língua, posição social, valores dominantes e tantas outras coisas, tudo isso age contemporânea e historicamente sobre os indivíduos, plasmando sua percepção da dor e sua resposta a ela, modificando o modo que encara a sua definição, a sua importância e a sua suportabilidade. A dor, como outros acasos humanos, também se aprende.

Como a dor é tema recorrente no feixe discursivo referente ao parto, essa reflexão sobre a antropologia da dor, pareceu-me um suporte analítico útil e necessário.

\subsection{Convite à resistência.}

E, deixando a euforia da dor fisiológica presente em um parto natural, vamos a outro fator bastante presente nos textos analisados, a interpelação a outras mulheres, possíveis candidatas ao parto. Parece-me que uma característica comum a todos esses textos é o fato de terem certo teor de manifesto, de uma conclamação, de um convite à resistência, de uma defesa da utopia que parece ser um parto sem violência e com acolhimento. Embora essa característica seja subliminar na maior parte dos textos, em alguns fragmentos ela é bastante explícita e textualmente marcada, como nos exemplos de Nara, Isadora e Tânia, reproduzidos a seguir em (17), (18) e (19):

Que todas aquelas que se sentiram violentadas em seus direitos no momento do parto, pré ou pós manifestem-se por um futuro mais promissor para parturientes e suas crias. (Nara, carta ao obstetra)

(18) Nós mulheres precisamos começar a acreditar mais na nossa capacidade de parir sozinhas sem intervenções médicas, afinal a natureza é Divina. [...] Acreditem em vcs, meninas. (Isadora, relato de parto)

(19) Algo que desejei muito, tanto pelas minhas razões pessoais, quanto por todas as outras mulheres que, assim como eu, passaram por cesáreas desnecessárias ou qualquer violência obstétrica, para mostrar que sim, podemos mudar essa realidade, que podemos confiar em nossos corpos, que somos forte e sagradas, 
que temos o DIREITO de parir e de sentir toda essa luz. Que podemos mais. Sempre.

Busquem a verdade. Lutem pelos seus diretos. Vivam seus sonhos. Vamos mudar juntas o nascimento de um novo mundo. (Tânia, relato de parto)

\subsection{Ironia e metáforas.}

Antecipando um pouco a discussão sobre estratégicas linguísticas propriamente ditas, ainda grosso modo e não da maneira mais aprofundada como se dará na fase da microanálise, chama a atenção o recurso da ironia e da metáfora presente em muitos dos textos. A carta de Lívia a sua obstetra, escrita a mão e com direito a ilustrações é, quiçá, o exemplo mais evidente do uso da ironia como recurso retórico. A seguir alguns excertos em (20):

(20) A sra. me acompanha desde meus 12 anos. O tempo passou. Eu casei, engravidei e pari. Sim eu PARI!!!

A sra. acredita que pari numa banqueta de parto?!

*vou desenhar*

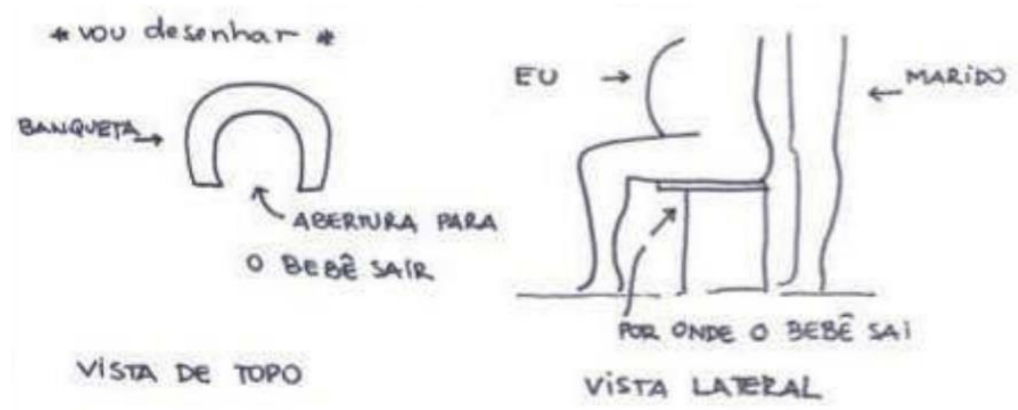

$[\ldots]$

Quando perguntei se poderia contratar uma doula a sra. perguntou o que era isso e eu devo ter explicado corretamente, pois a sra. disse que não precisava, que eu seria orientada pela sra.

* vou desenhar*

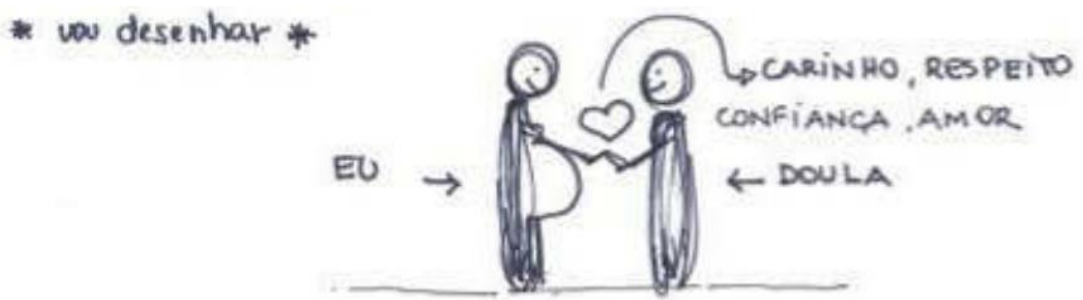

No que diz respeito às metáforas, foram utilizadas metáforas de cunho militar, metáforas associadas à condição animal, à mecanização, à crucificação e a brinquedos de um parque de diversão. Considero importante atentar para essas metáforas por concordar com Lakoff \& 
Johnson (2002, p. 45), quando eles defendem que "nosso sistema conceptual ordinário, em termos do qual não só pensamos mas também agimos, é fundamentalmente metafórico por natureza." Segundo esses autores, as metáforas não seriam estratégias decorativas ou poéticas, mas sim reflexo do sistema conceitual por meio do qual apreendemos o mundo. Em suas palavras: "Se estivermos certos, ao sugerir que esse sistema conceptual é em grande parte metafórico, então o modo como pensamos, o que experienciamos e o que fazemos todos os dias são uma questão de metáfora" (Lakoff \& Johnson, 2002, p. 46). Assim sendo, conceitos metafóricos, expressos na linguagem, também estruturam o que fazemos e exercem uma influência na compreensão do que fazemos, lembrando que "a essência da metáfora é compreender e experienciar uma coisa em termos de outra" (Lakoff \& Johnson, 2002, p. 48). Portanto, embora esteja convicta de que esse sistema conceitual não seja um determinante absoluto, acredito sim que ele esteja intimamente relacionado com o conceito de discurso que permeia esse estudo, qual seja, "formas reguladas de fala institucionalizada" (S. Jäger, 2012, p. 29) ou como define Margarete Jäger (no prelo):

forma e conteúdo de enunciados. E sua análise responde, grosso modo, à pergunta sobre o que é/foi, a um determinado tempo, dizível, como e por quem. Isso significa que, durante a análise, também sempre se tem em mente a pergunta sobre o que não foi ou não é dizível.

Considerando que o ser ou não dizível tem efeitos discursivos diretos sobre os momentos da prática social em questão, pois de certa forma define o que é norma e o que é desvio, e considerando ainda que a metáfora estrutura o que fazemos e a maneira como compreendemos o que fazemos, essas duas abordagens podem ser consideradas complementares e reflexivas. Sobre isso, e citando o exemplo da metáfora da discussão como batalha, Lakoff \& Johnson (2002, p. 48) acrescentam:

O conceito é metaforicamente estruturado, a atividade é metaforicamente estruturada e, em consequência, a linguagem é metaforicamente estruturada. $[\ldots]$

A linguagem da discussão não é poética, ornamental ou retórica; é literal. Falamos sobre discussão dessa maneira porque a concebemos assim - e agimos de acordo com o modo como concebemos as coisas.

Apesar de ser sempre questionável o que seria "literal" em contraposição ao "poético, ornamental ou retórico", sabe-se que tradicionalmente dividem-se os significados das palavras em denotativos e conotativos, entendendo-se o processo metafórico como uma estratégia de afastamento da literalidade ou da denotação, ou seja, de um "vínculo direto de significação que 
um nome estabelece com um objeto da realidade" (Houaiss, Villar \& Franco, 2009, p. 614). Entendo que Lakoff e Johnson (2002) propõem a quebra desse paradigma, de forma que todo processo de nomeação equivaleria a uma grande metáfora, sendo a literalidade, ou a denotação, no sentido tradicional algo que tampouco fuja à metáfora, e, eu acrescentaria, tampouco ao discurso histórica e geograficamente marcado.

No que diz respeito ao parto, embora trate-se de um evento fisiológico, sua constituição discursiva enquanto prática social, que envolve o dispositivo da assistência obstétrica, vai muito além do fisiológico e os aspectos de cunho social e cultural têm um papel importante no processo, no qual agimos (ou deixamos de agir) influenciadas/os pela maneira como o concebemos. Como defende Tornquist (2002, p. 489), não seria possível "pensar o parto como um evento além ou aquém da cultura, pois, como qualquer ação humana, o parto é também uma construção social”. Por isso, é relevante observar as metáforas encontradas nos textos, no intuito de buscar perceber e interpretar a maneira como estamos metaforizando, concebendo esse evento, para tentar entender as ações e atitudes aí envolvidas e/ou imaginar novas posturas e papéis possíveis, no caso de mudanças sociais e discursivas, ou uma nova conceituação metafórica da prática em foco. Lakoff \& Johnson (2002, p. 50) defendem que:

Uma vez que expressões metafóricas em nossa língua são ligadas a conceitos metafóricos de uma maneira sistemática, podemos usar expressões linguísticas para estudar a natureza de conceitos metafóricos e, dessa forma, compreender a natureza metafórica de nossas atividades.

Simone Diniz, pesquisadora da área de Medicina Preventiva, Saúde e Direitos Sexuais e Reprodutivos, Violência de Gênero, Gênero e Saúde Materna, Saúde Materno-infantil e Saúde Pública baseada em evidências, que coordenou, na região sudeste, o Inquérito Nacional Nascer no Brasil (2010-2012) e que chefia, desde 2012, o Departamento de Saúde Materno-infantil da Faculdade de Saúde Pública da USP, também reconhece a necessidade de compreensão das metáforas. Segundo ela,

[a] compreensão das metáforas e dimensões rituais na assistência ao parto, enquanto técnicas que instauram e explicitam relações intersubjetivas - de gênero, de classe, de raça, enfim, de assimetria -, pode não só nos ajudar a entender como essas relações de poder se mantêm, mas também imaginar novos rituais que reconheçam e propiciem o direito dos sujeitos envolvidos a uma negociação de relações mais saudáveis e fortalecedoras na cena fundadora da vida humana. (Diniz, 2001, p. 47)

Dito isso, passemos à citação de expressões metafóricas encontradas nos textos em questão. 
A metáfora militar aparece, por exemplo, de maneira bastante sutil, no relato de Laura, perceptível pela seleção lexical, quando ela justifica o porquê de ter optado pela cesárea quando soube que, optando pelo parto normal, não poderia ser acompanhada por seu parceiro, ficando sozinha com a "tropa médica". Neste fragmento percebemos que, no que diz respeito ao aspecto autobiográfico do relato, Laura escreve desde uma perspectiva anterior e ainda desinformada, momento anterior a sua "conversão" em uma pessoa que sabe sobre o parto e suas possibilidade e "perigos", contrapondo a identidade da autora à identidade da protagonista do relato. Em suas palavras, no fragmento em (21):

Bom! Por eu não ter me informado antes, meu filho nasceu de cesariana. O meu plano só cobria um hospital para partos em toda a [cidade] e esse hospital não liberava a presença do pai nem no pré-parto e nem durante o parto. No pré-parto eu teria de ficar em uma sala junto com várias outras mulheres passando pela mesma situação. Durante o parto seríamos eu, meu filho e a tropa médica.

Ao categorizar a equipe obstétrica potencialmente como "tropa médica", Laura compreende e, potencialmente, experiencia a assistência obstétrica como uma operação militar. Pressuposta está aí adversidade entre Laura e seu filho, de um lado, e a tropa, do outro lado. Considerandose que a ampliação desse campo semântico nos conduziria à representação do parto como um embate urbano entre população civil e policiais, no qual historicamente temos presenciado a violência institucional, empreendida por policiais, e a agressão sofrida pela população, especialmente pela população negra e periférica das grandes cidades brasileiras, e conhecendo Laura e sabendo que ela mesma é uma integrante desse grupo, só podemos interpretar que para ela o parto normal possível foi concebido em concordância com esse quadro e, levando isso em consideração, é perfeitamente compreensível a sua decisão estratégica e racional, dadas as condições imediatas em que se encontrava, de optar por uma cesárea, durante a qual poderia ser acompanhada e defendida dessa tropa por seu companheiro, homem e branco. Possivelmente, porque intui que, como escreve Diniz (2009, p. 322), "quando as mulheres têm um acompanhante, elas tendem a ser tratadas melhor".

Conforme defende Martins (2006), a violência obstétrica não pode ser entendida sem que levemos em conta a interseccionalidade de fatores constitutivos, genéricos, sociais e raciais, embora muitas/os pesquisadoras/es simplesmente se recusem a levar esses fatores em consideração. $\mathrm{O}$ autor escreve que: 
Juntamente com as questões sócio-econômicas emerge a questão racial. A análise é difícil de ser realizada por causa da dificuldade de entendimento da classificação raça/cor, já que existem várias tendências: por cor, por ascendência, por estratos sociais, havendo até quem acredite que não deva existir classificação. A maioria dos pesquisadores simplesmente se recusa a levar raça em conta quando são consideradas as causas da pobreza e da falta de oportunidades.

A falta de entendimento das diferenças e diferenciais raciais/étnicos, da opressão de gênero e do racismo na manutenção, recuperação e perda da saúde em uma sociedade classista provoca "espanto" quando se menciona a saúde da mulher negra. A despeito dos diferentes referenciais, os dados evidenciam que as mulheres negras vivem em piores condições de vida e saúde.

Maria Victoria Benevides, ainda em 1985, num artigo cuja atualidade é impressionante, escreve sobre a violência policial, profundamente marcada por uma discriminação interseccional, e agravada com a militarização da polícia:

O velho ditado afirma que, no Brasil, "a polícia só prende os três p: pobre, preto e prostituta". O cinismo reflete não apenas a perversidade de uma sociedade profundamente viciada pela discriminação racial, social e sexual, como a evidência da distorção do papel da polícia. Esta deixa de ser uma instituição voltada para a segurança pública - isto é, de todos - para tornar-se o braço armado e repressor, de alguns, a classe dominante e seus aliados. É claro que a militarização da polícia só agravou esta realidade. (Benevides, 1985 , p. 25)

Considerando-se que, para o senso comum, de nossa sociedade fortemente marcada pelo machismo, a denominação prostituta justificaria o desrespeito a direitos humanos básicos e a responsabilização da vítima por agressões sofridas, como, por exemplo, em caso de estupro, e que às mulheres em geral é muito facilmente atribuída essa classificação, poderíamos dizer que o ditado de fato corresponderia a dois "p"s e um "m", de "mulher". E é evidente que o prender presente no ditado é o prender arbitrário, a violação de direitos, cuja primeira vítima seria a mulher, negra e pobre, por preencher as três categorias preferenciais do sistema.

Tendo em vista esses dados, deduz-se facilmente que uma mulher negra e periférica, ao representar o parto normal como um encontro com a "tropa médica", não está com expectativas positivas com relação a esse encontro, muito pelo contrário, em seu imaginário, esse encontro é negativo o bastante, a ponto de fazer com que ela nem ousasse tentar esse caminho, buscando uma saída possível na opção pela cesárea, mesmo contrariando seus princípios e crença na preeminência do parto vaginal. Opção essa muitas vezes também escolhida porque as mulheres, além de desconhecerem os riscos da cesariana, muito já ouviram relatar sobre o sofrimento das mulheres em trabalho de parto nos hospitais, sem que haja uma distinção entre a dor fisiológica 
e aquela causada pela violência obstétrica de rotina, ou institucional, como a definiu Aguiar (2010). Como diria Simone Diniz (2009, p. 321), trata-se antes de uma busca por dignidade:

A demanda pela cesárea, no Brasil, seria sobretudo uma demanda por dignidade, já que o modelo de parto "normal" típico é intervencionista e traumático. Trata-se de "uma escolha entre o ruim e o pior", entre duas formas de vitimização. Nas palavras de uma usuária, "se tiver que cortar é melhor cortar por cima, porque em baixo é uma área mais nobre".

A metáfora militar empregada por Laura, em (17), também faz lembrar a questão da formação médica, descrita pelo sociólogo mexicano Roberto Castro (2014) em referência a seu país, mas que se aplicaria também ao contexto brasileiro, relativo a um habitus médico autoritário, moldado à semelhança de instituições militares, formando as/os estudantes para a violência institucional na atenção obstétrica.

A metáfora da mecanização.

Voltando às metáforas, Laura segue, em seu relato, ressaltando a desumanização do momento do parto, ou pelo menos da assistência ao parto, por meio do conceito de "mecanização" metaforicamente aplicado à assistência obstétrica, como é reproduzido em (22):

$\mathrm{Na}$ época eu achava que isso era uma coisa óbvia, que no nascimento de crianças o pai poderia acompanhar mesmo sendo um parto normal. Não sabia que a situação do parto no Brasil estava tão "mecanizada". Tudo o que passei ficou em minha memória.

A situação mecanizada se contrapõe à condição humana; a metáfora pressuposta do sistema como máquina corresponde muito diretamente à descrição de "obstetrícia de linha de montagem" como descrita por Diniz \& Chacham (2006, p. 83), e da consequente "crueldade terapêutica" (Pérez \& Gérvas, 1999), na qual intervenções em cascata são realizadas em completa desconsideração das necessidades individuais, fisiológicas e humanas de cada mulher assistida.

\section{A metáfora da montanha russa.}

Além das metáforas já mencionadas, afetas sobretudo à caracterização da assistência obstétrica, há também as metáforas mais afetas à autoidentificação, da mulher e de seus processos fisiológicos. Vejamos a seguir, em (23), a metáfora da montanha russa, que aparece no relato de Tânia sobre seu parto domiciliar: 


\begin{abstract}
Ah, e o melhor estava por vir, em uma ou duas horas, meu TP ativo começou! Eu comecei a sentir as tais contrações doloridas e pulamos todas de felicidade quando começou! Sim! Parece loucura, mas eu estava muito feliz com minhas dores. Era como se, durante esse tempo todo eu estivesse na fila para "aquela" montanha russa incrível, e agora, com as contrações e dores, eu tivesse acabado de embarcar no carrinho. Estava eufórica. Aliás, todas nós estávamos.
\end{abstract}

Como já dito antes, a questão da dor é recorrente nos textos, aliás uma busca pelos itens lexicais “dor", "dores", “doer", “doía", “doída/o" ou "dolorida/o" resultou em 112 ocorrências distribuídas por 20 dos 23 textos analisados. Ou seja, em quase todos os textos a dor é mencionada, representada com mais ou menos intensidade ou repetição. Diante desse quadro, essa metáfora é especialmente relevante, pelo simples fato de mencionar algo que parece quase indissociável da experiência de parir; embora haja registros de mulheres que afirmam ter parido sem dor, podemos quase dizer que elas seriam a exceção que confirmaria a regra.

Portanto, uma metáfora que associa a dor à adrenalina, a um espaço de diversão, a um brinquedo disputado, ainda que provocador de fortes emoções, medo, e, quiçá, outras sensações desagradáveis, como náuseas e arrependimento por ter embarcado, constitui uma representação forte e contradiscursiva em relação ao discurso hegemônico sobre a dor, muito influenciado pelos escritos bíblicos, nos quais a dor do parto seria uma castigo imputado às mulheres por Deus devido à insubordinação de Eva à determinação divina de não comer do fruto proibido nos jardins do Éden. A dor, como aspecto de um momento de diversão e adrenalina, como um presente ansiosamente aguardado e não como castigo a ser sofrido, é uma representação que pode ter um efeito bastante distinto na forma como as mulheres estabelecem suas expectativas com relação ao momento parto, especialmente se concordamos com Lakoff \& Johnson (2002, p. 48), sobre agirmos "de acordo com o modo como concebemos as coisas". Lembro que, defendendo isso, não quero em nenhum momento defender a dor em si, tampouco romantizar a dor, mas reconhecer mais uma vez o parto como um evento que além de biológico é também sócio-histórico e culturalmente conformado. Assim, acredito que essa metáfora pode indicar a possibilidade de outra lida com essa dor, por exemplo, nos termos do "Ideário do Parto sem Dor”, dos anos 1950, quando “obstetras de vanguarda preocupados em minimizar as dores do parto e transformá-lo em um evento mais prazeroso, [propunham] para isso o uso de técnicas comportamentalistas de controle da dor" (Tornquist, 2002, p. 485). 
3.9. (Auto)responsabilização das mulheres pela violência sofrida.

Outro tema recorrente nos textos é a (auto)responsabilização das mulheres ou de seus corpos falhos pela intervenção/violência sofrida, por exemplo, como aparece na carta ao obstetra na qual Aída relata a forma como seu médico justificou sua recomendação para uma cesárea imediata, fragmento reproduzido em (24):

Te liguei de manhã, avisando que perdi o tampão e sentia algumas cólicas. Você me mandou ir para a [hospital]. Fui e estava em pródromos de trabalho de parto. A enfermeira me examinou e depois disse que você viria falar comigo pessoalmente. Cerca de 40 minutos depois você chegou e disse que meu colo era grosso, duro e posterior, o que significaria um longo trabalho de parto, e que poderia acarretar em sofrimento fetal para minha filha. Aconselhou uma cesárea imediata, para assim evitar que ela nascesse mal.

Note-se que devido a uma característica do corpo de Aída que poderia acarretar sofrimento fetal, e não por qualquer outro motivo, o médico teria aconselhado uma cesárea imediata.

Nara diz, em (25), que não poderia ter ignorado os sinais ainda durante o pré-natal, numa situação em que passou quatro dias internada por causa de um sangramento, que seriam a pista para o mau atendimento que teria também durante o parto, mas o faz sem deixar de mencionar algumas das razões para essa ignorância:

Suas visitas relâmpagos de alguma forma me incomodavam, e começa aí a sequência de sinais que eu não poderia ter ignorado, mas as enfermeiras do hospital [...] insistiam na qualidade impecável do seu profissionalismo e como eu tinha sorte de ser sua paciente, pois nós éramos muitas e o senhor precisava manejar o seu tempo com destreza.

$[\ldots]$

Uma vez chegou a dizer que estava contente com o meu ganho de peso, uma vez que eu havia emagrecido muito no início da gravidez. Eu engordei $24 \mathrm{~kg}$ na gravidez. Era outro sinal que eu não podia ter ignorado, de que eu não seria tratada como um indivíduo.

$[\ldots]$

Eu devia ter desconfiado desde o início, taí outro sinal, a prateleira da sua sala é cheia de fotos de bebês e mães, todos cirurgicamente removidos. Não me lembro de ver nenhuma foto de uma mulher sorrindo ao seu lado em posição de igualdade. Estavam todas deitadas, amarradas, anuladas nos nascimentos dos seus filhos. Assim como eu, cinco dias depois dessa consulta fiquei.

Da maneira como expressa essas observações, Nara assume para si a responsabilidade de ter sofrido uma cesárea desnecessária, ao dizer "eu não poderia ter ignorado", "eu não podia ter ignorado", "eu devia ter desconfiado". O papel do médico e da estrutura hospitalar são apenas 
aludidos, mas em segundo plano, o foco da responsabilização é ela mesma, ou qualquer mulher na mesma situação.

\subsection{Volta por cima.}

Coincidentemente, segue-se à questão da (auto)responsabilização da mulher ou de seu corpo pela violência sofrida, na sequência dos temas mais mencionados, aquilo que chamei de "a volta por cima". Esse tema se configura na representação e autoidentificação em que as mulheres falam da superação após uma vivência negativa, uma experiência em que foram vítimas da violência obstétrica. Sobre isso, Aída confessa:

(26) Na gravidez seguinte me eduquei, descobri que fui enganada, aprendi que colos são duros, grossos e posteriores antes do trabalho de parto começar, procurei outro médico, esse com fama de atender partos normais, e finalmente pude ter o parto normal que eu já queria quando era sua paciente. Com o mesmo colo grosso, duro e posterior, nas primeiras horas de trabalho de parto. $[\ldots]$

Depois disso virei uma ativista ferrenha contra as cesarianas enganadas. Há 13 anos eu milito pelo direito das mulheres não serem operadas sem necessidade, para conforto de seus médicos. Capacitei-me como doula, atendi mais de 400 partos como doula.

[...]

Minha vida se transformou para melhor, para muito melhor. Graças à violência obstétrica que eu e minha filha sofremos em 1997, hoje eu sou outra mulher. Eu posso calcular por alto que, graças à cirurgia que me foi imposta naquele dia, eu já devo ter evitado que umas 10 mil caíssem na mesma armadilha, através dos meus textos, website, meu livro publicado pela UNESP minha militância.

$[\ldots]$

Portanto hoje, 15 anos depois da cicatriz deixada por seu bisturi, eu posso dizer com um sorriso no rosto:

Muito obrigada!

Após “descobrir" ter sido enganada, Aída diz ter aprendido, procurado outro médico e ter tido o desejado parto normal. Ademais, tornou-se ativista e doula, militante pelos direitos das mulheres. Segundo ela, sua vida se transformou para melhor e, graças à violência sofrida, ela pôde evitar um grande número de cesáreas desnecessárias. Tudo isso a permitiria agradecer, com um sorriso no rosto, ao médico que a operou ainda que somente 15 anos depois do ocorrido.

Nara representa, no fragmento em (27), sua "volta por cima" pela menção do perdão, da superação, e pauta a instrumentalização da experiência negativa para alertar outras mulheres: 
quer essa maluca? Em primeiro lugar eu quero te perdoar. E depois essa carta tem também efeitos terapêuticos, pois depois de três anos consigo escrevê-la sem nenhuma lágrima nos olhos. Em terceiro lugar eu tenho me realizado usando minha própria experiência para alertar outras mulheres. Vamos ver se eu consigo atingir meus objetivos com ela. Algumas coisas precisam então ser ditas.

Nara e Aída revelam com seus textos evidências desse projeto de emancipação coletiva que envolve um grande número de mulheres, um projeto identitário que, nos termos de Castells (1999, p. 24), podemos relacionar à resistência e ao ativismo em prol de mudança no fluxo do discurso que orienta a prática social do parto, fomentando estratégias de combate à violência obstétrica institucionalizada, também como forma de cura das chagas individuais.

\subsection{A influência das histórias compartilhadas.}

Uma questão que eu trazia comigo desde o início do projeto dizia respeito à influência de histórias compartilhadas na visão que as mulheres teriam do processo do gestar e do parir, assim como da naturalização, ou não, das práticas obstétricas vigentes. Motivada por minha própria experiência de mulher que consentiu uma episiotomia e que acredita que teria agido diferentemente, caso, em lugar de ter ouvido que se tratava de um "picozinho" na vagina, tivesse ouvido que era um "corte" na vagina, uma "intervenção cirúrgica" que pode exigir cerca de 15 pontos de sutura. De fato, encontrei nos textos analisados referências a essa influência, ao saber e às crenças compartilhadas entre mulheres, de todas as idades e em diferentes momentos da vida. Lívia registrou, em (28), que:

Em uma conversa com uma amiga nossa, mãe dedicada e militante, ela disse uma frase que tocou meu coração, pois eu vi em seus olhos muito sentimento: "Quem me dera alguém tivesse me alertado em minha primeira gestação. Não teria sido submetida a uma cirurgia desnecessária". Isso abriu meus olhos e minha cabeça para buscar o significado da humanização do parto.

O que ouviu de uma amiga, com muito sentimento nos olhos, fez com que Lívia abrisse os olhos e a cabeça, e, como ela conta depois, ter parido da maneira como queria. Elena, por sua vez, relata, em (29), ter tido sorte por ter conversado com uma conhecida que tinha parido assistida por uma parteira, a mesma parteira que depois apararia seu filho:

Tive a sorte de conversar com a Juliana, mãe de meninas na mesma escola q a Lara, minha filha, que teve o parto acompanhado pela Agnes. Tivemos uma conversa muito boa e ela me passou o contato. 
Essa troca entre mulheres é a troca de um conhecimento, de saber-poder. Como lembram Borges, Pinho \& Santos (2009, p. 376), “conhecimento é o resultado de práticas organizadas social e culturalmente que mobilizam diferentes recursos materiais e intelectuais contextualizados", e, embora elas não digam isso, acho que poderíamos nesse caso falar de intelectuais orgânicas, nos termos de Gramsci (1999, p. 103), que define as/os intelectuais pelo lugar e pela função que exercem no conjunto das relações sociais.

Por intelectuais não se deve compreender somente os normalmente designados por esse título, mas, em geral, toda a massa social que exerce funções organizacionais no sentido mais amplo, tanto no campo da produção quanto no cultural e no político-administrativo.

Em seu texto sobre as representações sociais das parteiras tradicionais e o seu modo de cuidar, Borges, Pinho \& Santos (2009), mencionam a forma como se dá a assistência por essas mulheres, requisitadas devido ao reconhecimento e a confiança que nelas deposita a comunidade, confiança que confere segurança. A menção de Lívia ao "sentimento" nos olhos de sua amiga, como determinante na sua mudança de atitude, me fez lembrar a rede de subjetividade pautada por essas autoras (Borges, Pinho \& Santos (2009, p. 378), afeta ao partejar das parteiras tradicionais e à relação de compromisso que se estabelece entre elas e a comunidade:

Nessa relação de compromisso, constrói-se uma rede permeada pela subjetividade, em que se criam afetos, vínculos e se desenvolve solidariedade, que no processo parturitivo são potencialmente terapêuticos. Essa subjetividade é pouco considerada pela ciência hegemônica, que não reserva espaço para o não-técnico: a "nossa cultura ocidental nos centra emocionalmente na valorização da intencionalidade, produtividade e controle" (Maturana \& Zöller, 2004, p. 140).

Como as autoras sustentam, a subjetividade, os afetos, os vínculos e a solidariedade são potencialmente terapêuticos. E, como nos permitem dizer os últimos fragmentos citados, terapêuticos individual e sistemicamente, no sentido de garantir a cada mulher um momento do parto melhor assistido, ou a cura das feridas deixadas pela má assistência, mas também no sentido de, numa associação entre mulheres, que, como alguém já disse, "são como águas que crescem ao se encontrar", mudam o curso do rio discursivo que orienta ou permite a prática obstétrica como não a desejamos. Nesse movimento, o compartilhar das histórias exerce um papel essencial. 
3.12. O corpo que pede.

Algo que também aparece nos textos é a personificação do corpo enquanto agente que pede, que requisita, que quer e precisa ser ouvido. Vejamos, por exemplo, esse fragmento escrito por Bertha, em (30):

Parir pode curar e eu ainda não sei bem exatamente quais das feridas recebeu o remédio, mas sei que o alívio foi imediato. $\mathrm{O}$ corpo, tendo o que pediu, se acalmou. O coração ficou leve.

$[\ldots]$ Quiseram me fazer massagem, o toque aumentava a dor. Era meu corpo me dizendo: agora o negócio é entre a gente e mais ninguém.

$[\ldots]$

Ninguém me mandou fazer força quando eu não queria, fora de hora. Pra quê? Meu corpo trabalhava sozinho, a mim cabia sentir, consentir, urrar e aguardar.

O corpo de Bertha pede, recebe e se acalma, o corpo diz e trabalha sozinho, enquanto a ela cabe sentir, consentir, aguardar. Esse resgate do corpo ao primeiro plano do processo corresponde a um retorno ao natural, que conforme Tornquist (2002, p. 487):

aparece com freqüência no ideário [do movimento pela humanização] [...]. A argumentação alternativa e naturalista aproxima-se das concepções de fisiologia humana e do parto, tão caras à concepção biomédica. A recusa que se faz ao modelo tecnocrático de atenção ao parto e ao nascimento, visto como emblemático do modo ocidental de pensar e de viver, implica questionar o predomínio da técnica e da cultura sobre procedimentos tidos como naturais, postulando-se, no limite, um retorno a uma vida mais natural.

Considerando-se a oposição entre corpo e mente construída historicamente, e que durante a Idade Média atribuía ao corpo o lugar dos defeitos e pecados que geravam a doença, sendo a alma o lugar dos valores supremos, como espiritualidade e racionalidade (Fava, 2000 apud Castro, Andrade \& Muller, 2006, p. 40); considerando-se o dualismo ontológico proposto por Descartes, o pai do racionalismo, quando defendeu, já na idade moderna, a distinção entre mente e corpo, (Grosfoguel, 2016, p. 29), corpo esse que seria lugar do irracional, avesso à necessidade do pensar enquanto condição de existência, conforme o lema cartesiano "penso, logo existo"; e considerando-se que essa dicotomia ainda continua, de alguma forma, vigente em nosso imaginário, associada à já mencionada “visão pessimista da natureza feminina", cuja falha fisiologia teria justificado a apropriação do corpo das mulheres pela medicina; considerando-se todos esses fatores, a representação desse corpo, com "voz e vez", influencia discursivamente a recuperação da autonomia pelas mulheres. 
Tudo isso é especialmente relevante se entendemos esse corpo em associação com saberes, conhecimentos femininos, que têm sido historicamente inferiorizados pelo sexismo epistêmico constitutivo das instituições modernas de saber, as universidades ocidentais, as mesmas que formam, atualmente, as/os profissionais da medicina que atuam na assistência obstétrica hegemônica. Sobre esse sexismo, Grosfoguel (2016, p. 28) sustenta que

o conhecimento produzido por mulheres (ocidentais ou não ocidentais) é também visto como inferior e fora do elenco do cânone do pensamento. As estruturas fundacionais do conhecimento das universidades ocidentalizadas são epistemicamente racistas e sexistas ao mesmo tempo.

A associação desse corpo das mulheres a um saber proibido, ilegítimo, ou mesmo perseguido também não é uma novidade. Santos descreve os epistemicídios - "a destruição de conhecimentos ligados à destruição de seres humanos" (Santos, 2010 apud Grosfoguel, 2016) - que se sucederam desde o século XVI:

1. contra os muçulmanos e judeus na conquista de Al-Andalus em nome da "pureza do sangue";

2. contra os povos indígenas do continente americano, primeiro, e, depois, contra os aborígenes na Ásia;

3. contra africanos aprisionados em seu território e, posteriormente, escravizados no continente americano; e

4. contra as mulheres que praticavam e transmitiam o conhecimento indoeuropeu na Europa, que foram queimadas vivas sob a acusação de serem bruxas

Grosfoguel (2016, p. 42) acrescenta que esse quarto epistemicídio, contra as mulheres, diferiu em um aspecto dos demais, pois o conhecimento das mulheres estava sobretudo em seus corpos e não em livros, fato que as levou às fogueiras:

Ao contrário do que ocorreu com o epistemicídio contra as populações indígenas e muçulmanas, quando milhares de livros foram queimados, no caso do genocídio contra as mulheres indo-europeias não houve livros queimados, pois, a transmissão de conhecimento acontecia, de geração para geração, por meio da tradição oral. Os "livros" eram os corpos das mulheres e, de modo análogo ao que aconteceu com os códices indígenas e com os livros dos muçulmanos, elas foram queimadas vivas.

Portanto, um reconhecimento dos saberes inscritos nos corpos das mulheres, sejam eles fisiológicos ou histórico-culturais, a sua representação e revalorização revelam para mim uma estratégia emancipatória contradiscursiva verificável nos relatos analisados. 
3.13. A pluralidade do medo.

Zygmunt Bauman (2008), em sua obra Medo líquido, escrita na primeira década deste século, versa sobre os "muitos medos que entram em nossa vida juntamente com os remédios sobre os quais muitas vezes você ouviu falar antes de ser atemorizado pelos males que esses prometem remediar". E a cesárea, assim como outras intervenções de rotina, poderia ser entendida como um remédio assim, como um remédio preventivo (!) diante dos badalados "perigos do parto". Entretanto, os perigos concretos do parto devem ser prevenidos muito anteriormente, com um atendimento pré-natal de qualidade, e os perigos inventariados pelos "terroristas" do parto normal, como assim os chamou Tânia ${ }^{19}$, quase sempre se configurem como "indicações fictícias para cesárea", conforme definidas no blog pessoal da obstetra e pesquisadora, Melania Amorim $^{20}$. A esta altura talvez seja importante ressaltar que não considero essa atuação "terrorista" de maneira alguma como uma atitude intencional individual de profissionais imorais, antes entendo essa atitude como parte de uma evolução sistêmica, que talvez possa ser compreendida como algo que se insira na banalidade do mal teorizada por Hannah Arendt, que acredita ser possível que o mal dependa não de impulsos malignos, mas pura e simplesmente da falta de reflexão sobre as motivações e as consequências dos próprios atos. Com relação a isso, Arendt (1991 apud Silva, 2005, p. 21) se questiona: "será possível que o problema do bem e do mal, o problema de nossa faculdade para distinguir o que é certo e o que é errado, esteja conectado com nossa faculdade de pensar?"

Como no caso das intervenções em cascata que ocorrem quando a assistência obstétrica se constitui como uma linha de produção maquinal (Diniz \& Chacham, 2006), a assistência obstétrica violenta num sentido mais amplo configura um efeito cascata cuja base sistêmica é o sistema de produção capitalista e a desumanização do trabalho em si, devido a seu foco, não nos seres humanos e em sua realização, mas no capital e na mais valia a qualquer preço, sendo que nesse processo, não só mulheres são objetificadas, mas todos os outros seres humanos envolvidos, embora o aspecto da interseccionalidade deva sempre ser considerado. Esse sistema, essa economia de consumo, como defende Bauman (2008, p. 14):

... depende da produção de consumidores, e os consumidores que precisam ser

19 Ver mais na seção 4.1.

20 http://estudamelania.blogspot.com.br/2012/08/indicacoes-reais-e-ficticias-de.html, acesso em 26 de setembro de 2016. 
produzidos para os produtos destinados a enfrentar o medo são temerosos e amedrontados, esperançosos de que os perigos que temem sejam forçados a recuar graças a eles mesmos (com ajuda remunerada, obviamente).

Essa produção de consumidoras/es, constituídas/os por seus medos, é um processo discursivo, e em processos discursivos, como defende Regis (2015, p. 4740), baseando-se em Siegfried Jäger (2012),

vale que todas/os contribuímos para sua composição, ainda que nenhum de nós tenha realmente desejado ou planejado o que aconteceria de fato, em que resultariam nossas ações. E diante dos discursos vigentes e da consequente constituição discursiva do sujeito, os espaços e as possibilidades para ações individuais são limitados. Partindo-se desse ponto de vista, podemos nos questionar quanto às responsabilidades de todas/os as/os envolvida/os, sem que nos preocupemos em primeira instância com a atribuição de culpa, sem situar pessoas e grupos a priori como sendo vítimas ou algozes. Desta maneira, talvez seja possível fortalecer um diálogo construtivo para a constituição de uma nova hegemonia discursiva, na qual a violência institucionalizada contra a mulher não seja mais normal.

Enfim, embora, como afirma Bauman, (2008, p. 31) "as oportunidades de ter medo [estejam] entre as poucas coisas que não se encontram em falta nesta nossa época", acredito ser possível sim, por meio da análise e da reflexão discursiva, rever a (in)fundamentação de determinados medos e, oxalá, sem temer, reforçar os discursos da coragem, mesmo diante da incertezas inerentes à vida, especialmente no tocante ao evento do parto.

Seguindo com as questões representadas nos relatos e cartas, o medo também foi um tema recorrente. Sobre uma faceta desse medo, o medo de não conseguir parir, Anita escreveu, em (31):

(31) A água quente deu uma aliviada nas contrações, mas também diminuiu minha pressão. Com isso os batimentos do coração da Iaiá começaram a diminuir também, e eu dei uma desesperada. Não conseguia respirar direito, achei que eu fosse apagar. Nessa hora, senti medo. Senti medo durante o parto. Uma parte minha ainda não acreditava completamente na minha capacidade de parir, e isso foi muito real pra naquele momento.

Janaína, por sua vez, fala, em (32), de um medo indeterminado, mas várias vezes mencionado em seu relato, um medo a ser vencido, um medo que impedia, medo que se intensificava, medo misturado com cansaço e força, medo a ser enfrentado, medo que antecede a alegria:

(32) Passei os 9 meses me preparando para muitas coisas, mas, principalmente, para vencer um medo que até hoje não descobri direito de que era....(acho que 
é algo para pensar o resto da vida).

$[\ldots]$

Desde a semana 40, a cada mudança de lua, eu sentia que poderia ser a hora, como se a natureza estivesse agindo e, talvez, de alguma forma, meu "medo" impedindo...

$[\ldots]$

...não achava que estava indo bem... estava doendo para caramba... e meu medo só se intensificando!

$[\ldots]$

Comecei a sentir vontade de empurrar. Que medo tão grande sentia. Neste momento, era uma mistura de cansaço, medo, força, de tudo...

$[\ldots]$

Gritos eram inevitáveis. Fazia força, mas elas acabavam em gritos. Dois gritos seguidos de enfrentamento do medo. Gritava como um bicho!!! Não lembro como, mas senti o bebê chegando, a cabeça me queimando e logo o resto do corpo me aliviando. Que sensação deliciosa e inesquecível. Me entregaram então o bebê. [...] UAAAAAAAAAU que alegria...

Zygmunt Bauman (2008, p. 31) entende que:

As oportunidades de ter medo estão entre as poucas coisas que não se encontram em falta nesta nossa época, altamente carente em matéria de certeza, segurança e proteção. Os medos são muitos e variados. Pessoas de diferentes categorias sociais, etárias e de gênero são atormentadas por seus próprios medos; há também aqueles que todos nós compartilhamos - seja qual for a parte do planeta em que possamos ter nascido ou que tenhamos escolhido (ou sido forçados a escolher) para viver.

Como esse autor escreve, são muitas as oportunidades para temer, tenham essas oportunidades bases concretas ou não; entretanto, esses medos não seriam meramente universais: critérios distintivos, como gênero, também influenciariam o teor desses medos. E aqui falamos de medos definitivamente marcados pela questão de gênero, um medo que só pode acometer especificamente a mulheres confrontadas com o parto e a maternidade.

Sobre essa vertente dos medos de nossa época, Pereira, Franco \& Baldin (2011, p. 386) afirmam, baseando-se em entrevistas realizadas com mulheres no terceiro trimestre de gestação, que o medo também era um aspecto bastante recorrente em suas falas, sobretudo o medo da dor. Ademais, as pesquisadoras reforçam a argumentação de que a forma como as mulheres entendem seu papel no mundo e no parto, e o contexto sociocultural têm relação direta com a dor vivenciada durante o parto, objeto do medo de suas entrevistadas. E eu acredito que podemos fazer a mesma afirmação com relação ao medo vivenciado durante o parto, considerando-se que o medo encontrado nos relatos e cartas não foi, em nenhum fragmento, o medo da dor (embora algumas vezes fosse o medo impulsionado pela dor), mas ainda assim era medo. Medos distintos e indefinidos que eu ousaria classificar como sendo, no fundo, o medo 
de um desfecho infeliz para o parto. Especialmente no caso dessas mulheres emancipadas, que se atreveram a buscar o parto contra-hegemônico para seu contexto, um parto vaginal no país das cesáreas: o medo do fracasso.

Dias (2007), em sua tese doutoral, O Renascimento do Parto: discurso e identidade, baseandose em Adam \& Herzlich (2001 apud Dias, 2007, p. 125), sustenta que, quando o aspecto corporal apresenta uma relação estreita com o aspecto moral, como é o caso do parto, isso exerce uma grande influência no processo de autoidentificação subjetiva das mulheres. Portanto, conforme essa autora:

podemos pensar que qualquer acontecimento que seja interpretado pela sociedade como um problema na gravidez e/ou no nascimento poderá ser interiorizado, pela mulher, como uma experiência negativa para sua autoimagem. [...] como discutimos anteriormente, a identidade da mulher durante a gravidez encontra-se em forte transição, o que nos faz pensar que essa possível associação entre a maneira como se dá à luz e a emergência de uma nova identidade, qual seja a de mãe, possa ser repleta de conflitos, especialmente, naqueles grupos de grávidas que se 'empoderaram' durante a gravidez, uma vez que, além de terem de lidar com o 'problema' em si (um parto traumático, uma cesárea desnecessária, um aborto, um parto prematuro, ou o óbito do bebê), a mulher traz o acontecido para a composição de sua autoimagem, como se ela fosse a culpada ou a única responsável pelo ocorrido. (Dias, 2007, p. 125)

Essa "autoimagem" a ser construída/mantida, como outros ideais modernos, muitas vezes busca a perfeição, a infalibilidade. Simone de Beauvoir (apud Pereira, Franco \& Baldin, 2011, p. 386) sugere, nos idos de 1949, que, apesar dos avanços das pautas feministas, a mulher em nossas sociedades continuaria almejando corresponder à exigência de perfeição esperada por outrem no exercício de papéis como o de dona de casa, de esposa ou mãe. E essa seria, a meu ver, uma maneira ainda atual de interpretar esse medo declarado nos textos de minhas colaboradoras, sem que, com isso, eu queira dizer que esse medo seja algo necessariamente indesejável ou a ser evitado. Antes acredito que seja um medo a ser acolhido para que seus efeitos negativos sejam minimizados.

Como Bauman (2008, p. 9) afirma que "o medo é um sentimento conhecido de toda criatura viva" e que "os seres humanos compartilham essa experiência com os animais", permitam-me agora encerrar este capítulo com mais um de tantos outros temas que poderiam ser aqui incluídos, com mais uma metáfora: a analogia com a atuação animal. 
3.14. A metáfora animal.

Para começar, cito a seguir uma passagem do relato de Bertha, quando ela agradece também àquelas pessoas que não acreditaram nela, ou na sua capacidade de parir, no fragmento em (33):

Como não poderia deixar de ser, fica também um agradecimento mais do que especial a todos que, em qualquer etapa da minha gravidez, duvidaram de mim, que quiseram me atrapalhar, que me desmotivaram, que me fizeram chorar, que não acreditaram nas minhas palavras, que me machucaram, que me viraram as costas, que se aproveitaram da minha fragilidade, que quase me fizeram acreditar que eu estava enlouquecendo. Ao longo da vida, vocês não foram os primeiros a me fazer querer provar pra mim mesma o quanto sou forte. Depois desse parto, não preciso mais de prova nenhuma.

Sou mãe. Sou leoa. Pari. Renasci. Venci. E isso é só apenas o começo.

Enfrentadas as adversidades, Bertha se afirma "leoa", num processo metafórico de identificação com esse animal mamífero de grande porte, que representa a bravura e a nobreza em diversas culturas. Leoas são os únicos felinos que vivem em bandos, inclusive caçando cooperativamente. As leoas também têm um vasto repertório de vocalizações, seu rugir pode ser ouvido a distâncias de até oito quilômetros (Wikipedia, 2016). Apesar de sua agilidade e força, as leoas estão atualmente entre as espécies consideradas vulneráveis pela Lista Vermelha da União Internacional para a Conservação da Natureza e dos Recursos Naturais (IUCN, 2016), devido a seu declínio no quantitativo populacional. Considerada a condição da mulher que pare naturalmente no contexto urbano da classe média brasileira, comumente organizada em "bandos" de solidariedade, permitindo-se vocalizações ou um rugir estrondoso que comunica sua presença, a personificação da força e da vulnerabilidade a um só tempo, além da já mencionada busca pelo natural e instintivo perdido ou em extinção, nada poderia ser mais emblemático e simbólico dessas mulheres que a metáfora da leoa.

Concluída, enfim, essa análise estrutural, passemos no capítulo seguinte ao momento microanalítico, enfocando mais detalhadamente dois relatos de parto que nos permitem aprofundar os enunciados sugeridos pelos nós temáticos resultantes desta primeira etapa da análise. 


\section{CAPÍTULO 4 Análise fina. Relatos de parto.}

Demorei a relatar o caso por ser algo que ainda me machuca. Me machuca pela fraqueza de não ter conseguido o meu propósito, de sentir-me fraca, despreparada no momento que acreditava estar confiante, de ter permitido que isso tudo ocorresse...

Espero que lhe tenha contribuído de certa forma.

Abraços e bom trabalho de conclusão. Que você possa ser iluminada para fazer a diferença!

(Ivana)

Neste capítulo, passo então à etapa da análise linguística mais minuciosa de dois relatos de parto, à etapa chamada por Margarete Jäger Feinanalyse, análise fina ou microanálise. Com relação ao teor da microanálise, Margarete Jäger a define como sendo um passo analítico que "trata tanto do conteúdo quanto da estrutura textual, abrangendo as estratégias de fala e a argumentação assim como os meios sintáticos de que os/as participantes discursivos/as se servem” (M. Jäger, 1996, p. 53).

Além de seguir a sugestão de M. Jäger, analiso estes relatos com a crença de que pautar a análise em um único documento permite a realização de uma análise qualitativa em profundidade, sendo que cada caso é considerado pertinente em sua singularidade, e investigado nas relações que necessariamente realiza com o feixe discursivo que integra, com as práticas sociais que o compõe. Entendo que mesmo um único texto pode ser muito representativo de um momento histórico, de uma cultura e dos discursos que aí circulam. Nesse aspecto, apoio-me, interdisciplinarmente, nos pressupostos da micro-história, na qual expoentes como Ginzburg (1998) partem do estudo de vidas singulares como pistas para tecer um quadro histórico da sociedade de uma época.

4.1. Análise fina do relato de Tânia. “... uma experiência quase mística, como se eu pudesse, de alguma maneira conhecer uma deusa, sabe?".

Começamos pela análise do relato de Tânia, que, como já mencionado, foi amplamente divulgado em lista de discussão sobre gestação e em blogs relacionados ao tema, com publicação, no dia 31 de maio de 2013, no blog que a própria autora assina. Portanto, não se trata de um texto gerado para esta pesquisa especificamente, como foi o relato de Ivana, autora da epígrafe acima, mas, sim, de um documento público coletado e incorporado à base material deste estudo. 
Seu relato original é definitivamente multimodial, ilustrado com muitas fotografias, com vídeos e hiperlinks que não considerarei: aqui só me atenho ao texto verbal do documento, que se inscreve no gênero postagem de blog pessoal. Reconheço que o gênero - materializado no texto que nos serve aqui de objeto - inclui um aparato imagético que é relevante a seu funcionamento, mas optei por não analisar as imagens aqui, não por desconsideração de sua relevância, mas por querer focar especificamente numa análise minuciosa do texto verbal integral.

Feita essa introdução, passemos à análise. A primeira parte do texto foi reservada a um título escrito com fontes negritadas e, praticamente, duas vezes maiores que as fontes do corpo da postagem que se segue -, logo abaixo do qual aparece a assinatura de sua autora e o que chamei Sumário: uma estrutura macro das quatro partes em que a autora entende a divisão de seu relato. Reproduzimos esse movimento retórico ${ }^{21}$ no excerto (34) a seguir:
1) pré-gravidez
2) a gravidez
3) o parto
4) o pós-parto

Meu parto Orgásmico

Postado em maio 31, 2013 por Tânia Nguyen

Este relato é dividido e 4 partes:

O título da postagem, "Meu parto Orgásmico", constrói-se em referência intertextual ao filme documentário "Orgasmic birth: best-kept secret", lançado em 2008 e divulgado internacionalmente, no qual sete mulheres e seus companheiros, alternando-se a comentários de especialistas, expõem sua intimidade e buscam promover a possibilidade de que o evento parto seja associado a prazer, desconstruindo o discurso de que parto diz respeito somente a dor e sofrimento. Esse primeiro movimento do texto pode ser considerado criativo em relação ao potencial genérico que realiza, já que postagens em blogs dificilmente apresentam um sumário junto ao título. Isso pode indicar um esforço de didatização por parte da autora.

O segundo excerto do relato, a seguir em (35), apresenta uma 'pré-história' ou, como a autora o classificou em seu sumário, a história da "pré-gravidez", por se tratar não especificamente do parto relatado em primeiro plano, mas sim da gestação e do nascimento da primeira filha da autora, então com seis anos de idade. Em termos autobiográficos, ressaltamos a estratégia de

\footnotetext{
${ }^{21}$ Fazendo referência a Miller (1994) e a Swales (1990), Ramalho \& Resende (2011, p. 127) explicam que movimentos retóricos são "movimentos discursivos, com um propósito particular pontual, que servem aos propósitos globais do gênero e que se distribuem de maneira não sequencial e não obrigatória".
} 
identificação e verossimilhança, realizada pela autorreferenciação em "minha história" e na datação histórica dessa mesma história, "centrada no sujeito que a cria” (Alberti, 1991, p. 8).

\begin{abstract}
Minha história começa há seis anos atrás, quando eu engravidei da Nina. Eu sempre quis ter um parto normal, pois sei como é uma cirurgia e a cesárea está entre uma das mais invasivas que existem. Não é bonito, é uma cirurgia, e a meu ver, sempre era usada em emergências e quando era opção da parturiente. Busquei um G.O. que fizesse parto normal e acreditei. Acreditei que todos os procedimentos e instruções eram para que tudo desse certo, que me levasse ao meu parto. Mas não tinha ideia do quão enganada eu estava. Por ter essa confiança nele, sequer procurei outras pessoas, afinal, ele era "O" médico todo fofo, atencioso... eu nem desconfiava que existisse um movimento pela humanização do parto, que existia a tal "violência obstétrica", ou mesmo que ele pudesse, de fato, estar mentindo pra mim em algum momento. Gente, para e pensa: ele mentir seria algo antiético, certo? Enfim. Leiam o relato aqui (detalhe que na época em que a escrevi eu estava no começo do despertar, nem desconfiava que minha cesárea tivesse sido desnecessária).
\end{abstract}

Nesse excerto (35), em que a autora opta por começar a história seis anos antes do parto em questão, ela dá início ao processo explícito e voluntário de autoidentificação, ao dizer, de certa forma, que esta que escreve é uma mulher que queria parir desde a sua primeira gestação, e o intensificador "sempre" reforça, nos termos tanto de Martin \& White (2005) quanto de Laura Pardo (2011), essa vontade parir. Martin \& White (2005, p. 20), como já foi dito, mencionam três tipos de realização prosódica que poderiam ser úteis na interpretação das maneiras como elementos avaliativos podem operar de modo cumulativo, e um deles seria a intensificação, um tipo de realização que "envolve amplificação; o volume é elevado de tal maneira que a prosódia reverbera através do discurso [texto] à volta. Intensificação envolve repetição de vários tipos e é similar ao uso de movimento de volume e de tom para dar realce na fonologia (conforme observado por Poynton 1984, 1985, 1996)" (acréscimo meu). No relato de Tânia, é notável também a avaliação da cesárea, que, conforme a imagem que fazia à época, "sempre era usada em emergências", por não ser "bonita", por ser "uma cirurgia" "das mais invasivas que existem". A autora, então, levanta o pressuposto de que essa intervenção seja algo indesejável, salvo em situações emergenciais ou quando é opção "da parturiente". Ao selecionar esse e não outro termo para mencionar a mulher que está parindo, a autora se autoidentifica como alguém que está inserida no discurso sobre o parto e o nascimento e que conhece termos especializados referentes a essa prática social.

Entretanto, essa identificação com a especialidade do campo discursivo do parto é desconstruída para o passado, numa típica disjunção autobiográfica entre o eu narrador e o eu narrado, numa discrepância entre um antes e um depois, geralmente marcada por um evento 
divisor de águas, neste caso, o parto e/ou o conhecimento, o esclarecimento sobre a violência obstétrica: “um despertar”. Nesse passado, Tânia se identifica como ingênua ou incauta, incapaz de desconfiar da sinceridade de seu "médico todo fofo", desconhecedora da "tal violência obstétrica" - note-se aqui a estratégia de distanciamento do médico pelo uso de "tal" e pela ironia em "todo". Àquela altura, teria buscado "G.O. que fizesse parto normal” e acreditado. A opção limitada a uma formação profissional (ginecologista obstetra) e a seleção da lexia "fazer parto" (e não aparar o bebê, por exemplo) deixam ver o discurso internalizado acerca do parto que ainda associa o protagonismo e a agência nessa prática social a uma pessoa formada em medicina. Ao repetir duas vezes "acreditei", a autora intensifica a imagem da mulher que confia na autoridade e competência que um/a G.O. deveria representar no caminho que a levaria a seu parto.

O conectivo adversativo "mas" introduz a oração seguinte numa extensão ${ }^{22}$ constitutiva de um deslocamento, intensificado pelo "quão" que pré-modifica "enganada”. A seguir, Tânia identifica o profissional que a atendia como "O [maiúsculo!] médico todo fofo, atencioso". Aqui, pode-se entrever no interdiscurso uma referência ao 'cesarista fofo', já que entre ativistas contra a violência obstétrica é recorrente a menção ao ginecologista obstetra 'fofo', aquele que é 'muito bonzinho', atencioso e pró parto natural até o dia em que a cesárea se torna "emergencial", na maioria das vezes pela suposta incapacidade da mulher (Regis \& Resende, 2015, p. 589).

Na sequência, a autora segue sua autoidentificação como alguém que não só não conhecia, mas "nem desconfiava" da existência de um movimento pela humanização do nascimento ou da “tal” violência obstétrica. Esse marcador, "tal”, reforça, intensifica a noção de desconhecimento do que parece ser, no momento de redação do relato, algo óbvio para a autora - mas que, diríamos nós, continua sendo algo muito distante para grande maioria das mulheres. Esse movimento entre confiança ("acreditei”, "Acreditei”, "essa confiança nele", "eu nem desconfiava") e engano (“o quão enganada eu estava”, "estar mentindo") é a força argumentativa que constrói essa primeira parte do texto. A essa altura, acontece a primeira interpelação ao/à leitor/a. com "Gente, para e pensa", a autora convida suas/seus interlocutoras/es a uma reflexão sobre a expectativa de ética nas atitudes médicas, antes de utilizar-se da metáfora do "despertar", semelhante ao momento da conversão agostiniana, para

22 "Na extensão, uma oração expande o significado de outra introduzindo algo novo por meio de adição, deslocamento ou alternativa ('e', 'ou', 'mas').” (Halliday, 2004 apud Ramalho \& Resende, 2011, p. 123) 
referir sua tomada de consciência no que se refere ao cenário de violência obstétrica sistêmica que vivemos neste início de século no Brasil.

No campo dos discursos sobre o parto, há uma disputa discursiva sobre a palavra "parto", sobre essa denominação ser adequada também para se referir a uma cesárea ou não. Embora no excerto (36), a seguir, a autora chame de parto sua cesárea, ela não considera ter com ele, literalmente, dado à luz.

(36) Depois de um tempo, eu e meu marido cogitamos a ideia de ter outro filho, a Nina já estava com 5 anos e estávamos numa fase muito tranquila e de segurança. Aos poucos fui conversando com a Dani V., que eu sempre via postando material relacionado ao parto e afins. Nós estudamos juntas quando pequenas mas não éramos amigas, só colegas, o facebook com suas ligações malucas nos reaproximou e foi lindo $=$ ).

Voltando, eu fui metralhando ela de perguntas, abri a portinha do universo do parto humanizado, do parto domiciliar (que até então eu tinha aquela ideia manjada que, pra ter em casa, precisava ser milionária, ter ambulância na porta e equipe com GO, neonatologista, enfermeiras e tals), e vi meu primeiro parto: [link para um vídeo] ${ }^{23}$ que marcou muito. Me fez chorar, me fez pensar. E ainda ouvi dela: Ta, você pode ter o parto dos teus sonhos. Me imaginei em casa, com a amoreira do meu jardim ao fundo, pessoas amadas ao meu redor e aquele momento de, literalmente, DAR A LUZ.

Esse excerto (36), que dá início à segunda subdivisão de seu relato, começa mencionando a influência de novas possibilidades de comunicação, como as redes sociais virtuais, nesse processo emancipatório em busca do "parto dos sonhos". O trecho apresenta nova metáfora ("portinha do universo do parto humanizado"), referindo-se ainda ao "despertar", do excerto anterior, e ao sistema de informações que estava por conhecer, revendo mitos também sobre o parto domiciliar, como a necessidade de uma estrutura opulenta e, portanto, inacessível à maioria das mulheres. No excerto seguinte, a autora especifica em mais detalhes o "universo" a que chegou por abrir essa "portinha":

(37) Em dois meses eu engravidei e comecei a buscar as opções da cidade, entrei em grupos do face relacionados ao assunto, vi muitos vídeos de parto e li muito sobre cada dúvida que surgia. Fui desmistificando tudo que pudesse ter relação com o parto. E olha, descobri um universo. Desde coisas maravilhosas como entender o nosso corpo e como ele age de forma perfeita, até ouvir relatos pavorosos de violência obstétrica, de mentiras deslavadas para levar a mulher (mesmo aquela que quer o parto normal) para a cesárea. Fui para Brasília conhecer os grupos de parto humanizado, a Dani, e tudo mais relacionado, me lembro da emoção de conhecer a Isis e ela me contar que teve

23 O vídeo articulado a este texto por meio de hiperlink está disponível no site YouTube, em <https://www.youtube.com/watch?v=nOBhIC55kEA>. Consultado em 17 de julho de 2015. 
os dois filhos em casa! Na minha cabeça era algo como "puxa, "elas" (elas = mulheres que pariram em casa) existem mesmo" (uma experiência quase mística, como se eu pudesse, de alguma maneira conhecer uma deusa, sabe?). E também tomei conhecimento que a cidade onde moro (S.J. Rio Preto, SP) é uma das que tem o maior índice de cesáreas... do Brasil. Tem até professor de faculdade dizendo que a cesárea é melhor em todo os aspectos pra o nascimento (melhor pra quem, eu pergunto).

Nesse excerto (37), a autora menciona mais uma vez a importância das redes sociais e reforça com os intensificadores "muitos" e "muito" a sua busca por informações. Seleciona o verbo “desmistificar", deixando pressuposta a acusação de que, em atenção obstétrica, as "verdades" não se baseiam em leis naturais ou físicas, mas em mitos sem evidências práticas ou científicas. E repete, intensificando mais uma vez, a metáfora da descoberta de um universo, do universo de (in)verdades sobre o parto. Avalia os achados como "coisas maravilhosas", "relatos pavorosos" e "mentiras deslavadas". Interessante observar que, apesar do uso de 'desmistificar', a autora descreve a experiência de conhecer uma mulher que pariu em casa como sendo uma experiência "quase mística" e, com elemento coesivo "como se", ela elabora, com pretérito imperfeito do subjuntivo, a possibilidade de estar conhecendo "uma deusa", uma figura portanto sobrenatural. E, de golpe, volta ao mundo do natural, do científico, trazendo dados estatísticos sobre o índice de cesáreas de sua cidade, $80,1 \%$ (conforme o gráfico que acompanha o texto verbal em tela), ao mesmo tempo em que questiona as autoridades representantes desse campo do conhecimento, como o "professor de faculdade", um técnico que, supostamente, deveria trabalhar com evidências científicas.

Diante disso, surge, no excerto (38), a resistência a se dirigir a uma instituição cuja dinâmica é o motor que mantém índices cirúrgicos tão elevados:

$$
\begin{aligned}
& \text { Enfim, ir para o hospital não se tornou uma opção, era praticamente certeza } \\
& \text { que, chegando lá, me encaminhariam para a césa. Ou eu teria que chegar com } \\
& \text { o neném saindo. Sem falar que, com muita, mas muita sorte eu encontraria } \\
& \text { uma equipe humanizada num plantão e mesmo assim as probabilidades de eu } \\
& \text { passar por várias intervenções (mesmo num parto normal) era praticamente de } \\
& 100 \% \text {. Sem falar que, não sei você, mas eu tenho pavor de hospital, pra mim } \\
& \text { é um local de doenças, pessoas estranhas (e muitas vezes arredias), agulhas, } \\
& \text { álcool, frio, macas duras... ainda mais no SUS. Não iria pro hospital sem } \\
& \text { necessidade, só isso. }
\end{aligned}
$$

Concluindo com "enfim", a autora sustenta uma visão sobre o parto, não como evento hospitalar sui generis, mas como um evento que poderia se tornar hospitalar: ao dizer "não se tornou", em lugar de, por exemplo, “deixou de ser uma opção", ela evidencia essa ideia. Então se utiliza mais uma vez da repetição "muita”, "muita”, ao citar quanta sorte seria necessária para se 
deparar, por acaso, como uma "equipe humanizada". Entretanto, o elemento coesivo "mesmo assim" insere uma extensão, nos termos de Halliday (2004 apud Ramalho \& Resende, 2011, p. 123), um deslocamento desse estado de sorte para os, ainda que modalizados, "100\%" de probabilidade de ser submetida a "várias intervenções". O excerto é finalizado com uma avaliação negativa explícita da instituição hospitalar, da qual ela afirma ter "pavor", em um trecho que ganha reforço na interpelação da/o interlocutor/a ("Sem falar que, não sei você, mas eu tenho pavor de hospital").

No excerto (39), a seguir, a autora retoma o relato do parto em tela, focalizando uma gestação "biologicamente perfeita" e aquilo que chama de "terrorismo" da "GO do postinho":

(39) Voltando, minha gravidez foi fisiológica e biologicamente perfeita, não tive nenhum problema, nem sustos, nada. E mesmo assim, toda vez que eu comentava com a GO do postinho algo sobre parto normal ela falava da cesárea anterior, ou que era muito cedo pra pensar nisso, ou que eu devia parar de ter esperanças em relação a isso e pensar em coisas mais "importantes", pediu o último ultrassom dizendo: -ah, você quer parto normal? Vamos pedir o ultrassom só pra ver se ta tudo certinho pra isso, de repente né? (e, de fato, estava... nenhuma lenda urbana foi detectada, como circular de cordão ou bebê sentado ou placenta "velha" (eu poderia fazer uma lista engraçadíssima pra vocês de desculpas para césa vistas num ultrassom ou sem nada, aliás, vejam por si mesmos:

http://estudamelania.blogspot.com.br/2012/08/indicacoes-reais-e-ficticiasde.html)

O mais incrível é que essa GO, mesmo que eu quisesse, não teria nada a ver com o parto, ela só faz o pré-natal, e eu me pergunto: -pra quê fazer esse terrorismo se ela sequer vai estar ou ganhar nada com o parto? Eu vejo esse discurso (e vários outros) relacionados a um terrorismo da ideia do parto normal sendo feito não só pelos profissionais "interessados" na cesárea, mas também pela mídia, por grandes meios de comunicação, por pessoas que reproduzem a fala do "sistema" e nunca se questionaram acerca dos fatos na história... enfim, tem muita lenda nessa área, muitos segredos que só ajudam aqueles que não vão passar por um parto. Porque, depois que você passa, você entende do que estou falando. Entender que tive que passar por uma cirurgia tão grande, com proporções psicológicas, de maneira desnecessária, sem respeito algum pelas minhas escolhas e vontades, pelas minhas peculiaridades culturais e pessoais, dói. E muito.

A autora marca sua retomada do tema no início do excerto, com "Voltando", e em seguida avalia positivamente sua gestação "fisiológica e biologicamente perfeita", e intensifica a negação, "não", "nenhum”, "nem”, "nada”, de qualquer problema nesse período. Mas em seguida, mais uma vez pelo uso do marcador de coesão "mesmo assim", evoca um deslocamento marcado pelo intensificador "toda", demonstrando como, mesmo em face da maior perfeição, uma gestante pode se deparar com uma série de 'senões', marcados no excerto 
pelos elementos coesivos de alternância, "ou", "ou”, que demonstram pouca abertura quando uma gestante fala em parir naturalmente, em especial quando ela tem uma cesárea prévia no histórico. Com relação ao último pedido de ultrassonografia, a interjeição "ah" deixa pressuposta a surpresa da GO diante do desejo de parir, denotando diferença ou desvio nessa atitude. E a modalidade caracterizada por “de repente, né?" levanta o pressuposto de que existiria, sim, essa possibilidade, contudo ela não seria o ponto de partida das considerações. Ainda sobre esse "né?", podemos reconhecê-lo como uma estratégica vinculação e motivação da solidariedade por parte da leitora provável, interpelada a se identificar e a se juntar à crítica exposta. Crítica à variada gama de "lendas urbanas", ou falsas indicações para uma cesárea, cuja elaboração se insere pelo marcador "como" e se desdobra pelas conjunções "ou”, repetidas quatro vezes na primeira parte do excerto, elaborando e explicitando o caráter lendário de certas justificativas para cesarianas. Ao mencionar essa assunção, a autora se utiliza de argumento de autoridade, assinalado pela menção ao texto (articulado por hiperlink) sobre indicações para cesárea, reais e fictícias, publicado pela médica, professora e pesquisadora Melania Amorim em seu blog de divulgação de medicina obstétrica baseada em evidências científicas.

No segundo parágrafo do excerto (39), a autora tece uma consideração central na busca por pistas que nos levem a uma melhor compreensão do problema social da assistência obstétrica brasileira, falha e deficiente. Sua consideração nos ajuda a ampliar a visão, diminuindo o risco de encararmos o problema como sendo uma questão de ética pessoal e de cunho individual, possivelmente focada somente em ganhos ou lucros pessoais. Ela nos instiga a pensar a questão como algo sistêmico, como algo situado num âmbito discursivo estrutural que precede e baliza a prática individual. Ao qualificar o posicionamento da GO como "mais incrível ainda", mitificando o peso de sua atuação "só" fazendo o pré-natal, a autora do relato nos conduz à questão do que ela denomina "terrorismo da ideia do parto normal", um discurso reproduzido e disseminado irrefletida e sistemicamente, inclusive nos meios de comunicação, que acabam favorecendo a cultura cesarista. Pereira, Franco \& Baldin (2011, p. 385), em seu estudo sobre a dor e o protagonismo da mulher na parturição também tratam desse aspecto:

Alguns relatos apontam para a influência da mídia na construção ou nos reforços simbólicos do medo da dor no parto normal e na facilidade e segurança do parto cesáreo. Questionada sobre a influência da mídia, a entrevistada afirma: "Acho que influencia sim, porque, no parto normal, se você for ver, até nos filmes aparece a mulher sofrendo, toda suada, berrando, fazendo escândalo no hospital. E numa cesárea não, se você for assistir à novela, a mulher está ali deitada, aparece sorrindo, conversando com o marido e a criança no colo, como se tudo tivesse corrido perfeito e que não houvesse 
risco algum" (F. S., 29 anos).

O "terrorismo" mencionado no texto é uma metáfora significativa, intra e extratextualmente. A seleção lexical reforça a construção social do medo do parto, realizada por meio do discurso médico. Ao mesmo tempo em que remete a um termo muito em voga nas sociedades ocidentais deste início de século. Em se falando de "terrorismo", e considerando-se que vivemos uma época de intensa construção discursiva do terrorismo, o que não acontece dissociado da promoção do medo como sentimento cotidiano, vale lembrar o argumento de Bauman (2008, p. 31), quando afirma que todos os dias é ampliado um "inventário de perigos", sempre com alguma novidade diante da qual precisaríamos nos acautelar. Entretanto, a quantidade de perigos postulados seria muito inferior à daqueles com potencial para se concretizar de fato, de forma que sempre poderíamos "esperar que este ou aquele desastre recentemente anunciado acabe nos ignorando".

Voltando ao excerto (39) do relato de Tânia, em seguida a autora serve-se mais uma vez do item lexical "lenda", reforçado pelo marcador "muita", e da palavra "segredos", também "muitos", delineando um pouco mais da imagem que vem construindo em seu texto de um misticismo que embasaria a prática da assistência obstétrica no Brasil, para a qual não há, em muitos aspectos, um respaldo baseado em evidências científicas, embora para o senso comum a medicina seja uma prática respaldada cientificamente. Diante dessa constatação, ela volta a focar em si mesma, e em sua cesárea prévia, como uma mulher operada desnecessária e desrespeitosamente, em quem esse fato ainda "dói. E muito". Atente-se que esse misticismo não é atribuído à prática das parteiras, como poderia corresponder ao discurso hegemônico, mas à medicina obstétrica acadêmica.

No excerto em (40), a seguir, já nas linhas introdutórias, há mudanças, até na seleção lexical, que ensejam essa alteração de perspectiva relacionada ao lugar e à assistência adequada para o evento parto:

(40) Fui atrás de parteira, GO ou Enf. Obstetra que pudesse acompanhar meu parto, mesmo que fosse para vir de outra cidade. E tava bem complicado, as semanas iam passando, o parto se tornando próximo e nada... Quando encontrava alguém essa pessoa não poderia vir, ou teria parto na mesma época, ou só se eu fosse pra tal cidade... e eu querendo ter meu parto aqui, na minha casa mesmo. Me senti mal, pensei em alternativas malucas como ir pro hospital com o bebê saindo, ou ter em casa só com meu marido, mas não queria de maneira alguma colocar a minha ou a saúde do bebê em risco. Não desisti e continuei procurando. Não adianta também você chamar alguém só por essa pessoa "poder" fazer o teu parto, você tem que se sentir segura, amparada e 
ter certeza que o profissional é qualificado para um parto.

A ideia de um parto assistido é exatamente o que a palavra diz, você e seu filho serem assistidos em tudo durante o parto. E, para quem tem dúvidas, ele é qualificado tanto para pequenas emergências quanto para saber que aquela situação pede uma transferência para um hospital. E esse tempo é o mesmo utilizado para uma emergência hospitalar. Selecionei dois ótimos artigos para quem sabe pouco sobre o tal parto domiciliar:

Alguns mitos sobre o parto domiciliar

Um novo olhar sobre o nascimento: o parto domiciliar ${ }^{24}$

Em contraste com o que encontramos na passagem referente ao período pré-natal anterior, nesta altura a autora já não busca “um G.O.” que ‘faça seu parto', mas sim vai “atrás de parteira, GO ou Enf.[ermeira/o] Obstetra" para "acompanhar" seu parto. Neste fragmento discursivo, lemos a ponta de um iceberg de mudança de perspectiva. Além da menção a outros/as profissionais entre suas alternativas, vemos inclusive a parteira em primeiro lugar. E de nenhum/a dessas/es profissionais ela espera protagonismo, ninguém deverá 'fazer o parto', mas tão somente acompanhá-lo. Quando usa aqui essa expressão, a traz antecedida pelo verbo modal "poder", entre aspas, num período introduzido por "Não adianta", necessário seria um/a profissional “qualificado para um parto", sem o "fazer" antes do parto. Embora trate-se de uma sutileza, não pode-se desconsiderar a mudança de perspectiva. E é essa disposição, ou expectativa, que a autora avalia expressamente no segundo período do excerto, logo em seguida, se utilizando do elemento de reforço "bem" antes do qualificador "complicado". Adiante mais uma sequência de conjunções alternativas "ou", novamente utilizadas para citar as diversas dificuldades, desta vez não fisiológicas, mas que poderiam ser a pedra no caminho para o parto desejado. Nesse começo de excerto, fala sobre o contexto e o avalia, "bem complicado", volta a falar sobre o contexto, "Quando encontrava alguém... minha casa mesmo" e se avalia: "me senti mal”, "não desisti e continuei procurando". Nessa autoidentificação configura-se o que Castells (1999) chama identidade de resistência. Resistência cuja abonação acontece textualmente no oitavo excerto, a seguir.

Eis que, lá pela 35 semana, eu consegui uma indicação pela doula Ana J. (de Ribeirão Preto, SP) de uma enf. obst. de São Paulo-capital que costumava viajar para fazer partos. A Carla L. Ao falar com ela tive uma baita surpresa pois ela estaria em Rio Preto em 3 dias por conta de uma consulta de outra grávida que (pasmem!) também teria um parto domiciliar em São José do Rio Preto. Eu cheguei a dar gritinhos histéricos de felicidades e achei que ela estava brincando comigo. E não estava. Implorei por uma consulta no mesmo

24 Os textos articulados aqui por hiperlink estão disponíveis, respectivamente, em <http://bibliografiadadoula.wordpress.com/2013/04/10/alguns-mitos-sobre-o-parto-em-casa/> e em <http://bibliografiadadoula.wordpress.com/2013/01/07/um-novo-olhar-para-o-nascimento-o-parto-domiciliar/>. 
dia e deu tudo certo. Ela veio, conversamos, nos entendemos e deixamos tudo claro: -valores, vontades, como faríamos no dia... enfim. Quando eu chegasse perto das 40 semanas, nós nos comunicaríamos todo dia para saber de sinais do parto e, assim que ela achasse necessário, viria pra cá de carro. E assim, os últimos dias foram seguindo, com aquele inchaço básico de fim de gravidez, com faltas de ar pelo bebê já estar enorme, com noites mal dormidas...

E eu tentando não ficar ansiosa, via vídeos de partos lindos, pensava na minha cesárea, na ansiedade do parto da Nina... e sentia ainda fresquinha a dor da cesárea. E sabia, que essa cicatriz só pararia de doer na próxima etapa: o parto.

O excerto (41) inicia-se com "Eis que", fórmula recorrente, por exemplo em textos bíblicos, que denota um acontecimento de alguma maneira inesperado ou extraordinário, e que aqui introduz na narrativa a chegada de "uma enf.[ermeira] obst.[etra] de São Paulo-capital que costumava viajar para fazer partos", evento que, de forma coerente com a escolha estrutural que inicia o excerto, classifica-se como "uma baita surpresa". Em contraposição ao discurso hegemônico pró cesariana, Tânia traz a seu relato a figura salvadora da enfermeira obstetra. E com essa aparição vem também a possibilidade de 'cura' da "ainda fresquinha dor da cesárea", que "só pararia de doer" com o parto. Aqui, ainda que sutilmente, a autora contrapõe "cesárea" e "parto", e nos leva a pensar na disputa discursiva que ocorre também pela apropriação de conceitos, encerrando-lhes certas possibilidades, o que neste caso equivaleria a excluir a cesárea das possibilidades atribuídas ao parto, que poderia ser natural, domiciliar, vaginal, hospitalar, humanizado, desassistido, mas não cesáreo, como por vezes se ouve/lê.

No próximo excerto, (42), desenvolve-se o relato, sobretudo, da parte inicial do parto. Não me aterei analiticamente à passagem inicial, por considerá-la um excurso dentro do relato cuja análise fina não traria muitas contribuições para as questões em pauta. Mas mantenho-a aqui para ter o relato na íntegra, de forma a permitir às/aos leitoras/es o conhecimento completo do texto em foco. A passagem que se segue ao primeiro parágrafo, contudo, será sim analisada por representar vários enunciados já aludidos na análise estrutural, além de algumas questões novas.

(42) A ideia inicial era a de que, se eu tivesse algum sinal (na verdade, eu tava quase contando sobre tudo) eu falaria com a Carla (por tel, face, mensagem) e ela viria pra cá assim que achasse necessário. Também estava contando com a Carol Lua, amiga de longa data, também enfermeira obstetra, que, na dúvida, viria me ver para que não acontecesse nenhum imprevisto ou que, pelo menos, diminuísse minha ansiedade. Mas, não aconteceu nada conforme o esperado, foi melhor. A Carla veio pra Rio Preto antes por conta da outra grávida (a Ava), que estava com a bolsa rota e aproveitou para me examinar na quinta, depois voltou pra casa da Ava. E o pequeno Enzo nasceu! Depois do parto da Ava, que foi lindo, ela voltou a minha casa e percebeu que meu colo do útero já estava diferente, mais fino, dilatado, e eu ainda sem dores. Ela ficou na dúvida... pensou em ir pra SP no domingo de manhã, mas depois de me examinar novamente, achou mais prudente ficar. Afinal, ela já havia perdido 
o aniversário do marido (que foi no sábado dia 11) e, pelo jeito, perderia o dia das mães também.

Ficou. Eu em nítidos pródromos quase indo pro TP ativo mesmo, mas sem dores, sem muitos desconfortos. Ela até me fez um chá, que ajuda a entrar em TP. A Carol também veio me ver e aos poucos eu fui achando que, puxa...acho que tá começando.

Na segunda feira, por conta de um exame de toque (pois era só assim que elas podiam saber como estava o meu TP (Trabalho de Parto), por eu não sentir dores, elas me relataram que a bolsa de líquido amniótico estava muito rente à cabeça do bebê, (e esta bem encaixadinha e baixa) e que, isso poderia ser um sinal de mecônio. Daria pra ver o líquido através de um exame, mas, por conta da bolsa tão grudadinha a cabeça dele, tava impossível ver qualquer coisa. Resolvemos esperar. No fim do dia, por receio de mecônio (e se fosse, eu seria transferida pro hospital para não haver risco de aspiração de mecônio), elas resolveram verificar novamente, e nada havia mudado. Tentamos desencaixar um pouco o bebê para tentar ver o líquido, mas nada. E, em conjunto, lá pelas $2 \mathrm{~h}-3 \mathrm{~h}$ da madrugada de segunda pra terça, achamos mais seguro estourar a bolsa para verificar o liquido ao invés de ficar com receio do mecônio. Foi o primeiro momento durante o parto que eu tive que enfrentar meus mais terríveis pensamentos, que tive que me manter firme que aquilo era o melhor e mais seguro para mim e pro bebê, e que, se fosse necessário, iria pro hospital. Me mantive firme e forte, segura da minha equipe e da minha escolha. E elas fizeram o procedimento. Resultado? Líquido limpinho, perfeito, clarinho. Ou seja, nada de mecônio!

Mais uma vez está representado o processo de autoidentificação de Tânia enquanto conhecedora de termos especializados do discurso sobre o parto, marcado por sua seleção lexical igualmente especializada em "pródromos" e "TP ativo". "Pródromos" corresponderiam à etapa imediatamente anterior ao início do TP (trabalho de parto), cuja fase inicial ainda não é considerada "TP ativo", este relacionado a uma frequência e intensidade maiores na contração e a uma dilatação avançada do colo do útero, uma segunda etapa do TP.

Ao mencionar a atitude da enfermeira obstétrica Carla, que "até" lhe "fez um chá", seguido da oração explicativa "que ajuda a entrar em TP”, Tânia deixa indícios que permite alguns comentários. A necessidade de um chá para que o corpo entre em trabalho de parto, embora seja uma alternativa caseira, não deixa de se alinhar a um discurso no qual é vigente a já mencionada "visão pessimista do corpo feminino", cuja fisiologia falha justificaria toda a sorte de intervenções, mais ou menos invasivas, para garantir o êxito do nascimento. Mas como diz um ditado alemão sobre o cuidado, "jede Anwendung ist auch eine Zuwendung” - toda aplicação (tratamento), é também uma atenção - e uma atenção, é já um acolhimento. E essa atenção, esse acolhimento, podem se concretizar na oferta de um chá, que, se não provoca o início do TP, nem descontrói o discurso sobre a fisiologia falha, pode sim ser constitutivo da antes citada "rede permeada pela subjetividade", característica da atuação das parteiras tradicionais (Maturana \& Zöller, 2004, p. 140 apud Borges, Pinho \& Santos, 2009, p. 378) e 
que, apesar de desconsiderada pela ciência hegemônica, fomenta afetos e vínculos "que no processo parturitivo são potencialmente terapêuticos".

Outro indício de que a prática de assistência representada no relato de Tânia, também se alinha, ainda que parcialmente, com o discurso intervencionista, ainda que, de certa forma, também deixe transparecer a inconformidade de Tânia diante de uma intervenção d e sua equipe, um “exame de toque", "pois era só assim que elas podiam saber como estava o meu TP”, é a necessidade de justificar essa ação. Justificativa essa que está texturizada na oração explicativa iniciada pela conjunção explicativa "pois", que estabelece mais uma relação lógico-semântica de expansão com realce. A necessidade de explicar, justificar, a adequação do exame pode ser interpretada como a percepção da autora de alinhamento com a prática médica hospitalar, visto que, como afirmam Crizostomo, Nery e Luz (2007, p. 103), num estudo que fala sobre a vivência de mulheres em partos domiciliares e hospitalares, as mulheres que optaram pelo parto domiciliar o fizeram por várias razões, entre elas constando "a não-realização do toque vaginal", pois, segundo elas, no hospital "o parto era mais demorado, realizavam muitos toques que as deixavam machucadas".

Um alinhamento com o discurso intervencionista também é indicado pelo pressuposto envolvido na afirmativa "poderia ser um sinal de mecônio". Embora não haja expressão verbal do termo "sofrimento fetal", há sim a relação lógica pressuposta, por ser amplamente divulgada no senso comum, entre a presença de mecônio - a primeira excreção fetal - na bolsa amniótica e o chamado, e temido, sofrimento fetal - expressão que geralmente constitui as mulheres subjetivamente como propensas a se submeter, sem questionamentos, a qualquer procedimento sugerido pelo pessoal da assistência, inclusive a uma cirurgia cesariana, embora o mecônio em si, desacompanhado de batimentos cardíacos fetais com padrão anômalo, não configure justificativa para tal procedimento (Amorim, 2012). Com relação a essa situação, a médica e pesquisadora Melania Amorim disserta num artigo publicado pela EBC em 2015:

Concluímos, portanto, que o fundamental é distinguir se o bebê se encontra ou não em sofrimento. A ausculta dos batimentos cardíacos fetais (BCF) continua sendo a forma não-invasiva mais eficiente de se monitorizar o bemestar fetal, podendo ser realizada de forma intermitente (com o sonar Doppler) ou contínua (pela cardiotocografia). Uma boa ausculta fetal durante o trabalho de parto é tranquilizadora. Se há alteração dos batimentos e a freqüência cardíaca fetal assume um padrão "não-tranquilizador", está indicada a antecipação do parto, que pode ser por cesariana ou, se o evento ocorre no período expulsivo, através de fórceps ou vácuo-extração. 
A inconformidade presumida de Tânia também pode ser deduzida quando, ainda sobre esse tema, damos um salto e analisamos o segundo parágrafo, do excerto em (43), a seguir. Esse segundo parágrafo do excerto em (43) é iniciado com um verbo modal, "tenho", que engendra uma modalidade deôntica (Fairclough, 2003, p. 172) pela qual se estabelece a obrigação categórica em relatar mais esse aspecto do seu parto. O incômodo sentido durante o toque é representado numa relação causal segundo a qual o "colo posterior", ou seja, seu corpo é responsabilizado. Uma alternativa a essa representação seria a atribuição da causa do incômodo à ação da enfermeira, visto que há quem afirme que o exame de toque não precise ser dolorido. No último período do parágrafo, Tânia avalia explicitamente esse momento e, com uma expressão idiomática coloquial, em voga na época em que escreveu o relato, "pronto, falei”, denota seu incômodo, ou mesmo dificuldade, em admitir que, mesmo em seu parto domiciliar, possa ter sido vítima de intervenções desnecessárias, como toques repetidos e doloridos e o rompimento mecânico da bolsa amniótica.

Mas anter de reproduzir o excerto em (43), sigamos com a análise do excerto em (42), gostaria de mencionar a questão do medo, já problematizada na análise estrutural e presente também neste relato, embora Tânia não selecione exatamente a lexia "medo", mas sim lexias sinônimas, como "receio" ou "terríveis pensamentos", "receio" por parte da equipe e receio de sua parte. "Receio" que justificou a intervenção consentida, como se deduz pelo verbo "achar" conjugado na primeira pessoa do plural, "achamos", denotando a decisão compartilhada entre assistentes e mulher, todas em busca do "mais seguro". A essa altura o relato tem um ponto de inflexão retórica, texturizado pela expressão "foi o primeiro momento durante o parto" em que ocorre algo que parece uma expectativa pressuposta para uma mulher em trabalho de parto, o momento do medo e da insegurança, medo do porvir, insegurança quanto às escolhas, e as necessidades daí decorrentes, inseridas no relato pela modalidade deôntica concretizada por meio do verbo “ter" na primeira pessoa do pretérito perfeito, "tive”, denotando uma obrigação ou necessidade imputada pelo momento e pelo medo, que ao fim e ao cabo se mostrou infundado, dado o “líquido limpinho, perfeito, clarinho. Ou seja, nada de mecônio!”. Nesta passagem, o uso dos diminutivos, "limpinho", "clarinho", ao lado do adjetivo "perfeito", texturiza um imagem romantizada da possibilidade de perfeição no parto, além de pressupor imperfeição do líquido amniótico escuro, por conter mecônio, reforçando assim o medo nutrido discursivamente de que a presença de mecônio seja sinal de sofrimento fetal, embora seja sabido que esse possa ser apenas uma comprovação de maturidade do feto, maturidade desejável no momento do nascimento. 
Tânia segue seu relato com o excerto em (43), em mais uma inflexão, inserida pela interjeição “Ah" e uma oração coordenada que constitui uma expansão por extensão, nos já mencionados termos de Halliday (2004 apud Resende \& Ramalho, 2011, p. 123), e, ao mesmo tempo, uma ampliação, uma intensificação marcada em "melhor", que envolve paralelamente uma elaboração, também nos termos de Halliday, do que vinha sendo relatado até ali, o início do trabalho de parto assistido em domicílio por uma enfermeira obstetra.

\begin{abstract}
Ah, e o melhor estava por vir, em uma ou duas horas, meu TP ativo começou! Eu comecei a sentir as tais contrações doloridas e pulamos todas de felicidade quando começou! Sim! Parece loucura, mas eu estava muito feliz com minhas dores. Era como se, durante esse tempo todo eu estivesse na fila para "aquela" montanha russa incrível, e agora, com as contrações e dores, eu tivesse acabado de embarcar no carrinho. Estava eufórica. Aliás, todas nós estávamos. Tenho que relatar também que, meu colo estava posterior (e se manteve assim por um longo tempo) o que fazia com que o exame de toque fosse bem incômodo e também, com que o TP demorasse. Essa foi a parte dolorida e chata do parto, pronto, falei.

Voltando. Nessa primeira parte, eu sentia as dores e estava bem consciente, me lembrava da famosa respiração "cheira flor, assopra vela", de vocalizar quando necessário (vocalizar aqui é emitir um som quase que gutural, mais grave, abrindo bem a boca, a faringe. Ajuda a relaxar e a dilatar o colo do útero, pois são sistemas que se conectam. Não confundir com gritos histéricos de dor), de tomar água, de comer...enfim. Em casa, o telefone foi desligado, o meu marido ainda foi fazer uma filmagem (acho que ele estava tão ansioso que conseguiu um pretexto para sair um pouco e voltar mais calmo), a minha filha em casa, duas amigas e duas enf. obstetras. Fomos visitados por um beijaflor, por velas de mel, por orações, por carinhos. Os cachorros nunca ficaram tão quietos e o dia se arrastou da maneira mais surreal do mundo.
\end{abstract}

O primeiro parágrafo desse excerto em (43) já foi comentado na análise estrutural, devido ao uso da metáfora do parque de diversão, uma estratégica contradiscursiva denormalizadora (M. Jäger, 1996) que produz uma nova possível relação entre a parturiente e as dores do parto, um incômodo que antecede o ápice do parir. No relato de Tânia, verifica-se mesmo um certo deboche diante da dor, assinalada pela referência às contrações pelo uso pronominal de "tais", em "as tais contrações doloridas". A autora do relato denota consciência e clareza de sua fala denormalizadora, pois marca a pressuposição da surpresa por parte das/os leitoras/es com a frase "Sim!" Seguida de uma expansão com elaboração que verbaliza a reação pressuposta, "parece loucura", seguida de uma expansão alternativa, cunhada pelo uso da conjunção adversativa "mas" seguida pela imagem metafórica do carrinho de montanha russa, brinquedo concorrido por muita gente num parque de diversões, mas também evitado por pessoas mais receosas, ambas as atitudes devido às sensações a ele associadas. No caso dessas sensações, mas também das sensações ou dores associadas às dores do parto, além do componente natural 
há também o elemento cultural envolvido, um aprendizado sobre essas sensações, o caráter histórico discursivo, como defendem Guerci \& Consigliere (1999) em sua Antropologia da dor.

Seguindo com a análise do excerto em (43), temos logo após o segundo parágrafo, já comentado, um marcador discursivo que, mais uma vez, denota uma avaliação da confissão concluída com "pronto, falei”, uma avaliação dessa confissão como algo fora do lugar, e que interrompe o fluxo desejado do relato. "Voltando" indica que no parágrafo anterior aprece algo que insiste em ser dito, mesmo quando isso não é desejável. No segundo período do parágrafo, quando Tânia afirma que "nessa primeira parte, [ela] sentia as dores e estava bem consciente, [...] lembrava da famosa respiração 'cheira flor, assopra vela', de vocalizar quando necessário", ela levanta um pressuposto de que haveria outra(s) parte, possivelmente, menos consciente(s) ou sem lembrar da "famosa respiração 'cheira flor, assopra vela"”. Note-se que embora haja, ao longo do relato, a representação de um retorno ao natural ou ao instintivo, nessa menção à respiração supostamente adequada, é reconhecido um lugar para o que Tornquist (2002, p. 489) chamou de "pedagogia do parto", decorrente do reconhecimento da necessidade de se ensinar a mulher a parir, também recorrente entre profissionais, ativistas e educadoras/es da humanização do parto, cujas vertentes, quando associadas apontariam "para a impossibilidade de pensar o parto como um evento além ou aquém da cultura" sendo "preciso, portanto, aprender a parir." Entretanto essa pedagogia corresponderia a encarar a mulher e seu corpo como lugar de saber e poder, "capazes de ter seus filhos com a mediação e apoio de outras mulheres, não lapidadas pela formação médica intervencionista” (Tornquist, 2002, p. 490). Embora a palavra parteira só seja mencionada uma vez em seu texto, nessa mesma página Tornquist o faz relembrando que "as mulheres [...] foram expropriadas de seus saberes, de seu trabalho como parteiras e dos poderes no campo da parturição", e isso me leva a afirmar, em consonância com Silvéria Santos ${ }^{25}$, que o (re)conhecimento do papel social das parteiras tradicionais e de seus saberes é essencial neste empenho coletivo por uma emancipação feminina coletiva.

Outra questão essencial nesse empenho coletivo é a necessidade constante de reflexão e autocrítica, sob pena de trocarmos uma opressão por outra, ou que mesmo no ativismo libertário acabemos por reproduzir e reforçar estruturas discursivas opressivas e sexistas. Continuando a leitura do relato de Tânia, percebemos mais uma vez o uso de um item lexical, "vocalizar", que

25 Em comunicação pessoal. 
permite a autoidentificação da autora como bem informada sobre os termos especializados do discurso da assistência ao parto, ratificada pela didatização inserida entre os parênteses logo a seguir, onde uma explicação para o termo é texturizada. Didatização essa concluída com a exortação categórica: "não confundir com gritos histéricos de dor." Sabendo-se que histérico é adjetivo relacionada à histeria, doença atribuída às mulheres pelo fato de terem úteros e definida pelo Dicionário da Língua Portuguesa da Porto Editora ${ }^{26}$ (DLPPE) (2003-2016) como “doença nervosa caracterizada pela exteriorização exagerada de perturbações de natureza emocional ou afetiva", e sabendo-se que a maioria das mulheres sente durante o parto a necessidade não apenas de "vocalizar" mas sim de gritar em alto e bom som, utilizar-se de um epíteto como esse para se referir a esses gritos denota uma reprodução de um discurso hegemônico sexista, que considera as mulheres exageradas e escandalosas quando externam suas dores, discurso esse concretizado muitas vezes na repreensão da mulher que pare por parte da equipe que a atende, não raro seguida por uma retaliação, como pode ser a negativa de assistência. E perceber que esse uso acontece mesmo por uma mulher empenhada em prol da coletividade, cujas emancipação e identidade de projeto são claramente representadas neste mesmo relato, deixa ver o quão fortes, duradouras e inculcadas podem ser as estruturas discursivas vigentes à uma época, ainda que a resistência esteja nessa mesma época tão evidentemente articulada e consciente.

Concluindo o excerto em (43), Tânia menciona, por meio de uma construção passiva, ter recebido visitas durante o trabalho de parto, visitas cujos agentes teriam sido "um beija-flor", "velas de mel”, “orações" e "carinhos". Consultando o DLPPE (2003-2016), encontramos como primeira definição para visitar o seguinte: "ir a (um lugar) com o objetivo de o conhecer ou de estar com alguém”. Nessa definição, a intenção da/o agente da visita está incluída e uma intenção requer um sujeito animado apto a intender determinado propósito. Talvez possamos mesmo afirmar que "visitar" requeira um/a agente humana/o para que tenhamos a construção de uma oração não só gramatical, mas também aceitável, caso nos atenhamos ao significado denotativo do verbo. Por isso, entendo que no relato de Tânia há aqui um deslocamento do que chamaríamos uso denotativo ou objetivo do verbo "visitar", para um lugar poético, quiçá; mas talvez esse uso explicite uma representação do místico ou sobrenatural presente na forma como relata o evento do parto. Marcada também pela "postura" dos cachorros que "nunca ficaram tão

\footnotetext{
${ }^{26}$ Usei durante o trabalho dois dicionários, inicialmente o dicionário Houaiss, enquanto escrevia no Brasil, mas como parte do trabalho foi escrito em Jena, onde não tinha acesso a esse dicionário, vali-me durante esse período do DLPPE, acessível gratuitamente na rede mundial de computadores.
} 
quietos", na oração seguinte, onde também é selecionado o qualificador "surreal" para caracterizar a maneira como tudo se passou, de uma maneira "que desafia as supostas leis do real; absurdo, bizarro, onírico", como definido naquele mesmo dicionário.

Esse aspecto místico, sobrenatural ou espiritual continua presente no excerto que segue em (44), adiante, em que a autora tece uma associação entre a experiência relatada e o paganismo. Considerar esse dado na análise contribui no intuito de melhor compreender esse processo de autoidentificação, de construção de uma identidade de resistência, em prol de um deslocamento no eixo, de um deslocamento nessa Weltanschauung, nessa cosmovisão, aí incluída a assistência obstétrica oferecida pela medicina tecnicista, predominantemente masculina e androcêntrica, para uma cosmovisão em que a mulher e o feminino não estão em segundo plano, e na qual para além de aspectos técnico-biológicos, sejam reconhecidos também fatores culturais, incluída aí a espiritualidade, quando ela se mostrar imperiosa.

Eu me sentia num belo ritual pagão, onde a natureza era parte, onde os elementos se interligavam, onde os espíritos de luz caminhavam entre nós. E eu, com as dores ficando mais intensas, entrava cada vez mais na grande caverna da deusa Gaia, a grande mãe. Me lembro de seguir os meus instintos e de ouvir os conselhos da Carla e da Carol, mas tudo foi ficando muito inconsciente, eu entrava e saia de um transe muito forte a cada contração. Não me lembro de que roupa eu usei (se é que usei), não me lembro da sequência lógica do dia, só me lembro de fazer exercícios com um pano amarrado a amoreira, o que me fazia sentir muito bem e feliz, me lembro de fazer exercícios com a bola de pilates no banho, na sala, no quintal, me lembro de vocalizar e sentir meu corpo vibrar com isso, não me lembro em que momento parei de comer (pois parecia muito impossível comer algo), e o dia foi seguindo...

Tânia avalia positivamente sua experiência como correspondente a um ritual "belo" e "pagão", e evoca a imagem greco-mitológica de uma deusa-mãe, Gaia, aprofundando na narrativa o ambiente de epifania e misticismo. Dá assim um passo no movimento de deslocamento de eixos, (re)construindo a ideia de protagonismo feminino no evento parto. Neste excerto ainda, percebe-se a repetição do verbo lembrar, numa alternância que chega a ser associável ao ir e vir das contrações - "me lembro", "não me lembro" -, no entrar e sair em um estado de "transe", algo que em religiões pagãs não costuma ser rechaçado como em religiões abraâmicas monoteístas. Nesse trecho, portanto, o que mais se faz notar no relato é o tom místico e a autonomia da parturiente em sua relação com o próprio corpo. Além disso, Tânia escreve ter seguido seus "instintos", item lexical cujo verbete no DLPPE (2003-2116) traz a seguinte definição: 
1. atividade automática hereditária, adaptada às condições de vida, relativamente uniforme em cada espécie, inconsciente da sua aparente finalidade

2. tendência ou impulso espontâneo e irrefletido

3. intuição; inspiração.

Considerada essa definição, que remete a inconsciente, espontâneo, hereditário, podemos dizer que também por meio dessa seleção lexical está representado o "retorno ao natural”, como descrito por Tornquist (2002) e já citado no capítulo referente à análise estrutural.

No próximo excerto, em (45), a autora menciona mais uma vez o medo, no "segundo momento tenso" do trabalho de parto, o medo de que fosse necessário ir para o hospital. Medo esse que já apareceu em outros momentos textuais.

Lá pelas $16 \mathrm{~h}$ eu estava com $7 \mathrm{~cm}$ de dilatação e o colo do útero ainda posterior. E tive meu segundo momento tenso, onde, mais uma vez tive que "me" enfrentar. Por conta do colo posterior, o TP estava lento, e por conta da bolsa rota esse TP não poderia passar das $17 \mathrm{~h}$, sendo então necessária a administração de antibióticos para evitar possíveis infecções, e isso só pode ser feito onde? Num hospital. E eu, só de ouvir a palavra "Hospital" gelava. Tentaríamos "acertar" o colo, para que ele ficasse mediano e, provavelmente, o TP seguisse feliz e com um tempo bom. Seria um procedimento dolorido, mas depois de tudo que fiz e passei, olhei para elas e disse: - Vamos, façam, confio em vocês e em meu corpo. (ou algo assim). Fizeram. E, em uma hora eu já estava com dilatação total e meu colo permaneceu mediano. Eu estava muito feliz, mas ao mesmo tempo num transe tão louco que me lembro de sentir a felicidade lá no fundo, porque por fora eu estava muito concentrada nas últimas contrações. Sentia um calor incrível, não conseguia comer nadica de nada, e adormecia entre uma contração e outra. Sério. E então, veio a última parte: a piscina.

Tânia representa nesse excerto do relato uma luta interior, dela com ela mesma, quando escreve “tive que 'me' enfrentar", com o "me" assim, entre aspas, deixando algo subentendido, que não necessariamente se esclarece com a leitura da parte subsequente do texto. Seria esse "me", entre aspas, algo ou alguém que não seria ela mesma, como poderiam ser encarados possíveis medos intrusos no processo? Seria o enfrentamento desse "me" um confronto interno ao processo de autoidentificação de uma mulher que, talvez nesse momento particular, não gostaria, mas tem de ser corresponsável no processo, incluídas aí as tomadas de decisões sobre qualquer intervenção a ser feita ou não? São perguntas para as quais não tenho respostas.

No período seguinte do relato, se estabelece uma série de relações causais, marcadas por "por conta", "por conta", "sendo então", e uma relação de finalidade, marcada por "para". Por meio delas, Tânia representa uma característica de seu corpo como sendo a causa de um trabalho de 
parto "lento", texturizando assim uma autoidentificação, uma avaliação negativa, aludindo novamente a uma fisiologia aparentemente falha e uma avaliação igualmente negativa do ritmo do trabalho de parto, sendo que a rapidez do trabalho pode ser considerada como um valor pressuposto nesse excerto, principalmente se considerarmos o contexto sociohistórico em que vivemos, definido pelo sociólogo Hartmut Rosa (2013, p. 19) como sociedade da aceleração. Com relação às chamadas sociedades ocidentais na atualidade, Rosa exemplifica processos sujeitos a essa aceleração:

Os atletas sempre parecem correr e nadar mais rápido; fast food, speed dating, power naps e drive-through funerals demonstram a nossa determinação em acelerar o ritmo das ações cotidianas; os computadores tem cada vez mais alta velocidade, transportes e comunicações, só de uma fração do tempo que era necessário apenas um século atrás, as pessoas parecem sempre dormir menos [...], e até mesmo os nossos vizinhos parecem se mudar com mais frequência.

Todos esses processos de aceleração não são considerados por Rosa como processos isolados, mas sim como parte de um sistema de aceleração característico da idade moderna. As evoluções tecnológicas teriam contribuído para essa aceleração. Podemos afirmar isso também observando as "tecnologias do parto", como o uso de hormônio sintético para a aceleração do trabalho de parto ou da cirurgia, capaz de comprimir as "longas" horas de trabalho de parto em “curtos" cinquenta minutos. No caso do texto de Tânia, que pode ser identificada como participante em um movimento que visa à desaceleração do ritual do parto, isso não nos impede de considerar a qualificação do trabalho de parto como lento como uma avaliação negativa, demonstrando o quanto isso diz respeito não a uma atitude individual, mas a valor sistêmico discursivamente (re)produzido e comunicado. Enfim, seguida dessa dupla avaliação negativa, com relação a seu corpo e ao ritmo do TP, Tânia texturiza as próximas relações de causalidade, "por conta da bolsa rota" e "sendo então necessária a administração de antibióticos", deixando assim representada a possibilidade de que ocorram intervenções em cascata (Diniz \& Chacham, 2006) mesmo quando o parto é assistido em domicílio e que, também nesses casos, uma intervenção para acelerar o processo pode ser causa da necessidade de transferência para um hospital, sem que haja como saber se o processo (não) teria se desenvolvido bem fisiologicamente, caso o medo e a ansiedade, na mulher e na equipe de assistência, não tivesse motivado a intervenção, como foi no parto de Tânia com a rotura da bolsa amniótica.

Diante do medo de ir para o hospital, palavra que segundo Tânia, a fazia "gelar", ela afirma “tentaríamos" - mais uma vez na primeira pessoa do plural, que, se inclui a agência da equipe, não exclui sua agência ou protagonismo nas ações exigidas pelo momento. Sua palavra é a final: 
"Vamos, façam, confio em vocês e em meu corpo". Apesar da ambiguidade presente em "vamos", que tanto pode significar uma instrução para a ação de outrem, como pode significar mais uma vez a autoinclusão, por parte de quem fala, no ato a ser executado, esta segunda possibilidade marcaria mais uma vez o protagonismo de Tânia na representação de sua vivência. O "façam", entretanto, denota a entrega e a confiança na equipe, reafirmada a seguir, juntamente com a confiança no corpo, em segundo lugar. A inclusão, entre parênteses, da expressão "ou algo assim" evidencia a pressuposição de que a memória do que teria dito exatamente nesse momento não está tão clara, o que por sua vez permite supor que, na falta dessa observação, com relação às demais falas, a autora acredite estar de fato fazendo menções literais no restante do relato.

Na sequência do excerto, Tânia utiliza duas expressões que gostaria de enfocar a seguir: "transe tão louco" e "muito concentrada". Na primeira, a autoidentificação que ocorre é a de uma mulher desconectada da consciência, envolta quase que em uma alucinação, mas a identificação é múltipla e diversa ao mesmo tempo, e, porque não dizer, paradoxal, pois se completa com a afirmação de estar, ainda que exteriormente, "muito concentrada" em suas contrações. Essa representação nos faz questionar sobre quanto (des)controle, quanto (in)consciente é necessário, possível, útil ou benéfico no momento do parto, especialmente sabendo que muitas ativistas defendam a necessidade de desconexão com o consciente, a necessidade da ação impulsionada por instintos inconscientes para o sucesso do parto.

No excerto subsequente, reproduzido em (46), a seguir, a autora fala do (re)nascimento na piscina e se utiliza de uma metáfora animal, evocando a figura da Leoa, assim, com letra maiúscula:

(46) A água estava morna, eu nua, todos ao redor, inclusive minha filha Gaia (que tem 5 anos), que ficou ao meu lado o tempo todo, jogando água em minhas costas.

Do lado de fora eu pude ver pela janela (e depois, pelo que me contaram) a amoreira, uma bela nuvem de chuva e sol. Um cheiro de mel (por conta das velas), um silêncio e meus urros. Sim, durante estas últimas contrações minhas vocalizações se tornaram urros, que me davam força, me aliviavam. Sentia minha alma instintiva gritar a mesma voz. A Leoa tomou meu ser e a cada gota de chuva que caia no quintal mais eu entrava nos meus instintos, mais eu sentia cada célula feral tomar conta de mim, mais eu sentia a exuberante luz preenchendo minha vagina e meu ser racional e medroso morrendo. Tive lapsos de consciência, mas as contrações me puxavam de volta. E eu tinha que segurar nas mãos de alguém. Nem lembro quais mãos eu peguei, mas tinha que segurar em alguém. De repente, senti uma mãozinha bater na minha coxa e dei meu último urro. Depois de 30 minutos de expulsivo na piscina, as $17 \mathrm{~h} 38$ do dia 14 de Maio de 2013, nosso iluminado Tauri nasceu com $3 \mathrm{~kg} 560$ e $50 \mathrm{~cm}$. 
Todos choraram. Olhei para ele e ouvi alguém falando : -Vai, pega ele. E eu peguei. E tive o momento. Segurei ele junto a mim, lhe dei as boas vindas e senti o universo abençoando aquele momento. Um momento de luz e renascimento. Onde todos choravam felizes. Onde minha cicatriz se curara. Onde as palavras não tinham vez. Só os olhares.

Nesse excerto, Tânia faz uma seleção lexical alternativa para os sons que emitia, agora não mais "vocalizações", nem tampouco "gritos histéricos", como já visto e problematizado. Com relação a esse momento, descrito detalhamente, Tânia menciona seus "urros", ou seja "som forte e estrídulo emitido por alguns animais; bramido"27. Com essa lexia, a autora contribui para a composição textual da imagem metafórica afeta à animalidade com a qual se autoidentifica nesse momento. Essa animalidade traz a "anima", a alma, não somente no interior da lexia em si, mas também no campo semântico evocado pela expressão "alma instintiva", que compõe a imagem segundo a qual o evento do parto é representado como algo ligado ao animal irracional, mas também ao imaterial, invisível, esotérico ou espiritual. Essa "alma instintiva" sintonizada com a mulher "fera", de carne e osso, "gritava a mesma voz", compondo uma sinfonia harmônica entre esses dois, ou melhor, três planos: o humano, o animal e o espiritual. A essa altura o tom da narrativa torna-se sinestésico, num feixe de sensações táteis, auditivas, olfativas que é aqui rememorado.

O excerto continua com a metáfora da Leoa. Aqui é evocada a Leoa, a soberana, seguindo a construção de um feminino que não se submete, por ser capaz de renascer e curar, como nesse "momento de luz e renascimento". O foco também está no instinto, contraposto ao racional, "meus instintos", "meu ser racional", o que volta a enfatizar sua autonomia nesse momento. A seleção da lexia "célula feral" associada a "tomar conta", seguida da "exuberante luz" que preenche sua vagina, são mais duas pinceladas textuais nesse quadro produzido por Tânia. Estilisticamente, a inversão da ordem canônica, com a anteposição do adjetivo exuberante denota o esforço poético que a autora emprega nessa descrição de seu parto domiciliar. Esse esforço pode ser reconhecido como parte da atitude que permite reconhecer sua identidade de resistência e projeto (Castells, 1999) emancipatório coletivo, assim como a vontade de construir discursivamente uma imagem positiva, poética do parto, que alcance outras mulheres - como sugere igualmente o excerto seguinte. 
O excerto em (47), a seguir, trata da 'volta ao mundo' após essa vivência de transe, animal e espiritual. E depois da volta ao mundo, a volta às coisas do mundo e à luta cotidiana, com um apelo às mulheres, como veremos na sequência:

Após alguns minutos, o cordão parou de pulsar e meu marido o cortou. O Tauri foi examinado pela Carla enquanto eu saia às pressas da piscina pois minha placenta queria "vir ao mundo". A Carla aqueceu o Tauri e depois colocou ele em meu colo para mamar. Enquanto isso, foi me examinar, ver se a placenta estava íntegra, se eu precisaria de alguns pontos, enfim. Perdi bastante sangue, mas tudo estava bem e normal, este, aliás, foi o único momento em que minha filha ficou assustada, pois ela tem pavor de sangue. Foram dados 2 pontinhos na mucosa (só por precaução, pois não tive lacerações musculares nem nada), pois o Tauri nasceu com a mãozinha no rosto.

Estávamos todos em êxtase. Eu voltei a ouvir minha voz, pois, durante o TP eu percebi que não ouvia a minha voz, não via as coisas da mesma maneira, e de repente voltei "ao mundo". Estava radiante. Todos estávamos.

Eu achava que, depois de 14h de TP estaria sem forças, cansada, abatida... mas aconteceu exatamente o contrário. Ninguém negava o cansaço físico, mas este era superado pelo êxtase praticamente espiritual. A todo o momento eu me perguntava: - puxa, isso realmente está acontecendo? Será que não estou sonhando? Não conseguia acreditar. Senti que, se eu fui capaz de enfrentar tudo que enfrentei, desde a jornada antes do parto, até o parto em si, seria capaz de enfrentar qualquer coisa. Senti que tudo vem de encontro com o que pedimos e fazemos, e sim, nada é impossível. Uma ultra superação pessoal, física, espiritual. Algo que desejei muito, tanto pelas minhas razões pessoais, quanto por todas as outras mulheres que, assim como eu, passaram por cesáreas desnecessárias ou qualquer violência obstétrica, para mostrar que sim, podemos mudar essa realidade, que podemos confiar em nossos corpos, que somos forte e sagradas, que temos o DIREITO de parir e de sentir toda essa luz. Que podemos mais. Sempre.

Busquem a verdade. Lutem pelos seus diretos. Vivam seus sonhos. Vamos mudar juntas o nascimento de um novo mundo.

Agradeço do fundo do meu coração e da minha alma a todos e todas que me ajudaram, que oraram, que torceram por este parto. Em especial ao meu marido, minha filha e filho, a Carla, a Carol, a Tábata, a Melissa e a Dani.

Com esse excerto, (47), finaliza-se o relato. Já nas duas primeiras linhas do excerto, ela se utiliza duas vezes do elemento conjuntivo "mas", seguindo o movimento constante de deslocamento em seu texto e promovendo uma perspectiva alternativa sobre o parto e as possibilidades femininas. Nesse processo, se autoidentifica como parte integrante de um sujeito coletivo, que tem suas razões pessoais, mas também leva consigo as razões de "todas as outras mulheres que [...] passaram por cesáreas desnecessárias ou qualquer violência obstétrica". A autora amplifica o volume, repetindo três vezes a afirmativa "podemos", antecedida pelo elemento de reforço "que sim", como que em resposta às alternadas negativas expressas em seu relato, às tantas possibilidades de não conseguir viver seu parto. Com isso, a poucas linhas de concluir seu relato, identifica, expressamente, a si mesma e a todas "nós mulheres", incluídas 
em seus "podemos", como plenas de "DIREITO de parir e sentir toda essa luz". O “.Sempre.", compreendido entre dois pontos finais, marca início e fim de todo o tempo em que podemos, categoricamente e sem concessões.

E é diante dessa identidade feminina coletiva que a autora muda o tom narrativo para realizar uma injunção: lança mão do imperativo, "busquem", "lutem”, “vivam” e "vamos”, num convite enfático à construção de uma identidade de resistência e projeto. Une, assim, sua voz às vozes ativistas contra toda forma de violência obstétrica, em luta pela autonomia e o protagonismo no parto, garantidos os direitos sexuais e reprodutivos das mulheres.

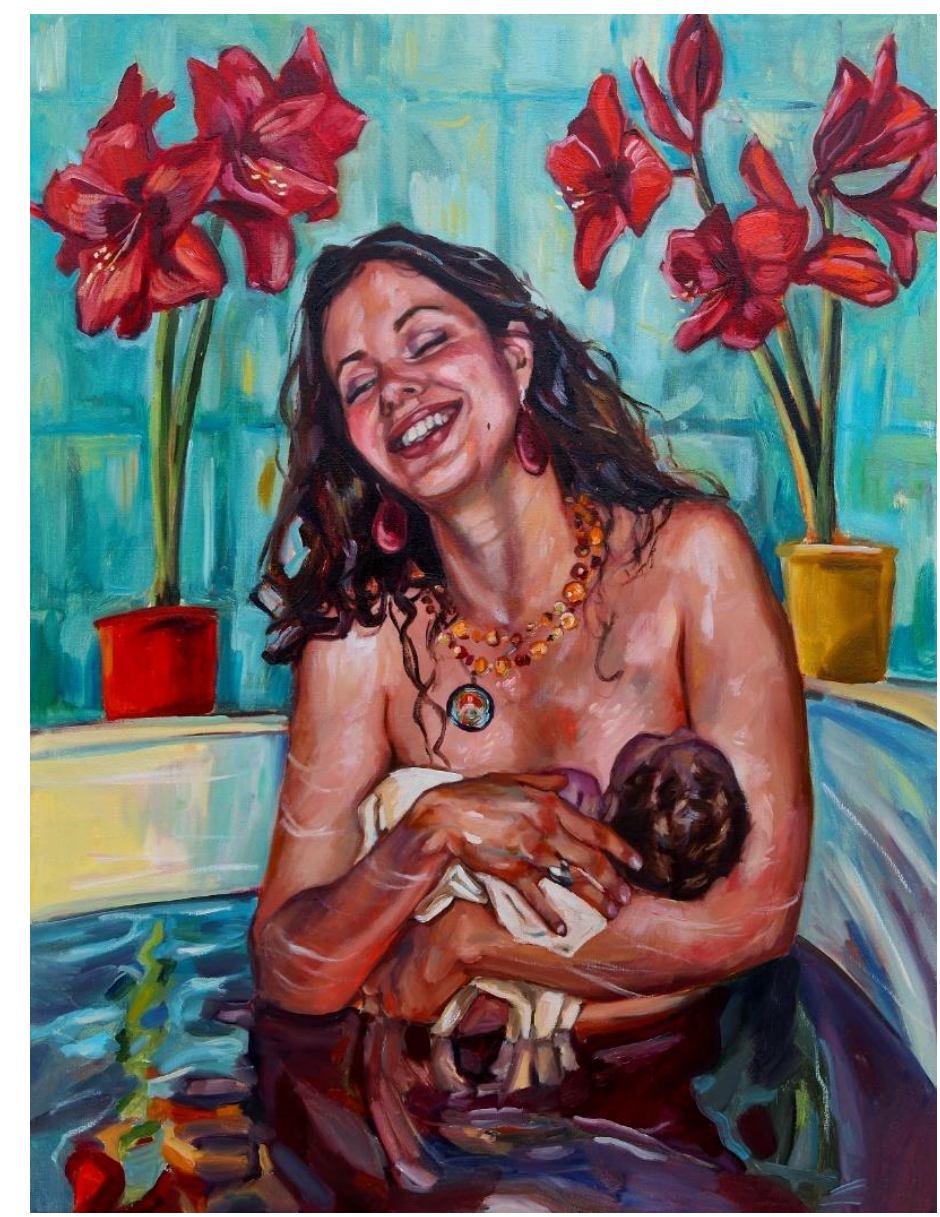

Figura 5 - "Our mouths are filled with laughter, our tongues with songs of joy", obra da artista canadense Amanda Greavette, cujo trabalho, The birth project, também é uma iniciativa promotora de mudanças na representação do parto.

4.2. Análise fina do relato de Lívia. "Não, meu medo nunca foi parir".

O relato cuja análise apresento a seguir, o relato de Lívia, foi coletado do site da Casa Moara, um espaço de convivência dedicado a mulheres grávidas e a suas famílias na cidade de São Paulo. Lívia era atendida havia muito tempo por uma médica, mas durante a gestação não se 
sentiu correspondida em seu intento de fazer todo o possível para que sua gestação tivesse seu ápice num parto natural, e resolveu mudar a equipe de assistência, que, a assistiria durante o trabalho de parto, após o qual veio ao mundo seu filho, em um parto vaginal hospitalar sem intervenções consideradas desnecessárias.

$\mathrm{Na}$ apresentação da análise, trarei os fragmentos selecionados dentre aqueles que, durante a etapa da análise estrutural realizada com o auxílio do software, identifiquei como relativos à autoidentificação da mulher com relação ao período pré-natal e ao parto. Como nesta análise optei não por uma análise do texto na íntegra, como o fiz com o relato de Tânia, mas por um recorte transversal temático, focado somente na autoidentificação. Fiz a opção por esse recorte de forma a contemplar o aspecto temático mais presente no corpus analítico, nomeadamente, a autoidentificação. Reproduzo, contudo, a íntegra do texto no Anexo 2 pois acredito que sua leitura prévia possa ser interessante, caso alguém tenha queira conhecer toda a narrativa.

O relato de Lívia tem início com o excerto apresentado em (48), versando sobre a descoberta da gestação e de sentimentos a ela relacionados, também aqui com o aspecto autobiográfico da marcação exata do início da história, que tem início meio e fim, com uma curva dramática, ou seja, um ponto de "conversão" de um eu anterior para o eu narrador.

(48) Meu relato de parto começa muito antes de parir: quando nos descobrimos grávidos, cada um sentiu um frio na barriga diferente. No caso do Marcos, me pareceu carregado de felicidade e realização. O meu veio acompanhado por um vendaval estomacal repleto de medo. Medo das mudanças, da responsabilidade, de não ter trabalhado o suficiente, de me doar, de não sentir o amor incondicional, de não saber cuidar, de não saber ser mãe, e claro!, o medo de passar por uma cirurgia. Não, meu medo nunca foi parir.

Nesse excerto, percebe-se, já na segunda linha, um uso linguístico denormalizador, que subverte uma "normalidade", a concepção tradicional da gestação como algo referente somente à mulher. Assim, Lívia ressalta a figura do pai como co-protagonista nesse processo que extrapola a fisiologia, envolvendo inúmeros aspectos socioculturais que influenciam diretamente no (bom) andamento da gestação e do nascimento.

Ao escrever "nos descobrimos grávidos", Lívia aciona várias questões relacionadas às maneiras como discursivamente se constituem os lugares subjetivos da mulher e do homem nesse processo, representações cujos efeitos na prática podem ser, por exemplo, profissionais de saúde aceitarem e cumprirem (ou não) a Lei Federal 11.108, de 2005, que prevê o direito de que a mulher tenha um/a acompanhante de sua escolha durante o pré-parto, o parto e o pós- 
parto imediato. Lei cuja execução, como já mencionado, encontra muitas vezes resistência por parte de profissionais da assistência obstétrica, especialmente quando se trata de um acompanhante do sexo masculino. Esse rotineiro descumprimento da lei motiva a resistência de famílias engajadas na luta pelos direitos da mulher parturiente, por exemplo por meio da campanha "Pai não é visita. Pelo direito de ser acompanhante", iniciada pelo Instituto Papai, em parceria com o Grupo de Estudos em Gênero e Masculinidades da Universidade Federal de Pernambuco, e apoiada veementemente por mulheres engajadas em redes nacionais de defesa do direito humano a um parto assistido com respeito. Nesse empenho se insere, de acordo com minha análise, também essa denormalização inscrita no relato de Lívia, que representa a gestação como algo que se refere não somente a ela, mas também a seu companheiro.

$\mathrm{Na}$ sequência do fragmento em (48), Lívia menciona quatro vezes a palavra medo, intensificando por meio de repetição (Martin \& White, 2005) e mais uma vez denormalizando o pressuposto "medo do parto". Dos medos apresentados, num crescendo, o maior deles é "o medo de passar por uma cirurgia", em contraposição direta ao medo de parir, negado duas vezes, com "não" e "nunca". Ao dar início a essa assertiva com um "não", Lívia deixa evidente que supõe encontrar essa expectativa nas/os possíveis leitoras/es de seu relato. E com o reforço de uma dupla negativa (Pardo, 2011; e Martin \& White, 2005), "não" e "nunca", rebate e denormaliza essa expectativa, promovendo um desvio na rota desse fluxo discursivo, imprimindo mais peso a outras questões relativas à maternidade e naturalizando o parto iminente, como algo que não deveria ser assustador.

Mais adiante em seu relato, em (49), a seguir, Lívia menciona seu estado de espírito durante a gestação: "feliz e saudável". Entretanto, não deixa de denormalizar: questionadora, volta a incluir a figura paterna como diretamente envolvida no "próprio" parto, ao mencionar o "nosso parto", ao tempo em que, de certa forma, desmerece a figura da médica ao selecionar o epíteto "a tal" para se referir a ela:

(49) O tempo foi passando, eu me sentia cada dia mais feliz e saudável. Passei a me questionar sobre como realmente seria nosso parto e resolvi entender da tal médica, sempre evasiva, afinal de contas, como é que seria o parto na visão dela.

Com o pré-natal mais avançado, e depois de concluir que aquela médica não era a profissional considerada adequada para acompanhá-la no propósito de trazer o filho ao mundo "de forma mais natural”, Lívia fala do prazer em estar grávida, em (50): 
Com 32 semanas e alguns amigos nos guiando, conhecemos a nossa obstetriz e aquele que viria a ser nosso médico parteiro. A sensação ao sair das consultas eu nunca vou esquecer... é difícil achar palavras pra descrever, mas foi como respirar novos ares. Pela primeira vez eu senti muito prazer em estar grávida. Tudo fez sentido, pois minha vontade seria respeitada, afinal de contas, alguém estava me ouvindo. Não precisou muita conversa pra que eu entendesse o sentido da humanização, não só do parto, mas de todo o processo até chegarmos a ele. A obstetriz é uma fonte de energia e serenidade. O médico parteiro, um ser humano apaixonante. Ambos amam o que fazem e fazem com respeito.

Gabriel García Márquez escreveu um dia sobre um tempo em que "o mundo era tão recente que muitas coisas careciam de nome e para mencioná-las se precisava apontar com o dedo”. Maria Bethânia canta os versos de Arnaldo Antunes falando de um lugar protegido e salvo, mas onde não se podia respirar. E o relato de Lívia me remeteu a esses autores, àquela citação e a esta canção, pois sua dificuldade em "achar palavras pra descrever" sua sensação ao se deparar com a possibilidade, tão remota no contexto sócio-histórico em que vivia, de ser ouvida e de ter sua vontade respeitada, alude à ideia de um mundo novo, cheio de coisas ainda não nomeadas.

A metáfora biológica da respiração, de "novos ares", remete também ao pressuposto de falta de ar, de falta de opção com que se deparam casais grávidos quando resolvem ser protagonistas de seu parto e não apenas delegar, de olhos fechados, a responsabilidade do evento e da tomada de decisões necessárias a um/a médica/o toda/o poderosa/o. Numa situação assim, ter "alguns amigos [...] guiando", pode ser essencial, configurando mais uma vez, também na representação do relato de Lívia, a necessidade de uma "rede permeada pela subjetividade" (Maturana \& Zöller, 2004, p. 140 apud Borges, Pinho \& Santos, 2009, p. 378), fomentando afetos e vínculos fundamentais para uma assistência de fato bem sucedida e garantidora de direitos sexuais e reprodutivos para as mulheres.

Nesse fragmento ainda, o uso de marcadores de modalidade categórica, como "nunca", "Tudo" e de reforçadores como "muito", denotam a plenitude sentida por essa mulher que, "Pela primeira vez", acreditava na possibilidade de ser respeitada e ouvida durante o parto, sendo que isso se deve ao encontro com esse "médico parteiro". Reparemos na seleção lexical: Lívia poderia ter mencionado o "médico" ou o "parteiro", mas escreve "médico parteiro", e não "médico obstetra", por exemplo, termo cunhado e estabelecido, uma normalidade vigente. Por meio de sua escolha linguística, Lívia contribui para a normalização ou constituição de uma nova possibilidade discursiva, um médico que reuniria em si tanto os conhecimentos e a formação da medicina acadêmica, quanto os saberes tradicionais da parteira. E o encontro com esse ator social lhe permite, numa ruptura, num ponto de inflexão, "pela primeira vez senti[r] 
muito prazer em estar grávida", com direito ao reforçador "muito", algo que se distancia da metáfora climático-fisiológica presente no fragmento em (48), "um vendaval estomacal repleto de medo", quando, entre outros, reinava o "medo de passar por uma cirurgia". Medo que não era de fato infundado, se considerarmos as estatísticas dos nascimentos no Brasil, com mais de $50 \%$ dos nascimentos acontecendo por meio de cirurgias cesarianas.

Na sequência de seu relato, com a relação de causalidade denotada em "pois", na primeira linha do segundo parágrafo do fragmento em (50), Lívia levanta o pressuposto de que a (des)assistência como tem acontecido não faria sentido, por não respeitar a vontade da mulher, por não ouvi-la. De fato, como afirma Diniz (2009, p. 317),

o modelo típico de assistência ao parto em muitos serviços do SUS, além de inseguro e pouco apoiado em evidências científicas, é não raro marcado por uma relação profissional-usuária autoritária, que inclui formas de tratamento discriminatório, desumano ou degradante.

Ou seja, é perfeitamente possível pressupor que em meio a uma relação autoritária, com tratamento desumano ou degradante, o ouvir e atender os anseios da parturiente não encontre espaço.

Continuando, Lívia avalia a obstetriz e o médico parteiro, concluindo o parágrafo que se inicia com a avaliação categórica de que "tudo fez sentido", atribuindo isso ao amor e ao respeito com que exercem sua profissão. Lívia ressalta, ainda, ter entendido o "sentido da humanização", compondo esse campo semântico com as lexias "energia", "serenidade", "amor" e "respeito", tudo isso associado a termos técnicos como "obstetriz" e "médico", ainda que "parteiro". Embora obstetriz apareça no dicionário Houaiss de Língua Portuguesa como sendo o mesmo que parteira, sabemos que, discursivamente, os dois termos têm efeitos distintos. Parteiras são chamadas, tradicionalmente, as mulheres leigas que assistem outras mulheres durante o trabalho de parto, sem ter necessariamente uma formação acadêmica ou uma escola formal, o que, entretanto, não quer dizer que não devam ser reconhecidas como fontes de saberes históricos sobre a arte de partejar. Conforme definem Borges, Pinho \& Santos (2009, p. 376-7),

as parteiras constroem nas suas interações e práticas sociais do cotidiano um conjunto de representações do cuidado em saúde que pode se constituir como possibilidade futura de prática educativa que envolva os profissionais da saúde, pela possibilidade do reconhecimento e da articulação dos diferentes modos de saber cuidar. 
Obstetrizes, por sua vez, são egressas do único curso universitário que forma obstetrizes no Brasil, na Universidade de São Paulo. Na página oficial do curso, lê-se, em resposta à pergunta, “O que é obstetrícia?”, que

a Obstetrícia é a ciência que estuda a reprodução humana. Investiga a gestação, o parto e o pós-parto nos seus aspectos fisiológicos e patológicos. O termo "obstetrícia" vem da palavra latina "obstetrix", que é derivada do verbo "obstare" (ficar ao lado). Para alguns, seria relativo à "mulher assistindo à parturiente" ou "mulher que presta auxílio". 28

Portanto, a obstetrícia seria uma ciência, uma investigação da reprodução humana, de seus aspectos fisiológicos e patológicos. A palavra parteira não aparece nenhuma vez na página que responde a essa pergunta, embora saibamos que algumas pessoas entendam que obstetrizes sejam 'parteiras diplomadas'. Podemos dizer que a obstetriz seria uma parteira "cientificada" e o médico parteiro, um médico que além da técnica e da formação universitária teria a sabedoria e a paciência não intervencionista de uma parteira tradicional. Com relação à formação da parteira tradicional, Santos $(2010$, p. 25) afirma que

[t]odas têm em comum o conhecimento do ofício, adquirido na transmissão oral, a partir de parteiras mais velhas e transmissoras consideradas importantes e competentes, frequentemente da família, mães, sogras, parentes próximas, amigas e vizinhas, por quem nutrem laços afetivos e com quem vivenciaram suas experiências de parir e de partejar. Introduziram-se nesse ofício como auxiliares de parteiras e aprendizes, ou deparando-se com a urgência de atuar nesta arte.

Sabemos que, discursivamente, as seleções lexicais nunca são neutras e trazem sempre em seu bojo uma avaliação pressuposta. Selecionar ou não a denominação parteira, selecionar ou não o termo obstetriz é sempre indicativo de certo enunciado (M. Jäger, no prelo) sobre as práticas a serem reconhecidas e promovidas, ou não. Marjorie Tew (1990), versando sobre a hospitalização do parto no Reino Unido e sobre a integração de parteiras no ambiente hospitalar, lembra que ataques às habilidades profissionais das parteiras geraram a forte aspiração por parte das parteiras para que sua profissão fosse regulada. Mas, ironicamente, o sucesso em atingir essa meta não aconteceu sem que fosse sacrificada a sua tradicional supremacia como provedoras da assistência obstétrica. Com o passar do século XX, parteiras com treinamento formal, o que poderíamos chamar obstetrizes, substituíram parteiras tradicionais ou curiosas,

28Página do Curso de Obstetrícia da Universidade de São Paulo, disponível em <http://www.each.usp.br/obstetricia/obstetricia.htm>, consultada em 10 de março de 2016. 
mas seu papel foi cada vez mais subordinado ao da/do médica/o obstetra, transformando-as assim, no final das contas, de fato, em enfermeiras obstétricas a auxiliar as/os médicas/os. Essa integração constitui afinal uma desintegração, uma presença que é ausência, um silenciar das parteiras tradicionais e se seu modus operandi. Desde uma perspectiva da Sociologia de Ausências e Emergências, modelo epistemológico proposto por Boaventura de Souza Santos (2004), Borges, Pinho \& Santos (2009, p.374) escrevem que "a ciência moderna, ao produzir existências, também produziu ausências" e que a consequência disso seria "o nãoaproveitamento dos diferentes saberes e experiências", um "desperdício da riqueza social". Levando isso em conta, é interessante observar que ofícios são selecionados, não somente nos textos aqui analisado, mas também na atuação de ativistas pelo direito a um parto digno.

Voltando ao texto de Lívia, apesar de estar agora sendo acompanhada pela equipe que desejava, seu relato ainda contém bastante "medo". Ainda que esse medo seja incluído para ser negado, ele sempre volta a ser mencionado, como no excerto em (51), em que esse vocábulo ocorre mais oito vezes.
Adiante com o pré-natal, agora respirando novos ares. Uma pergunta sobre o parto que o médico parteiro fez nas consultas foi: "Você tem medo de quê?" Eu ainda estava com alguns medos, verdade. Por vezes tentei responder essa pergunta a ele, e até inventei um medo: "Medo da pressão subir e eu passar mal no meio do parto", rs. Acho que ele não acreditou, mesmo assim com um punhado de palavras rebateu o "pseudo medo".
Não tenho medo da dor, nem da passagem do bebê, nem mais a placenta me põe medo. Entendi que do parto é que eu não tinha medo.

Como podemos ler, todas essas menções ao medo, repetições lexicais que reforçam e intensificam esse sentimento, são mais uma vez realizadas para lembrar que entre todos esses medos possíveis, na realidade "pseudomedos", não estava o medo de parir - mais uma vez denormalizando o senso-comum segundo o qual o parto seria um evento temível. No fragmento temos o pressuposto do medo, levantado pelo médico; a assunção do medo, com uma alta modalidade epistêmica, ou seja, relacionada ao teor de verdade desse medo, embora trate-se de um medo desconhecido e que ela desqualifica como um "pseudo medo".

A clivagem "é que" funciona como um reforço na negativa do medo do parto. Aqui percebemos um exemplo de ação contradiscursiva, assim como escreveu Margarete Jäger (no prelo) citando Foucault: 
minar e decompor o poder: "Os discursos, assim como o silêncio, não são submetidos ao poder ou posicionados contra ele para todo o sempre. Trata-se antes de um jogo complexo e instável, no qual o discurso pode ser, ao mesmo tempo, um instrumento ou um efeito de poder, mas também obstáculo, contraponto, ponto de resistência e de partida para uma estratégia contrária." (Foucault, 1983, p. 100).

Quando relata o momento em que a bolsa amniótica se rompeu, quando estava num restaurante em companhia de familiares, que entraram em pânico, Lívia escreve, em (52) a seguir:

O tempo parou, olhei a minha volta e disse com um sorriso largo no rosto: "Garçom, cancela o pedido, pois minha bolsa rompeu". Meu primo e a esposa dele ficaram em pânico, umas senhoras que estavam no restaurante me olhavam sorrindo e dizendo "Bom parto minha filha".

Achei graça a bolsa ter rompido. A sensação do líquido escorrendo pelas pernas foi carregada de felicidade e realização. Não tive medo. Sorri em resposta às senhoras e acalmei meus primos. Pedi que me levassem para casa e não para o hospital como eles sugeriram.

Mais uma vez, em (52), a seleção lexical compõe um campo semântico denormalizador, ao associar esse rompimento da bolsa amniótica a expressões como "um sorriso largo", "olhavam sorrindo", "achei graça”, "felicidade e realização", "sorri”, "acalmei”". Denormalizador do "pânico dos familiares" e da expectativa de que a mulher nessa situação sentisse "medo". Nessa última passagem, completando quinze ocorrências dessa palavra "medo", que é incluída no relato para ser desconstruída, denormalizada, há mais um movimento de intensificação da negação do medo do parto, medo que é representado, é incluído e reconhecido como padrão discursivo para ser minado.

Ainda no fragmento em (52), são acionados dois dispositivos: a "casa" e o "hospital". Os dispositivos têm uma função estratégica, como salienta Margarete Jäger (no prelo), apoiandose em Foucault. Segundo ela, "eles se constituem em situações sociais específicas, servem para lidar com ou solucionar problemas no âmbito dessa constelação". Embora neste trabalho o foco esteja voltado para o discurso, ou seja, o lado linguístico do dispositivo, na representação desse contraponto casa-hospital aparece mais uma maneira discursiva de subversão da ordem vigente, da prática naturalizada, normalizada recentemente, de se conduzir as mulheres em trabalho de parto para hospitais. Note-se que tanto a casa quanto o hospital são instituições sociais surgidas para lidar com necessidades humanas específicas e que, no Brasil, até bem pouco tempo, o espaço da casa também previa o parto como parte das necessidades a serem atendidas por esse dispositivo. Mott (2002, p. 207) afirma que, em 1945, 70,4\% dos partos do maior município do Brasil, o município de São Paulo, ainda aconteciam em casa. 
Lembremos aqui o acontecimento discursivo (M. Jäger, 1996; S. Jäger, 2012), ocorrido em 2012, quando um vídeo de parto domiciliar compartilhado e muito acessado na internet motivou uma reportagem apresentada por um programa televisivo de ampla difusão, num domingo à noite, no qual um médico de São Paulo se pronunciou favoravelmente ao parto domiciliar, acontecimento que provocou uma reação imediata do Conselho Regional de Medicina do Rio de Janeiro (CREMERJ), que no dia seguinte denunciou o médico ao Conselho Regional de Medicina de São Paulo, por ter se posicionado daquela maneira, pois o parto envolveria muitos riscos e deveria sim ocorrer em local equipado e com uma equipe 'preparada para lidar com esses riscos'.

O CREMERJ se posicionou ainda, formalmente, contrário à realização de partos domiciliares e "publicou as resoluções 265 e 266, declarando vedadas tanto 'a participação do médico nas chamadas ações domiciliares relacionadas ao parto' quanto 'a participação de pessoas não habilitadas e/ou de profissões não reconhecidas na área da saúde durante e após a realização do parto, em ambiente hospitalar', e incluindo expressamente nessa proibição 'as chamadas 'doulas', 'obstetrizes', 'parteiras' etc.” (Regis, 2015, p. 4731).

Uma forte contrarreação a esse posicionamento, considerado arbitrário, foi a chamada Marcha do Parto em Casa, que aconteceu no domingo seguinte com a participação de centenas de pessoas por todo o país; um dos gritos de guerra entoados por participantes clamava: "no hospital eu sou mãezinha, na minha casa eu sou rainha". Grito esse que, fazendo alusão ao vocativo frequentemente utilizado por profissionais de saúde ao se dirigir à mulher em trabalho de parto (ou acompanhando filhos/as em consulta pediátrica, como observou Magalhães, 2000), denuncia o diminutivo que contribui para que a mulher entenda que deva se pôr no devido lugar, por não estar em sua casa. O estar em casa ou no hospital, o ser chamada de mãezinha ou ser chamada pelo próprio nome, cada uma dessas possibilidades tem efeitos discursivos e serve, potencialmente, ao que Fairclough $(2003$, p. 208) chama inculcação, à constituição de nosso posicionamento subjetivo.

Essa inculcação pode atuar na determinação do "endereço da mulher", como o definiu Helmstetter (2003, p. 183), que argumenta que o ser humano não se torna ser humano já pelo nascimento ou pela criação, mas só por meio de seu lugar na ordem simbólica, na qual precisa ser inserido. Um dispositivo comunica esse endereço de diversas formas, tanto pelo discurso concretizado nos usos linguísticos dos atores sociais que ali atuam, quanto naquele concretizado em edificações, objetificações, limitações espaciais, como as que constituem a casa e o hospital, 
por vezes com semelhanças, mais na maioria das vezes com efeitos discursivos bastante distintos, especialmente na constituição subjetiva da mulher que está em trabalho de parto. Por isso, podemos considerar denormalizador, também nesse fragmento em (52), o relato de Lívia e o registro de que queria ir para casa e não para o hospital.

Sobre o momento em que chegou à casa, Lívia escreve, no excerto em (53):

A caminho de casa as contrações começaram... não achei graça nisso. Liguei para o Marcos e quando cheguei em casa tive uma sensação de alívio (não nas dores) emocional. Vi que ele preparou a casa pra mim: baixou as luzes e colocou as músicas que escolhemos para o parto. Sentir que ele estava lá, presente em todos os sentidos, foi a maior segurança que eu podia ter.

Em (53) lemos que, se a graça diminuiu e as dores não aliviaram, houve alívio emocional, e "a maior segurança que [...] podia ter”. E essa segurança é atribuída à presença do companheiro ao seu lado naquele momento, com a casa preparada para ela, com o conforto de suas músicas, portanto ao dispositivo da assistência como um todo, incluídas aí a ação não-verbal e a produções humanas baseadas em conhecimento (S. Jäger, 2012, p. 73). Todo esse cenário é o oposto do que a maioria das mulheres vivencia em um hospital qualquer, num ambiente estranho e sem direito a um/a acompanhante de sua escolha, com muita luz e pouca privacidade, cujas implicações fisiológicas podem incluir um trabalho de parto mais sofrido e uma experiência que justifica o medo comunicado depois de diversas maneiras e que motiva muitas mulheres a buscar uma saída menos amedrontadora, como, por exemplo, algo que pode parecer, à primeira vista, bem mais tranquilo, como uma cesárea agendada. Como escreveu Diniz (2009, p. 313), a “"pessimização do parto’ é instrumental para favorecer, por comparação, o modelo da cesárea de rotina".

Mais adiante em seu relato, referindo-se já à fase expulsiva, quando já estava no hospital, Lívia age mais uma vez denormalizando estruturas discursivas quando menciona a vontade de fazer força, em (54).

(54) Sempre imaginei como seria a tal vontade de fazer força. Seria psicológica? Racional? Ou física? Física! Senti o corpo se contrair por vontade própria, como um espasmo, um movimento involuntário.

É disseminado o costume de pedir à parturiente que faça força em algum momento do parto, possivelmente quando profissionais da assistência obstétrica acreditam que é chegada a hora e que o empenho voluntário da mulher seja indispensável. Entretanto, Lívia racionaliza e expõe 
o que teria sido sua experiência, afirmando que o movimento é involuntário. Portanto, seria desnecessário e, por que não dizer, até contraproducente ficar dizendo à mulher que deva fazer força, gerando uma pressão psicológica ao responsabilizá-la por algo sobre o qual inexiste controle. A construção textual do relato tem um efeito quase onomatopeico, não no sentido fonético, mas na reprodução da onda de movimento involuntário que se impõe em meio ao "imaginar" como "seria" essa vontade, inicialmente com uma modalidade epistêmica que situa essa vontade de fazer força num plano imaginário, questionável, marcado tanto pela escolha lexical do verbo imaginar, quanto pelo uso do verbo ser no futuro do pretérito e pela interrogação. Imaginário esse interrompido subitamente por uma resposta curta e direta como o movimento involuntário que se impõe, "Física!", com ponto de exclamação, que marca o espanto dessa volta súbita do imaginário para o concreto real de "senti o corpo se contrair por vontade própria”. Lívia parece desenhar o movimento corpóreo e anímico com as palavras, de maneira tão didática que faz despertar a esperança de que seja lida, compreendida e aprendida, de que o poder da prática discursiva estabelecida possa de fato ser minada, de que palavras desnecessárias sejam poupadas nesse momento em que a mulher necessita silêncio e entrega ao involuntário que se lhe impõe.

E o último dos medos, o que seria a décima sexta ocorrência da palavra, em (55), não é um medo, é um "medinho" que a invade logo após o nascimento de seu filho, mas que também é desconstruído de imediato:

Senti uma alegria tão intensa, fiquei paralisada sorrindo e olhando pra ele. A placenta que ainda me dava um medinho... que placenta?? Ela nasceu e eu nem vi.

Com ele no colo, voltei para a maca e por ali ficamos por muito tempo. Eu olhando pra ele, ele dormindo e o Marcos chorando. Foi um momento em que o tempo parou.

Em (55), num fragmento extraído já da parte final do relato, Lívia mina discursivamente mais um medo possível, o medo do parto da placenta, o parto que sequer teria sido percebido. Esse momento corresponde à fase final do parto, após o nascimento do bebê, que tem início com as contrações, seguidas pelo período de expulsão do bebê. A placenta é um órgão gerado durante a gestação e que faz a "interface" entre a mulher e o feto, suprindo as necessidades fisiológicas do ser em formação, e sendo naturalmente expelido pouco depois do parto.

Ainda nesse fragmento, temos duas menções ao tempo, "por muito tempo" e "um momento em que o tempo parou". Essa possibilidade, de estar no pós-parto imediato, "por muito tempo", 
com o próprio bebê no colo e de gozar da sensação de que o tempo teria parado, poderia não ser tão relevante. Entretanto, diante de uma realidade em que muitas/os recém-nascidas/os são separados de suas mães logo após o nascimento para serem submetidos a procedimentos de rotina questionáveis, ou em que mães esperam por horas antes de finalmente poderem ver o rosto de suas/seus filhas/os pela primeira vez, muitas vezes numa espera solitária, proclamar essa possibilidade como algo real e vivido por ela mesma é um convite a outras mulheres para que reconheçam essa vivência como normalidade e não se contentem com menos.

Fechando seu relato, em (56), Lívia, como também fez Tânia, segue interpelando, por meio do testemunho de sua vivência e de suas reflexões, mais mulheres a acreditarem na experiência possível de um parto digno e respeitoso:

(56) Olho para trás e respiro aliviada todos os dias quando penso que sempre é tempo de mudar. Que basta ter coragem para conhecer o novo e mudar o ponto de vista. Que ter desconfiado de tantas certezas me fez renascer como mulher.

Ter parido da forma que eu queria fez de mim uma mulher realizada!

Embora modalize subjetivamente em (56), conferindo subjetividade a suas afirmações ao dizer "penso que", sua afirmação denota categoricamente a totalidade do tempo no advérbio "sempre", confere poder absoluto à "coragem de conhecer o novo" - que nós poderíamos na realidade dizer "retornar" ao velho, à tradição, pois a novidade é o parto medicalizado e cheio de intervenções, não o parto natural e fisiológico. A autora do relato convida, por meio da utilização de uma metáfora, do "renascer", ao renascimento possível quando se desconfia de certezas estabelecidas. Ao utilizar em uma mesma oração os conceitos de desconfiança e certeza, Lívia mais uma vez denormaliza, contribuindo para o abalo de estruturas de um sistema no qual as mulheres vêm sendo violentadas em nome de certezas tantas vezes questionáveis e sem fundamentação. É importante notar que, como em muitos dos chamados apaixonados e encantados, esta representação também traz consigo o risco de romantização e de essencialização feminina. Ao vincular a realização da mulher à experiência da maternidade, aqui especificamente à experiência do parto, pode-se estar reproduzindo também mais umas dessas mesmas certezas, cuja revisão se faz necessária.

\subsection{Algumas considerações.}

Como já foi dito antes, ao final das análises empreendidas deveríamos chegar a enunciados, evidenciá-los para enfim podermos submetê-los à crítica proposta. Esse é um dos grandes 
desafios analíticos da abordagem adotada, e a esse exercício passo a seguir. Ressalte-se que, embora busque agora explicitar os enunciados associáveis às análises aqui apresentadas, não chego até eles somente devido a essas duas análises - o que vale também para os que resultarem das análises das cartas a obstetras. A dedução desses enunciados é possível graças a toda a imersão temática evidenciada em minha posição discursiva, à macroanálise empreendida previamente e a outras análises finas realizadas tendo outros textos como corpus analítico (Regis, 2015; Regis \& Resende, 2015).

No que diz respeito especificamente à análise do relato de Tânia, ele é uma mostra de que estamos diante de uma virada discursiva, concretizada pela ocupação de posições estratégicas numa 'guerra de trincheiras', em termos gramscianos, por meio do estabelecimento de redes horizontais de solidariedade e de comunicação, de divulgação da possibilidade de nascimentos como eventos respeitosos, nos quais a mulher, sua família e a criança sejam protagonistas da história. Contudo, é importante perceber que há um interdiscurso no qual possibilidades discursivas contraditórias se encontram, mostrando a força das estruturas hegemônicas do discurso sobre a mulher e sobre o parto, mesmo em uma conjuntura marcada pela luta e a pela resistência libertária.

Mais especificamente, como resultado da análise do relato de Tânia, e em resposta às questões que norteiam este estudo, podemos dizer que, ela se identifica como vítima da violência obstétrica, por ter sofrido uma cesárea desnecessária no nascimento de sua primeira filha, mas também como capaz da superação que lhe permitiu 'curar a cicatriz', enfrentando vários obstáculos; como "deusa" e "Leoa" - numa perspectiva mística e animal sobre o parto -, e como ativista num movimento de mulheres, que conclama por meio do uso de imperativo e do "nós" inclusivo no trecho final do texto.

Em segundo lugar, sobre as/os profissionais da assistência obstétrica: são representadas/os de forma maniqueísta, em dois polos de oposição, com avaliação negativa do cesarista "fofo" e da G.O. que faz "terrorismo", além de diversas referências à violência obstétrica de modo geral, e avaliação positiva da enfermeira obstétrica que assistiu o nascimento de seu segundo filho; esses polos coincidem com a avaliação como inconfiável (“mentir para mim”) e confiável (“confio em vocês"). Por meio da descrição de intervenções conduzidas por sua equipe de atenção ao parto domiciliar, Tânia deixe entrever como mesmo profissionais confiáveis podem ter sido inculcados por aspectos do discurso hegemônico que pretendem descontruir, por 
exemplo pela visão do corpo feminino como sendo falho por natureza, carente de tutela e de intervenções de rotina para conseguir parir.

Ademais, sobre o contexto do pré-natal e do nascimento, o pré-natal é representado em duas perspectivas, a biológica e a da descoberta; neste segundo sentido, sendo frequentes as referências à busca por informações e a comunidades apoiadas nas novas tecnologias de comunicação, importa destacar as metáforas da descoberta ("despertar", "portinha para o universo") e a construção de um coletivo emancipador, de uma "rede de subjetividades" (Borges, Pinho \& Santos (2009, p. 378); o parto é representado no campo das possibilidades do instintivo, animal, do místico, espiritual e do feminino.

A representação do parto relaciona-se principalmente a discursos sobre violência obstétrica e sobre a superação dessa violência, com conquista de um "parto perfeito" e/ou a cura de cicatrizes colecionadas durante as violações sofridas; também ao discurso econômico, especialmente quando a autora questiona os interesses por trás das cesáreas desnecessárias e quais atores beneficiam-se do controle hospitalar sobre os processos fisiológicos do nascer (“profissionais 'interessados' na cesárea”); e a discursos sobre misticismo e instinto animal, na recorrência de metáforas da "deusa" e da "Leoa", no léxico do "transe".

A autora identifica-se explicitamente, em relação ao debate sobre parto e violência obstétrica, como ativista em defesa da autonomia da parturiente nas escolhas sobre seu parto e de seu protagonismo no evento do nascimento, especialmente ao final do relato, quando faz uso de verbos no imperativo e constrói um coletivo "nós". A seleção de relações intertextuais estabelecidas por meio de hiperlinks explicita o posicionamento da autora no debate, deixando ver as vozes que reconhece como autoridades no assunto. Em relação à perspectiva antagonista, aquela que promove o parto hospitalar, a autora mostra um reconhecimento da relevância da faceta discursiva da questão: "Eu vejo esse discurso (e vários outros) relacionados a um terrorismo da ideia do parto normal sendo feito não só pelos profissionais 'interessados' na cesárea, mas também pela mídia, por grandes meios de comunicação, por pessoas que reproduzem a fala do 'sistema"'.

A explicitação de estratégias persuasivas utilizadas por profissionais - como o "médico todo fofo" ou a "GO do postinho", nesse relato - que não assistem ou preferem não assistir parto normal, mas que se omitem em admiti-lo, construindo ao longo do pré-natal um quadro legitimador para a cirurgia, devido, quase sempre, à suposta incapacidade da mulher, que não estaria habilitada para um parto normal, pode servir de apoio a mulheres em busca de 
emancipação, instrumentando-as para se posicionar mais claramente diante de tais estratégias e estimulando-as a buscar outros indícios quanto à validade das afirmações feitas, a verificar, por exemplo, as estatísticas dos procedimentos realizados pela/o profissional e a cota de cirurgias em comparação ao número de partos normais assistidos.

Não podemos deixar de observar que, ao defender a irrestrita autonomia da parturiente no evento de seu parto, a escolha discursiva foi a ênfase no feminino ligado ao místico e ao instintivo, em oposição ao racional. Embora essa seja uma estratégia argumentativa, é de notar que pode ter um efeito dúbio, ao reconstruir a oposição em que a racionalidade é reservada ao masculino, ficando a mulher restringida ao sensorial e ao intuitivo. Essa separação, ao lado daquela que reduz o feminino ao privado e ao doméstico, tem sustentado sistemas de dominação, e sua reverberação nesse contexto pode conduzir à percepção do parto domiciliar como uma escolha pouco racional, o que certamente não é o objetivo desse relato de parto, mas poderia ser um efeito potencial das escolhas textuais aí empregadas.

Por outro lado, a evidenciação do dizível e do indizível, assim como o ecoar da desobediência aos limites discursivos impostos hegemonicamente, com a expansão das fronteiras e a nomeação das experiências vividas sem normalizações, mas sim com a escandalização (S. Jäger, 2012; M. Jäger, 1996) da violência existente, eventualmente mesmo num parto assistido em domicílio, também pode contribuir para a emancipação de outras mulheres e para a escandalização de toda uma situação de violência institucionalizada que tem sido normalizada.

Quanto ao relato de Lívia, um dos enunciados que podemos deduzir de sua análise é a vigência do pressuposto, da normalidade, do medo do parto na identificação da mulher que pare ou parirá, medo ao qual ela tenta se contrapor com seu relato, ao tempo em que ressalta outro medo sentido, especialmente entre as mulheres que almejam parir naturalmente, com o mínimo de intervenções possíveis: o medo de ser submetida (desnecessariamente) a uma cirurgia.

Outro enunciado, que diz respeito ao contexto da assistência obstétrica do país, equivaleria à afirmação: caso você não encontre a equipe, você provavelmente não conseguirá receber uma assistência que respeite seu protagonismo no momento do parto. Recorrente nos relatos, esse enunciado se marca no relato de Lívia pela menção à troca de médica e pelo alívio relatado, de quando encontrou a "equipe humanizada". O relato de Lívia deixa entrever, exemplarmente, a diversidade possível, exemplarmente, entre médicos (os "parteiros" e os outros). Sendo que os outros seriam a regra e "os parteiros", a luz no fim do túnel. 
Também poderíamos destacar como enunciado, relativo à identificação da mulher nesse contexto, a busca por uma alternativa diferente diante da assistência obstétrica atual, uma busca que não dispensa a técnica e a formação acadêmica, embora a deseje complementada pelas qualidades imaginadas de uma parteira tradicional. Vemos aqui um permear entre discursos, interdiscursividade, um enliçamento discursivo, para usar o termo de Margarete Jäger (1996), que defende que os distintos discursos e suas vertentes sempre se entrelaçam, influenciam, sustentam, e que seria interessante observar como participantes do discurso lidam com esse enliçamento, em parte também contribuindo, ou não, para sua constituição ou reprodução. Pois se é verdade que Lívia resiste, ela não renega por completo a medicalização vigente atualmente na assistência obstétrica, embora pareça concordar com Santos (2010, p. 181), que defende que “saberes da tradição oral, dentre os quais se encontram os das parteiras, embora rechaçados, são vistos como fenômenos sociais capazes de influenciar o paradigma e as práticas científicas da modernidade."

Outro enunciado, também relativo à identificação da mulher, diz respeito à existência de um anseio pela humanização da assistência obstétrica, para que essa assistência aconteça com serenidade, amor e respeito. E só se faz necessário falar dessa humanização porque ela não corresponde à normalidade. Portanto entendo que, embora o relato de Lívia refira-se a uma experiência positiva, de uma assistência "humanizada", ele todo pressupõe a excepcionalidade dessa experiência, o que tem como pano de fundo, como já mencionado anteriormente, os altos índices de violência obstétrica verificáveis no país. E com sua resistência viva na denormalização do medo, Lívia nos recorda Werner Fassbinder e a bela expressão que dá título a um de seus filmes “Angst essen Seele auf” - em um alemão truncado que poderia ser traduzido como "Os medos devoram a alma!"29.

Enfim, antes de passar à análise das cartas, gostaria de fazer uma consideração metodológica. Neste capítulo, realizei duas análises em formatos distintos. A primeira considerou o texto na íntegra, sem um recorte temático ou aspectual prévio. A segunda, realizada num recorte transversal, atendeu à condição de ter considerados fragmentos afetos à autoidentificação, o aspecto mais recorrente nos relatos. Ao cabo deste exercício, embora considere as duas formas válidas e profícuas, parece-me que o recorte transversal acaba gerando uma sensação de incompletude, justamente por excluir a possibilidade de uma discussão acerca de toda a

\footnotetext{
${ }^{29}$ Embora o título em português seja Todos nos Chamamos Alí.
} 
complexidade discursiva da qual só a análise integral parece dar conta. Também devido a isso sigo com a análise integral ao tratar das cartas no próximo capítulo. 


\section{CAPÍTULO 5 Análise fina. Cartas à/ao obstetra.}

Desejo de todo coração que essas palavras o façam refletir sobre a sua prática profissional. E também em suas condutas como ser humano. E se isso não acontecer, oro ardentemente a Deus para que nenhuma outra mulher prestes a parir, cruze o seu caminho. Que Deus as proteja!

(Flávia Cunha)

Como já procedemos com dois relatos de parto, submetendo-os à segunda etapa analítica, à análise fina ou microanálise, analisaremos agora duas cartas à/ao obstetra. A primeira será a carta de Elena, que escreveu a sua obstetra durante a segunda gestação, comentando e avaliando, negativamente, a assistência ao nascimento de sua primeira filha por meio de uma cesariana. E a segunda será a carta de Dandara, que após muito relutar em procurar um médico durante o pré-natal, devido a sua descrença nas/os profissionais e no sistema, acabou por encontrar um médico a quem agradece, por meio de sua carta, pelo atendimento recebido.

5.1. Análise fina da carta de Elena: "Daí você nasceu minha filha..."30

Elena é mãe de Lara, 7 anos, nascida por meio de uma cirurgia cesariana, e de Ernesto, nascido há 3 anos e meio em um parto domiciliar assistido por parteira. Ela escreveu a carta à obstetra que a atendera no pré-natal e nascimento de Lara, num processo de superação dos traumas resultantes da maneira como veio ao mundo sua primeira filha. Embora não fosse essa a ideia inicial, Elena acabou por enviar de fato a carta à obstetra, de quem nunca obteve resposta alguma. Elena, que se aproximou de mim para buscar informações sobre parteiras durante sua segunda gestação, foi convidada, após o parto, a participar da pesquisa cedendo seu relato de parto para análise e, voluntariamente, enviou-me também a carta que agora analiso, para o caso de o texto também poder ajudar no trabalho.

Após sua oferta para que incorporasse a carta à pesquisa, percebi que poderia abordar na pesquisa esse gênero discursivo híbrido, intermediário entre carta pessoal e correspondência comercial entre usuário/a e prestador/a de serviços de assistência obstétrica, e constatei que muitas mulheres têm redigido e enviado tais cartas a suas/seus obstetras, sobretudo para explicitar sua insatisfação com o serviço prestado, embora também tenha encontrado cartas

\footnotetext{
${ }^{30}$ Uma versão anterior desta análise foi publicada sob o título de "Daí você nasceu minha filha": análise discursiva crítica de uma carta ao obstetra" (Regis e Resende, 2015).
} 
elogiosas, com propósito de agradecimento, como a carta de Dandara, que também será analisada neste capítulo. Por isso, não só aceitei sua oferta/sugestão como resolvi incorporar outras Cartas ao Obstetra ao corpus da pesquisa.

A seguir, veremos como possibilidades distintas de representação são evocadas na carta ao obstetra escrita por Elena, e como essas representações específicas também ensejam estilos, ou formas de identificação, específicas - em termos de processos ligados a dilemas relativos ao nascimento. Para tanto, lançaremos mão de categorias analíticas ligadas à LSF e à ADC avaliação, modalidade, pressuposição, coesão, intensificação, ironia, metáfora.

Apresento então a carta de Elena dividida em excertos acompanhados da análise empreendida. A carta é apresentada e analisada na íntegra, mas para fins analíticos foi segmentada em 13 excertos, correspondentes a fases textuais identificadas como movimentos retóricos específicos. Como já disse, o texto em foco realiza um gênero híbrido entre a carta pessoal e a correspondência comercial afeta à prestação de serviços. Assim, os movimentos retóricos identificados estão entre a realização do formato carta, como saudação e despedida, e o esforço na tematização narrativa e argumentativa do serviço em questão, a assistência pré-natal e ao nascimento.

Os movimentos identificados e pelos quais o texto foi segmentado para análise incluem: saudação e reconhecimento da impertinência da carta; autoapresentação e recordação do passado em comum; avaliação do pré-natal; identificação do momento de determinação da cesárea; narrativa do nascimento; narrativa da hemorragia uma semana após o parto; narrativa da curetagem realizada duas semanas após o parto; narrativa dos dias seguintes à curetagem; argumentação sobre as consequências psicoemocionais da cesárea e de suas sequelas; acusação e questionamento dos procedimentos; tematização da nova gestação e das novas expectativas; encerramento e nova justificativa da impertinência da carta. Como veremos, em termos das sequências tipológicas, a carta é predominantemente narrativa, mas a narração serve à argumentação e à avaliação do serviço prestado pela obstetra.

Como é de se esperar, pelo hibridismo de gênero com a carta pessoal, a carta de Elena é escrita em primeira pessoa, portanto, predomina a modalidade subjetiva.Elena é não apenas o foco dos eventos narrados como é também a origem das sucessivas avaliações apresentadas. Por seu propósito catártico, texturizado inclusive ao final da carta como justificativa para sua produção e envio à médica, o texto constrói-se pelo tom emotivo e pela reminiscência da memória e do 
trauma. Como já disse em relação à modalidade, Fairclough (2003, p. 191) a retoma dentre as categorias analíticas discutidas por Halliday e a distingue em modalidades epistêmicas, relacionadas ao grau de comprometimento com a verdade do que se assevera; e modalidades deônticas, relacionadas ao grau de obrigatoriedade ou necessidade do que se propõe.

Vejamos, então, no início da carta de Elena, reproduzido em (57), a saudação, o vocativo e o reconhecimento da própria impertinência:

Olá Doutora Débora,

Eu sei que você é muito ocupada e provavelmente não tem tempo para ler cartas de ex-pacientes, mas mesmo assim escrevi, quem sabe bate uma curiosidade.

O vocativo é relevante para a função interpessoal e, portanto, para indagar os processos de identificação delineados nessa interação. De acordo com (Halliday, 2004, p. 134),

ao utilizar um vocativo, a/o falante está promovendo a participação da/o endereçada/o na troca. Isso pode servir para identificar uma pessoa em particular sendo interpelada, ou para chamar a atenção dessa pessoa; mas em muitos contextos dialógicos a função do vocativo é mais a negociabilidade: a/o falante se utiliza dele para marcar uma relação interpessoal, algumas vezes assim reivindicando maior status ou poder.

A seleção lexical realizada no vocativo, com anteposição do título profissional ao nome próprio, denota a atitude de distanciamento entre autora e endereçada, a manutenção da interação no âmbito do relacionamento entre paciente e médica, ou entre cliente e prestadora de serviços. Elena não reivindica maior status ou poder; contudo, realça a assimetria de poder entre ambas ao evocar a posição de "doutora” de Débora e, posteriormente, relembrar sua condição de expaciente, como também veremos adiante em (58). Assim, o vocativo aqui é um elemento que marca a apreciação da devida distância entre médica e ex-paciente.

Em (57), temos uma assertiva categórica afirmativa acompanhada de intensificador ${ }^{31}$ de qualidade, "muito ocupada". A negação modalizada com uma probabilidade média ("provavelmente") revela baixa expectativa quanto à obrigação de leitura. Em ambas as ocorrências, há avaliações inscritas que evocam uma identificação negativa de Dra. Débora, por parte de Elena, já que no nosso contexto de cultura uma médica ter um grande número de

31 Ver intensificação na seção 2.4.2.9. 
pacientes, ser muito ocupada e consequentemente não ter tempo para dar atenção a (ex-) pacientes não é algo apreciado, estimado socialmente. ${ }^{32}$

No início de sua carta, Elena já reconhece sua "ousadia”, o que ela realiza no mecanismo de coesão e na relação lógica que ativa em “mas mesmo assim”. A probabilidade de sua carta ser lida é modalizada como baixa, na decorrência lógica das avaliações cotejadas com "quem sabe bate uma curiosidade" - ativando um sentido irônico por meio da relação entre avaliações de falta de disponibilidade/impertinência da missiva, Elena sugere não acreditar que sua carta terá qualquer efeito, mas, independentemente disso, escreve. O sentido de escrever uma carta cujo ponto de partida é desde já não produzir eco na interlocutora é deixado por ora aberto, mas será tematizado ao final da carta, como veremos.

Na sequência da carta, no excerto reproduzido em (58), temos o momento da autoapresentação; na realidade, trata-se de uma recordação do passado de interação entre Elena e Dra. Débora, então sua obstetra, que se configura no afastamento autobiográfico entre o eu narradora e o eu naquele momento:

$$
\begin{aligned}
& \text { Provavelmente você não se lembra mais de mim, tendo em vista o grande } \\
& \text { número de pacientes que tem. Meu nome é Elena, fui sua paciente em 2009, } \\
& \text { quando tive minha primeira gestação e pretendia ter meu primeiro parto. } \\
& \text { Estava recém-chegada em Brasília, em uma situação um pouco difícil, com } \\
& \text { meu marido morando em outro Estado e uma gravidez não esperada, mas } \\
& \text { desejada. Fiz meu pré-natal com você, já que uma amiga que tinha o mesmo } \\
& \text { plano de saúde e estava grávida me disse que era uma das médicas que estava } \\
& \text { em uma tal lista de obstetras que faziam partos normais. Como eu queria ter } \\
& \text { um parto normal, comecei minhas consultas. }
\end{aligned}
$$

Nesse excerto, a suspeita levantada com relação ao esquecimento da médica e a relação causal estabelecida - por meio da expressão "tendo em vista" - com a quantidade de pacientes de Dra. Débora retomam a avaliação crítica não só da obstetra em si, mas de uma característica relativa a um modelo de assistência médica estruturado de forma a tolerar que profissionais da área trabalhem em um esquema que compromete a qualidade da atenção. Sobre isso, Patah \& Malik (2011, p. 191), fazendo menção a Hotimsky (2002), escrevem que

a sobrecarga na jornada de trabalho do/a obstetra, que inclui atividades em consultório particular, plantão em hospitais públicos, atendimento ao parto em hospitais privados e, às vezes, atividades de ensino e pesquisa, faz com que esse/a profissional não disponibilize seu tempo para aguardar o trabalho de

32 Ver mais sobre essa categoria na seção 2.4 .2 , no subitem referente à avaliação. 
parto, favorecendo a decisão pela cesariana.

Embora esses sentidos não estejam explicitamente texturizados na carta, são evocados aqui, e também no excerto anterior. Nesse excerto em (58), outra relação causal - marcada pelo conector "já que" - é selecionada para justificar a opção pelo pré-natal com Dra. Débora, e não com outra/o obstetra qualquer: a dependência do plano de saúde e de recursos humanos escassos na atual conjuntura, ou seja, obstetras que assistam partos normais. Cotejada a justificativa para a escolha da médica - nas orações iniciadas por "já que" e por "como" - com o desejo não concretizado de parir, evocado no uso do pretérito em "queria" e "pretendia", e com a modalidade epistêmica baixa, de claro afastamento, presente em "uma tal lista", as dificuldades de mulheres que buscam ter partos normais na rede privada de atenção médica no país ("plano de saúde") é posta em evidência, e é um enunciado recorrente entre as colaboradoras desta pesquisa.

Nesse excerto em (58), também está evocado o discurso associado a movimentos pró parto natural, nos quais acontecem disputas pelas definições no campo lexical da parturição, especificamente sobre a adequação ou não da denominação ‘parto' para o evento de nascimento por meio de uma cirurgia cesariana, que não corresponderia a um parto propriamente. Como Lara nasceu (ou foi nascida, na percepção de Elena - veja a seguir) por meio de uma cirurgia, aqui temos o pressuposto de que, apesar de suas pretensões (explicitamente texturizadas no pretérito, que implica aqui desejo não realizado), Elena não pariu - o que ela traz ao texto, por ativação de pressuposto ${ }^{33}$, é que ela não teria tido um parto: "pretendia ter meu primeiro parto".

No fragmento em (59), a seguir, Elena realiza uma avaliação do pré-natal:

Sempre que eu tentava falar sobre o parto você respondia rapidamente minhas perguntas e não dava muita atenção. Eu ficava um pouco desapontada com isso, mas como confiava que quando chegasse a hora meu corpo ia funcionar e eu ia parir, não dei muita importância.

Apesar do desejo pelo parto natural, a locução verbal "tentar falar" ativa a pressuposição de que o diálogo sobre esse assunto não se concretizou, limitando-se a tentativas por parte de Elena e a respostas furtivas e pouco atentas por parte da Dra. Débora. Com essa seleção, a autora da

\footnotetext{
${ }^{33}$ Fairclough (2001, p. 155) define pressuposições como "proposições tomadas pelo produtor [ou pela produtora] do texto como já estabelecidas ou 'dadas"” (acréscimo nosso), que podem ser engatilhadas por diversos recursos linguísticos, neste caso, pelo tempo verbal.
} 
carta representa a incongruência entre expectativas e recomendações e a atitude da médica, o que prenuncia, ainda que em baixo tom, a avaliação negativa a que conduz o texto da carta.

Ao mesmo tempo, Elena apresenta uma justificativa pela decisão de seguir o pré-natal, marcada também pela modalização atenuante do desapontamento e reforçada por uma autoidentificação positiva, inscrita na representação de si mesma - "meu corpo" e "eu" - em assertivas hipotéticas de futuro quanto a "funcionar" e "parir". Entretanto, se atentarmos para o tempo verbal composto ("meu corpo ia funcionar" e "eu ia parir"), que ativa o pressuposto de que "não funcionou' e 'não pariu', atrelado a "mas como [eu] confiava", começamos a ver o movimento de tessitura dessa carta: o movimento entre a responsabilização da médica e a culpa que Elena se impõe, e que tenta expurgar.

No excerto em (60), a seguir, Elena continua sua avaliação do pré-natal, agora com relação a suas últimas semanas:

(60) O tempo foi passando e quando cheguei nas 39 semanas você me falou que achava que a gravidez não deveria passar das 40 semanas, porque a placenta poderia não funcionar mais como deveria... Eu achei estranho, pois havia lido em vários lugares que a gestação poderia durar até 42 semanas, mas também não dei muita importância. Estava tudo absolutamente perfeito comigo e com a minha filha. A minha pressão era ótima, eu me exercitei a gravidez inteira, ganhei apenas 9 quilos, a posição da bebê estava perfeita, só "ainda um pouco alta", não havia circular de cordão, eu não tinha edemas, nada! Daí você começou a mandar eu fazer um monte de ecografias e até um exame complicado que eu tive o maior trabalho para achar onde fizesse e a liberação do plano de saúde. Mas então, na véspera de eu completar 40 semanas, às $6 \mathrm{~h}$ da manhã percebi que minha bolsa havia rompido. Saia muito pouco líquido, que era cristalino. Eu liguei pra você, me falou para ir ao seu consultório às $8 \mathrm{~h}$, já que estava indo fazer uma cesárea naquele momento. Eu fiquei muito animada, tomei um café da manhã bem reforçado, tomei um banho e fui ao consultório. Meu marido nem preparou nenhuma mala nem nada, já que sabíamos que as coisas ainda iam demorar, afinal eu ainda não tinha tido nenhuma contração.

Em (60), há presença de um discurso medicalizante e intervencionista, que focaliza os riscos e não as chances do nascimento. Um dos indícios da força desse discurso pode ser a reação de obstetras, quando consultadas/os sobre a possibilidade de atender a parto normal, com a clássica resposta: "Claro! Se estiver mesmo tudo bem!”. E mesmo na autoavaliação positiva veem-se as marcas desse discurso medicalizante, que impõe inúmeras condições e empenhos às mulheres que querem parir, como, por exemplo, se dedicar a uma atividade desportiva, sem os quais sua capacidade de parir estaria comprometida. Mais uma vez, o enunciado a que se chega corresponde à "visão pessimista sobre o corpo da mulher". 
Com relação às expectativas atendidas, o fragmento também mostra intensificação, tanto no epíteto "inteira", que reforça frequência e continuidade dos exercícios durante a gravidez, quanto no grau da animação, "muito animada". Também na repetida negação, com "não", "não", "nada", "nem”, "nenhuma”, "nem”, "nada”, "não", "nenhuma”, há intensificação. Percebe-se aqui representada uma convicção com relação à própria capacidade de parir e à boa condição física, numa autoidentificação positiva pressuposta, e também uma representação afetiva positiva em relação à possível chegada do momento do parto, entendido como um momento de júbilo, a apreciação do parto. Tudo isso serve, no fragmento, para justificar o fato de não ter dado "muita importância" ao comentário "estranho" da médica. No movimento mencionado anteriormente, Elena toma para si a responsabilidade pelo que lhe aconteceu ("não dei muita importância”), mas mitiga essa responsabilidade pelas justificativas apresentadas.

No excerto seguinte, em (61), Elena trata do momento em que houve a determinação da cesárea:

(61) Quando chegamos ao seu consultório, você me recebeu muito bem, pediu para eu tirar a roupa e fez o toque. Constatou então que eu não tinha nenhuma dilatação e, como o neném estava muito alto e eu não tinha nenhuma contração, disse que teria que ser uma cesárea, naquele momento. Eu perguntei se não dava para induzir, e você disse que não tinha jeito e me mandou direto para o hospital. Eu obedeci. Fiquei lá deitada na cama, me movimentando muito pouco com medo de perder líquido e meu bebê sofrer alguma coisa. Quando chegaram as enfermeiras com uma maca para me levar até o centro obstétrico, eu pedi para ir ao banheiro antes. Nesse momento, meu tampão saiu de uma só vez. Eu achei que fossem algumas "melecas" que estavam saindo do meu útero, e me convenci de que realmente tinha que fazer logo essa cesárea, antes que o quadro piorasse! E foi assim.

Nesse trecho, há de início uma aparente identificação positiva da médica, que a recebeu "muito bem". Contudo, sabe-se que entre ativistas contra a violência obstétrica é recorrente a menção à/ao ginecologista obstetra “fofo", como identificado também por Tânia em seu relato. Por isso entendemos que a representação positiva de Dra. Débora tem, na carta em questão, sobretudo a função de construir esse recorrente estilo de "cesarista boazinha". Na representação em tela, a negação reforçada, "nenhuma dilatação", e a apreciação negativa tanto da situação do bebê, "muito alto", quanto das condições fisiológicas de Elena àquela altura, "nenhuma dilatação" e "nenhuma contração" seriam as seleções que evocam a responsabilidade de Elena, ou de seu corpo, para justificar a necessidade de uma cesárea naquele momento. Em relação ao movimento, antes mencionado, entre a responsabilidade da médica e o peso da própria culpa, temos aí um caso de texturização de estima social, no caso negativa, com relação a sua 
capacidade de parir, sem contudo deixar de ser aludida a figura da "cesarista gente boa", caso entendido não como questão de estima, mas sim de sanção social (Martin e White, 2005).

Se em (61), com "muito bem", teríamos um julgamento, atualizando uma identificação positiva da médica, considerada a antecipação indevida do nascimento numa conjuntura em que mesmo os contestáveis argumentos característicos do discurso intervencionista medicalizante, que muitas vezes buscam justificar uma cesárea, não se aplicariam, por estar tudo "absolutamente perfeito" - pressão, exercícios, peso, posição, cordão -, Elena apresenta sim um julgamento pressuposto negativo quanto à honestidade da médica, que realizou a cesárea como se fosse de emergência. Essa aparente contradição entre elogio e crítica é esclarecida na ironia com que tem início o próximo trecho, em (62):

Fiquei lá no centro obstétrico um tempo te esperando, acho que você tentou atender todas as pacientes da manhã antes de ter que sair do consultório pra fazer essa cesárea de emergência. Daí você nasceu minha filha, eu passei um pouco mal durante a cirurgia, não sei bem o que aconteceu, acho que quase desmaiei, fiquei lá parada, deixando as coisas acontecerem. Depois escutei o choro da minha filha, foi o momento menos ruim. Depois nem lembro quem me trouxe ela e encostou na minha bochecha e queria que eu beijasse ela. Eu olhei e obedeci, só porque me mandaram. Depois levaram ela embora e você e outra pessoa (acho que era um médico) ficaram me costurando. Bem normal, né? Do jeito que você está acostumada.

Mencionando o atendimento de "todas as pacientes da manhã" antes de "fazer essa cesárea de emergência”, Elena questiona ironicamente a convicção da própria médica com relação à urgência da cirurgia, posta em questão pela manutenção da agenda. Tanto essa atitude, quanto o fato de a médica ter-lhe 'nascido' a filha, tudo isso a que Dra. Débora "está acostumada" é alvo da ironia de Elena, quando conclui o trecho questionando: "Bem normal, né?". Essa ironia é indício da virada no tom da carta, fazendo um contraponto à representação do apassivamento de Elena, que ou "estava lá parada, deixando as coisas acontecerem", ou olhando e obedecendo “só porque [...] mandaram". Aumentando o volume e mudando o tom, Elena intensifica a crítica e aumenta também o peso da responsabilidade de Dra. Débora pelo acontecido, apesar de sua própria passividade diante dos fatos.

Por meio de modalidades epistêmicas baixas, no trecho em (62), Elena sugere incerteza sobre o que lhe aconteceu - "acho que”, "não sei bem”, “acho que”. Esse sentido se reforça pela reação passiva por meio da qual ela se autorrepresenta - inclusive contrariando expectativas de alta estima social relativas ao nascimento, normalmente marcado pelo primeiro choro do bebê e pelo primeiro encontro emocionado e afetivo entre mãe e filha, suspendendo, como num passe 
de mágica, os efeitos das dores, naturais ou impostas, sentidas durante o nascimento. Com Elena foi diferente, "alguém" queria que ela beijasse a filha e ela obedeceu "só porque [...] mandaram”, e não por ímpeto próprio. Aí há mais julgamento evocado, agora quanto à normalidade, ao que seria o usual, pois a negação vai de encontro ao que se espera culturalmente do momento em que uma mãe veja pela primeira vez seu bebê, e daí deriva uma autoavaliação negativa pressuposta, por ter beijado a filha só porque mandaram, por não querer de verdade fazer isso, o que não seria algo "normal". Mas há, ao mesmo tempo, uma desconstrução discursiva denormalizadora de uma suposta essência feminina romantizada no tocante à maternidade.

Em (63), reproduzimos a passagem que relata o mal-estar que se seguia ainda uma semana após o parto:

(63) Uma semana após o parto eu tive uma hemorragia. Eu passei muito mal. No dia seguinte, quando fui ao seu consultório, você comentou que a cesárea é uma cirurgia um pouco grande, que de fato você havia tido uma dificuldade em conter um sangramento quando tirou a placenta. Depois falou que, sabe como é, é tanta coisa, às vezes pode ter ficado uma gaze no meu útero. Me deixou um pedido de ecografia, mas para eu fazer só caso a situação piorasse. Me mandou tomar ferro no pronto socorro do hospital, com uma neném de uma semana, já que eu estava anêmica. E eu obedeci.

A informação temporal, "uma semana após o parto", em (63), faz parte da representação de uma sequência semanal de eventos - 39a semana e 'preocupação' com a falência da placenta, cesárea 'emergencial' na 40ª semana, hemorragia uma semana após o parto e curetagem uma semana depois disso (no excerto a seguir) - que demonstra, com intensidade cada vez maior, a tendência cesarista e a desonestidade pressuposta da médica, representada de forma correspondente ao estilo da 'cesarista fofa', já mencionado. Ainda nesse excerto, aparece, por mais de uma vez, a representação da voz da médica nos verbos dicendi - "você comentou", "falou", "me mandou". Elena atribui modalidade epistêmica baixa a essa voz em relação ao conteúdo que expressa: “às vezes”, que aqui corresponde a 'talvez', e "sabe como é”, expressão de oralidade que também denota incerteza. Assim, a competência da doutora é sutilmente posta em dúvida.

A passagem em (64) representa mais uma fase dessa sequência semanal e trata da semana após a hemorragia, em que Elena precisou se submeter a uma curetagem:

(64) Uma semana depois disso, eu me sentindo muito fraca, comecei a ter muitas 
cólica, e uma coisa podre e fedorenta começou a sair de mim. Daí eu te liguei e finalmente fui fazer a ecografia. Havia muita coisa dentro de mim, meu útero estava crescendo novamente. Você olhou o exame e falou que teria que fazer uma curetagem à noite. Ainda estávamos na hora do almoço. Eu tinha uma neném recém nascida e muita dor e coisas fedorentas saindo de dentro de mim. Nós estávamos no hospital, mas você tinha muitas pacientes para atender, né? Então eu fui pra minha casa, em Sobradinho, pra voltar a noite. Eu teria que dormir no hospital para me recuperar da anestesia, já que a cirurgia seria feita a noite. E eu obedeci.

Mais uma vez, em (64), "muito fraca", “muitas cólicas”, “muita coisa”, “muita dor”, "muitas pacientes" são reforçadores, nos termos de Pardo (2011), que realizam intensificação por meio de repetição, nos termos de Martin \& White (2005), do que se interpreta como uma autoidentificação negativa com relação àquele momento - fraqueza, dor, muita coisa indesejada dentro de si - e uma alteridentificação negativa, mais uma vez pelo grande número de pacientes - outra repetição, portanto amplificação, no desenrolar da mensagem.

Ademais, há paralelismo tanto na ironia com relação ao dia da cesárea "de emergência", quando a agenda do consultório foi mantida -"mas você tinha muitas pacientes para atender, né?" quanto no tópico das passagens, "uma semana após o parto" e agora "uma semana depois disso", finalizadas ambas com a confissão "e eu obedeci”. Outro paralelismo está na modalidade de obrigação "teria que", verificada pela segunda vez na carta, agora com respeito à curetagem, e antes referente à cesárea. Essa organização textual também tem o efeito amplificador, quando o texto se assemelha a ondas concêntricas como as resultantes de uma pedra atirada em água parada, que reverbera em crescente amplitude, como o que acontece aqui com o tom de acusação na carta de Elena.

A mensagem continua em (65), comentando o dia da curetagem e se referindo às consequências disso no conceito que fazia então de si mesma e de seu corpo:

Passei muito mal naquele dia. Você atrasou muito pra chegar e tirou tanta coisa podre de dentro de mim que mandou ficar internada três dias tomando antibiótico. E eu fiquei lá, com minha neném no meio dos doentes internados. Você não me explicou o que afinal de contas tinha dentro de mim, porque aquilo aconteceu. $\mathrm{E}$ eu fiquei muito grata, afinal, você foi muito atenciosa e estava muito preocupada comigo. E eu me sentia muito mal porque fui incapaz de parir, e ainda tive uma complicação que reforçava ainda mais a incapacidade do meu corpo em parir e lidar com a gravidez.

Em (65), num processo identificativo, o 'eu' de Elena ocupa o maior espaço - "passei muito mal”, "dentro de mim", "e eu fiquei lá", "e eu fiquei muito grata", "e eu me sentia", "e ainda tive", "meu corpo" -, embora a representação de Dra. Débora esteja também presente, alvo 
de avaliação explicitamente negativa - muito atrasada, sem dar explicações -, mas também 'pseudopositiva', ainda no estilo irônico que perpassa a carta - "muito atenciosa", "muito preocupada".

Quanto a sua própria identidade à altura, seleções como "muito mal", "tanta coisa podre", "muito grata", "incapaz", "incapacidade” expressam seu mal-estar e a imagem negativa que pintava de si mesma, tanto no que diz respeito à suposta incapacidade para parir, quanto no que se refere a sua incapacidade de compreender que essa incapacidade não fosse senão forjada, como agora reconhece.

A avaliação negativa que Elena expressa sobre si mesma corresponde à crença de outras mulheres em contextos semelhantes, à crença na própria incapacidade para o parto. Conforme estudos realizados no âmbito do Projeto Nascimento e Parto: normal, naturalmente..., muitas mulheres acreditam ter sido submetidas a cesáreas por falhas intrínsecas a seu próprio organismo, o que as impediria de ter um parto vaginal. Essa visão "pessimista", característica do discurso biomédico, "estaria sendo reelaborada por elas, como um discurso que diz respeito intrinsecamente ao funcionamento de seus próprios corpos" (Homtsky et al. 2002, p. 1309).

Embora Elena de certa forma se ridicularize pela gratidão que agora avalia indevida, a representação da médica em (65) serve como atenuante dessa autoidentificação negativa, pois sua postura teria sido provavelmente distinta caso a médica tivesse sido transparente e coerente em suas ações verbais e não verbais desde o início do pré-natal. Na identificação da médica, muito atrasada, mas ainda assim "muito preocupada" e "muito atenciosa", há um contraste que denota, de alguma maneira, a incoerência na imagem que podemos fazer dela, entre negligente e cuidadosa, texturizando um estilo correspondente mais uma vez à figura da 'cesarista fofa'.

Até a esta altura, a carta de Elena representa, em primeiro plano, o exercício de poder pela obstetra, conduzindo a processos identificacionais negativos, denegando à mulher suas potencialidades. Isso se alinha com o que concluiu Izabel Magalhães, em seu livro Eu e tu (2000, p. 125), que trata da "constituição do sujeito no discurso médico", sobre os efeitos de poder da consulta médica, que frequentemente resultam na imposição de uma identificação negativa às mulheres.

No próximo excerto da carta, em (66), Elena expõe as consequências psicoemocionais do ocorrido, sua avaliação sobre o comportamento de Dra. Débora e a necessidade de que a médica tome conhecimento delas: 
Depois que tudo isso passou, meu sentimento de incapacidade de parir foi
sendo substituído por culpa de não ter me informado o suficiente para tomar
as atitudes corretas que me permitiriam parir e um vazio muito grande por isso
não ter acontecido. Achei muito desonesto de sua parte não ter simplesmente
me informado que você prefere fazer cesáreas e que não ia se esforçar para
que eu tivesse o parto que queria, muito pelo contrário. Gostaria que você
soubesse que isso causou um transtorno muito grande na minha vida, que
penso nisso quase todos os dias e que era muito importante para mim ter meu
parto e para a minha filha passar pelo trabalho de parto e nascer naturalmente.

Em (66), temos a expressão explícita de que por fim, "depois que tudo isso passou”, num movimento retórico de página virada, o sentimento de incapacidade se atenuava, sem contudo suprimir a autorresponsabilização de Elena pelo parto que não viveu. Sua incapacidade é apenas transferida do plano corporal ou fisiológico para o moral atitudinal. Elena se sente culpada por não ter se "informado o suficiente para tomar as atitudes corretas que [lhe] permitiriam parir", e daí decorre também um "vazio", uma lacuna, devido ao que se tem chamado 'parto roubado', nas palavras de Carvalho (2014), "um conceito político de resistência”.

Desse vazio, Elena parte para o julgamento explícito, ainda que modalizado pelo processo mental achar - "achei muito desonesto de sua parte" -, quanto à propriedade de Dra. Débora, pelo fato de não agir de acordo com suas obrigações ético-profissionais, por ser desonesta, um caso para sanção social. Também seria objeto de sanção social o fato de Dra. Débora não se esforçar para que Elena parisse naturalmente, sendo o parto natural o melhor para a saúde da mãe e do bebê. Conforme estudos realizados por grupos de trabalho da OMS, comentados exemplarmente pela médica, pesquisadora e ativista Melania Amorim (2012), qualquer cesariana, com ou sem indicação, estaria associada ao aumento de risco de "desfechos perinatais graves: morte perinatal, morte fetal, morte neonatal precoce, hospitalização em UTI neonatal por mais de sete dias e complicações perinatais graves”. A representação na carta de Elena traz à tona as complicações de sua cesárea, que causou "transtorno muito grande", numa seleção em que se espraia a negatividade, intrínseca ao item lexical "transtorno" e amplificada pelos qualificadores “muito" e "grande". Elena remete não somente às complicações materializadas como também àquelas atinentes ao potencial que não se concretizou, quando foi impedida de viver algo que era "muito importante", quando teve enfim seu parto roubado.

Entretanto, mesmo diante do ocorrido, Elena ergue a cabeça num processo emancipatório e redige - e envia! - essa carta. Ao fazer isso, verbaliza, explicita seu julgamento com relação à médica, que escolheu precisamente por estar "em uma tal lista de obstetras que faziam partos normais" - ver (58) - e se levanta contra a violência a que foi submetida. Ao fazê-lo, coloca-se 
como conhecedora - "Gostaria que você soubesse" -, o que, por um lado, expressa certeza de seu julgamento e, por outro, coloca em dúvida as certezas atribuídas à médica.

Em (67), a seguir, Elena representa sua visão atual dos fatos até agora narrados, reforça sua acusação e levanta questionamentos sobre tudo o que aconteceu, numa típica estratégica autobiográfica, a marcação enfática da diferença entre a identificação do eu narrador e a do eu narrado, localizado no passado, na introdução "Hoje sei...":

(67) Hoje sei os motivos que levam um médico a inventar qualquer desculpa para fazer uma cesárea e isso é ainda pior de se saber. Não é ético. Até hoje não sei os reais motivos da complicação que tive após o parto. Foi outra falha sua, não foi honesta para me contar o que aconteceu. Simplesmente disse que "acontece". E eu sei que não acontece! Será que foi a gaze que você esqueceu dentro de mim? Será que você arrancou a placenta, que, depois das 40 semanas é tão "fraca" em nutrir o bebê que até gera uma hemorragia, de tão ligada que ainda estava à minha circulação?

Com o marcador temporal "Hoje", Elena marca, em (67), mais uma virada, atualizando uma autoidentificação positiva categórica de alguém que sabe - "eu sei", "eu sei” - o que precisa saber sobre "os motivos que levam um médico a inventar qualquer desculpa para fazer uma cesárea". E o julgamento segue com uma negação categórica, num alto comprometimento com o dito: "Não é ético". Elena reforça a avaliação, sem, contudo, incluir a médica e seu procedimento diretamente nessa assertiva. Mas os questionamentos que seguem, iniciados ambos com "Será", levantam mais uma vez a possibilidade de a falta de ética se aplicar sim às atitudes de Dra. Débora - não por ter possivelmente esquecido a gaze dentro de Elena, mas por não ter explicado o que realmente aconteceu.

O segundo "Será" levanta a uma vez duas suspeitas; primeiro, fazendo ironicamente uma alusão ao comentário da obstetra às 39 semanas, quando teria dito que após a $40^{\text {a }}$ semana "a placenta poderia não funcionar mais como deveria", e levantando ademais suspeita quanto à qualidade da cirurgia realizada, do que resultaria, entre outros problemas, a hemorragia sofrida. Temos aqui uma avaliação evocada, no que diz respeito à veracidade e também à propriedade da médica para a realização da cirurgia. Propriedade porque a profissional é identificada aqui como desatenta no exercício de suas funções - "a gaze que você esqueceu dentro de mim" - e veracidade por ser leviana na comunicação com seus pacientes, por instigar o medo e promover o risco. O pressuposto aqui é que levar Elena a acreditar que sua placenta era "fraca" não passaria de um ardil de Dra. Débora para conduzi-la ao procedimento de sua preferência, a 
cesárea, o que remete ao início do mesmo excerto, quando Elena sugere uma possível invenção de "qualquer desculpa" para realizar uma cirurgia.

As quatro negações, em (67), "não é ético", "não sei”, "não foi honesta" e "não acontece", expressam igualmente o teor digno de sanção social, pois todos esses nãos amplificam, essa repetição ecoa uma reprovação do estilo cesarista fofa, aquela que não age de maneira ética, que não promove um diálogo transparente e sincero com as mulheres que acompanha, que age com desonestidade e que expõe a mulher a riscos desnecessários, colocando seus próprios interesses em primeiro plano, como lobo em pele de cordeiro.

Com mais uma repetição, "Hoje", em (68), Elena menciona novamente seus saberes, a nova gestação e suas expectativas:

Hoje estou grávida de novo e sei como fazer para passar novamente por uma cesárea apenas se for necessário. E sei quais são as indicações para isso e das baixíssimas probabilidades de acontecerem.

As duas ocorrências de "sei" nesse trecho da carta se somam àquelas do excerto anterior, caracterizando também aqui tanto a repetição que amplifica os termos de sua missiva, quanto o pressuposto de que Elena continua se responsabilizando pela cesárea "de emergência" a que foi submetida. Se "hoje" sabe "como fazer para passar novamente por uma cesárea apenas se for necessário" e "quais são as indicações para isso e das baixíssimas probabilidades de acontecerem", subentende-se que outrora não sabia e que a "culpa de não ter [se] informado o suficiente para tomar as atitudes corretas que [lhe] permitiriam parir" persiste. Em mais um momento de autoidentificação, continua nessa passagem a oscilação constante na mensagem, em que Elena, numa tendência retórica cíclica, atribui a responsabilidade pelo que sofreu à obstetra, mas sempre intercalando aí a representação da culpa que ainda parece assumir.

Finalizando a carta, em (69), Elena demonstra mais uma vez a necessidade de justificar sua missiva, deixando pressuposta sua impertinência, mas concluindo em alto e bom som, para seguirmos com a metáfora do volume, com os objetivos de seu escrito:

(69) Escrevi esta carta para tentar me limpar um pouco do que aconteceu há dois anos e meio atrás para me libertar para conseguir parir dessa vez. Naquela época eu tinha certeza que era capaz de parir. Você me tirou essa certeza, que estou tentando recuperar. Escrevo também para que você saiba das consequências do que fez para mim e provavelmente para outras mulheres também. Quem sabe você poderia até manter sua conduta, porém sendo mais honesta, avisando as pacientes das suas práticas, para aquelas que ainda não 
estão bem informadas possam ter a opção de tomar outro caminho a tempo. Elena Campoflores elena_xx@xxxxx.com

As modalizações com "tentar" e "um pouco", em "tentar me limpar um pouco", e também em "tentando recuperar", e as metáforas com "limpar" e "libertar", implicam a identificação de Elena como alguém que se sente não só culpada, mas igualmente suja e presa a um passado, "naquela época" quando, embora tivesse certeza de sua capacidade para parir, não pariu. Ao afirmar que quer "conseguir parir dessa vez", relembra que foi a médica quem lhe 'nasceu' a filha, e com isso reflete seu posicionamento perante à mencionada disputa discursiva pelo poder simbólico, pelo que pode ou deve significar a palavra 'parto'. Nesse contexto de mudança, luta hegemônica, mobilização e reação, alguns grupos de mulheres negam à cesárea o status de parto - "Cesárea não é parto!" -, e outras as contradizem com um sonoro "Cesárea é parto sim!".

Com relação à Dra. Débora, Elena a julga deixando entrever a dúvida quanto à normalidade de sua conduta, de seu estilo cesarista, para a estima social, fazendo, entretanto, uma concessão modalizada - "quem sabe" e "poderia" - à manutenção de sua conduta, o que não prevê a negação da sanção social à desonestidade, pois a honestidade seria a condição para a concessão feita. Com sua carta, explicitamente na passagem em (69), Elena se levanta não somente por sua superação do ocorrido; ela se une a um movimento maior em prol de um atendimento digno não só para ela, mas "para outras mulheres também", levantando a suspeita de que o comportamento de Dra. Débora seja recorrente e que atinja também "outras mulheres", especialmente "aquelas que ainda não estão bem informadas" e que seriam vítimas da desonestidade da médica, que lhes rouba o direito de "opção" e com isso também o parto.

Assim, se Elena menciona mais uma vez a falta de informação, nesse momento final, ela se despe da culpa, reconhecendo não ter tido como "tomar outro caminho a tempo". Ao apontar o fator tempo, Elena deixa pressuposta também a justificativa para sua passividade em torno do momento do nascimento, momento em que a mulher, apesar de toda sua potencialidade, também está vulnerável. Embora essa vulnerabilidade não deva ser confundida com fraqueza, o momento do parto - com a bolsa rota, o medo que pode estar envolvido, a insegurança quanto ao bem-estar do bebê, a inexperiência - definitivamente não é o melhor momento para "tomar outro caminho".

Em relação à materialização do gênero carta, note-se ao final do texto uma pequena subversão: Elena não elabora uma fórmula de despedida, nem mesmo um frio 'cordialmente', que poderia 
ser de esperar. Isso também pode ser interpretado como parte do movimento que vimos discutindo, e do crescendo no qual a crítica se desenvolve: Elena inicia sua carta com um vocativo esperado, mas seu tom vai se elevando, e ao final parece já não haver espaço para cordialidades. E se, no início da carta, Elena deixa entrever pouca ou nenhuma expectativa quanto à leitura de seu texto, o endereço eletrônico registrado ao lado de sua assinatura, no fechamento da carta, indica outra esperança. Além de ser lida, Elena demonstra mesmo aventar a possibilidade de receber uma resposta da médica, que como já foi dito nunca reagiu à missiva de sua ex-paciente.

5.2. Análise fina da carta de Dandara: "Senti a necessidade de compartilhar aqui meus sentimentos".

Sigo agora para a análise da carta de Dandara, na qual agradece ao médico que a assistiu durante o parto. Como escrevi no capítulo dedicado à Análise Estrutural, Dandara divulgou sua carta ao obstetra em seu blog pessoal em 2014, onde se apresenta como mãe em dedicação exclusiva a seus três filhos, de 10, 3 e 1 ano - o primeiro nascido, segundo ela, de um parto normal hospitalar Frank; o segundo, de um parto hospitalar humanizado sem nenhuma intervenção, e o terceiro nascido de parto domiciliar. Sua carta foi selecionada para a microanálise pelo fato de ser representativa dos enunciados resultantes da Análise Estrutural, mas também por ser, diferentemente de todas as demais a que tive acesso, uma carta elogiosa, na qual é expressa a gratidão pela atuação profissional do médico. Assim, também "para não dizer que não falei das flores", resolvi selecionar este documento nesta etapa do processo analítico.

Da mesma maneira como procedi na análise da carta de Elena, segmentei a carta de Dandara conforme os movimentos retóricos identificados: saudação e justificativa da missiva; representação da dificuldade em aceitar procurar um/a médica/o; representação da imagem que fazia da/o profissional e do sistema de atenção obstétrica; lamento em relação a essas imagens; representação da imagem da/o profissional da pediatria neonatal; reforço da relutância em procurar um/a obstetra e justificativa para tê-lo feito; representação inicial da gratidão ao médico; mudança de perspectiva da permissão para o respeito; expectativa com relação à reação do médico diante de suas palavras; imagem final sobre o médico e seu papel durante o parto.

Passemos então aos fragmentos e a sua análise, a começar pelo fragmento em (70): 
Senti a necessidade de compartilhar aqui meus sentimentos em relação ao meu parto.

Correspondente ao gênero carta, Dandara também inicia sua carta com um vocativo, no qual, além do "título" profissional, ela inscreve nome e primeiro sobrenome do médico. Como na carta de Elena, a seleção lexical realizada no vocativo, com anteposição do título profissional ao nome próprio, denota a atitude de distanciamento, a manutenção da interação no âmbito do relacionamento entre paciente e médico, meramente profissional. Contudo, estabelece-se um contraste entre esse vocativo e a afirmação, justificativa, que se segue imediatamente, iniciada pelo sentimento, pela necessidade de falar sobre "sentimentos", algo íntimo cuja exteriorização tem efeito potencial de desconstrução da distância entre duas pessoas.

No segundo movimento retórico, em (71), Dandara menciona sua relutância em procurar assistência médica no pré-natal:

(71) Confesso que não foi fácil tomar uma decisão e entrar em seu consultório, mesmo com indicações.

Não tenho bons sentimentos em relação à classe médica. Sei da raridade de um médico que cuida e acompanha um processo natural, como o parto, e instintivo, como cuidar da cria.

Iniciando esse excerto com um ato ilocutórico assertivo (Austin, 1975; Searle, 1999) marcado pelo item lexical "confesso", Dandara acentua um pouco mais essa aproximação iniciada com a confissão já presente, embora não nomeada, quando escreve “senti”, no excerto em (70). Desta maneira, executa mais uma das estratégias características de textos autobiográficos, cujo principal precursor é a obra Confissões, de Agostinho, escrita ainda no século IV. Essa aproximação, também por meio da confissão, é assumida como o desenrolar de uma história, cujo ponto de partida era um afastamento, a ausência de "bons sentimentos" em relação ao grupo de profissionais do qual Dr. Francisco faz parte, "a classe médica". Em seguida, faz também uma alusão a uma suposta naturalidade do parto enquanto processo, e se utiliza da metáfora animal em alusão ao maternar, verificável na seleção lexical de itens como "instintivo" e "cria", para afirmar que são raros os médicos que cuidariam e acompanhariam um processo assim. Com isso ela invoca o pressuposto de que a "classe médica" teria uma visão desnaturalizada sobre o parto e o maternar.

No próximo fragmento, em (72), Dandara desenvolve a representação da imagem que tinha dessa "classe médica": 
Quando pensava em médico obstetra pensava, primeiro, no terrorismo do parto normal que levaria nossos filhos a terem seqüelas permanentes (isso se saíssem vivos!) se não fosse a salvadora cesariana. Pensava nas inúmeras desculpas esfarrapadas que poderiam usar para me impedir de parir... Por outro lado, caso passasse na triagem e me permitissem parir, pensava na deturpação do parto: tricotomia, enema, bolsa estourada com agulha de crochê, anestesia, episiotomia, litotomia, kresteller [sic], estribos e, finalmente, fórceps. Fora os incômodos toques do pré-natal.

Além de seus sentimentos, Dandara expressa em (72) seus pensamentos, o verbo "pensava" é utilizado três vezes e o teor desses pensamentos compõe um campo semântico cuja avaliação, retomando os conceitos de Martin \& White (2005), pode ser classificada como um julgamento com atribuição de baixa estima social. Considero pouco questionável a carga negativa impressa em lexias como "terrorismo", "sequelas permanentes”, “desculpas esfarrapadas”, “deturpação do parto" ou "incômodos toques". Há também nesse fragmento a interpelação a outras mulheres, por meio do uso do pronome possessivo "nossos" que pressupõe uma afirmativa referente também às/aos filhas/os de potenciais leitoras/es da carta em pauta. Com esse uso, Dandara sinaliza a coletividade submetida ao sistema representado na "confissão" de seus sentimentos e pensamentos, todas as mães dos "nossos filhos".

Embora se trate de uma carta endereçada ao obstetra que assistiu seu parto, como já foi dito, essa carta constitui a materialização de um potencial genérico híbrido, tanto pelo fato de flutuar entre o gênero carta pessoal e correspondência comercial, como já foi dito acerca da carta de Elena, como também por se situar entre o gênero carta pessoal enviada a um destinatário direta e pessoalmente e o gênero carta aberta endereçada a personalidade pública - sabendo-se que, na maioria das vezes, o real destinatário da carta não é o mencionado na saudação, mas sim uma audiência mais ampla que, além de ser informada dessa carta, é também interlocutora e receptora da mensagem nela veiculada. Reconhecer esse hibridismo genérico é o que me faz interpretar o uso de "nossos filhos" como marca de que esta carta considera outras mulheres como potenciais leitoras e usa a interpelação como estratégia discursiva para apontar o fato de que um sistema assim diz respeito também a elas e a suas/seus filhas/os.

Em meio a sua representação, Dandara se inclui duas vezes por meio da pronominalização “me", um pronome em função de complemento dos verbos "impedir" e "permitir". Desta maneira se, realiza uma autoidentificação cuja condição é a de paciente, subjugada à agência de outrem, de algum/a representante da classe médica, no que diz respeito à possibilidade de parir ou não. Note-se que o impedimento, conforme essa representação, não teria uma justificativa legítima, mas sim fundamentada em "desculpas esfarrapadas”, expressão que 
constitui uma avaliação negativa, um julgamento indicando a sanção social pela falta de propriedade e veracidade na atitude profissional descrita. A possibilidade de parir, por sua vez, dependeria de uma "triagem", vocábulo que pode ser lido tanto como sinônimo de seleção, em termos de senso comum, quanto como "classificação de indivíduos que foram levados a um hospital ou a um Centro de Saúde, segundo as suas patologias ou segundo a gravidade da sua situação clínica”, conforme descrito no Dicionário de Termos Médicos da Porto Editora (20132016). A escolha dessa lexia condensa um enunciado discursivo correspondente à "visão pessimista do corpo feminino", considerado falho ou patológico até que, ou, muitas vezes, ainda que se prove o contrário. Ainda nesse excerto, Dandara termina de pintar a imagem que fazia da assistência obstétrica vigente, e de suas consequências para a mulher que tenha sido selecionada nessa "triagem". Com uma listagem bastante técnica de procedimentos e instrumentos realizados/utilizados rotineiramente durante o parto nos hospitais, Dandara, de certa forma, identifica a figura da mulher selecionada pela triagem como aquela que "ganha, mas não leva". O uso desses termos técnicos também constrói uma autoidentificação de Dandara como conhecedora, como membro de um grupo, de certa forma, especialista.

Feito isso, a autora informa seu sentimento com relação a essa visão que tem, ainda, do que seria um "médico obstetra padrão", no fragmento em (73):

(73) Infelizmente, a minha visão do médico obstetra padrão é essa... e não acho que esteja errada. Se eu fosse religiosa diria que uma mulher que delega ao médico toda a responsabilidade e protagonismo do seu parto estaria acreditando mais no médico que em Deus. E o mesmo diria ao médico que admite que isto aconteça, ele pensa ser melhor que Deus.

O problema maior é que no consultório os médicos falam dos benefícios da cesárea e dos malefícios ou perigos do parto normal. Mas raramente o contrário... os benefícios do parto normal e os malefícios e riscos reais da cesariana. Isso acaba pesando pro lado da cesariana...

O "infelizmente" com que inicia o fragmento em (73) é mais uma avaliação explícita na carta de Dandara, uma expressão do afeto, o registro de um sentimento negativo diante dessa imagem, dessa "visão do médico obstetra padrão", que apesar da gratidão que, declaradamente, a leva escrever essa carta de agradecimento a um integrante da "classe médica", ainda "é essa", negativa. Com a denominação "classe médica" no fragmento em (71), como estratégia de distinção, de valorização, de prestígio, mais a alteridentificação concluída em (73), quando Dandara se refere à fé cega da mulher "que delega ao médico toda a responsabilidade e protagonismo do seu parto" e que "estaria acreditando mais no médico que em Deus", assim como quando caracteriza o que "pensa ser melhor que Deus", a autora texturiza um enunciado 
relativo à proporção da assimetria, atribuída e incorporada, entre o lugar subjetivo da mulher, sua posição discursiva, e o lugar subjetivo, a posição discursiva do alto da qual atua o que ela chama "médico obstetra padrão". Ao afirmar “... e não acho que esteja errada”, Dandara parece se antecipar a uma possível reação, reagindo por meio de uma negativa da possibilidade de modalizar a visão que tem do "médico obstetra padrão", e com isso parece dar a entender que nisso está em conformidade o que pensava à época e continua pensando, mesmo após o evento conversor, o evento do parto atendido como entendemos adequado, como respeito ao protagonismo feminino.

Note-se, contudo, que na representação apresentada por Dandara, ela modaliza a convicção desse médico, que não "sabe" ou "diz" que é Deus, ele "pensa" que é Deus. Com essa alteridentificação abre-se uma brecha para ser ocupada com a pergunta sobre por que o médico “pensaria” ser Deus, que elementos sócio-históricos e culturais contribuíram ou contribuem para isso? Pois se pensarmos, mais uma vez, em termos avaliativos, agir conforme aquilo em que se acredita costuma ser algo digno de estima social. Agiria diferente o "médico obstetra padrão" caso conseguisse pensar diferente? Que estruturas discursivas precisariam ser abaladas ou demolidas para que essa mudança fosse possível? São perguntas que se me apresentam para seguir refletindo e buscando pistas sobre como minimizar o problema da violência obstétrica. Em seu texto, Dandara fala do que seria o "problema maior" fazendo um trocadilho com inversão de lugares quase simétrica entre benefícios da cesárea e do parto normal, e "malefícios ou perigos do parto normal" frente a "malefícios e riscos reais da cesariana". Entretanto enquanto seleciona "malefícios" e "perigos" do parto normal como se fossem sinônimos intercambiáveis e alternativos, Dandara não alterna, adiciona e qualifica: "malefícios" mais "riscos reais". Agindo assim ela levanta o pressuposto de que os perigos do parto normal falados nos consultórios não seriam reais, ou tão reais, quanto os "malefícios e riscos" da cesariana. Contudo aventa que, devido à prática médica, “isso acaba pesando pro lado da cesariana...”. Nessa expressão, percebemos mais uma vez a produtividade metafórica proposta por Lakoff \& Johnson (2002), na texturização de uma metáfora do cotidiano, por meio da qual se concebe a tomada de decisão como decorrente do que acontece ao pesarmos argumentos, como se estivéssemos utilizando uma balança para medida de pesos.

Continuando sua carta, em (74), a autora estende a representação de sua imagem negativa a outro grupo da "classe médica", ao grupo dos pediatras: 
levados imediatamente para longe da mãe, como se fossem propriedade do hospital, tomando os desnecessários leite nã e soro glicosado antes mesmo de mamarem o alentador leite materno no aconchego da pele da mãe. Dificultam, dessa forma, a pega do peito e depois ainda se justificam, absurdamente, quando o bebê não mama direito, que a mãe não é capaz de amamentar, que o leite é fraco, que o leite não é suficiente, dissuadindo mães de fazerem o que é melhor para os filhos. E me revolta saber que com o apoio de um bom profissional até mães adotivas amamentam.

Para análise do fragmento em (74), relembro Ligia Chiappini Leite, em sua obra o Foco Narrativo (2002), na qual menciona a diferença proposta por Percy Lubbock entre cena e sumário como estratégias narrativas:

Na CENA, os acontecimentos são mostrados ao leitor, diretamente, sem a mediação de um NARRADOR que, ao contrário, no SUMÁRIO, os conta e os resume; condensa-os, passando por cima dos detalhes e, às vezes, sumariando em poucas páginas um longo tempo da HISTÓRIA. (Leite, 2002, p. 14)

A CENA restringe a ação, apresentando-a num tempo presente e próxima do leitor, enquanto o SUMÁRIO a amplifica, no tempo e no espaço, distanciando o leitor do narrado." (Leite, 2002, p. 15)

Dessa definição, nos interessa especificamente a parte relativa à cena, por ser a opção pela qual são mostrados os acontecimentos sem mediação de um/a narrador/a, diminuindo a distância entre o fato narrado e as/os potenciais leitoras/es. Ao mencionar seus "sentimentos" em relação aos pediatras, Dandara parece dar um salto de sumário para cena, da qual se retira e delega à/ao leitor/a a tarefa de ver por ela/ele mesma/o. Sua avaliação, contudo, segue inscrita, condensada nos termos dessa cena, por exemplo, ao escrever que os bebês seriam tratados "como se fossem propriedade do hospital", representando uma forma de desumanização desses seres tratados como objetos, objetificados e alienados da mulher que acaba de os parir, que, pela sua qualidade biológica de mamífera, seria a candidata mais "natural" a acolher e nutrir esses seres recémnascidos imediatamente após o parto. Ressalte-se que, como alguém já disse em relação à amamentação, ser natural não significa ser fácil, e o contexto do nascimento pode desempenhar um papel fundamental no sentido de colaborar ou de prejudicar nesse processo. Como ressaltam Salgado, Niy \& Diniz (2013, p. 2),

o contato precoce mãe-recém-nascido também determina desfechos relevantes para os processos fisiológicos que serão estabelecidos a seguir: a dequitação da placenta, a diminuição do sangramento (loquiação), a estimulação da produção de leite e o estabelecimento da amamentação. 
A descrição de Dandara segue compondo a cena com avaliações embutidas, negativas em relação ao suplemento alimentar "desnecessário", e positiva na representação do leite materno, “alentador", e na identificação metonímica da figura materna pelo "aconchego da pele". Composta a cena, Dandara volta a um estilo narrativo mais próximo a um sumário, mediando e resumindo, ao mesmo tempo em que amplifica sua presença na avaliação dos pediatras, denormalizando com o advérbio "absurdamente", que diante da cena exposta as decorrentes dificuldades com a amamentação sejam atribuídas à incapacidade das mães, avaliação que culmina em "revolta", numa apreciação negativa da pressuposta incompetência desses pediatras - o oposto do que seria um "bom profissional" capaz promover até mesmo a amamentação em casos de adoção.

Concluída essa primeira parte de sua carta, em que Dandara fala dos sentimentos e présuposições com relação à atenção obstétrica vigente, ela passa, no excerto em (75), ao porquê de, apesar disso, ter, enfim, buscado um médico, ainda que incrédula.
Diante disso, confesso que durante a minha gravidez não tinha a intenção de pisar em um consultório médico. Eu deixaria acontecer...
Maaas... Pra não contrariar familiares e para cumprir o protocolo fui pra consulta. E, bem... já que lá estava... fui perguntando, perguntando, perguntando... no início bastante constrangida, pois estava num consultório médico sem um mínimo de confiança no que fosse dito. Mas no fim, inesperadamente, mais tranquila e convencida de que meu parto normal poderia sim acontecer em Maceió. Seria possível parir com a presença do pai do meu filho, coisa que não permitiram no meu primeiro parto, já que a sala de parto estava tão cheia de estudantes que meu marido não cabia e, bem... eu era o objeto e meu marido... bem... o hospital não tinha nenhum interesse nele. Enfim... fui pro hospital disposta a sair correndo caso me visse em vias de ir pra uma cesariana desnecessária.

Ao mencionar, precedida de um longo "maaas", a influência dos familiares e a necessidade de “cumprir o protocolo", Dandara representa a importância do contexto sócio-histórico e das crenças sociais nas decisões que as mulheres gestantes tomam, e se autoidentifica como uma mulher que agiu de acordo com uma norma subjetiva, componente da estrutura social àquela altura. Para Rodrigues, Assmar, \& Jablonski, (2002 apud Brito \& Camargo, 2011, p. 284) essas normas seriam "definidas como crenças que podem originar das pressões exercidas por seu entorno social, como familiares, amigos e a sociedade, de forma que normatiza o que é importante para cada indivíduo". No que diz respeito à mulher gestante é imperativo considerar a questão do gênero presente nessas crenças. E considerando-se que essas normas, crenças e o 
gênero são componentes estruturantes do discurso, lembramos com Michelle Lazar (2007, p. 147) que

[a] ideologia de gênero é hegemônica na medida em que, muitas vezes, não aparece de maneira alguma como dominação, aparecendo sim como amplamente consensual e aceitável para a maioria em uma comunidade. [...]. A assunção de que tudo é assim mesmo e a normalidade de tal conhecimento é o que mistifica ou obscurece o diferencial de poder e da desigualdade envolvida.

$[\ldots]$

Reivindicar que a ideologia de gênero patriarcal é estrutural é dizer que ela é legitimada e renovada em instituições e práticas sociais de uma sociedade, que medeiam entre o indivíduo e a ordem social.

A naturalização da hospitalização do parto, com perda de autonomia para mulher, assim como a visão de que o corpo da mulher e as decisões sobre ele dizem respeito à comunidade, e não somente a ela, e o reconhecimento da "classe médica" como inquestionável autoridade, quase divina, nas decisões quanto a ações a serem executadas em questões relativas à gestação e ao parto podem ser apontadas como uma das colunas que sustentam a prática obstétrica como se encontra. Por outro lado, reconhecer a importância das crenças e instituições sociais, como a família, nesse contexto aponta para uma possibilidade de mudança discursiva, se reconhecermos que campanhas de denormalização, de escandalizacão da violência obstétrica devam buscar alcançar não somente as mulheres, mas todas/os a sua volta. O "protocolo" a ser cumprido é também discursivo e, apesar de aparentemente estável, também é mutável: como tudo que é sólido pode desmanchar no ar. Seguindo com Lazar (2007, p. 147), concordo que

[e]mbora um foco na transgressão e na criatividade seja importante, isso tem de ser cuidadosamente considerado em relação aos constrangimentos e possibilidades oferecidas por particulares estruturas e práticas sociais. Caso contrário, uma celebração da agência por conta própria pode ser romantizada.

Quer dizer, embora a ação individual, a resistência da mulher, seja crucial para a mudança discursiva, isso não é tudo, o (de)mérito de qualquer processo relacionado ao ritual do parto tem sempre um aspecto comunitário que não pode ser desconsiderado.

Outro "mas" aparece no fragmento em (75), outro elemento de coesão texturizando uma extensão, uma alternativa à falta de confiança que imperava até esse momento de virada, reforçada pelo advérbio "inesperadamente" que aparece na sequência. O texto continua demonstrando que os "sentimentos" de Dandara em relação à assistência obstétrica não se fundavam meramente em pré-suposições, antes resultavam de sua experiência anterior, o seu 
primeiro parto, narrado em um sumário, condensado e resumido em quatro linhas, nas quais, entretanto, cabe sua autoidentificação como "objeto" numa sala "cheia de estudantes". Concluido esse fragmento, a identificação de Dandara ainda não corresponde à de uma mulher confiante no sistema, caso contrário não se diria "disposta a sair correndo [do hospital] caso [s]e visse em vias de ir pra uma cesariana desnecessária”.

O fragmento seguinte, em (76), é dedicado ao "agradecimento" ao médico Francisco, dentre outras estratégias, por meio do ato ilocutório viabilizado pelo uso do verbo performativo “agradecer”, repetido várias vezes neste e no fragmento seguinte.

Só tenho realmente a agradecer Dr. Francisco, pois não precisei sair correndo. $\mathrm{Na}$ verdade escrevo para tentar expressar o meu mais profundo agradecimento pelo maravilhoso parto normal do meu segundo filho, Rudá, embora,

- meu filhote estivesse com uma circular de cordão;

- meu bebê não estivesse encaixado

- embora pudesse inventar ainda mais alguma desculpa pra me levar pra mesa de cirurgia.

Gostaria de agradecer por ter acompanhado o meu pré-natal com tanto respeito, sem os infinitos toques do SUS e acompanhado o meu parto sem enema, tricotomia, kristeller, estribos, fórceps, episiotomia e anestesia, por permitir que inclinasse a cama, por permitir o acesso ao meu marido, respeitando o momento do rompimento da bolsa e permitindo que meu filhote se encaixasse na hora dele.

Dandara inicia esse excerto com o verbo modal "ter (...) a", evocando a modalidade deôntica, obrigação ou necessidade, precedido e seguido de advérbios, o primeiro, "só", advérbio de exclusão, e o segundo, "realmente", que além modalizar epistemicamente, evocando o comprometimento com a verdade dessa afirmação, também funciona como elemento de reforço, nos termos de Pardo (2011), ou intensificador, nos termos de Martin \& White (2005). Toda essa ênfase, modalizada categoricamente, tanto quanto à obrigação ou necessidade, assim como quanto à verdade do narrado, tem como efeito a situação da assistência obstétrica num outro patamar possível, embora aparentemente excepcional, e representado como realizado e empírico. Note-se que na parte inicial da carta, a alteridentificação afeta aos médicos se configura num plano geral, mas, daqui para frente, Dandara se põe a reportar uma experiência concreta, parecendo dizer que, se o inferno é aqui, o paraíso também pode ser, como alguém que foi ao inferno e voltou, conheceu os jardins do Éden e nos contou.

Na continuação desse segmento, em (76), Dandara aponta dois aspectos que são cotidianamente utilizados pela "classe médica" para supostamente justificar a necessidade de uma cesárea, a “circular de cordão" e o bebê desencaixado, além de textualmente compor um espaço variável, 
que poderia ser completado com qualquer uma das chamadas "indicações fictícias para cesárea". Seguindo, Dandara indica que seu resultado se dede à postura do médico desde a época do pré-natal. Interessante perceber o item lexical selecionado para caracterizar sua atuação, "acompanhar" tanto o pré-natal, quanto o parto, diferente do muito utilizado "fazer", seja o pré-natal ou o parto. Nessas nuanças são constituídas posições subjetivas distintas, pois atribuem, na primeira forma, o protagonismo à mulher, na segunda, ao médico.

Essa situação discursiva, marcada pela seleção lexical, oscila, contudo, com relação a esse protagonismo, ou mesmo com relação ao grau de autoridade de cada pessoa nesse processo relacional entre médico e mulher. Afirmo isso, pois, seguindo adiante, Dandara seleciona repetidas vezes o verbo "permitir", ao relatar o fato de Dr. Francisco não ter agido no sentido de impedi-la de gozar de seus direitos, como são parir acompanhada, ter o tempo fisiológico do processo respeitado, decidir sobre que posição tomar durante o trabalho de parto. Essa seleção lexical configura um processo de potencial identificação do obstetra como dono do poder, e tem como efeito uma vinculação com a representação da primeira parte da carta.

No excerto em (77), Dandara segue agradecendo e, narrativamente, parece repetir o salto entre a imagem inicial do "médico obstetra padrão", identificado como o protagonista, único responsável por permitir ou não qualquer conduta durante o parto, e um outro médico possível, o Dr. Francisco, diante do qual agora se "permite", ela mesma, viver seu processo "sem tensão".

(77) O tratamento e a forma como fui recebida e conduzida me tranquilizaram de tal forma que pude me permitir simplesmente esperar, sem tensão. Agradeço por ter respeitado a minha fisiologia e a minha dor e por me dar segurança de que acompanharia meu parto sem intervenções. Agradeço as palavras mansas me pedindo pra respirar com calma e do jeito certo, que isso faria bem ao meu bebê. Agradeço por me acalmar ao dizer pra enfermeira que com a dor que eu estava sentindo era normal que a pressão estivesse alta. Agradeço por me oferecer a banheira de hidromassagem, isso me deixou segura de que tinha liberdade para escolher e decidir o que era melhor pra mim naquele momento. Agradeço a delicadeza com que conduziu o parto e acalmou meu marido. Agradeço a massagem e a bolsa de água quente que foi o que realmente aliviou as minhas dores, tornando o trabalho de parto praticamente indolor. $\mathrm{E}$ agradeço por ter acompanhado o parto com segurança, com acompanhamento de batimentos cardíacos.

Agradeço muito por ter sido delicado comigo no meu momento de fragilidade, por garantir meu parto normal respeitoso do início ao fim. Por ser um médico digno de ser chamado de médico humanizado.

Agradeço, principalmente, por permitir que meu filho mamasse antes mesmo de cortar o cordão umbilical, o que contribuiu, certamente, para que ele mamasse tão direitinho, sem tanta complicação como foi com meu primeiro filho, que só queria dormir, após ser afastado de mim e de provavelmente tomar nã [sic] e soro glicosado. 
De “permitir" em (76), Dandara muda para “respeitar", em (77), procedendo um deslocamento na identificação do médico. Dr. Francisco, além do respeitar, é identificado por meio da seleção de expressões como "palavras mansas", "acalmar", "oferecer", "liberdade para escolher e decidir", “delicadeza", "massagem e bolsa de água quente", "segurança”, “delicado", “respeitoso", "digno", que culminam com o qualificador "humanizado". O verbo permitir volta a aparecer, na menção ao momento da amamentação imediata do recém-nascido Rudá, associada à recordação da experiência com as dificuldades para amamentar o primeiro filho, quando não lhe foi "permitido" fazê-lo logo após o nascimento. Esse fato me faz acreditar que o verbo permitir se encontra numa rede de associação com as memórias de sua experiência anterior, quando a representação ativa talvez ainda não se inserisse num campo mais emancipatório como esse em que se encontra Dandara no momento de redação da carta, cujas linhas trazem indícios da identificação em disputa sobre como seria, ou deveria ser, o "médico obstetra padrão".

No excerto seguinte, em (78), a mãe de Rudá segue essa reflexão sobre o que é, ou deve ser, um/a médica/o obstetra, supondo um diálogo potencial, com uma resposta imaginada, proferida por Dr. Francisco:

Você diria "não fiz mais que a minha obrigação"... mas eu digo que não fez menos e com um grande diferencial, com respeito à fisiologia, ética profissional e, principalmente, com humanização.

Não sei como teria sido se meu trabalho de parto fosse mais longo, mas acredito que seria tão bem conduzido como foi com o meu rápido trabalho de parto.

Após a possibilidade de o médico afirmar não ter feito mais que sua obrigação, Dandara segue com uma extensão, composta por uma alternativa, marcada por "mas", e uma adição, "marcada" por "e". Essa passagem corrobora a sugestão de que o processo identificatório segue em disputa, diante de uma realidade em que a regra seria não cumprir com a obrigação, o que, de certa forma, aparece nas palavras de Dandara como "diferencial", inclusive princípios norteadores de qualquer atuação profissional, ou relacionamento humano, como considero serem a ética e o respeito, e também, como ela escreve enfaticamente, a "humanização".

No fragmento final da carta, em (79), reaparece a questão do protagonismo, também de forma dúbia como acontece com a identificação da figura médica.

(79) Em tão poucas consultas confesso que sinto um respeito enorme pelo profissional que é. 
Estará sempre em minhas lembranças com muito carinho. Será sempre o personagem principal na história do maravilhoso nascimento do Rudá que sempre contarei "Dr. Francisco Silva e Souza, ético, profissional, humano, que me permitiu ser protagonista do meu parto e parir meu filho".

Muito obrigada,

Dandara Paraguaçu.

Dandara afirma em (79) que Dr. Francisco "sempre será o personagem principal na história" do seu parto, embora a seguir afirme ter sido ela a "protagonista", aquela que pariu o filho. Entretanto, seu próprio protagonismo é representado como tendo acontecido apenas porque um médico, agora citado com nome e todos os sobrenomes, numa clara estratégica narrativa de valorização, foi suficientemente "ético, profissional, humano" para lhe "permitir" tal feito. Vejo nessa passagem um exemplo claro de como as estruturas discursivas constrangem as ações individuais, mesmo no caso de mulheres que já deram grandes passos emancipatórios, como não se pode deixar de afirmar com relação a Dandara.

Brah (2006, p. 351), num artigo em que discute diferença, diversidade e diferenciação, relembra que "relações patriarcais são uma forma específica de relação de gênero em que as mulheres estão numa posição subordinada", por exemplo, à tutela de um médico, cuja permissão para viver seu protagonismo é condição sine qua non, além de configurar tamanha condescendência que o torna digno de ser lembrado como o "principal personagem" de um parto assistido com dignidade e respeito. Nesse sentido, eu qualificaria o desfecho da carta de Dandara com efeitos discursivos potenciais de reificação do discurso cujas estruturas patriarcais fazem parte da engrenagem que mantém e legitima a violência obstétrica.

Entretanto, como gramsciana que quero ser, recordo que meu objeto de análise, a carta de Dandara, foi escrita, ou pelo menos publicada, com fins pragmáticos, quais sejam, alcançar uma audiência muito mais ampla, que de forma alguma se limita ao médico que já cumpre suas obrigações. Agostinho também faz uma confissão a Deus, apesar de reconhecê-lo como onisciente, e antevê e se antecipa a um questionamento possível, inserindo em seu livro um capítulo intitulado "Confessar a Deus o que ele já conhece?", ao que se segue a resposta: "Por que razão vos narro, pois, tantos acontecimentos? Não é, certamente, para que os conheçais em mim, mas para excitar o meu afeto para convosco e o daqueles que leem estas páginas" (Agostinho, 1980 [397 e 398], p. 209).

Com isso em mente, reconheço esse desfecho, no qual Dr. Francisco é colocado num pedestal, como uma forma estratégica de ocupação de trincheiras, evitando o embate frontal, ou um 
voluntarismo mal calculado e pouco produtivo. Buscando dar passos curtos, mas certeiros, rumo à assistência que almejamos, Dandara conversa em sua carta também, e quem sabe, especialmente, não com Dr. Francisco, mas com o "médico obstetra padrão", aquele que "pensa ser melhor que Deus". Assim sendo, parece-me bastante efetivo, em termos de desconstrução e reconstrução discursiva, ainda que gradual, oferecer a esse personagem uma outra forma possível de exercer o protagonismo na assistência obstétrica, na posição e nas tarefas que lhe competem ao obstare (estar ao lado) sem obstar (causar estorvo ou empecer).

\subsection{Algumas considerações.}

Passo agora a uma tentativa de retomar os enunciados presentes nessas duas cartas. Iniciando com a carta de Elena e finalizando com a carta de Dandara. Ao modo como procurei fazer também para os relatos de Tânia e de Lívia.

Pois bem, por meio da análise da Carta de Elena, pode-se desvendar a composição retórica do texto, cujo início é sutil, enquadrado nas expectativas formais relacionadas ao gênero carta e reflete a assimetria entre médica e (ex-)paciente. Ademais, percebe-se como desde o início da mensagem, num movimento circular e crescente, há uma alternância entre assunção de culpa e responsabilização da obstetra pela cesárea sofrida e por seus desdobramentos. Entretanto, a culpa aparentemente assumida é também, ao longo de todo o texto, atenuada pelo estilo irônico da narrativa, que ao fim e ao cabo leva Elena a se despedir definitivamente dessa culpa e a julgar explicitamente a postura da médica.

A avaliação do comportamento da médica constitui-se no enunciado da crítica mais ampla ao modelo de assistência vigente no Brasil, o que materializa no texto aspectos da luta hegemônica que se trava também no discurso - no movimento pendular entre a filiação ao discurso da intervenção - quando Elena não questiona os critérios do intervencionismo cirúrgico, mas apenas sua própria condição física em relação a esses critérios - "tudo estava perfeito", então "não dei muita importância" - e a evocação do discurso da mobilização pró parto natural, especialmente ao final da missiva.

A tonalidade espraiada pela carta afora é de intensificação e negação: a intensidade da experiência e da necessidade de verbalizar os afetos, julgamentos e apreciações que dela resultam; a negação à postura da médica e às próprias atitudes nas circunstâncias representadas. Em relação aos estilos materializados na carta, é marcante a identificação evocada da médica 
com o estilo da 'cesarista fofa', responsável pela conversão sutil do físiológico em patológico, com culpabilização da mulher e de seu corpo pelo insucesso no intento do parto, sem nunca admitir explicitamente sua preferência pela cirurgia. A carta de Elena é rica em emoção, e, por isso, deixa ver algumas das consequências psicoafetivas que ultrapassam o talho na carne, deixando também um talho na alma.

No que refere ao texto de Dandara, a necessidade de falar sobre sentimentos aparece como justificativa da missiva, trazendo também ela os afetos ao primeiro plano na busca por uma assistência obstétrica "humanizada". Assistência essa que infelizmente não corresponde à assistência "padrão". Na qual não só afetos e sentimentos têm sido desconsiderados, mas também o aspecto "natural" e "instintivo" do parto.

Um enunciado marcante seria o fato de que parir naturalmente é considerado, no contexto da atenção obstétrica brasileira atual, uma missão quase impossível, dado que primeiro a mulher precisa superar a "triagem" realizada por um pré-natal, recorrentemente, realizado com a busca constante de obstáculos para a aprovação da mulher como candidata ao parto vaginal. Entretanto, mesmo superando essa fase, o parto muito provavelmente não será um parto natural, pois as intervenções de rotina transformam, como já foi dito, o ritual do parto num "circo de horrores" (Lanski apud Batalha, 2012, p. 9), no qual não se pode falar de parto natural ou humanizado, ainda que vaginal, mas de um parto Frank. Parte desse circo de horrores seria a objetificação de mulheres e bebês, tratados como se fossem “propriedade do hospital”.

Outro enunciado deduzível analiticamente da carta de Dandara diz respeito ao papel fundamental da comunidade, da sociedade como um todo, na busca por uma assistência obstétrica digna. Se buscamos fazer valer os direitos sexuais e reprodutivos das mulheres, precisamos dialogar, alcançar também aquelas pessoas que convivem com as mulheres, atuando numa reconstrução discursiva sobre qual seria o "protocolo" adequado para uma mulher gestante ou parturiente. $O$ processo de identificação da classe médica também precisa tomar novos rumos, assegurando a essas/es profissionais o protagonismo nas funções que realmente lhes cabem. Conseguindo atuar atendendo às expectativas de humanização, como profissionais que atuam com "delicadeza", que sabem pronunciar "palavras mansas", que sabem "acalmar", que reconhecem o direito à "liberdade para escolher e decidir", representando "segurança", ética, respeito e dignidade. 



\section{CAPÍTULO 6 Análise sinóptica.}

A chegada de uma criança ao mundo é sempre como um milagre. Nós imaginamos a mulher como a deusa desse nascimento. Ela acaba de conseguir o mais extraordinário, grandioso, melhor, mais louco e inacreditável que uma pessoa pode conseguir. Eis que passa a existir um ser humano que até então não existia.

(Christina Mundlos)

O objetivo neste capítulo é apresentar uma sinopse das análises estrutural e fina, retomando os tópicos principais e evidenciando os enunciados ${ }^{34}$ delas resultantes, organizando-os de modo a oferecer uma explanação da representação discursiva presente nos textos analisados, no que diz respeito ao feixe discursivo em questão, que se refere à gestação, ao parto e à assistência obstétrica no contexto brasileiro deste início de século. Opto, então, neste momento, por fazer essa análise sinóptica ao mesmo tempo em que procuro responder as questões que guiaram este estudo. Vamos a eles.

6.1. Como se identificam as mulheres com respeito ao período pré-natal, ao momento do nascimento e ao pós-parto?

Com relação ao período do pré-natal, até antes do parto, e mesmo durante o parto, é recorrente a autoidentificação por meio da referência à ingenuidade ou à inocência, sendo a experiência do parto ou da cesárea o ponto de inflexão, correspondente a uma conversão, em termos agostinianos (Agostinho, 1980 [397 e 398], p. 209) e autobiográficos (Lejeune, 1975; Hammerschmidt, 2011), um divisor de águas que geralmente permite o distanciamento entre a narradora e a identidade atribuída à protagonista do texto situada no início da trajetória contada. Como vimos exemplarmente no relato de Aída, na seção 3.1, no fragmento em (1), repetido a seguir:

(1) Eu, do alto da minha inocência, e crendo que você jamais diria algo para me enganar apenas para facilitar seu feriado de Corpus Christi, aquiesci. Eu não queria, de fato, provocar dano à minha filha. Uma hora depois você se despedia de mim e ia atender o dia cheio do consultório.

\footnotetext{
${ }^{34}$ Enunciado na acepção de Margarete Jäger (1996; prelo) e Sigfried Jäger (2012), ou seja, “um denominador comum de conteúdo, que pode ser abstraído de orações e de textos”, um átomo do discurso.
} 
Esse ponto de inflexão é geralmente seguido de um período de dor (física e emocional), abalo da confiança em si mesma e no próprio corpo, uma espécie de luto, na maioria das vezes já superado no momento da escrita, ou em superação também por meio dela. Nessa escrita, outra recorrência observada é a identificação da narradora de cada texto, como uma mulher que deu a volta por cima, que se percebe como participante ativa em um projeto coletivo de resistência e emancipação feminina contra a violência obstétrica. Falando dessa posição discursiva, essa mulher convida, mais ou menos explicitamente, suas/seus leitoras/es potenciais a se unirem nessa causa, sejam elas mulheres ou profissionais da assistência. Esse convite e a expectativa da solidariedade para com a causa não surpreendem quando consideramos as características próprias do gênero discursivo em foco, surgido como umas das estratégias de resistência dentro do movimento. Como Nara, no excerto copiado de (27), da seção 3.10:

Dr. Felipe, nesse momento da carta o senhor deve estar se perguntando o que quer essa maluca? Em primeiro lugar eu quero te perdoar. E depois essa carta tem também efeitos terapêuticos, pois depois de três anos consigo escrevê-la sem nenhuma lágrima nos olhos. Em terceiro lugar eu tenho me realizado usando minha própria experiência para alertar outras mulheres. Vamos ver se eu consigo atingir meus objetivos com ela. Algumas coisas precisam então ser ditas.

Ademais, as autoras de vários textos denotam terem sido, em momentos diversos, percebidas, ou se sentido, como apenas um número a mais, entre tantos outros pelos quais eram identificadas e mesmo chamadas pelas/os profissionais da assistência, especialmente durante o pré-natal. Essa percepção está diretamente interligada com o desfecho, avaliado negativamente, da forma como foram (des)assistidas no momento do nascimento de suas/seus filhas/os, não raro por meio de uma cesárea indesejada e muito provavelmente desnecessária. Nesse sentido, Iêda relatou em (4), excerto da seção 3.1 que volto a apresentar:

Durante o pré-natal, fui atendida por plantonistas sem nome. Também não me lembro do rosto de nenhum deles. O meu nome variava conforme o número escrito no papel de senha da fila de espera: um dia eu era 234, outro 525.

Outra identificação encontrada é a figura da mulher que, apesar de medos e dores, consegue se insurgir, minimizando ou ressignificando essas dores e medos de forma a não permitir que esses sentimentos ou sensações a impedissem de lutar pelo parto desejado. Luta que as leva, entre outras coisas, a romper com expectativas sociais ou familiares, buscando caminhos alternativos 
de assistência numa fuga consciente diante do modelo predominante de assistência obstétrica hospitalizada, marcada pela violência institucional. Esse feito é, por vezes, narrado de maneira idealizadora convertendo a autora do relato num verdadeiro modelo a ser seguido, no que poderíamos chamar de mais uma heroína sem estátua ${ }^{35}$, heroína da resistência. Essa heroína seria alguém que teve a ousadia, ou a coragem, de rever e questionar suas certezas e checar seus fundamentos, conseguindo por meio disso escapar à sina que acomete cotidianamente tantas mulheres. Lívia, por exemplo, se autoidentifica assim, como no fragmento em (56) repetido a seguir:

(56) Olho para trás e respiro aliviada todos os dias quando penso que sempre é tempo de mudar. Que basta ter coragem para conhecer o novo e mudar o ponto de vista. Que ter desconfiado de tantas certezas me fez renascer como mulher. Ter parido da forma que eu queria fez de mim uma mulher realizada!

A visão pessimista do corpo feminino, um dos pilares de sustentação da assistência obstétrica medicalizante e intervencionista também foi inculcada muitas vezes no processo autoidentificacional das mulheres, que em algum momento do pré-natal, parto ou pós-parto se representam convencidas da suposta insuficiência ou incapacidade de seus corpos para parir. Esse aspecto da identificação tem contribuído frequentemente para que nos submetamos sem questionamentos a procedimentos violentos. Contudo, na maioria dos textos aqui analisados, essa forma de se identificar diz respeito à mulher narrada, situada no passado, antes da superação, após a qual as autoras normalmente se identificam como mulheres que acreditam em suas potencialidades corporais e responsabilizam terceiros pelo abafamento, o impedimento da realização desse potencial. Elena se manifesta assim a esse respeito, em sua carta, cujo excerto (67) retomo agora:

(67) Hoje sei os motivos que levam um médico a inventar qualquer desculpa para fazer uma cesárea e isso é ainda pior de se saber. Não é ético. Até hoje não sei os reais motivos da complicação que tive após o parto. Foi outra falha sua, não foi honesta para me contar o que aconteceu. Simplesmente disse que "acontece". E eu sei que não acontece! Será que foi a gaze que você esqueceu dentro de mim? Será que você arrancou a placenta, que, depois das 40 semanas é tão "fraca" em nutrir o bebê que até gera uma hemorragia, de tão ligada que ainda estava à minha circulação?

\footnotetext{
${ }^{35}$ Faço essa alusão em homenagem ao belo trabalho realizado em uma escola pública de Brasília sob orientação de minha colega María del Pilar Acosta para reconhecer e valorizar a luta de mulheres "guerreiras que lutaram, correram perigo para que a sociedade mudasse, que deram duro e seu melhor". Ver mais em http://heroinassemestatua.blogspot.com.br/?view=snapshot.
} 
Em conexão com a expressão e concretização potencial do próprio corpo, e em contraposição a essa visão pessimista da fisiologia feminina, as autoras também se identificaram fortemente com seus corpos, ou melhor, como mulheres que souberam ouvir seus corpos. Corpos que, de certa maneira, se personificavam, posicionando-se no primeiro plano, sobretudo no momento imediatamente anterior e durante o parto; corpos que se impunham como formas de saber-poder parir, formas de saber-poder tantas vezes silenciadas e ignoradas nas ações da medicina androcêntrica, tecnicista, intervencionista e misógina. Esse corpo pelo qual as autoras se identificam se impõe como saber instintivo, associado à metáfora animal, à mulher fera, que ruge e que pare naturalmente como outras mamíferas de grande porte, como é a Leoa, fêmea animal metaforicamente aludida em várias passagens. Sobre o papel do corpo durante o parto, retomo Bertha no excerto em (30), da seção 3.12, e a fala de Tânia sobre o aspecto feral do parto, em (80), da seção 4.1, ambos reproduzidos novamente a seguir:

Parir pode curar e eu ainda não sei bem exatamente quais das feridas recebeu o remédio, mas sei que o alívio foi imediato. O corpo, tendo o que pediu, se acalmou. O coração ficou leve.

$[\ldots]$

Quiseram me fazer massagem, o toque aumentava a dor. Era meu corpo me dizendo: agora o negócio é entre a gente e mais ninguém.

$[\ldots]$

Ninguém me mandou fazer força quando eu não queria, fora de hora. Pra quê? Meu corpo trabalhava sozinho, a mim cabia sentir, consentir, urrar e aguardar.

Sentia minha alma instintiva gritar a mesma voz. A Leoa tomou meu ser e a cada gota de chuva que caia no quintal mais eu entrava nos meus instintos, mais eu sentia cada célula feral tomar conta de mim, mais eu sentia a exuberante luz preenchendo minha vagina e meu ser racional e medroso morrendo.

Esses instintos se associariam à identificação das mulheres como seres que, além de sua racionalidade, também se permitem viver sua irracionalidade, animal, mística e espiritual, aquilo que algumas chamaram de Feminino Sagrado. Esse sagrado está presente na identificação explícita ou subtendida das mulheres como deusas durante o trabalho de parto, numa manifesta associação emancipatória de si mesmas, ou das mulheres que dão à luz, como detentoras de um poder supremo, de quem pode trazer à vida um ser humano a "sua imagem e semelhança". Essa identificação se dá durante o trabalho de parto em meio a um turbilhão de alternância entre racionalidade e irracionalidade, controle e descontrole, medo e segurança, dores e alívios, feminino e... masculino? 
Com relação ao masculino, há nos relatos uma desconstrução discursiva dos papéis que se costuma atribuir a homem e mulher no que diz respeito à gestação e ao parto. A representação da gestação como um processo afeto tanto a homens quanto a mulheres promove a participação ativa e efetiva do homem nesse período, assim como no momento do nascimento. Isso tem como consequência um ressignificar da responsabilidade tantas vezes (auto)atribuída somente à mulher em relação à maternidade, além de potencialmente poder minimizar a solidão experimentada por tantas mulheres diante das exigências advindas com o nascimento de uma criança. Uma reconstrução discursiva sobre os papéis dos homens nesse contexto ajudaria a evitar que, no momento dos nascimentos, mulheres se vissem abandonada em ambiente hospitalar, impedidas de ter um/a acompanhante de sua escolha, ainda que não tivessem optado por um projeto autônomo e independente de maternidade, mas, sim, desejassem e requisitassem a presença do futuro pai durante a dor e a delícia do momento do parto, assim como durante os meses de expectativa que o antecedem. Ocorrendo essa mudança, possivelmente, não leríamos mais que uma mulher tenha optado pela intervenção cirúrgica por não poder ser acompanhada durante um parto normal, como Laura escreve sobre sua decisão, em (21) da seção 3.8, reproduzido aqui:

Bom! Por eu não ter me informado antes, meu filho nasceu de cesariana. $\mathrm{O}$ meu plano só cobria um hospital para partos em toda a [cidade] e esse hospital não liberava a presença do pai nem no pré-parto e nem durante o parto. No pré-parto eu teria de ficar em uma sala junto com várias outras mulheres passando pela mesma situação. Durante o parto seríamos eu, meu filho e a tropa médica.

Independentemente da presença ou não do pai biológico nesse processo, fato é que se pode dizer ser, praticamente, unânime a necessidade de companhia durante o momento do nascimento. Uma mão para segurar parece ser a primeira necessidade de qualquer parturiente, caso consideremos o universo das autoras que colaboraram com esta pesquisa, mulheres que também se identificaram pela vontade de parir, apesar de dúvidas, medos, receios, dores, que poderiam, ou deveriam, ser acolhidos e apaziguados pelo conforto da mão de alguém.

Nos casos de superação do luto após a percepção, ou o reconhecimento da violência obstétrica sofrida, a identificação das mulheres passa por uma cíclica alternância entre autoculpabilização e responsabilização da/o agressor/a ou do sistema de assistência vigente. Em todos os casos, também naqueles em que não se denuncia violência, as mulheres também se identificam pela necessidade de verbalizar afetos, julgamentos, apreciações, pela necessidade de serem ouvidas. Como Dandara, cujas palavras, já analisadas em (70), na seção 5.2, reapresento agora: 
Prezado Dr. Francisco Silva,

Senti a necessidade de compartilhar aqui meus sentimentos em relação ao meu parto.

Por fim, pode-se dizer que a identificação das mulheres nos textos analisados também se constitui pela esperança fundamentada na ação de cada uma nesse projeto emancipatório coletivo. Como disse recentemente Adelir Lemos de Góes ${ }^{36}$ com relação ao dia em que foi submetida contra sua vontade a uma cesárea, procuramos transformar limões em limonadas, de forma que a violência sofrida individualmente não seja em vão para o coletivo de todas as mulheres em luta (ou não) pela garantia de seus direitos sexuais e reprodutivos, pelo respeito e a dignidade dos templos que são nossos corpos.

6.2. Como é representada/identificada a figura da/o profissional da assistência que a acompanha nesse período/momento?

Com relação à figura da/o profissional, podemos falar dos enunciados referentes não somente à assistência vivida, mas também sobre a expectativa relativa ao que seria a assistência obstétrica de rotina. A identificação do que seria a/o médica/o obstetra padrão corresponde a uma imagem compartilhada, baseada tanto em experiências pessoais, quanto em relatos de outras pessoas. Infelizmente, essa imagem não pode ser qualificada como positiva e a conhecendo, torna-se mais fácil entender a "busca por dignidade" traduzida na demanda por cesáreas eletivas no Brasil (Diniz, 2009, p. 321), quando mulheres procuram encontrar num ambiente espaço-temporal pré-agendado as benesses e o bom tratamento esperados na relação entre cliente e prestador/a de serviço, escapando assim às atrocidades associadas à "obstetrícia de linha de montagem" (Diniz \& Chacham, 2006, p. 83), e ao "parto Frank" (que de normal não teria nada).

$\mathrm{Na}$ representação vigente entre minhas colaboradoras de pesquisa, um/a médica/o escolhida aleatoriamente, muito provavelmente, seria identificável por uma disciplina militar, por funcionar como parte de uma engrenagem maquinal, por exercer, ainda durante o período prénatal o que chamaram "terrorismo do parto normal", por associar essa forma de parir a diversas negatividades, sem que o mesmo seja feito para o procedimento cirúrgico. A identificação da/o

\footnotetext{
${ }^{36}$ Em reportagem publicada online pela revista Crescer, disponível em http://revistacrescer.globo.com/Voceprecisa-saber/noticia/2016/10/somostodosadelir-mulher-que-foi-submetida-forca-uma-cesarea-no-rs-estuda-parase-tornar-enfermeira-obstetrica.html, acesso em 23 de outubro de 2016.
} 
cesarista fofa/o e da/o médica/o padrão se dá em oposição ao que seria um/a médica/o humanizada/o.

As/Os primeiras/os não seriam confiáveis e exerceriam já durante o pré-natal o terrorismo do parto normal, por meio de estratégias diversas de persuasão da gestante quanto às supostas vantagens da cesariana, ou ainda mais intensamente, do paulatino convencimento da mulher, da inculcação de uma suposta incapacidade sua ou de seu corpo para que possa parir, na maioria das vezes sem em momento algum assumir sua propensão para a intervenção cirúrgica em detrimento do acompanhamento do processo fisiológico. Especialmente a figura da/o cesarista fofa/o deixa entrever um padrão de atuação característico das relações médica/o-paciente permeadas pelo sistema capitalista, orientado por estratégias mercadológicas, do tipo "tempo é dinheiro", e em que o importante é tentar fazer a consumidora (no caso a paciente) acreditar que você vende exatamente o que ela precisa, para que ela, por fim, compre exatamente o que você quer vender. Nas palavras de Tânia, retomadas em (81) da seção 4.1, esse enunciado se realiza assim:
Busquei um G.O. que fizesse parto normal e acreditei. Acreditei que todos os procedimentos e instruções eram para que tudo desse certo, que me levasse ao meu parto. Mas não tinha ideia do quão enganada eu estava. Por ter essa confiança nele, sequer procurei outras pessoas, afinal, ele era "O" medico todo fofo, atencioso... eu nem desconfiava que existisse um movimento pela humanização do parto, que existia a tal "violência obstétrica", ou mesmo que ele pudesse, de fato, estar mentindo pra mim em algum momento. Gente, para e pensa: ele mentir seria algo antiético, certo?

Entretanto, não se deixou de mencionar a ideia de que essas/es médicas/os também seriam e vitimadas/os por um sistema que as/os compele a tratar seres humanos como números, desumanizando assim não somente o serviço que oferecem, mas também a si mesmas/os por se tornarem peças de engrenagem em um sistema mecanizado, de precarização do trabalho, em que estão sempre "muito ocupada[s/os]", tantas vezes como meros "plantonistas sem nome", numa vida profissional que é uma verdadeira "canseira" - como comentam Iêda, em (82), seção 3.1, Amanda, em (83), seção 3.5, e Elena, em (57), seção 5.1, excertos repetidos a seguir:

(82) Durante o pré-natal, fui atendida por plantonistas sem nome. Também não me lembro do rosto de nenhum deles. O meu nome variava conforme o número escrito no papel de senha da fila de espera: um dia eu era 234, outro 525.

(83) Se você procura um médico convencional, ele provavelmente vai ser do tipo que gosta de cesárea. Mas é claro! - Cesárea é muito mais simples, rápida, tranquila, e lucrativa. Primigestas costumam ficar doze horas em trabalho de 
parto. - Já pensou na canseira que deve ser pra o médico?

Olá Doutora Débora,

Eu sei que você é muito ocupada e provavelmente não tem tempo para ler cartas de ex-pacientes, mas mesmo assim escrevi, quem sabe bate uma curiosidade.

Sobre a precariedade da situação de médicas e médicos na assistência obstétrica brasileira, Ricardo Herbert Jones (2006), um dos obstetras do movimento pelo parto humanizado que atua nas redes sociais, contando com cerca de 5000 seguidoras/es no Facebook, além de assinar o blog Orelhas de vidro ${ }^{37}$, escreveu recentemente sobre a "desumanização dos cuidadores":38

O tema da assistência privada ao parto é tratado por nós nas redes sociais há no mínimo 17 anos. [...]. Quando vejo médicos que resolvem atender por convênios o resultado é arriscado, para dizer o mínimo: atendem uma demanda de 15 a 20 partos por mês. Com esse tipo de fluxo - que desrespeita o princípio da humanização dos cuidadores - a QUALIDADE do trabalho despenca. É impossível atender um parto quando o obstetra desumaniza-se, quando ele trabalha demais, está cansado, esgotado, com energias exauridas e com seu raciocínio prejudicado pelo acúmulo de trabalho. A solução seria atender um número limitado de pacientes, e para mim este valor chega a $4-6$ por mês, que nos oportuniza um trabalho quase artesanal. Dá para cancelar consultório, atender sem angústia de tempo, indicar cesariana corretamente (e não porque está dormindo e/ou estafado), fazer visitas domiciliares pré e pós parto, atender o puerpério em domicílio (evitando que um bebê de 7 dias saia à rua para respirar escapamento de ônibus), demorar nas consultas etc. Tudo isso é impossível de fazer atendendo 18 partos por mês.

Como teria dito Hannah Arendt (2008, p. 331), compreender não é o mesmo que perdoar, mas é um passo indispensável quando se busca mudança numa realidade onde a atuação de profissionais da assistência é central. Portanto o foco no ser humano deve necessariamente contemplar também essas/es profissionais. Na mesma nota, Jones (2006) defende:

Uma das soluções é acabar com esse paradigma que prevê a existência de um médico particular atendendo partos de suas pacientes privadas. Esse é um modelo falido e tem que acabar. Ele é responsável - entre outros fatores pelas taxas abusivas e vexatórias de cesarianas no mundo ocidental, em especial nos países satélites dos Estados Unidos. Esse modelo iatrocêntrico, etiocêntrico e hospitalocêntrico (centrado no médico, na doença e no hospital) precisa terminar. O futuro nos reserva, em curto prazo, as Casas de Parto e os hospitais humanizados com trabalho interdisciplinar.

Ainda falta vontade política e organização social, mas .... por que não

\footnotetext{
${ }^{37}$ https://orelhasdevidro.com.

${ }^{38}$ https://orelhasdevidro.com/2016/10/20/atendimentos-privados/.
} 
podemos nos manter otimistas diante do tanto que já conquistamos?

Concordo com Jones em sua defesa de um modelo que priorize as Casas de Parto e hospitais com trabalho interdisciplinar, e defendo que isso deva ser um modelo de atendimento público e gratuito, garantido pelo SUS como um direito universal. Entendo que isso é fundamental para que a humanização não seja algo restringido a um grupo de privilegiadas/os.

Com relação à/ao profissional humanizada/o, a identificação representada nas cartas e relatos corresponde a alguém confiável e merecedor/a de elogios por atuar com serenidade, amor, respeito, buscando equilibrar sua prática por meio da combinação de técnicas modernas com as vantagens da tradição das parteiras. Um/a profissional humanizada/o, identificada/o pelas autoras com base em suas expectativas, mas também devido a experiências relatadas, diria palavras mansas, acalmaria, promoveria a liberdade de escolha e decisão da mulher em trabalho de parto, agiria com delicadeza, segurança, respeito e ética, tratando a mulher com dignidade. Por ter encontrado alguém que agia assim, Dandara agradece, em (84):

(84) Agradeço muito por ter sido delicado comigo no meu momento de fragilidade, por garantir meu parto normal respeitoso do início ao fim. Por ser um médico digno de ser chamado de médico humanizado.

\subsection{Como são representados os contextos do pré-natal e do nascimento?}

Os contextos de pré-natal e nascimento são os períodos dos enganos, das dúvidas e da maior parte dos medos, e são representados sobretudo em torno da oposição casa-hospital, sem que se deixe de mencionar questões conjunturais como seriam as supostas deficiências do SUS e a dependência generalizada de planos de saúde que limitariam o escopo para busca de profissionais para o atendimento do parto e do pré-natal. Exemplos disso são as falas de Dandara, em (85), de Tânia, em (86), de Laura, em (87), e de Elena, em (88):

Gostaria de agradecer por ter acompanhado o meu pré-natal com tanto respeito, sem os infinitos toques do SUS e acompanhado o meu parto sem enema, tricotomia, kristeller, estribos, fórceps, episiotomia e anestesia, por permitir que inclinasse a cama, por permitir o acesso ao meu marido, respeitando o momento do rompimento da bolsa e permitindo que meu filhote se encaixasse na hora dele.

(86) Sem falar que, não sei você, mas eu tenho pavor de hospital, pra mim é um local de doenças, pessoas estranhas (e muitas vezes arredias), agulhas, álcool, frio, macas duras... ainda mais no SUS. Não iria pro hospital sem necessidade, só isso. 
O meu plano só cobria um hospital para partos em toda a [cidade] e esse hospital não liberava a presença do pai nem no pré-parto e nem durante o parto.

Fiz meu pré-natal com você, já que uma amiga que tinha o mesmo plano de saúde e estava grávida me disse que era uma das médicas que estava em uma tal lista de obstetras que faziam partos normais.

Independentemente da opção pela casa ou pelo hospital, em ambos os casos, é relatada a dificuldade em encontrar profissionais reconhecidas/os como humanizadas/os para o pré-natal e para o parto. Apesar das trocas entre mulheres e das escolhas justificadas por recomendações, mesmo no caso das mulheres informadas, a tentativa de buscar um atendimento digno, ético e profissional foi representada quase sempre como uma loteria com poucas chances de acerto. Tânia trata disso em (89), a seguir:

Fui atrás de parteira, GO ou Enf. Obstetra que pudesse acompanhar meu parto, mesmo que fosse para vir de outra cidade. E tava bem complicado, as semanas iam passando, o parto se tornando próximo e nada... Quando encontrava alguém essa pessoa não poderia vir, ou teria parto na mesma época, ou só se eu fosse pra tal cidade... e eu querendo ter meu parto aqui, na minha casa mesmo.

Isso sugere a fragilidade da luta individual frente a um sistema marcado pela violência institucional, em que a ação individual sofre o forte constrangimento de uma estrutura social violenta, associada a crenças e instituições que reificam essa violência. Mas se um voluntarismo heroico e romantizado se constitui numa falsa promessa, as redes de mulheres associadas se apresentam como um elemento eficaz de resistência nesse contexto. O compartilhar de histórias, como acontece por meio da publicização dos relatos e cartas analisados, certamente fortalece essas redes e serve de suporte tanto para mulheres usuárias da assistência quanto para profissionais de saúde empenhadas/os na humanização do atendimento e consequente melhora da qualidade e dignidade também em suas vidas, no exercício de suas profissões.

6.4. Como se relacionam essas representações/identificações com a conjuntura mais ampla em que elas acontecem ou das quais elas resultam?

No capítulo de contextualização, mencionei o histórico recente de hospitalização da assistência ao parto levado a cabo principalmente nas regiões urbanas do Brasil. Essa evolução ocorreu mais intensamente na segunda metade do século XX, sendo mais um aspecto do desenvolvimento da modernidade ocidental, na qual prevalece a valorização da técnica e da 
intervenção em detrimento dos conhecimentos tradicionais, especialmente daqueles cujas portadoras eram mulheres em comunidades e parteiras tradicionais.

A formação médica ocorre em universidades eurocêntricas, androcêntricas e misóginas por vício de nascimento ${ }^{39}$, orientadas pelo método, pretensamente objetivo, com a valorização da especialização em detrimento de um saber holístico, e de uma racionalidade que menospreza os aspectos emocionais e espirituais dos seres humanos, além de se pautar por uma visão pessimista do corpo feminino, que faz com que profissionais desacreditem da mulher quanto ao potencial para parir. Isso se materializa discursivamente, por exemplo, na representação de Amanda sobre o que teria ouvido de Dr. Ricardo ao mencionar sua vontade de parir naturalmente, em (90):

(90) Parto normal? - acho muito difícil você conseguir ter parto normal. Você, além de ser primigesta, já tem 36 anos. Provavelmente nem vai entrar em trabalho de parto!

Ou também no fragmento da carta de Aída, no fragmento em (24), retomado aqui da seção 3.9, no qual o aconselhamento para a cesariana se justificaria por uma suposta inadequação do corpo dela:

(24) Te liguei de manhã, avisando que perdi o tampão e sentia algumas cólicas. Você me mandou ir para a [hospital]. Fui e estava em pródromos de trabalho de parto. A enfermeira me examinou e depois disse que você viria falar comigo pessoalmente. Cerca de 40 minutos depois você chegou e disse que meu colo era grosso, duro e posterior, o que significaria um longo trabalho de parto, e que poderia acarretar em sofrimento fetal para minha filha. Aconselhou uma cesárea imediata, para assim evitar que ela nascesse mal.

O sistema capitalista vigente, no qual as relações de trabalho, também das/os profissionais da medicina, se pautam pela mais valia e são regidas por interesses econômicos, antes que por interesses comunitários e humanitários, também tem impacto inevitável na assistência obstétrica e contribui para a sedimentação de uma prática, e consequentemente, de um discurso violento, como o que Tânia chamou de "terrorismo do parto normal", que (re)constitui constantemente os padrões questionáveis dessa assistência marcada pela violência institucional, que se dá também discursivamente. Aspectos relacionados a esses interesses econômicos também aparecem nas representações, frequentemente associados à questão do plano de saúde,

\footnotetext{
${ }^{39}$ Lembre-se aqui a menção ao quarto epistemicídio fundador da universidade ocidental e colonizadora, a queima dos corpos das mulheres como forma de destruição de seus saberes (Grosfoguel, 2016, p. 42).
} 
o que podemos relacionar à falta de um atendimento digno, universal e gratuito. Laura, por exemplo, no excerto em (21), analisado na seção 3.8, menciona as limitações impostas pelo plano de saúde que motivaram sua opção pela cesárea.

(21) Bom! Por eu não ter me informado antes, meu filho nasceu de cesariana. $\mathrm{O}$ meu plano só cobria um hospital para partos em toda a [cidade] e esse hospital não liberava a presença do pai nem no pré-parto e nem durante o parto. No pré-parto eu teria de ficar em uma sala junto com várias outras mulheres passando pela mesma situação. Durante o parto seríamos eu, meu filho e a tropa médica.

Esse sistema econômico difere sobremaneira do sistema de dádivas de Mauss mencionado por Santos (2010, p. 84), conforme o qual outra forma possível de organização é vislumbrada:

Tal entendimento faz sentido ao relacionar a oferta das práticas de cuidado das parteiras às noções de dádiva, de aliança, peculiar ao modelo tradicional que o ancora e promove, por considerar que cada um desses compromissos ou obrigações cria um laço de energia espiritual entre as pessoas envolvidas na troca de dádiva. Atribuindo-lhe a existência de uma força que tem relação com $\mathrm{o}$ ato de dar e com a coisa dada, denotando a vinculação de almas e à dimensão espiritual, ou à sua expressão simbólica, diferente da noção de troca mercantil e econômica, como na atualidade se compreende.

A medicina e a hospitalização são muito associadas aos melhores índices na qualidade de vida da população das sociedades industriais ocidentais, embora de fato essa melhora se deva antes a políticas de saneamento (Tew, 1990, p. viii). A crença no poder da classe médica se baseia antes num misticismo lendário e numa crença na ciência que não se justifica, especialmente quando verificamos que os procedimentos carecem frequentemente de respaldo e se situam numa zona cinza, pois ao mesmo tempo em que desprezam ou desconsideram conhecimentos tradicionais frequentemente carecem de evidências científicas, baseando-se, portanto, em 'crendices cientificamente expressas' quanto a sua validade. Na representação na carta de Dandara, analisada na seção 5.2, encontra-se uma correspondência com esse quadro, nemeadamente, no fragmento em (91), ao mencionar a delegação de toda responsabilidade e protagonismo a um/a médica/o:

(91) Se eu fosse religiosa diria que uma mulher que delega ao médico toda a responsabilidade e protagonismo do seu parto estaria acreditando mais no médico que em Deus. E o mesmo diria ao médico que admite que isto aconteça, ele pensa ser melhor que Deus. 
Uma medicina baseada em evidências corresponderia ao "uso consciencioso, explícito e judicioso das melhores evidências científicas correntemente disponíveis para tomar decisões relativas ao cuidado de pacientes individuais" (Sackett, et al. apud Amorim, 2014). ${ }^{40}$. E uma medicina que atendesse o desejo por médicas/os parteiras/os não poderia desconsiderar a expectativa de Santos (2010, p. 184) de

que o olhar de novas pesquisas e pesquisadoras (es) seja redimensionador, permitindo ressignificar a importância das racionalidades e construções engendradas pelas parteiras, por acreditar que a dimensão científica deve andar junto com o saber tradicional.

Mesmo porque, como também afirma Santos (2010, p. 124 e 182),

[a] construção do conhecimento das parteiras tradicionais é um saber considerado um patrimônio humano e cultura imaterial, fruto de diversas culturas, mantido e transmitido oralmente de geração em geração. São ações relacionadas às dimensões do campo afetivo, emocional, psicológico, que se revelam como "técnicas que compõem tecnologias, lenta e gradativamente sendo construída na observação, experimentação e, sobretudo, na vivência histórica e sociocultural".

$[\ldots]$

Hoje, é possível relacionar como as práticas empíricas das parteiras estão na base da pirâmide da ciência biomédica, como observação que se verifica em suas narrativas, ao detalharem sobre alguns utensílios - o fio de algodão, a tesoura, o prato, o garfo ou a faca, o fogo em brasa, usados no procedimento para cortar e queimar os vasos sanguíneos do coto umbilical. Esses métodos tradicionais se constituem em indícios e semelhanças para o processo de cauterização sanguínea usado como tecnologia médico-cirúrgica dura, resultando na criação do bisturi elétrico.

Ou seja, embora o conhecimento das parteiras seja um patrimônio cultural da humanidade, construído historicamente, e que esse conhecimento esteja na base da ciência biomédica vigente, os aspectos que nesse processo de assimilação foram desconsiderados ou entendidos como supérfluos, como aspectos instintivos, emocionais e espirituais do parto, parecem ser justamente o que falta à medicina obstétrica para que seja humanizada. ${ }^{41}$

\footnotetext{
$40 \mathrm{Na}$ aula "Da Medicina Baseada em Evidências à Pesquisa Translacional: refletindo sobre paradigmas", disponibilizada em seu blog Estuda, Melania, estuda.

${ }^{41}$ Especialmente num país como o Brasil, de acordo com estudo da organização não-governamental Save The Children (2016) divulgado recentemente, o pior país para ser menina na América do Sul, consideradas aí, entre outras coisas, as taxas de casamentos e maternidade infantis e de mortalidade materna. $\mathrm{Na} 102^{a}$ posição, apesar de ser a $9^{a}$ maior economia do mundo, o Brasil está apenas três posições mais bem colocado no quesito da qualidade de vida das meninas que o Haiti, $138^{\text {a }}$ economia do mundo.
} 
Na identificação de seu obstetra, quando o chama "médico parteiro", Lívia denota no fragmento em (50), retomado aqui da seção 4.2, o anseio por uma ciência biomédica que, além da técnica, também valorize a humanidade no atendimento.

(50) Com 32 semanas e alguns amigos nos guiando, conhecemos a nossa obstetriz e aquele que viria a ser nosso médico parteiro. A sensação ao sair das consultas eu nunca vou esquecer... é difícil achar palavras pra descrever, mas foi como respirar novos ares. Pela primeira vez eu senti muito prazer em estar grávida. Tudo fez sentido, pois minha vontade seria respeitada, afinal de contas, alguém estava me ouvindo. Não precisou muita conversa pra que eu entendesse o sentido da humanização, não só do parto, mas de todo o processo até chegarmos a ele. A obstetriz é uma fonte de energia e serenidade. O médico parteiro, um ser humano apaixonante. Ambos amam o que fazem e fazem com respeito.

6.5. Como se (re)produz e/ou se minimiza discursivamente o problema da violência obstétrica considerado o contexto mais amplo em que ela se insere?

A (re)produção discursiva da violência obstétrica se dá de distintas formas, que compreendem o dizer e o silenciar, o dizível e o indizível. Quando repetimos padrões de fala nos quais o protagonismo é atribuído à/ao profissional da assistência, quando por meio de diminutivos minimizamos a intensidade das intervenções sofridas, quando deixamos de comunicar a violência sofrida, quando não reconhecemos o teor público do que se acostumou relegar ao plano do íntimo e do pessoal, quando repetimos irrefletidamente modos cristalizados e normalizadores de fala, em lugar de denormalizar, de escandalizar discursivamente os padrões violentos do tratamento com as mulheres, também na assistência obstétrica, contribuímos para a reprodução dos padrões violentos que têm se estabelecido nessa assistência.

Por outro lado, visto desde uma perspectiva discursiva, a minimização desse problema se dá, exemplarmente, por meio das trocas concretizadas nos relatos e cartas que vêm sendo escritas por mulheres que se valem do recurso que é o poder de escrever, para comunicar, escandalizar, denormalizar padrões violentos, compartilhando histórias de dor e de regozijo, num intento de resistir e de ressiginificar padrões estabelecidos e não questionados, como o peso do medo ou da dor para a mulher que espera e que pare.

Questionamentos diante de comportamentos pouco compreensíveis, como aquele da GO que apesar de só fazer o pré-natal no posto de saúde, "sem ganhar nada com isso", ainda assim se afilia ao "terrorismo do parto normal", colaborando para a reprodução de um discurso violento, também têm o efeito de mudar o fluxo do discurso. Perceber que a questão é sistêmica e que 
não pode ser abordada em termos pessoais, como se tratasse de decisões meramente individuais, motivadas por atitudes cunhadas em maldade ou bondade de pessoas singulares, mas antes em algo que diz respeito a estruturas sociais constrangedoras da ação social, que exigem ações orquestradas e não um voluntarismo individual, também contribui para a mudança discursiva que reverte a situação da violência institucionalizada. Entendo com Hannah Arendt (2001, p. 36) que "o poder corresponde à habilidade humana não apenas para agir, mas para agir em concerto. O poder nunca é propriedade de um indivíduo; pertence a um grupo e permanece em existência apenas na medida em que o grupo conserva-se unido". Assim sendo, retomar o poder sobre nossos corpos, depende também de ações coletivas, que são, em grande medida, discursivas.

Apresentar resultados analíticos que evidenciam o simbolismo coletivo, chamando atenção para metáforas que são figuras [de linguagem], imagens que "valem mais que mil palavras", de forma a didaticamente escandalizar padrões aceitos como normais (circos de horrores, obstetrícia de linha de montagem, médicas/os atuando como tropas militares, sistema de atenção mecanizado, terrorismo do parto normal, entre outras imagens possíveis...) também pode influenciar o discurso que orienta a prática, ajudando a combater a violência institucionalizada. Ademais, o simbolismo que promove novos padrões sonhos e possibilidades, como no caso da ideia de parto como montanha russa, da existência de portinha para o parto humanizado, também pode ser visto como uma contribuição na quebra de paradigmas violentos. Coragem para devolver a voz ao corpo, para ouvir sobre os saberes e as características humanas silenciadas e desvalorizadas no curso da história acadêmica ocidental, tais como o lado emocional, o espiritual, o místico, também parece ser um grande passo nesse sentido. Assim como pode ser a humildade para o reconhecimento das ignorâncias e dos limites da ação humana, pois quem sabe assim possamos nos ver obrigadas/os a simplesmente ter mais fé na vida, especialmente no momento em que ela brota do ventre de uma mulher.

Outra contribuição importante seria ressignificar os dispositivos casa e hospital, comunicando discursivamente essa mudança, que acontece quando mulheres percebem os valores do partejar tradicional e retomam o parto domiciliar, como relata Santos (2010, p. 94) sobre o movimento de volta para casa:

Hoje em dia, essa característica vem sendo percebida como alvo para as mulheres que vivem o processo reprodutivo, ancorando os variados $\mathrm{e}$ complexos sentidos do partejar, ressignificando o parto domiciliar, as parteiras, os rituais e práticas que compõem o ofício de partejar nos domicílios 
urbanos.

Pensar e refletir constantemente sobre a própria prática e sobre as consequências de cada ato no sentido de, reconhecendo a banalidade do mal, procurar evitar o risco de agir violentamente por mero descuido também me parece estratégico na minimização da violência. Atentar para as nossas próprias escolhas lexicais, para a forma como reproduzimos ou descontruímos um discurso sobre o mundo seria uma forma de agir assim, por exemplo sendo parcimoniosas/os com o discurso do risco e do medo durante a gestação e procurando ser mensageiras/os do sonho possível de uma assistência digna. 


\section{Considerações finais.}

Não é sobre chegar no topo do mundo e saber que venceu,
é sobre escalar e sentir que o caminho te fortaleceu.
(Ana Vilela)

A uns trezentos ou quatrocentos metros da Pirâmide me inclinei, peguei um punhado de areia, deixei-o cair silenciosamente um pouco mais longe e disse em voz baixa: Estou modificando o Saara. O fato era mínimo, mas essas palavras pouco engenhosas eram exatas e pensei que havia sido necessária toda minha vida para que eu pudesse dizê-las.

(Jorge Luis Borges)

Apesar de reconhecer as limitações deste estudo, não posso deixar de afirmar que o caminho me tenha fortalecido enquanto mulher que, por reconhecer que o poder pertence ao grupo (Arendt, 2001, p. 36), assume sua própria responsabilidade no grupo de mulheres empenhadas na busca e/ou na manutenção do poder para garantir nossos direitos humanos, sexuais e reprodutivos.

Um dos ganhos pessoais que obtive nessa caminhada, ou nessa escalada, foi ampliar meu horizonte de compreensão sobre a complexidade de um problema cujo sintoma mais evidente pode ser considerado nossa taxa de cesarianas acima de 50\%, uma das mais elevadas do mundo. Foi perceber que não se trata de defender o parto natural e de condenar a cesárea; trata-se antes de procurar compreender o porquê de as mulheres serem tão desrespeitadas e violentadas justamente num dos momentos de maior grandiosidade e de vulnerabilidade que podemos experimentar. Foi perceber que isso tem a ver com a falta de garantia generalizada de direitos humanos, sexuais e reprodutivos das mulheres em nosso país.

Ademais, outro resultado desse processo que considero importante foi perceber que uma visão maniqueísta e personalista, que separa o mundo entre médicas/os vilãs/ãos e pacientes vítimas indefesas e impotentes, como se a violência praticada fosse não somente banal, mas também intencional e irresistível, provavelmente não nos ajudará avançar no combate à violência de maneira sistêmica. Com minha pesquisa, pude perceber que é importante buscar entender como a violência no encontro de seres humanos prejudica também a qualidade de vida de profissionais da saúde. Buscar entender como essas/es profissionais também sofrem as consequências de um esquema de trabalho precarizado, cunhado numa formação médica que também pode ser violenta (Castro, 2014, p. 169), ou cujos fundamentos resultam de uma evolução histórica baseada em violência e em relações de dominação (Grossfogel, 2016), parece-me ser o caminho 
mais adequado para que possamos desconstruir verdades históricas que têm justificado a violência institucionalizada contra as mulheres.

Essa compreensão não equivale, contudo, a perdoar ou poupar cada uma e cada um de assumir suas responsabilidades na (re)construção ou na manutenção das estruturas sociais vigentes, ainda que se reconheça as restrições que ela impõe à ação social, individual ou coletiva. Pois, se a estrutura constrange, ela também sofre os efeitos dessa ação, sendo por ela constantemente transformada. Tentar compreender também as/os agressoras/es, e suas motivações, pode ser o caminho para não ignorar o ser humano em cada um/a delas/es e para buscar o diálogo, na busca de uma solução efetiva. Não acredito ser possível alcançar essa solução de maneira tão harmônica que o conflito, a denúncia, a perda e alguma dor não façam parte do processo. Entretanto creio que um tal processo de (re)identificação feminina e profissional possa, sim, diminuir a propensão de médicas e médicos a incorrer no equívoco de pensar "serem melhores que Deus", como na hipótese aventada por Dandara, e, concomitante e complementarmente, aumentar a coragem das mulheres para se (re)apropriarem de seus próprios corpos.

Buscar um equilíbrio em reconhecer a responsabilidade e os papeis de cada um, mulheres e profissionais, sem culpabilização ou responsabilização descompensada de nenhum dos lados, me parece ser um bom caminho. Isso não significa desconsiderar a assimetria na relação mulher-profissional, mas buscar minimizá-la promovendo a necessidade de que as mulheres sejam ouvidas, que possam verbalizar, expressar seus afetos, julgamentos e apreciações. Agir assim não significa desmerecer o peso e o lugar de comportamentos violentos institucionalizados como pedra no caminho de um voluntarismo romantizado, que acaba por ser mais uma forma de violência contra a mulher, muitas vezes culpabilizada dentro do próprio movimento pelo insucesso de seu parto ou pelas agressões sofridas.

Essencial nesse intento é a necessidade de vigilância e reflexão constante, para que não reproduzamos, também no âmbito de nossa luta supostamente libertária, comportamentos opressores e violentos, que poderiam nos levar a contribuir, mesmo sem querer ou perceber, com a violência que pretendemos minimizar. Não buscar entender a razão que leva uma mulher a optar por uma cesariana, atacando-a por essa opção, que, tantas vezes, pode ter sido também um ato de resistência, uma "busca por dignidade" (Diniz, 2009, p. 321), por exemplo, não deveria acontecer num movimento que defende a mulher e seus direitos, inclusive à autonomia sobre o próprio corpo. Julgar a mulher que confia em sua/seu médica/o e acaba sendo vítima de violência, julgá-la por não ter buscado uma "equipe humanizada", desconsiderando a força das 
estruturas, do discurso, das crenças familiares e, sobretudo a escassez e o custo dessa "oferta humanizada" não deveria acontecer numa luta libertária.

Uma das grandes questões que levo comigo atualmente diz respeito à "humanização para quem?" Quais os rumos que queremos dar a nosso movimento? Queremos contratar "equipes humanizadas" ou queremos ter acesso a um atendimento digno, ético, profissional, universal, público e gratuito? Lutamos por privilégios ou por direitos? O meu questionamento ecoa aquele ouvido por Herbert Jones (2016b), ainda em 2002, durante uma palestra em Salvador:

Dr, é muito bonito o seu relato das transformações no parto que ocorrem impulsionadas pelas redes sociais, mas minha pergunta simples é a seguinte: essas vantagens inquestionáveis do parto humanizado são para uma casta de mulheres de classe média que tem tempo e dinheiro para navegar na Internet ou ela também vai atingir a mulher negra e pobre da periferia de Salvador?

Ao comentar ainda esse questionamento, Jones (2016b) nos relembra esperançosamente os avanços já alcançados na assistência pública e gratuita, nos fazendo constatar que eles são possíveis. Considero, contudo, importante saber que esses avanços certamente não se ampliarão sem um engajamento consciente nessa pauta, por esse sonho:

A migração da humanização do nascimento para o serviço público e o SUS é o caminho natural dessa revolução. As experiências exitosas do Sofia Feldman, Hospital Conceição, Sapopemba, Davi Capistrano no Realengo, Casa Ângela entre outros, mostra que o caminho é a disseminação da mensagem para toda a população. Quem viver verá: o que hoje parece um sonho em pouco tempo se tornará realidade.

Ademais, acho que qualquer avanço passa por uma decolonização no reconhecimento dos saberes e de sua legitimidade. A humanização passa por dessilenciar os conhecimentos tradicionais corporificados na figura das parteiras tradicionais. Sua (re)valorização enquanto mulheres, sábias e agentes sociais é urgente. As parteiras são um símbolo da (r)existência da mulher que sabe, da mulher que pare e apara, da mulher que sobrevive(u) ao epistemicídio nas fogueiras ou no fogo cotidiano da alta taxa de feminicídios que faz com que o Brasil seja o quinto colocado no ranking dos países que mais matam mulheres no mundo. Infelizmente, a violência não é só obstétrica, mas nós parimos, partejamos e (r)existimos, pois onde há violência, também há (r)existência. Como lembra Santos (2010, p. 86), “ainda existem aquelas mulheres que se disponibilizam ao parto domiciliar como ritual e como resistência". 
Tanto a violência quanto à (r)existência também são discursivas e se concretizam em textos, orais ou escritos, como são os relatos e cartas que analisei. Diante desse fato, que não questionava, havia para mim, sim, durante esta pesquisa, a dúvida quanto a validade ou a necessidade de uma análise discursiva crítica para chegar a enunciados referentes ao feixe discursivo em foco. Eu me perguntava inicialmente se a uma mera leitura não daria conta dos mesmos resultados que eu alcançaria caso usasse as ferramentas propostas pela ADC. Depois de percorrer esse caminho nos últimos seis anos, nos quais li e reli inúmeras vezes cada um dos relatos e cartas analisados, afirmo com tranquilidade que, apesar de todas as leituras prévias, a análise sempre era profícua e reveladora, me ajudando a perceber nuanças que teriam me escapado, ou que já tinham me escapado, mesmo com toda a leitura anterior.

Dito isso, finalizo ressaltando que o principal objetivo que entendo ter alcançado com este trabalho foi a possibilidade de conciliar a pesquisa acadêmica interdisciplinar com um engajamento político em prol de uma vida melhor para todas as mulheres, e consequentemente, para todas as pessoas a sua volta, pois, como diria Paulo Freire, nos libertando, também libertamos nossos opressores. Embora reconheça os limites de meu trabalho, acredito, sim, que a cada vez que falei sobre ele em ambientes onde falar sobre o parto, sobre a violência obstétrica e sobre a (r)existência das mulheres não fosse algo corriqueiro, dado, esperado ou quiçá mesmo desejado, eu estava levantando areia e modificando o Saara. E ele certamente ainda precisa ser muito modificado, entretanto, certamente não é mais o mesmo depois de eu ter mexido meu punhado de areia. Podemos. 


\section{Referências bibliográficas.}

AGUIAR, Janaína Marques de. Violência institucional em maternidades públicas: hostilidade ao invés de acolhimento como uma questão de gênero. Tese (Doutorado em Ciências) Faculdade de Medicina, Departamento de Medicina Preventiva, Universidade de São Paulo, 2010.

ALBERTI, Verena. Indivíduo e biografia na história oral. Rio de Janeiro: CPDOC, 2000. Disponível em http://www.cpdoc.fgv.br/Producao_intelectual/htm/tp_download.htm, acesso em 19 de maio de 2007.

ALBERTI, Verena. Literatura e autobiografia: a questão do sujeito na narrativa. Revista Estudos Históricos, Rio de Janeiro, v. 4, n. 7, p. 66-81, jul. 1991. ISSN 2178-1494. Disponível em http://bibliotecadigital.fgv.br/ojs/index.php/reh/article/view/2313, acesso em 25 de setembro de 2016.

ALBERTI, Verena. Narrativas na história oral. In Anais eletrônicos do Simpósio Nacional de História João Pessoa: ANPUH-PB, 2003. Disponível em http://www.cpdoc.fgv.br/Producao_intelectual/htm/tp_download.htm, acesso em 07 de setembro de 2009.

AMADO, Janaína \& FERREIRA, Marieta de Moraes. Apresentação. In Usos e Abusos da História Oral. Rio de Janeiro: FGV, 2001. p. vii-xxv.

AMORIM, Melania. Da Medicina Baseada em Evidências à Pesquisa Translacional: refletindo sobre paradigmas. Aula disponibilizada em blog, 2014. Disponível em https://www.dropbox.com/s/fd7mf72yg1xzahd/DA\%20MBE\%20\%C3\%80\%20PESQU ISA\%20TRANSLACIONAL\%20REFLETINDO\%20SOBRE\%20PARADIGMAS\%20 2014.pdf, acesso em 23 de outubro de 2016.

AMORIM, Melania. Estudando a cesárea desnecessária: resultados do Global Survey (OMS). Disponível em http://estudamelania.blogspot.de/2012/11/estudando-cesareadesnecessaria.html, acesso em 15 de julho de 2014.

AMORIM, Melania. Mecônio é sinal de sofrimento fetal? In Para pais, 2015. Disponível em http://www.ebc.com.br/infantil/para-pais/2015/01/meconio-e-sinal-de-sofrimento-fetal, acesso em 03 de agosto de 2016.

ANGROSINO, Michael. Etnografia e Observação Participante. Porto Alegre: Artmed, 2009. 
ARENDT, Hannah. Compreensão e política (As dificuldades da compreensão). In. Compreender: formação, exílio e totalitarismo. Belo Horizonte (BH): Companhia das Letras/Editora UFMG; 2008;

ARENDT, Hannah. Poder e violência. Rio de Janeiro: Relume Dumará, 2001. pp. 81-94

AUSTIN, John L. How to do Things with words. Harvard: University Press, 1975.

BATALHA, Elisa. Parto e nascimento com cidadania. Radis: comunicação e saúde. Escola Nacional de Saúde Pública Sergio Arouca (ENSP), nº 117, maio, 2012.

BAUMAN, Zygmunt. Medo líquido; tradução, Carlos Alberto Medeiros. Rio de Janeiro: Jorge Zahar, 2008.

BECK, Ulrich. Risikogesellschaft: auf dem Weg in eine andere Moderne. Edition Suhrkamp, Bd. 1365. Frankfurt am Main: Suhrkamp, 1986.

BENEVIDES, Maria Victória. Violência policial e democracia podem conviver? In Lua Nova, São Paulo, v. 1, n. 4, p. 25-26, Mar. 1985. Disponível em http://www.scielo.br/scielo.php?script=sci_arttext\&pid=S0102$64451985000100008 \& \operatorname{lng}=$ en\&nrm=iso, acesso em 26 de julho de 2016.

BHASKAR, Roy. The possibility of Naturalism. A philosophical critique of the contemporary Human Sciences. Hemel Hempstead: Harvester Wheatsheaf, 1989.

BLUHM, Claudia; DEISSLER, Dirk; SCHARLOTH, Joachim; STUKENBROCK, Anja. Linguistische Diskursanalyse: Überblick, Probleme, Perspektiven. In Sprache und Literatur in Wissenschaft und Unterricht 88, S. 3-19 Disponível em http://www.scharloth.com/publikationen/scharloth_diskursanalyse.pdf, Acesso 19 de agosto de 2016.

BOURDIEU, Pierre. A ilusão biográfica. In AMADO, Janaína \& FERREIRA, Marieta de Moraes (orgs.). Usos e Abusos da História Oral. Rio de Janeiro: FGV, 2001. pp. 183-191

BRAH, Avtar. Diferença, diversidade, diferenciação. In Cad. Pagu, Campinas , n. 26, p. 329376, junho, $2006 \quad$. $\quad$ Disponível em http://www.scielo.br/scielo.php?script=sci_arttext\&pid=S0104$83332006000100014 \& \operatorname{lng}=$ en\&nrm=iso, acesso em 27 de agosto de 2016. 
BRASIL. Fiocruz pesquisa preferência das brasileiras pela cesariana. In Portal da Saúde SUS. 07/12/2012. Disponível em http://www.brasil.gov.br/saude/2012/02/fiocruz-pesquisaaumento-de-cesarianas-no-brasil, acesso em 15 de julho de 2013.

BRASIL. Governo manifesta solidariedade a Adelir Carmem Lemos de Goes. 2014. Disponível em: http://www.sdh.gov.br/noticias/2014/abril/governo-manifesta-solidariedade-aadelir-carmem-lemos-de-goes, acesso em 17 de julho de 2016.

BRASIL. Humanização do parto e do nascimento. Ministério da Saúde. Universidade Estadual do Ceará. Brasília: Ministério da Saúde, 2014.

BRASIL. Livro da parteira tradicional. Ministério da Saúde, Secretaria de Atenção à Saúde, Departamento de Ações Programáticas Estratégicas. Brasília: Ministério da Saúde, 2012.

BRASIL. Parto, aborto e puerpério: assistência humanizada à mulher. Brasília: Ministério da Saúde, 2001.

BRASIL. Saúde Brasil 2009: uma análise da situação de saúde e da agenda nacional e internacional de prioridades em saúde. Ministério da Saúde, Secretaria de Vigilância em Saúde, Departamento de Análise de Situação de Saúde. - Brasília: Ministério da Saúde, 2010.

BRITO, Annie Mehes Maldonado; CAMARGO, Brigido Vizeu. Representações sociais, crenças e comportamentos de saúde: um estudo comparativo entre homens e mulheres. Temas psicol., Ribeirão Preto , v. 19, n. 1, p. 283-303, jun. 2011. Disponível em http://pepsic.bvsalud.org/scielo.php?script=sci_arttext\&pid=S1413389X2011000100023\&lng=pt\&nrm=iso, acesso em 11 de agosto de 2016.

BRUM, Eliane. A potência de Adelir: Que dogmas tão profundos a gestante de Torres feriu para ter seu corpo violado pelo Estado na calada da noite. In El País, Edição Brasil, 14 de abril. Disponível em http://brasil.elpais.com/brasil/2014/04/14/opinion/1397481297_943876.html, acesso em 22 de novembro de 2014.

CALDAS-COULTHARD, Carmen Rosa. Da Análise do Discurso à Análise Crítica do Discurso: Introduzindo Conceitos. In CALDAS-COULTHARD, Carmen Rosa \& SCLIAR-CABRAL, Leonor (orgs.). Desvendando Discursos: conceitos básicos. Florianópolis: Editora da UFSC, 2008. 
CARVALHO, Fátima. O parto roubado é um conceito político de resistência. 2014. Disponível em http://arquivo.geledes.org.br/em-debate/fatima-oliveira/24280-o-parto-roubado-eum-conceito-politico-de-resistencia-por-fatima-oliveira, acesso em 15 de julho de 2014.

CASTELLS, Manuel. O poder da identidade. São Paulo: Paz e terra, 1999.

CASTRO, Maria da Graça de; ANDRADE, Tânia M. Ramos; MULLER, Marisa C. Conceito mente e corpo através da História. In Psicologia em estudo, Maringá , v. 11, n. 1, p. 3943, abril de 2006. Disponível em http://www.scielo.br/scielo.php?script=sci_arttext\&pid=S1413$73722006000100005 \& \operatorname{lng}=$ en\&nrm=iso, acesso em 28 de julho de 2016.

CASTRO, Roberto. Génesis y práctica del habitus médico autoritario en México. In Rev. Mex. Sociol, México, v. 76, n. 2, p. 167-197, jun. 2014. Disponível em http://www.scielo.org.mx/scielo.php?script=sci_arttext\&pid=S0188$25032014000200001 \& \operatorname{lng}=$ es\&nrm=iso, acesso em 27 de agosto 2016.

CETIN, Emil. Dispositiv/ Dispositivanalyse. In. Jäger, Siegfried/ Zimmerman, Jens (Orgs.) Lexikon Kritische Diskursanalyse. Eine Werkzeugkiste. Münster: UNRAST-Verlag, 2010.

CFM. Por oferecer maior segurança, CFM recomenda partos em ambiente hospitalar. 2012. Disponível em http://portal.cfm.org.br/index.php?option=com_content $\& v i e w=\operatorname{article} \& i d=23156 \% 3 \mathrm{Ap}$ or-oferecer-maior-seguranca-cfm-recomenda-partos-em-ambientehospitalar\&catid=3\%3Aportal\&Itemid=1, a 16 de julho de 2016.

CHOULIARAKI, Lilie \& FAIRCLOUGH, Norman. Discourse in Late Modernity. Edimburgo: Edinburgh University Press, 1999.

CRABTREE, Benjamin \& MILLER, Willian L. (orgs.). Doing qualitative research. London: Sage, 1992.

CREMERJ. CREMERJ denuncia médico que defendeu parto domiciliar. 2012a. Disponível em http://www.cremerj.com.br/informes/exibe/1285;jsessionid=Eh2981eudhIpaHIhhjzXqT z8.undefined, acesso em 13 de novembro de 2016.

CREMERJ. Resolução CREMERJ 265/12. Rio de Janeiro, 2012b.

CREMERJ. Resolução CREMERJ 266/12. Rio de Janeiro, 2012c. 
CRIZOSTOMO, Cilene Delgado; NERY, Inez Sampaio; LUZ, Maria Helena Barros. A vivência de mulheres no parto domiciliar e hospitalar. Escola Anna Nery Revista de Enfermagem, Rio de Janeiro , v. 11, n. 1, p. 98-104, mar. 2007. Disponível em $<$ http://www.scielo.br/scielo.php?script=sci_arttext\&pid=S1414$81452007000100014 \& \operatorname{lng}=$ pt\&nrm=iso, acesso em 03 de agosto de 2016.

D'GREGORIO, Rogelio Pérez. Obstetric violence: A new legal term introduced in Venezuela. International Journal of Gynecology and Obstetrics, 111, 2010. p. 201-202.

DELGADO, Lucilia de Almeida Neves. História Oral: memória, tempo, identidades. Belo Horizonte: Autêntica, 2006.

DIAS, Juliana de Freitas. A linguagem do parto: discurso, corpo, identidade. Campinas: Pontes Editora, 2015.

DIAS, Juliana de Freitas. O Renascimento do Parto: Discurso e Identidade. Tese de Doutoramento em Linguística. Departamento de Linguística, Línguas Clássicas e Vernáculas. Universidade de Brasília, 2007.

Dicionário da Língua Portuguesa com Acordo Ortográfico [em linha]. Porto: Porto Editora, 2003-2016. Disponível em http://www.infopedia.pt/dicionarios/linguaportuguesa/histeria?ic-click.

DINIZ, Simone Grilo \& CHACHAM, Alessandra Sampaio. O "corte por cima" e o "corte por baixo": o abuso de cesáreas e episiotomias em São Paulo. In Questões de Saúde Reprodutiva; I(1): 80-91. Abrasco: Rio de Janeiro, 2006.

DINIZ, Simone Grilo. Entre a técnica e os direitos humanos: possibilidades e limites da humanização da assistência ao parto. 2001 [Tese Doutorado]. Universidade de São Paulo - Faculdade de Medicina, São Paulo, 2001.

DINIZ, Simone Grilo. Gênero, saúde materna e o paradoxo perinatal. Rev. bras. crescimento desenvolv. hum., São Paulo, v. 19, n. 2, p. 313-326, ago. 2009. Disponível em http://pepsic.bvsalud.org/scielo.php?script=sci_arttext\&pid=S0104$12822009000200012 \& \operatorname{lng}=$ pt\&nrm=iso, acesso em 06 de agosto de 2016.

DOMÍNGUEZ, Daniel et al.. Etnografía virtual. Forum Qualitative Sozialforschung. Forum: Qualitative Social Research, 8(3), 2007. Disponível em http://nbnresolving.de/urn:nbn:de:0114-fqs0703E19, acesso em 14 de agosto de 2016.

FAIRCLOUGH, Norman. Analysing Discourse. London: Routledge, 2003. 
FAIRCLOUGH, Norman. Critical Discourse Analysis. Boston: Addison Wesley, 1995.

FAIRCLOUGH, Norman. Discourse e social change. Cambridge: Polity Press, 1992.

FEYERABEND, Paul. Introdução. In Contra o Método. São Paulo: UNESP, 2007. p. 31-43

FLICK, Uwe. Introdução à Coleção Pesquisa Qualitativa. 2009a. In. GIBBS, Graham. Análise de Dados Qualitativos. Porto Alegre: Artmed, 2009.

FLICK, Uwe. Sobre este livro. 2009b. In. Angrosino, Michael (2009). Etnografia e observação participante. Porto Alegre: Artmed, 2009.

FOUCAULT, Michel. O nascimento da clínica. Rio de Janeiro: Forense Universitária, 2012.

FRANZON, Ana Carolina Arruda; SENA, Ligia Moreira. Teste da violência obstétrica: Avaliação das mulheres sobre os cuidados recebidos durante internação para o parto e nascimento. Maio de 2012. Disponível em http://www.apublica.org/wpcontent/uploads/2013/03/Divulga\%C3\%A7\%C3\%A3o-dos-resultados_Apresenta\%C3\%A7\%C3\%A3o_Diagramada_Vers\%C3\%A3o-final.pdf, acesso em 06 de março de 2016.

FUNDAÇÃO PERSEU ABRAMO. Mulheres brasileiras e gênero nos espaços público e privado. Pesquisa de opinião pública. 2010. Disponível em http://www.apublica.org/wpcontent/uploads/2013/03/www.fpa_.org_.br_sites_default_files_pesquisaintegra.pdf, acesso em 17 de novembro de 2014.

GEERTZ, Clifford. Uma Descrição Densa: Por uma Teoria Interpretativa da Cultura. In A interpretação das Culturas. Rio de Janeiro: LTC, 1989. p. 3-21

GIBBS, Graham. Análise de Dados Qualitativos. Porto Alegre: Artmed, 2009.

GINZBURG, Carlo. O queijo e os vermes: o cotidiano e as idéias de um moleiro perseguido pela Inquisição. São Paulo: Companhia das Letras, 1998.

GONÇALVES, Aline de Oliveira. Da Internet às ruas: A Marcha do Parto em Casa. Dissertação de Mestrado apresentada ao Programa de Pós-Graduação da Universidade Federal do Paraná, 2014.

GRAMSCI, Antonio. Cuadernos de la cárcel. Volume 5. Puebla: Ediciones Era, 1999.

GROSFOGUEL, Ramón. A estrutura do conhecimento nas universidades ocidentalizadas: racismo/sexismo epistêmico e os quatro genocídios/epistemicídios do longo século XVI. In Soc. estado, Brasília , v. 31, n. 1, p. 25-49, Apr. 2016 . Disponível em 
http://www.scielo.br/scielo.php?script=sci_arttext\&pid=S0102-

$69922016000100025 \& \operatorname{lng}=$ en\&nrm=iso, acesso em 29 de julho de 2016.

GUERCI, Antonio; CONSIGLIERE, Stefania. Por uma Antropologia da Dor. Nota preliminar. Ilha Revista de Antropologia, Florianópolis, p. 57-72, jan. 1999. ISSN 2175-8034. Disponível em https://periodicos.ufsc.br/index.php/ilha/article/view/14444/13232, acesso em 04 de agosto de 2016.

HALL, Stuart. Antonio Gramscis Erneuerung des Marxismus und ihre Bedeutung für die Erforschung von "Rasse" und Ethnizität. In Ideologie, Kultur, Rassismus. Ausgewählte Schriften 1. Hamburg: Argument, 2000. p. 56-91

HALL, Stuart. Quem precisa de identidade. In SILVA, Tomaz Tadeu da (org.). Identidade e diferença: a perspectiva dos Estudos Culturais. Petrópolis: Vozes, 2000. p. 103-133

HALLIDAY, Michael Alexander Kirkwood. An introduction to functional grammar. 3. ed., revisada por C. Matthiessen. Oxford, Londres: Arnold, 2004.

HAMMERSCHMIDT, Claudia. 'Ich' ist ein Roman: Autofiktionalität bei Michel Houellebecq. In Mundus vetus - mundus novus. Festschrift für Johannes Kramer zum 65. Geburtstag, BECKER, Lidia; FELBECK, Christine; WILLEMS, Aline (orgs), München: Meidenbauer, 2011. p. 241-266.

HAMMERSLEY, Martyn. Ethnography and discourse analysis: incompatible or complementary? Polifonia (10) pp. 1-20, 2005.

HELMSTETTER, Rudolf. Popularisierungen. Wissen für Frauen zwischen “Fortplanzungszwecken und Schönheitsidealen”. In: LACHMANN, R., RIEGER, S. (orgs.), Text und Wissen: Technologische und anthropologische Aspekte. Tübingen: Narr, 2003, p. 181-195.

HOTIMSKY, Sonia Nussenzweig et al. Expectativas de Gestantes acerca do Parto e da Assistência Obstétrica. Cad. Saúde Pública, Rio de Janeiro, 18(5): 1303-1311, set-out, 2002. Disponível em http://www.scielo.br/scielo.php?script=sci_arttext\&pid=S0102311X2002000500023\&lng=en\&nrm=iso, acesso em 18 de maio 2014.

HOUAISS, Antônio; VILLAR, Mauro de Salles; FRANCO, Francisco Manoel de Mello. Dicionário Houaiss da língua portuguesa. Rio de Janeiro: Objetiva, 2009.

IUCN, 2016. Panthera leo. Disponível em http://www.iucnredlist.org/details/15951/0, acesso em $1^{\circ}$ de agosto de 2016. 
JÄGER Margarete. Fatale Effekte: Die Kritik am Patriarchat im Einwanderungsdiskurs, Duisburg: Diss, 1996.

JÄGER, Margarete; JÄGER, Sigfried. Deutungskämpfe: Theorie und Praxis Kritischer Diskursanalyse. Wiesbaden: VS Verlag, 2007.

JÄGER, Siegfried. Kritische Diskursanalyse: Eine Einführung, Münster: Unrast, 2012.

JÄGER, Siegfried. Kritische Diskursanalyse: Eine Einführung. Duisburg: DISS,1993.

JÄGER, Siegfried. Text- und Diskursanalyse: Eine Anleitung zur Analyse politischer Texte. Duisburg: DISS, 1987.

JONES, Ricardo Herbert. Atendimentos privados. In. Orelhas de vidro. 2016a. Disponível em https://orelhasdevidro.com/2016/10/20/atendimentos-privados/, acesso em 21 de outubro de 2016.

JONES, Ricardo Herbert. Periferias. In. Orelhas de vidro. 2016b. Disponível em https://orelhasdevidro.com/2016/10/20/atendimentos-privados/, acesso em 24 de outubro de 2016.

KELLER, Reiner et al (orgs). Handbuch Sozialwissenschaftliche Diskursanalyse. Band 1: Theorien und Methoden. Wiesbaden: VS Verlag für Sozialwissenschaften, 2011.

LAKOFF, George \& JOHNSON, Mark. Metáforas da vida cotidiana. Coordenação de tradução: Mara Sophia Zanotto. São Paulo: Mercado das Letras, 2002.

LAUER, Jeremy A. et al. Determinants of caesarean section rates in developed countries: supply, demandand opportunities for control. World Health Report, Background Paper, $29,2010$.

LEJEUNE, Phillipe. Le pacte autobiographique. Paris: Seuil, 1975.

MAGALHÃES, Izabel \& LEAL, Maria Christina Diniz. Discurso, Gênero e Educação. In MAGALHÃES, Izabel \& LEAL, Maria Christina Diniz (2003) (orgs.). Discurso, Gênero e Educação. Brasília: Editora Plano, 2003. p. 9-18

MAGALHÃES, Izabel. Eu e Tu: a constituição do sujeito no discurso médico. Brasília: Editora Thesaurus, 2000.

MAGALHÃES, Izabel. Interdiscursividade e Identidade de Gênero. In MAGALHÃES, Izabel \& LEAL, Maria Christina Diniz (orgs.). Discurso, Gênero e Educação. Brasília: Editora Plano, 2003. p. 33-62 
MAGALHAES, Izabel. Introdução: a análise de discurso crítica. DELTA, São Paulo, v. 21, n. spe, $\quad$ p. $\quad 1-9, \quad 2005 \quad$. $\quad$ Disponível em http://www.scielo.br/scielo.php?script=sci_arttext\&pid=S0102$44502005000300002 \& \operatorname{lng}=$ en\&nrm=iso, acesso em 19 de agosto de 2016.

MARTIN, James Robert \& WHITE, Peter Robert Rupert. The Language of Evaluation: appraisal in English. Hampshire \& New York: Palgrave Macmillan, 2005.

MARTINS, Alaerte Leandro. Mortalidade materna de mulheres negras no Brasil. Cad. Saúde Pública, 2006; 22(11):2473-2479

MASON, Jennifer. Qualitative researching. London: Sage, 2002.

MILROY, Lesley. Social Networks. In J. K. Chambers, J.K.; Trudgill, Peter \& Schilling-Estes, Natalie. The Handbook of Language Variation and Change. Oxford: Blackwell, 2008. p. 549-572.

MORAIS, Fátima Raquel Rosado. A humanização no parto e no nascimento: os saberes e as práticas no contexto de uma Maternidade pública brasileira. Tese de Doutorado, Programa de Pós-Graduação em Psicologia Social. Natal: Universidade Federal do Rio Grande do Norte, 2010.

MOTT, Maria Lúcia. Bibliografia Comentada sobre a assistência ao parto no Brasil. In Revista de Estudos Feministas, Jul 2002, vol.10, no.2, p.493-507.

MOTT, Maria Lúcia. Parto. In Revista de Estudos Feministas, Jul 2002, vol.10, no.2, p. 399401.

MOTT, Maria Lúcia.. Assistência ao parto: do domicílio ao hospital (1830 - 1960), Proj. História, São Paulo (25), dez., 2002 pp. 197-219.

MUNDLOS, Christina (2015). Gewalt unter der Geburt: der alltägliche Skandal. Marburg: Tectum Verlag.

NVivo 10 for Windows. Getting started guide. Portuguese. 2014. Disponível em http://download.qsrinternational.com/Document/NVivo10/NVivo10-Getting-StartedGuide-Portuguese.pdf, acesso em 28 de agosto de 2016.

OLIVEIRA, Bárbara Letícia R. de et al. O Enfermeiro como Educador: A Atuação do Enfermeiro no Contexto Hospitalar. In Revista de Pedagogia, ano 3, número 6, Notas de Pesquisa. Brasília: Universidade de Brasília, 2002. 
PACE, Ana Amélia Barros Coelho. Aspectos do pacto autobiográfico em “L'autobiographie en France". In Dorandina: Revista Eletrônica. Volume 6, nº 1, junho de 2013. Universidade Federal de Juiz de Fora. Disponível em http://www.ufjf.br/darandina/edicaoatual/volume-6-numero-1-junho2013/artigos/, acesso em 19 de setembro de 2016.

PARDO, Maria Laura. Teoría y metodología de la investigación lingüística. Método sincrónico-diacrónico de análisis lingüístico de textos. Buenos Aires: Tersites, 2011.

PATAH, Luciano Eduardo Maluf; MALIK, Ana Maria. 2011. Modelos de assistência ao parto e taxa de cesárea em diferentes países. Rev. Saúde Pública [online]. Vol.45, n.1, pp. 185194.

PEREIRA, Raquel da Rocha; FRANCO, Selma Cristina; BALDIN, Nelma. A dor e o protagonismo da mulher na parturição. Rev. Bras. Anestesiol., Campinas, v. 61, n. 3, p. 382-388, June 2011 . Disponível em http://www.scielo.br/scielo.php?script=sci_arttext\&pid=S0034$70942011000300014 \& \operatorname{lng}=e n \& n r m=$ iso, acesso em $1^{\circ}$ de agosto de 2016.

PÉREZ, Mercedes \& GÉRVAS, Juan. Encarnizamiento diagnóstico y terapéutico con las mujeres. Revista Semergen 25 (3), 1999. pp. 239-248.

POSSAMAI-INESEDY, Alphia. Who to trust? Giving birth in the risk society. In. TASA \& SAANZ 2007 Joint Conference Proceedings Public Sociologies: Lessons and TransTasman Comparisons, Auckland, New Zealand, 2008. Disponível em https://www.google.de/url?sa=t\&rct=j\&q=\&esrc=s\&source=web\&cd=2\&cad=rja\&uact =8\&ved=0ahUKEwj0oa-DgvjNAhWpI8AKHSfeB-

QQFggpMAE\&url=https\%3A\%2F\%2Fwww.tasa.org.au\%2Fwpcontent\%2Fuploads\%2F2008\%2F12\%2F56.pdf\&v6u=https\%3A\%2F\%2Fs-v6exp1ds.metric.gstatic.com\%2Fgen_204\%3Fip\%3D141.35.111.112\%26ts\%3D146867318041 5787\%26auth\%3Dri45rnb2sgawnczekhifof562mrromso\%26rndm\%3D0.540815111881 1209\&v6s=2\&v6t=21826\&usg=AFQjCNFVHOYrCMB8dSMUUwkjcGBrNcEpxA\&b vm=bv.127178174,d.ZGg, acesso em 16 de julho de 2016.

RAMALHO, Viviane \& RESENDE, Viviane de Melo. Análise de discurso (para a) crítica: $O$ texto como material de pesquisa. Campinas: Pontes Editores, 2011.

REGIS, Jacqueline Fiuza da Silva \& RESENDE, Viviane de Melo. "Daí você nasceu minha filha”: análise discursiva crítica de uma carta ao obstetra. DELTA vol.31 no.2 São Paulo July/Dec, 2015. 
REGIS, Jacqueline Fiuza da Silva. "Acho muito difícil você conseguir ter parto normal”: a violência obstétrica inscrita no discurso sobre o parto. In Livro de Atas do $1^{o}$ Congresso da Associação Internacional de Ciências Sociais e Humanas em Língua Portuguesa 2015, pp. 4728-4742

REGIS, Jacqueline Fiuza da Silva. Die Integrationskurse nach dem Gesetz zur Steuerung und Begrenzung der Zuwanderung und zur Regelung des Aufenthalts und der Integration von Unionsbürgern und Ausländern (Zuwanderungsgesetz) und ihre Auswirkung auf die Integrationserfahrungen Betroffener - Studie im empirischen Feld. Dissertação de Mestrado apresentada ao Instituto de Germanística Internacional da Universidade Friedrich Schiller, Jena, 2007.

REISIGL, Martin \& WODAK, Ruth. Discourse and Discrimination: Rhetorics of Racism and Antisemitism. Londres: Routledge, 2001.

RESENDE, Viviane de Melo. Análise de discurso crítica e etnografia: O movimento nacional de meninos e meninas de rua, sua crise e o protagonismo juvenil. Tese de doutorado. Programa de Pós-Graduação em Linguística, Universidade de Brasília, 2008.

RESENDE, Viviane de Melo. Análise de Discurso Crítica e Realismo Crítico: implicações interdisciplinares. Campinas: Pontes, 2009.

RESENDE, Viviane de Melo. Entre o legado europeu e a ousadia da crítica: análise de discurso crítica, contexto local e etnografia. In: SATO, Denise Tamaê Borges; BATISTA JÚNIOR, José Ribamar Lopes. (Org.). Contribuições da análise de discurso crítica no Brasil: uma homenagem a Izabel Magalhães. 1ed.Campinas: Pontes, 2013, p. 337-360

RESENDE, Viviane de Melo. Representação de pessoas em situação rua no jornalismo on-line: quais são as vozes convocadas para falar sobre a situação de rua? In. Revista de Estudos da Linguagem, UFMG, 2016, no prelo.

RESENDE, Viviane de Melo; RAMALHO, Viviane. Análise de Discurso Crítica. São Paulo: Contexto, 2006.

ROSA, Hartmut. Beschleunigung und Entfremdung - Entwurf einer kritischen Theorie spätmoderner Zeitlichkeit. Berlim: Suhrkamp, 2013.

SANTOS, Boaventura de Sousa. Para uma sociologia das ausências e uma sociologia das emergências. In: SANTOS, B.S. (Org.). Conhecimento prudente para uma vida decente: um discurso sobre ciências revisitado. São Paulo: Cortez, 2004. p.777-821. 
SANTOS, Boaventura de Sousa. Um Discurso sobre as Ciências. São Paulo: Cortez, 2006.

SANTOS, Silvéria Maria dos. Parteiras tradicionais da região do entorno do Distrito Federal. Tese (doutorado) - Universidade de Brasília, Instituto de Ciências Humanas, Departamento de História, 2010.

SAVE THE CHILDREN. Every last girl: Free to live, free to learn, free from harm. The Save the Children Fund: Inglaterra, 2016. Disponível em http://www.savethechildren.org/atf/cf/\%7B9def2ebe-10ae-432c-9bd0df91d2eba74a\%7D/EVERY\%20LAST\%20GIRL\%20REPORT\%20FINAL.PDF, acesso em 23 de outubro de 2016.

SEARLE, John R. Expression and meaning. Cambridge: University Press, 1999.

SHIRKY, Clay. A Cultura da Participação: Criatividade e Generosidade no Mundo Conectado. Rio de Janeiro: Zahar, 2011.

SILVA, Thais Santi Cardoso da. Do sujeito ao indivíduo que trabalha e consome: uma leitura da crise de legalidade a partir de Hannah Arendt. Dissertação de Mestrado, Universidade Federal de Santa Catarina, 2005.

SOUZA, Alex Sandro Rolland; AMORIM, Melania Maria Ramos; PORTO, Ana Maria Feitosa. Condições frequentemente associadas com cesariana, sem respaldo científico. In FEMINA, Setembro 2010, vol 38, $\mathrm{n}^{\circ} 10$.

TAKEMOTO, Maíra Libertad Soligo (2014). Caso Adelir - Era mesmo indicação absoluta de cesárea? Disponível em https://www.facebook.com/notes/ma\%C3\%ADra-soligotakemoto/caso-adelir-era-mesmo-indica\%C3\%A7\%C3\%A3o-absoluta-deces\%C3\%A1 rea/10202976004976377, acesso em 17 de julho de 2016.

TEW, Marjorie. Safer childbirth? A critical history of maternity care. London: Chapman \& Hall, 1990.

THOMPSON, Edward Palmer. „Mesa, você existe?”. In A miséria da Teoria, ou planetário de erros: uma crítica ao pensamento de Althusser. Rio de Janeiro: Zahar, 1981. p. 13-18

TORNQUIST, Carmen Susana. Armadilhas da Nova Era: Natureza e Maternidade no Ideário da Humanização do Parto. In Revista de Estudos Feministas, Jul 2002, vol.10, no.2, p.483-492. 
TORNQUIST, Carmen Susana. Parto e poder: o movimento pela humanização do parto no Brasil. 2004. Tese de Doutorado em Antropologia, Universidade Federal de Santa Catarina, Florianópolis, 2004.

UNICEF. Pesquisa para estimar a prevalência de nascimentos pré-termo no Brasil e explorar possíveis causas. $2013 . \quad$ Disponível em www.unicef.org/brazil/pt/br_prematuridade_possiveis_causas.pdf, acesso em $21 \mathrm{de}$ novembro de 2014.

VAN DIJK, Teun Adrianus. Communicating racism: ethnic prejudice in thought and talk. London: Sage, 1987.

VAN LEEUWEN, Theo. Discourse and Practice: New Tools for Critical Discourse Analysis. Oxford: University Press, 2008.

VENEZUELA. Ley orgánica sobre el derecho de las mujeres a una vida Libre de violencia. $2007 . \quad$ Disponível em http://www.mp.gob.ve/LEYES/LEY\%20ORGANICA\%20SOBRE\%20EL\%20DEREC HO\%20DE\%20LAS\%20MUJERES\%20A\%20UNA\%20VIDA\%20LIBRE\%20DE\%20 VIOLENCIA/LEY\%20ORGANICA\%20SOBRE\%20EL\%20DERECHO\%20DE\%20L AS\%20MUJERES\%20A\%20UNA\%20VIDA\%20LIBRE\%20DE\%20VIOLENCIA.htm 1, acesso em 23 de outubro de 2016.

Wikipedia. Leão. Disponível em https://pt.wikipedia.org/wiki/Le\%C3\%A3o, acesso $1^{\circ}$ de agosto de 2016.

WODAK, Ruth. Do que trata a ACD: Um resumo de sua história, conceitos importantes e seus desenvolvimentos. Linguagem em (Dis)curso, Tubarão, v. 4, n. esp, 2004. p. 223-243.

WODAK, Ruth; Meyer, Michael (orgs.). Methods of critical discourse studies. 3rd ed. London: Sage, 2015.

WYLLYS, Jean. Projeto de Lei 7633/2014, apresentado à Câmara dos Deputados, Brasil, 2014. Disponível em www.camara.gov.br/proposicoesWeb/fichadetramitacao?idProposicao=617546, acesso em 21 de novembro de 2014. 



\section{Anexos.}

Anexo 1 - nota com comentário de Elena sobre o filme Renascimento do Parto.

Impressões sobre o filme "O Renascimento do Parto"

Vou escrever este comentário porque fui "convidada" a fazê-lo. Tive muita vontade de assistir ao filme, mas não sai do cinema com grandes questões nem vontade de escrever ou discutir. Demorei muito para conseguir sentar para escrever estes comentários, o que me deu tempo para pensar um pouco mais sobre o filme, que tipo de sentimentos ele gerou em mim, oportunidade de conversar com outras pessoas mas também para esquecer algumas partes.

Eu gostei de assistir o filme, sai do cinema me sentido bem. Mas acho que tive esse sentimento pelo fato de ter tido sucesso no meu parto domiciliar. Talvez, se eu não tivesse passado por essa experiência, não tivesse nem coragem de assistir. E certamente sairia arrasada do cinema se assistisse. $\mathrm{O}$ filme tem vários méritos, trata de assuntos e assume posicionamentos que não são muito difundidos para o público em geral. Porém, ao mesmo tempo é muito taxativo e talvez chegue a "descriminar" quem não compartilhe das mesmas opiniões ou quem não teve acesso às informações e opiniões divulgadas.

Sempre que aparecia uma cena de cesárea me sentia muito mal, via a minha filha na pele daqueles bebes que estavam sofrendo nascendo daquele jeito. Me sentia muito culpada, assim como sempre me sinto quando vejo uma cesárea. Mas a cesárea foi mostrada apenas como o "bicho papão", como uma conduta terrível, não foi falado nada sobre as cesáreas necessárias, salvadoras. Me pareceu que o filme passa a mensagem de que o parto natural, humanizado, perfeito etc está disponível para qualquer uma, basta querer e correr atrás. E na minha opinião não é bem assim. Sei porque sofri isso na pele, porque precisa de dinheiro, de contatos, às vezes de sorte, de estar em um lugar onde haja profissionais certos disponíveis e acessíveis e, às vezes, como no meu caso, de uma história de vida que leve a procurar por tudo isso.

Outro ponto que me marcou e que ficou mais acentuado após conversas com outras pessoas que assistiram ao filme, foi a ideia de que existe só um caminho para o parto "certo". Que é apenas um certo tipo de profissional que faz isso da melhor forma possível, que existe uma receita certa, ou a melhor receita. 
Não tenho muito mais o que escrever, queria deixar claro que gostei do filme, é uma iniciativa incrível, presta um ótimo serviço, é bonito, entrevista pessoas muito boas, tenho muito mais elogios do que críticas. Sempre indico para as pessoas assistirem, meus pais inclusive, que foram assistir porque eu insisti, depois de o meu filho ter nascido em casa, entenderam bem melhor as coisas com o filme do que nas infindáveis conversas comigo e dos textos que eu mandei mas não sei se leram. (mas também, eu não sou nenhum Márcio Garcia, né?...)

Anexo 2 - Relato de parto de Lívia.

Meu relato de parto começa muito antes de parir: quando nos descobrimos grávidos, cada um sentiu um frio na barriga diferente. No caso do Marcos, me pareceu carregado de felicidade e realização. O meu veio acompanhado por um vendaval estomacal repleto de medo. Medo das mudanças, da responsabilidade, de não ter trabalhado o suficiente, de me doar, de não sentir o amor incondicional, de não saber cuidar, de não saber ser mãe, e claro!, o medo de passar por uma cirurgia. Não, meu medo nunca foi parir.

Começamos nosso pré-natal com a médica que cuida(va) de todas as mulheres da família, que me conhece desde os 11 anos de idade, aquela a quem eu confiava a minha vida. E seguimos com ela. Alguns medos eu deixei de sentir, outros permaneceram comigo. Confesso que essa médica não me animava muito. As consultas não eram lá muito calorosas, mas afinal o que eu queria... uma obstetra super requisitada ou uma amiga?

A essa altura, o Marcos já torcia o nariz a cada consulta e eu ainda me convencia: vamos lá minha gente, ela faz o que tem que ser feito, isso é o importante! Está cuidando de tudo! Por recomendação dela, vamos parar de fazer todo e qualquer exercício físico e vamos fazer as 12 ultrassonografias que ela sabe serem necessárias, para que o parto tenha chance de ser normal... Oi? Sim, essa foi a primeira vez que eu me questionei, mas ainda estava longe de mudar o rumo da nossa história.

Por volta das 24 semanas chegou a hora de fazermos nossa merecida viagem pra Europa, programada um ano antes e depois de dois anos sem férias. Mesmo informando a médica desde o começo do pré-natal, um dia antes de embarcarmos levamos bronca por nossa irresponsabilidade. "Viajar pra Europa? Ainda mais com essa crise, com o caos que está por lá?" Sim, fomos para a rota da crise: Grécia e Barcelona. “Olha minha filha, sua gestação não 
apresentou nenhum risco até agora, mas vocês quem sabem. Eu nunca perdi bebês aqui no Brasil, perdi apenas para viagens ao exterior, por doenças que não temos aqui, mas a decisão é de vocês". Isso me fez questionar: o problema não era a crise e o caos? Despejar toda essa culpa em nossas costas um dia antes? Com que propósito?

Discutimos muito sobre o assunto e decidimos seguir nossa intuição. Viajamos com o coração tranquilo, sem carregar nas malas nem culpa nem medo. Como era de se esperar, tudo correu sem problemas. Ah, foi uma viagem que só fez bem a nós três. Descansamos, comemos bem, sorrimos muito e pudemos refletir sobre o desejo de trazer nosso Gael ao mundo de forma mais natural.

Em uma conversa com uma amiga nossa, mãe dedicada e militante, ela disse uma frase que tocou meu coração, pois eu vi em seus olhos muito sentimento: "Quem me dera alguém tivesse me alertado em minha primeira gestação. Não teria sido submetida a uma cirurgia desnecessária”. Isso abriu meus olhos e minha cabeça para buscar o significado da humanização do parto.

O tempo foi passando, eu me sentia cada dia mais feliz e saudável. Passei a me questionar sobre como realmente seria nosso parto e resolvi entender da tal médica, sempre evasiva, afinal de contas, como é que seria o parto na visão dela. Resumindo, como ela mesma disse: "Se for normal será com todas as intervenções que tiver direito, 40 semanas é o limite e o tipo de parto só dá mesmo pra saber na hora H” Oi??? Fui!!!

Com 32 semanas e alguns amigos nos guiando, conhecemos a nossa obstetriz e aquele que viria a ser nosso médico parteiro. A sensação ao sair das consultas eu nunca vou esquecer... é difícil achar palavras pra descrever, mas foi como respirar novos ares. Pela primeira vez eu senti muito prazer em estar grávida.

Tudo fez sentido, pois minha vontade seria respeitada, afinal de contas, alguém estava me ouvindo. Não precisou muita conversa pra que eu entendesse o sentido da humanização, não só do parto, mas de todo o processo até chegarmos a ele. A obstetriz é uma fonte de energia e serenidade. O médico parteiro, um ser humano apaixonante. Ambos amam o que fazem e fazem com respeito.

Adiante com o pré-natal, agora respirando novos ares. Uma pergunta sobre o parto que o médico parteiro fez nas consultas foi: "Você tem medo de quê?" Eu ainda estava com alguns medos, 
verdade. Por vezes tentei responder essa pergunta a ele, e até inventei um medo: "Medo da pressão subir e eu passar mal no meio do parto", rs. Acho que ele não acreditou, mesmo assim com um punhado de palavras rebateu o "pseudo medo".

Não tenho medo da dor, nem da passagem do bebê, nem mais a placenta me põe medo. Entendi que do parto é que eu não tinha medo. Eu e o Marcos seguimos juntos o tempo todo, eu e eles, meus dois amores. Nossas consultas, as aulas de yoga da obstetriz para casais grávidos, os encontros na Casa Moara, o EPI-NO. Todo o processo foi fundamental para nos prepararmos para o desconhecido.

Com 38 semanas perdemos o tampão. Enviei um SMS para o médico parteiro e recebi como resposta: "Que lindo, mais um passo para seu parto maravilhoso". A obstetriz me disse: "Fique tranquila, pois ainda pode demorar um tempinho".

Resolvemos organizar o que faltava, pendurar os quadrinhos, fazer as malas da maternidade e o plano de parto. Uma das coisas mais importantes do plano de parto foi pedir: "Sorriam!! Não preciso saber com palavras se está tudo bem, se estiver, sorriam pra mim”.

Saí de casa pela manhã pensando "nossa hoje a barriga tá pegando, só falta entrar em trabalho de parto no meio da rua". Nesse dia resolvi antecipar um trabalho de compra dos móveis para a casa do meu primo, pois estava sentindo que deveria resolver todas as pendengas o quanto antes. Compramos tudo e fomos jantar. A essa altura sentia dificuldade de andar e um desconforto na parte de baixo da barriga. Fizemos o pedido para o garçom mais confuso da casa, que voltou cinco vezes pra confirmar o que queríamos. Foi a sorte, pois tivemos tempo de cancelar os pratos. Com 38 semanas e seis dias a hora havia chegado!

Lembro de ter olhado o relógio: 22h. Depois de sentir um calafrio e uma pressão, sem dor, eu senti um misto de curiosidade e felicidade. O tempo parou, olhei a minha volta e disse com um sorriso largo no rosto: "Garçom, cancela o pedido, pois minha bolsa rompeu". Meu primo e a esposa dele ficaram em pânico, umas senhoras que estavam no restaurante me olhavam sorrindo e dizendo "Bom parto minha filha".

Achei graça a bolsa ter rompido. A sensação do líquido escorrendo pelas pernas foi carregada de felicidade e realização. Não tive medo. Sorri em resposta às senhoras e acalmei meus primos. Pedi que me levassem para casa e não para o hospital como eles sugeriram. 
A caminho de casa as contrações começaram... não achei graça nisso. Liguei para o Marcos e quando cheguei em casa tive uma sensação de alívio (não nas dores) emocional. Vi que ele preparou a casa pra mim: baixou as luzes e colocou as músicas que escolhemos para o parto. Sentir que ele estava lá, presente em todos os sentidos, foi a maior segurança que eu podia ter.

No chuveiro, as massagens na lombar fizeram sucesso. As contrações foram aumentando e ele achou que era hora de marcar o tempo de cada uma. Combinamos de ligar para a obstetriz quando marcássemos 14 contrações por hora. O Marcos se assustou com a primeira marcação, pois marcamos 21 na primeira hora!

A obstetriz resolveu nos encontrar em casa, pois era muita contração para a primeira hora de trabalho de parto. Chegou em casa meia noite e avaliou que, apesar de estar bem ritmada, a dilatação estava em dois centímetros apenas. Por orientação dela fomos para o quarto descansar e preservar energia.

Confesso que saber que ela estava do nosso lado, logo ali na sala, me deu mais segurança. Parei de racionalizar quando ouvi dela: “Que bom, mais uma contração significa uma a menos pra você conhecer o Gael”. Resolvi me entregar à dor, sem tentar aliviar ou evitar que aumentasse. Respira Camila, respira!

Achei uma posição confortável, sentada com as mãos na lateral do corpo apoiada na cama. Dormi entre uma contração e outra. O tempo passou e eu não vi.

Às quatro da manhã estava com cinco centímetros e resolvi pedir que me levassem para o hospital. Não queria passar pelo que uma amiga passou, na fase ativa presa no trânsito. Chegamos ao hospital.

Meu cunhado nos ajudou com a internação (combinamos com ele meses antes, pois ele queria ajudar de alguma forma) o que foi fundamental, já que assim, a obstetriz e o Marcos puderam ficar comigo o tempo todo. Nem por um instante eu fiquei sozinha.

Nessa fase minhas lembranças são vagas. Sei que não demorou para entrarmos na suíte de parto. As contrações estavam bem ritmadas e a dilatação caminhando bem, já estava com seis centímetros a essa altura. Sentei na bola pra me movimentar, pelo amor!!! Queria explodir a maldita bola! A única posição que conseguia ficar era sentada em uma poltrona com as mãos apoiadas na lateral. 
Com as contrações aumentando de intensidade e ritmo, entrar na banheira parecia ser minha única salvação, e foi pra lá que eu fui!

Tudo corria de acordo com nosso plano de parto e, de acordo com minha vontade, o expulsivo caminhava para ser na água mesmo. Todo o tempo que fiquei na água, me senti entregue para a fase mais intensa do trabalho de parto. As contrações chegaram ao pico e foi a única vez que me lembro de querer saber que raios estava acontecendo. Perguntei à obstetriz "Que dor era aquela? Isso vai aumentar?" Para minha alegria, ela iria se manter, aumentar não, e na fase expulsiva, ao fazer força, vai passar... ah, o paraíso!

Sempre imaginei como seria a tal vontade de fazer força. Seria psicológica? Racional? Ou física? Física! Senti o corpo se contrair por vontade própria, como um espasmo, um movimento involuntário.

Eu que fui pra longe, esvaziei a mente durante toda fase ativa, voltei! Finquei os pés no chão! Lembrei das conversas do pré-natal, no foco que eu precisaria ter nessa fase. Mas, quando fiz força ao sentir a tal vontade física... dor... foi só o que eu senti... seguida de uma vontade enorme de perguntar sobre o fórceps e anestesia! Não verbalizei. Sabia que falar seria pra mim uma entrega que eu não queria. Respirei e disse para a obstetriz que a dor não havia passado ao fazer força. A médica parteira então chegou e avaliou que ainda faltava um rebordo do colo para dilatar, mesmo estando no expulsivo. Que uma simples manobra faria o colo abrir e a dor passaria... será?

O médico parteiro chegou, sentou, olhou, apoiou suas mãos sobre as minhas e sorriu. Nesse momento eu percebi para que esse homem veio ao mundo... para estar lá! Para sentar ao nosso lado, olhar com carinho e atenção, nos dar apoio e segurança com suas mãos gigantes e para sorrir com o coração!

Ele sugeriu que, depois de duas horas na banheira, nós pudéssemos estimular o processo caminhando um pouco. Àquela altura eu aceitaria toda e qualquer sugestão! Pedi a tal manobra que a médica parteira havia sugerido e, por isso, fui para uma maca.

Uma contração e uma manobra para abrir o colo do útero seguida por um alívio imenso. Esses foram os melhores momentos do meu trabalho de parto. Nesse instante, a dor passou e a entrega foi total. Eu só queria respirar fundo e fazer força! 
Mais uma vez o médico parteiro sugeriu uma posição diferente, dessa vez a banqueta de parto, claro que eu fui logo aceitando. Essa foi simplesmente a melhor posição que podia existir no mundo para eu parir! Incrível!

Senti um controle sem igual sobre meu corpo, pude sentir onde o bebê estava, pude controlar a intensidade das forças que eu fazia, pude agarrar o pescoço do Marcos e puxar com toda força a cada contração (ele estava sentado atrás de mim apoiando minhas costas). Foi mágico!

A obstetriz logo anunciou que o Gael estava com dois dedos da cabecinha pra fora e que estava chegando. Fui tomada por uma alegria imensa, resolvi que ele iria nascer naquele momento. Fiz força, senti o círculo de fogo (bem melhor que o EPI-NO), mais uma força e ele veio me olhar... nasceu de olhos abertos e gritou bem alto.

Senti uma alegria tão intensa, fiquei paralisada sorrindo e olhando pra ele. A placenta que ainda me dava um medinho... que placenta?? Ela nasceu e eu nem vi.

Com ele no colo, voltei para a maca e por ali ficamos por muito tempo. Eu olhando pra ele, ele dormindo e o Marcos chorando. Foi um momento em que o tempo parou.

Hoje o Gael está com um mês, lindo e saudável. Olho para trás e respiro aliviada todos os dias quando penso que sempre é tempo de mudar. Que basta ter coragem para conhecer o novo e mudar o ponto de vista. Que ter desconfiado de tantas certezas me fez renascer como mulher.

Ter parido da forma que eu queria fez de mim uma mulher realizada! 



\section{Declaração de Honra}

Eu, Jacqueline Fiuza da Silva Regis, ao solicitar a abertura de processo de defesa de tese de doutorado junto ao Programa de Pós-Graduação em Linguística da Universidade de Brasília, declaro que:

(a) conheço o Regulamento do Programa de Pós-Graduação em Linguística da Universidade de Brasília, bem como as normativas dessa universidade que regulamentam o processo de doutoramento,

(b) eu mesma redigi a tese de doutorado a ser avaliada, sem copiar textos de outros autores ou textos próprios usados em outros trabalhos avaliados para obtenção de títulos acadêmicos sem que isso esteja claramente indicado na tese, assim como estão indicadas todas as fontes e outros materiais utilizados,

(c) não recorri a nenhuma consultoria paga para a elaboração desta tese, não havendo terceiros que tenham recebido nenhum tipo de benefício monetário direto ou indireto para a realização de nenhuma parte do conteúdo da tese apresentada,

(e) eu apresentarei a mesma tese na abertura do processo de doutoramento na Friedrich-SchillerUniversität Jena, conforme o Convênio de Cotutela de Tese de Doutorado, sob o qual realizei meu doutoramento

Brasília e Jena, 19 de dezembro de 2016.

Jacqueline Fiuza da Silva Regis 



\section{Ehrenwörtliche Erklärung}

Hiermit erkläre ich, Jacqueline Fiuza da Silva Regis, als Antragsteller der Eröffnung eines Promotionsverfahrens an der Philosophischen Fakultät der Friedrich Schiller-Universität Jena,

(a) dass mir die geltende Promotionsordnung bekannt ist,

(b) dass ich die Dissertation Violência e resistência: representação discursiva da assistência obstétrica no Brasil em relatos de parto e cartas à/ao obstetra selbst angefertigt, keine Textabschnitte eines anderen Autors oder eigener Prüfungsarbeiten ohne Kennzeichnung übernommen und alle von mir benutzten Hilfsmittel und Quellen in meiner Arbeit angegeben habe,

(c) dass die Hilfe eines Promotionsberaters nicht in Anspruch genommen wurde und dass Dritte weder unmittelbar noch mittelbar geldwerte Leistungen vom Promovenden für Arbeiten erhalten haben, die im Zusammenhang mit dem Inhalt der vorgelegten Dissertation stehen,

(d) dass ich die Dissertation noch nicht als Prüfungsarbeit für eine wissenschaftliche Prüfung eingereicht hat, außer für die Verteidigung der gleichen Dissertation an der Universidade de Brasília, gemäß dem Kooperationsvertrag für ein binationales Promotionsverfahren, unter dessen ich promoviert habe.

(e) dass ich, gemäß dem Kooperationsvertrag für das binationale Promotionsverfahren, in dessen Rahmen ich die Dissertation verfasst habe, die gleiche Dissertation bei der Universidade de Brasília eingereicht habe. Das Ergebnis an der Universidade de Brasília war „aprovado“ (bestanden). Gemäß der Promotionsordnung der Universidade de Brasília (Resolução CEPE 91/2004) wird das Promotionsverfahren nicht benotet, die möglichen Ergebnisse sind „aprovação" (,,bestanden“), „,aprovação com revisão de forma“ („,,bestanden mit Revision der Form); reformulação“ („Neuformulierung“) oder „reprovação“ („nicht bestanden“").

Jena und Brasilia, den 19. Dezember 2016. 



\section{Persönliche Daten}

Name Jacqueline Fiuza da Silva Regis

Geburtsdatum/-ort 21/03/1976 - Brasília/DF - Brasil

Reisepass $\quad$ FI 883406

CPF 775.935.961-68

Anschrift SQN 104, Bloco E, Apto 306. Brasília-DF, Brasilien 70733-050

E-Mail-Adresse _ jacqueline.fiuza@uni-jena.de

fiuzaregis@yahoo.de

\section{Schulischer Werdegang}

1992 - 1994 Ensino de $2^{\circ} \mathrm{Grau}$

am Centro Educacional Setor Leste, Brasilia, Brasilien

1982 - $1989 \quad$ Ensino de $1^{\circ} \mathrm{Grau}$

an der Escola Classe nº 9, Brasilia, Brasilien, 1982-1985

am Centro de Ensino n ${ }^{\circ}$ 11, Brasilia, Brasilien, 1986-1987

am Centro Educacional JK, Brasilia, Brasilien, 1988-1989

\section{Akademischer Werdegang}

2012 - 2016 Promotion im Cotutelleverfahren .

an der Universidade de Brasília, Brasilia, Brasilien 
und an der Friedrich-Schiller-Universität Jena, Deutschland

Dissertationstitel:

„Violência e resistência: representação discursiva da assistência obstétrica no Brasil em relatos de parto e cartas à/ao obstetra"

\section{Betreuung:}

Prof. Dr. Viviane de Melo Resende

Prof. Dr. Claudia Hammerschmidt

\section{Stipendien:}

Coordenação de Aperfeiçoamento de Pessoal de Nível Superior (CAPES)

Deutscher Akademischer Austauschdienst

2004 - 2007 Magisterstudium der Auslandsgermanistik DaF/ DaZ, Romanistik und Politikwissenschaft an der Friedrich- Schiller-Universität Jena, Abschluss Oktober 2007

2003 - 2004 Austauschstudentin in den Fächern Romanistik (Portugiesisch) und Deutsch als Fremdsprache an der Friedrich-Schiller-Universität, Jena, Oktober 2003 bis September 2004

2002 - 2003 Forschungsstudentin des CNPq (Conselho Nacional de Desenvolvimento Científico e Tecnológico), im Forschungsprojekt „Geschichte der portugiesischen Sprache“ 2002 - 2003

2002 - 2003 Studium der Romanistik (Portugiesisch) und Deutsch als Fremdsprache an der Universidade Federal da Bahia (UFBA), Brasilien, 2002-2003

2000

Fortbildung in Politikwissenschaft, Universidade Internacional de Andaluzia, Huelva. Spanien, April bis Juli 2000

1993 - 1999 Bakkalaureus in Politikwissenschaft, Universidade de Brasília (UnB), 1993 1999

\section{Beruflicher Werdegang}

Sprachlehrerin für Deutsch als Fremdsprache und Portugiesisch an der Escola Waldorf Moara - seit 2015

Dozentin für Deutsch als Fremdsprache am der Goethe-Zentrum Brasília - von August 2008 bis Dezember 2012

Dozentin für Deutsch als Fremdsprache an der Universidade de Brasília - von April 2009 bis April 2011 
Dozentin für Deutsch als Fremdsprache für Hörer aller Fakultäten an der Universidade Federal da Bahia - Projeto de Extensão - von Februar 2008 bis Juli 2008

Dozentin für Kulturstudien/Brasilien am Institut für Romanistik an der Philosophischen Fakultät der Friedrich-Schiller-Universität, Jena, vom April 2005 bis September 2007

Lehrerin für brasilianisches Portugiesisch und Deutsch als Fremdsprache am Sprachenzentrum der Friedrich-Schiller-Universität, vom Oktober 2004 bis September 2007

Kursleiterin für brasilianisches Portugiesisch an der Volkshochschule Jena, vom April 2005 bis September 2006

Leitung eines Sprachvorbereitungskurses für Portugiesisch im Rahmen des EUProgramms Leonardo am Staatlichen Berufsbildenden Schulzentrum Jena-Göschwitz, im März 2005

Studentische Hilfskraft bei Prof. Dr. Hans Barkowski am Institut für Auslandsgermanistik Deutsch als Fremd- und Zweitsprache, vom Juni 2005 bis Dezember 2007

Praktikum am Sprachenzentrum der Friedrich-Schiller-Universität, im Projekt Deutsch in Stationen Lernen, unter Leitung der Dr. Susanne Hecht, im Sommersemester 2005

Studentische Sprachtutorin am Institut für Romanistik der Friedrich-Schiller-Universität, vom Oktober 2003 bis September 2004

Dozentin für Deutsch als Fremdsprache für Hörer aller Fakultäten an der Universidade Federal da Bahia - Projeto de Extensão - vom Januar 2002 bis September 2003

Tandem-Englischlehrerin im sozialen Tanzprojekt Grupo Afrobahia, Salvador, Bahia, 2002

Deutsch- und Englischlehrerin bei Yázigi Internexus, Brasília, 2000

Ehrenamtliche Mitarbeit in der Abteilung für Ausländische Beziehungen, bei MISSÃO CRIANÇA, Nicht-Regierungs-Organisation für die Erziehung armer Kindern, Brasília, 1999

Praktikantin am Ministério da Educação e do Desporto (Erziehungsministerium), Abteilung für Universitäre Ausländische Beziehungen und Erstellung der CELPE-Bras (Offizielle Sprachprüfung für Brasilianisches Portugiesich) Brasília, 1997-1998

Freiberufliche Sprachlehrerin für Deutsch und brasilianisches Portugiesisch seit 1997

Sprachkenntnisse

Portugiesisch: $\quad$ Muttersprache

Deutsch: $\quad$ Sehr gute Kenntnisse

Englisch: $\quad$ Oberstufenkenntnisse

Spanisch: Oberstufenkenntnisse 
Französisch: Oberstufenkenntnisse

\section{Preise}

2007

Gewinner des Hochschulwettbewerbs "Geist begeistert" zum Jahr der Geisteswissenschaften 2007, Bundesministerium für Bildung und Forschung (BMBF)

2005

Preis des Deutschen Akademischen Austauschdientes (DAAD) für hervorragende Leistungen ausländischer Studierende, FSU - FriedrichSchiller-Universität Jena

\section{Veröffentlichungen}

REGIS, Jacqueline Fiuza da Silva \& RESENDE, Viviane de Melo. "Daí você nasceu minha filha": análise discursiva crítica de uma carta ao obstetra. DELTA vol.31 no.2 São Paulo July/Dec, 2015.

REGIS, Jacqueline Fiuza da Silva. "Acho muito difícil você conseguir ter parto normal": a violência obstétrica inscrita no discurso sobre o parto. In Livro de Atas do $1^{\circ}$ Congresso da Associação Internacional de Ciências Sociais e Humanas em Língua Portuguesa 2015, pp. $4728-4742$

REGIS, Jacqueline Fiuza da Silva (2013). O WordSmith Tools como ferramenta para Análise de Discurso Crítica: exercício analítico com relatos de partos In: II Semana de Reflexões sobre Negritude, Gênero e Raça, 2013, Brasília. SERNEGRA: II Semana de Reflexões sobre Negritude, Gênero e Raça. Brasília: Editora do IFB, 2013.

REGIS, Jacqueline Fiuza da Silva (2011). The visual representation of birth: an incursion in the multimodal critical discourse analysis proposed by Theo van Leeuwen \& Gunther Kress In: 38th International Systemic Functional Congress, 2011, Lisboa. ISFC38 Book of Abstracts, 2011.

REGIS, Jacqueline Fiuza da Silva. Die Integrationskurse nach dem Gesetz zur Steuerung und Begrenzung der Zuwanderung und zur Regelung des Aufenthalts und der Integration von Unionsbürgern und Ausländern (Zuwanderungsgesetz) und ihre Auswirkung auf die Integrationserfahrungen Betroffener - Studie im empirischen Feld. Dissertação de Mestrado apresentada ao Instituto de Germanística Internacional da Universidade Friedrich Schiller, Jena, 2007.

REGIS, Jacqueline Fiuza da Silva (2010). idealer Sprecher-Hörer; Kopula; Kopulasatz; . Lemma; Monosemie; Morph; Morphem; Morphologie. In. Barkowski, Hans / Krumm, HansJürgen (Hrgs.). Fachlexikon Deutsch als Fremd- und Zweitsprache. Tübingen; Basel: A. Francke UTB.

FEIJÓ, Glauco Vaz \& REGIS, Jacqueline Fiuza da Silva (Orgs.) (2007). Festival de Colores: Dialoge über die portugiesischsprachige Welt. Tuebingen: Calepinus. $432 \mathrm{~S}$. 
REGIS, Jacqueline Fiuza da Silva (2007). Lengua e integración en Alemania: ¿Cuánto Nominativ, Dativ o Akkusativ (no) es necesario? In: Interculturalidad y Lenguaje 2. Identidad cultural y pluralidad lingüística. Granada: Método Ediciones. S. 129 - 138

REGIS, Jacqueline Fiuza da Silva (2007). Die Debatte über die ações afirmativas in Brasilien und die Quotenpolitik in Salvador da Bahia. In: Born, Joachim. Curt Unckel Nimuendajú - ein Jenenser als Pionier im brasilianischen Nord(ost)en. Wien: Praesens. S. 287 - 301

REGIS, Jacqueline Fiuza da Silva (2006). Körpersprache im Interkulturellen Vergleich und in der Unterrichtspraxis. In: Sammelband der Karelischen Pädagogischen Universität. Petrosawodsk: http://www.lingvomaster.ru/files/61.pdf. S. $354-360$

REGIS, Jacqueline Fiuza da Silva (2003). Posse e Discurso: o que um possessivo quer dizer. In: Language Design: Journal of Theoretical and Experimental Linguistics. Granada: Método Ediciones. S. $11-18$

REGIS, Jacqueline Fiuza da Silva (2003). Posse e estratégia de relativização: a posse que não é posse. Veröffentlicht bei der 55ª Reunião Anual da SBPC, Juli 2003.

MEDEIROS, Carmen Lúcia; SANTOS, Grabriela C. dos; REGIS, Jacqueline Fiuza da S (2002). Salvar ou Deletar? In: VI Congresso Nacional de Estudos Linguiísticos e Literários: Livro de Resumos. Feira de Santana: UEFS.

\section{Vorträge und Fachkonferenzen (Auswahl)}

REGIS, Jacqueline Fiuza da Silva. A ADC e as contribuições da Escola de Duisburg, 2016.

REGIS, Jacqueline Fiuza da Silva. The Risk of Giving Birth in Brazil: The Struggle for Obstetric and Post-Partum Care without Violence, 2016.

REGIS, Jacqueline Fiuza da Silva. "Acho muito difícil você conseguir ter parto normal": a violência obstétrica inscrita no discurso sobre o parto, 2015.

REGIS, Jacqueline Fiuza da Silva. 'Da haben Sie meine Tochter geboren':_ Kritische Diskursanalyse eines Briefes _an die ärztliche Geburtshilfe, 2014.

REGIS, Jacqueline Fiuza da Silva. "Der wahre Schmerz ist die Gewalt": Schwangerschaft und Geburt in Brasilien, 2014.

REGIS, Jacqueline Fiuza da Silva. “'Então, pra quando você quer marcar a sua cirurgia?': sobre a representação discursiva da relação obstetra/parturiente no relato de parto”, 2012.

REGIS, Jacqueline Fiuza da Silva. O ensino de línguas estrangeiras na formação do tradutor: novas perspectivas?, 2010.

REGIS, Jacqueline Fiuza da Silva. Sambando para aprender alemão - língua e integração na Alemanha, 2010.

REGIS, Jacqueline Fiuza da Silva. Lengua, migración e integración en Alemania: Los 
Integrationskurse, 2007.

REGIS, Jacqueline Fiuza da Silva. Más allá de las palabras: Aspectos paraverbales y no verbales en la comunicación oral, 2007.

REGIS, Jacqueline Fiuza da Silva. Nach dem Integrationskurs - eine empirische Untersuchung am Beispiel brasilianischer TeilnehmerInnen, 2007.

HECHT, Susanne, REGIS, Jacqueline Fiuza da Silva. Was ist los in Hauptstraße 177 Vorstellung eines Online-Selbstlernkurses, 2007.

REGIS, Jacqueline Fiuza da Silva. Lengua e integración en Alemania ¿Cuánto Nominativ, Dativ o Akkusativ (no) es necesario?, 2006.

REGIS, Jacqueline Fiuza da Silva. Die Debatte über die ações afirmativas in Brasilien und die Quotenpolitik in Salvador da Bahia, 2005.

REGIS, Jacqueline Fiuza da Silva. Körpersprache im Interkulturellen Vergleich und in der Unterrichtspraxis, 2005.

\section{Andere Angaben}

Mitglied im Núcleo de Estudos de Linguagem e Sociedade (NELiS) des Centro de Estudos Avançados Multidisciplinares (CEAM) der Universidade de Brasília (UnB) seit 2010.

Teilnahme am Extensionsprogramm der Universidade de Brasília in der Studiengruppe Discurso e Prática: ciclo de estudos em Análise de Discurso. 1. Semester 2010

2. koordinierende Sektionsleiterin zur Sektion "Deutsch als Zweitsprache im Kontext von Migration und Integration" der VIX. Internationalen Deutschlehrer Tagung Jena-Weimar 2009

Projektleitung des Festivals de Colores - Portugiesisch in aller Welt. Preisträger des Hochschulwettbewerbs Geist begeistert zum Jahr der Geisteswissenschaften 2007, Bundesministerium für Bildung und Forschung

Mitwirkung als Protagonistin des Imagefilms der Friedrich-Schiller-Universität Lichtstadt Univercity Jena Stadt der Wissenschaft, einer Produktion der MCS Thüringen, 2007

DAAD-Preisträgerin für hervorragende Leistungen ausländischer Studierender, 2005

Leitung des Sprachlernprojekts Meu mundo em português (Meine Welt auf Portugiesisch) einer medienpädagogischen Arbeit des Sprachenzentrums im Offenen Kanal Jena, Wintersemester 2005

Zweisprachige Moderation der Sendung Rádio Brasileira, im Offenen Kanal Jena, 2005

Veranstaltung des Filmvorführungsprogramms Cine Brasil am Multimediazentrum der Friedrich-Schiller-Universität, Oktober 2004 bis September 2006 
Organisation des wöchentlichen Stammtisches Portugiesisch in Jena, Oktober 2003 bis September 2004

Au-pair-Aufenthalt, bei Familie Grub-Simon, Stuttgart, April1995 bis März 1996

Jena und Brasilia, den 19. Dezember 2016.

Jacqueline Fiuza da Silva Regis 



\section{Extendierte Zusammenfassung (auf Deutsch)}

Im Rahmen meines Promotionsvorhabens, das ich mit der Dissertation „Gewalt und Widerstand: Diskursive Repräsentation der Geburtshilfe in Brasilien anhand von Geburtsberichten und Briefen an die Geburtshilfe" abschließe, werden Geburtsberichte und Briefe analysiert, in denen Frauen ihre Erfahrungen mit Schwangerschaft, Geburt und Geburtshilfe beschreiben und dabei oftmals die Gewalt, die ihnen während dieser Ereignisse widerfahren ist, beklagen. Unter anderem aus diesen Erfahrungen heraus formieren sie sich zu Subjekten des Widerstandes gegen diese Gewalt sowie des Kampfes für ihre sexuellen und reproduktiven Rechte.

In den untersuchten Dokumenten kommt der Aspekt der Gewalt unter der Geburt immer wieder direkt oder indirekt zur Sprache. Diese spezifische Form der Gewalt, die in Brasilien noch einer gesetzlichen Definition entbehrt, wird hier verstanden im Sinne des ersten, 2007 in Venezuela erlassenen Gesetzes in Lateinamerika, das die „Gewalt unter der Geburt“ beschreibt und anerkennt: Danach entspricht die Gewalt unter der Geburt

(...) der Inbesitznahme des weiblichen Körpers sowie seiner reproduktiven Vorgänge durch medizinisches Personal, eine Inbesitznahme, die sich durch eine inhumane Behandlung der betroffenen Frauen, durch den inadäquaten Einsatz von Medikamenten und durch die Pathologisierung natürlicher Prozesse auszeichnet und damit zum Verlust der Autonomie sowie der Möglichkeit der Frauen führt, frei über ihren Körper sowie ihre Sexualität zu entscheiden, und somit eine Verschlechterung der Lebensqualität der Frauen nach sich zieht. (Venezuela, 2007)

Wo Gewalt herrscht, herrscht auch Widerstand: Frauen setzen sich in horizontalen Netzwerken der Solidarität für Emanzpation und Frauenrechte insbesondere im Bereich der Menschenrechte, sexuellen sowie reproduktiven Rechte ein. Diese Netze des Widerstandes können als identitätssiftendes kollektives Projekt verstanden werden, das auf eine Verschiebung hegemonialer Verhältnisse im Sinne Gramscis sowie auf die Schaffung eines subjektiven Raumes für die Frauen abzielt, in dem es ihnen möglich ist, sich ohne Angst vor frauengerichteter Gewalt zu bewegen, in dem sie frei über Eingriffe an ihrem Körper entscheiden können, in dem Menschenrechte sowie sexuelle und reproduktive Rechte gesetzlich zugesichert sind, darunter insbesondere das Recht auf eine würdige, respektvolle, ethische, professionelle und humane (bzw. humanisierte) Geburtshilfe. 
In diesem Zusammenhang vermögen verschiedene individuelle wie kollektive Vorhaben, den „Fluss des Wissens durch Raum und Zeit“, den Diskurs über die Geburt, umzulenken. Die Redaktion und Verbreitung von Geburtsberichten und Briefen an die Geburtshilfe sind beispielhaft für diese Vorhaben, bei denen Frauen die ihnen vorhandenen Ressourcen nutzen, um ihre Erfahrungen zu kommunizieren, oft in Form eines Manifests, eines Aufrufs zum Widerstand gegen die Gewalt, aber auch als Versprechen einer würdigeren Pflege. Dies hat mich zu der Entscheidung bewogen, diese Art Dokumente zu analysieren.

Die Studie, interdisziplinär allein schon aufgrund der Vielschichtigkeit des behandelten Themas, bedient sich analytisch der Mittel der Kritischen Diskursanalyse (KDA) (M. Jäger, 1996; Chouliaraki \& Fairclough, 1999; Fairclough, 2003; Resende, 2009; Ramalho \& Resende, 2011; S. Jäger, 2012) und setzt den Schwerpunkt auf die Untersuchung der Repräsentation, Identifikation und Aktion von Frauen innerhalb des Diskursstranges, der Schwangerschaft, Geburt und damit auch Geburtshilfe umfasst. Forschungsvorhaben, die dem Ansatz der Kritischen Diskursanalyse folgen, gehen zwangsläufig von einem sozialen Beweggrund aus, verzichten auf wissenschaftliche Neutralität und manifestieren eingangs offen und transparent ihr politisches Engagement sowie das Interesse, durch ihre Forschungsleistung zu einer Linderung des behandelten sozialen Problems beizutragen.

In Kapitel 1 führe ich in die gegenwärtige Situation der Geburtshilfe in Brasilien ein, zeige Aspekte auf, die mit dort institutionalisierter Gewalt unter der Geburt in Zusammenhang stehen (Aguiar, 2010; Diniz \& Chacham, 2006; Diniz, 2009, Pereira, Franco e Baldin, 2011) und stelle die Bewegung der Frauen vor, die im emanzipatorischen Kampf für ihre sexuellen und reproduktiven Rechte Widerstand gegen diese Form der Gewalt leisten. Diese Kontextualisierung ist u.a. notwendig, um den zu behandelnden diskursiven Strang, d.h. den thematischen Schnitt im Diskurs, der Angelegenheit der Studie ist, klar einzugrenzen. Kapitel 2 behandelt diesen sowie weitere der Dissertation zu Grunde liegende Forschungsansätze und -begriffe.

Darüber hinaus beleuchte ich in Kapitel 2 Aspekte meiner Biographie, die Einfluss auf mein Vorgehen genommen haben, sowie die angewandten Konzepte und analytischen Kategorien. Daraufhin erläutere ich mein Verständnis von den ontologischen Gesichtspunkten der sozialen Welt und stütze mich dabei auf Resende (2009), die dabei hilft, Brücken insbesondere zwischen der Kritischen Diskursanalyse der britischen Schule (Chouliaraki e Fairclough, 1999; Fairclough, 2003) sowie des Kritischen Realismus (Bhaskar, 1989) zu bauen. An dieser Stelle erkläre und rechtfertige ich ferner, weshalb ich diese Ansätze mit der KDA der Duisburger 
Schule (M. Jäger, 1996; S. Jäger, 2012) kombiniert und mich bei der Organisation meiner Dissertation methodologisch darangehalten habe.

Abschließend erschließe ich in Kapitel 2 die Materialbasis sowie den Korpus vorliegender Arbeit und führe erstmals an die Frauen heran, die mit ihren Berichten und Briefen zu diesem Vorhaben beigetragen haben.

Ein erster analytischer Schritt, die Makro- bzw. Strukturanalyse (M. Jäger, 1996), erfolgt in Kapitel 3. Die Themen werden zunächst nur im Ansatz vorgestellt, die linguistische Auswertung geht nicht in die Tiefe. Kommentiert werden die am häufigsten in den Berichten und Briefen auftretenden Einzelthemen des $\mathrm{zu}$ untersuchenden Diskursstranges: Selbstidentifikation, mystische und spirituelle Fragestellungen, das Bedürfnis nach Begleitung unter der Geburt, Schmerz und Angst und ihre pluralistische Konzeption, Neuausrichtung des Körpers und seiner Bedürfnisse unter der Geburt, die Aufforderung zum Widerstand, u.a..

In den Kapiteln 4 und 5 folgen die exemplarischen Feinanalysen, in denen gemäß M. Jäger (1996) als Beispiel dienende Texte nach Festlegung des Diskursstranges sowie struktureller Grobanalyse auch anhand linguistischer und textueller Strategien tiefgehend untersucht und ausgewertet werden. Für Kapitel 4 wurden als Korpus zwei Geburtsberichte ausgewählt, für Kapitel 5 zwei Briefe an die Geburtshilfe.

Im Anschluss an den analytischen Teil gebe ich in Kapitel 6 eine Zusammenfassung der vorangegangenen Untersuchungen und versuche, anhand ihrer Auswertung Antworten auf die Fragestellungen zu finden, die mich seit spätestens 2014 in meinem Forschungsvorhaben geleitet haben. Nach zahlreichen Änderungen und Verfeinerungen der anfänglichen Fragestellungen gelangte ich 2014 zu den Fragen, die in dieser Arbeit diskutiert werden: 1. Wie identifizieren sich die Frauen in Bezug auf die Zeit der Schwangerschaft, auf Geburt und auf die nachgeburtliche Zeit? 2. Wie wird das Hilfspersonal indentifiziert und dargestellt, das den Frauen in diesen drei Phasen/Momenten zur Seite steht? 3. Wie werden die Kontexte der Geburtsvorbereitungsphase und der Geburt dargestellt? 4. In welchem Zusammenhang stehen diese Repräsentationen mit dem größeren konjunkturellen Rahmen, in dem sie stattfinden oder aus dem sie resultieren? 5. Inwieweit verschlimmert bzw. verringert sich auf der diskursiven Ebene das Problem der Gewalt unter der Geburt, wenn man den weiter gefassten Kontext berücksichtigt, in dem sie stattfindet? 
Stelle ich im darauffolgenden, letzten Kapitel meine Schlussbetrachtungen an, so können diese jedoch nicht als abschließend, sondern vielmehr als weiterführend gelten in der Erkenntnis, dass der Rahmen dieser Dissertation zwar begrenzt ist, nicht jedoch die Notwendigkeit, den Kampf für unsere Rechte fortzusetzen. 